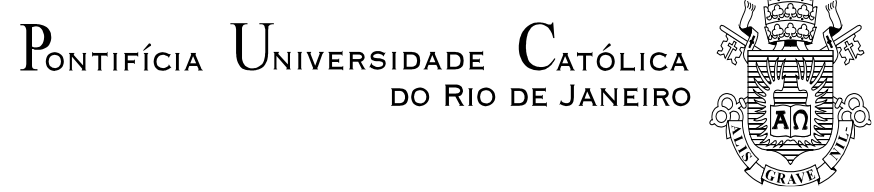

Carla Cristina de Souza

"Onde que a gente se encaixa aqui?": (re)construções de identidades de uma professora em formação no estágio de inglês para fins específicos sob a perspectiva da linguística sistêmico-funcional

Tese de Doutorado

Tese apresentada ao Programa de Pós-graduação em Estudos da Linguagem da PUC-Rio como requisito parcial para obtenção do grau de Doutor em Letras/Estudos da Linguagem

Orientadora: Profa. Adriana Nogueira Accioly Nóbrega 


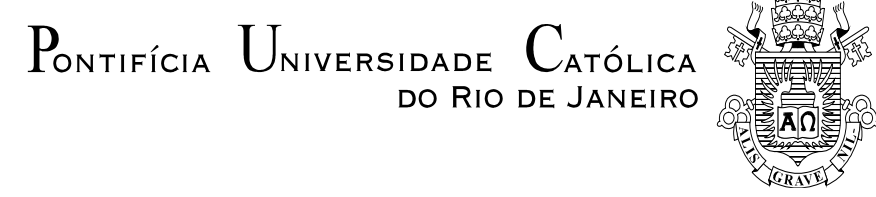

Carla Cristina de Souza

\title{
“ONDE QUE A GENTE SE ENCAIXA AQUI?": (re)construções de identidades de uma professora em formação no estágio de inglês para fins específicos sob a perspectiva da linguística sistêmico-funcional
}

\begin{abstract}
Tese apresentada como requisito parcial para obtenção do grau de Doutor pelo Programa de PósGraduação em Estudos da Linguagem da PUC-Rio. Aprovada pela Comissão Examinadora abaixo assinada.
\end{abstract}

Profa. Adriana Nogueira Accioly Nóbrega Orientadora e presidente Departamento de Letras - PUC-Rio

Profa. Inés Kayon de Miller Departamento de Letras - PUC-Rio

Profa. Liana de Andrade Biar Departamento de Letras - PUC-Rio

Prof. Orlando Vian Junior UNIFESP

Profa. Isabel Cristina Rangel Moraes Bezerra UERJ

Profa. Monah Winograd Coordenadora Setorial do Centro de Teologia

E Ciências Humanas - PUC-Rio

Rio de Janeiro, 14 de dezembro de 2018. 
Todos os direitos reservados. É proibida a reprodução total ou parcial do trabalho sem autorização da universidade, da autora e do orientador.

\section{Carla Cristina de Souza}

Graduou-se em Letras, com bacharelado e licenciatura em Português-Inglês na UFRJ em 2004. Cursou a especialização lato-sensu em Linguística Aplicada na UERJ em 2009. Concluiu o Mestrado em Linguística na UERJ em 2011. Dedica-se ao ensino da língua inglesa nos níveis médio técnico, pós-médio e graduação. Participa de projetos de pesquisa na área de Linguística Sistêmico-Funcional. Tem apresentado trabalhos em congressos nacionais e internacionais, enfocando suas áreas de interesse, que compreendem Linguística Aplicada, Inglês para Fins Específicos, Linguística Sistêmico-Funcional e Formação de Professores.

Ficha Catalográfica

Souza, Carla Cristina de

"Onde que a gente se encaixa aqui?": (re)construções de identidades de uma professora em formação no estágio de inglês para fins específicos sob a perspectiva da linguística sistêmico-funcional / Carla Cristina de Souza; orientadora: Adriana Nogueira Accioly Nóbrega. - 2018.

222 f.: il. color.; $30 \mathrm{~cm}$

Tese (doutorado) - Pontifícia Universidade Católica do Rio de Janeiro, Departamento de Letras, 2018.

Inclui referências bibliográficas.

1. Letras - Teses. 2. Linguística aplicada. 3. Identidades. 4. Linguística sistêmico-funcional 5. Sistema de avaliatividade. 6. Estágio supervisionado; 7. Comunidade de prática. 8. Inglês para fins específicos. I. Nóbrega, Adriana Nogueira Accioly. II. Pontifícia Universidade Católica do Rio de Janeiro. Departamento de Letras. III. Título. 
Para minha amada família, Wagner, Gustavo e Rodrigo. 


\section{Agradecimentos}

Aos professores que me acompanharam no IFRJ como estagiários, professores regentes e de Prática de Ensino, por todas as contribuições não só nesta pesquisa, mas também em minha formação docente;

Aos meus queridos amigos da equipe de Línguas Estrangeiras do IFRJ, pela afeição e parceria inestimáveis, por todas as aprendizagens conjuntas e pelo prazer de conviver com pessoas que tanto admiro;

À minha orientadora Adriana Nóbrega, acolhedora em todos os momentos dessa jornada, pela inspiração, paciência, carinho e motivação;

Aos colegas com quem cursei disciplinas no Doutorado e aos amigos do Grupo de Pesquisa de Análise Sistêmico Funcional e Avaliatividade no Discurso (ASFAD), pelas conversas, pelo conhecimento compartilhado e pelo afeto;

À PUC-Rio, pela concessão de bolsa de isenção;

O presente trabalho foi realizado com o apoio da Coordenação de Aperfeiçoamento de Pessoal de Nível Superior - Brasil (CAPES) Código de Financiamento 001.

Às minhas amigas Elza e Sabrina, pelas conversas e todo apoio ao longo dessa e de outras jornadas;

Aos meus amados pais, exemplos de perseverança, fé e amor incondicional, pelos ensinamentos e amparo constantes;

Aos meus filhos, Gustavo e Rodrigo, e ao meu marido Wagner, grandes amores da minha vida, aos quais dedico esta tese. Além de todo apoio, incentivo e compreensão, agradeço pelo carinho, pelas risadas e até pelas cantorias, assovios e o som do violão, aquela bagunça gostosa que me fazia dispersar da tensão do processo de escrita e acabava tornando tudo mais fácil;

A Deus, por tudo. 


\section{Resumo}

Souza, Carla Cristina de; Nóbrega, Adriana Nogueira Accioly (Orientadora). "Onde que a gente se encaixa aqui?": (re)construções de identidades de uma professora em formação no estágio de inglês para fins específicos sob a perspectiva da linguística sistêmico-funcional. Rio de Janeiro, 2018. 222 p. Tese de Doutorado - Departamento de Letras, Pontifícia Universidade Católica do Rio de Janeiro.

Este estudo tem por objetivo investigar as (re) construções identitárias de uma licencianda no estágio na comunidade de prática de Inglês para Fins Específicos (IFE) a qual pertenço, como parte da busca de entendimentos sobre esse contexto. Para tanto, os dados foram gerados ao longo do semestre que a estagiária compartilhou conosco e eles englobam participações orais e escritas, nas quais foram analisadas suas identidades, que parecem emergir de suas escolhas na linguagem para interpretar o que ela estava vivenciando durante o estágio. Seguindo uma abordagem qualitativo-interpretativista (ERICKSON, 1986; DENZIN; LINCOLN, 2006) e desenvolvida dentro da Linguística Aplicada (MOITA LOPES, 2006, 2013), esta pesquisa se baseia em uma perspectiva socioconstrucionista de identidades (MOITA LOPES, 2003; BUCHOLTZ; HALL, 2005) e sua relação com crenças (BARCELOS, 2006) e emoções (BARCELOS, 2012; ZEMBYLAS, 2004), em conjunção com o prisma da Linguística Sistêmico-Funcional (THOMPSON, 2014a; HALLIDAY; MATTHIESSEN, 2014; EGGINS, 2004; GOUVEIA, 2009) e do Sistema de Avaliatividade (MARTIN; WHITE, 2005; VIAN JR, 2009). A partir desse arcabouço teórico, as análises e discussões sugerem que há novas construções e reformulações significativas nas identidades da estagiária, que emergem discursivamente, principalmente dentro do domínio do afeto. Além disso, é possível interpretar que o estágio supervisionado e as experiências e interações na comunidade de prática de IFE foram essenciais nessas (re) construções, especialmente como professora, com identidades, crenças e emoções interconectadas. O processo de questionamento, análise e reflexão dessas identidades e sua relação 
complexa com crenças e emoções contribuiu para o desenvolvimento de entendimentos para nossa comunidade de prática, como também promoveu oportunidades de aprendizagem mútua e a curiosidade por outras questões, que podem nos motivar a continuar na pesquisa constante sobre esse contexto de forma mais dinâmica e inclusiva.

\section{Palavras-chave}

Linguística aplicada; identidades; linguística sistêmico-funcional; sistema de avaliatividade; estágio supervisionado; comunidade de prática; inglês para fins específicos. 


\section{Abstract}

Souza, Carla Cristina de; Nóbrega, Adriana Nogueira Accioly (Advisor). "Where do we fit in here?": (re)constructions of a student-teacher in the practicum in the community of practice of english for specific purposes from a systemic functional linguistics perspective. Rio de Janeiro, 2018. 222 p. Tese de Doutorado - Departamento de Letras, Pontifícia Universidade Católica do Rio de Janeiro.

The aim of this study is to investigate the identity (re) constructions of a student-teacher in the practicum in the community of practice of English for Specific Purposes (ESP) that I belong to as part of the search for understandings about our context. In order to accomplish such objective, data generated throughout the semester the student-teacher shared with us encompass oral and written participations in which the identities were analysed and they seemed to emerge from the choices in language to interpret what she was living during the practicum. This interpretativequalitative research (ERICKSON, 1986; DENZIN; LINCOLN, 2006) is in the area of Applied Linguistics (MOITA LOPES, 2006; 2013) and it is aligned with social constructionist theories of identity (MOITA LOPES, 2003; BUCHOLTZ; HALL, 2003, 2005), beliefs (BARCELOS, 2006) and emotions (BARCELOS, 2012; ZEMBYLAS, 2004). It is also in interface with the principles of Systemic Functional Linguistics (HALLIDAY, 1994; HALLIDAY; MATTHIESSEN, 2014) and the Appraisal System (MARTIN; WHITE, 2005; VIAN JR, 2009). Based on this theoretical framework, the analysis and discussions suggest that there are new constructions and significant reformulations in the student-teacher's identities, which emerge discursively, mainly within the domain of affect. In addition, it is possible to interpret that the practicum and the experiences and interactions in our community of practice of ESP were essential in her (re) constructions, especially as a teacher, and they include interconnected identities, beliefs and emotions. The process of questioning, analysing and reflecting on these identities and their complex relation to beliefs and emotions has contributed to the development of understandings for our community of practice. It also 
fostered opportunities for mutual learning and the curiosity for other inquiries that can motivate us to continue the constant research about this context in a more dynamic and inclusive way.

\section{Keywords}

Applied linguistics; identities; systemic functional linguistics; appraisal system; practicum; community of practice; english for specific purposes. 


\section{Sumário}

1. Introdução 15

2. Linguística aplicada. 20

2.1. A formação inicial de professores de línguas e o estágio supervisionado 35

2.1.1. A relação entre teoria e prática na formação de professores................23

2.1.2. O estágio supervisionado na formação docente............................... 27

2.2. A formação de professores de IFE .................................................... 29

2.2.1. Origens, características do IFE e seu desenvolvimento no Brasil ........30 30

2.2.1.1. Ampliando o conceito de necessidades em IFE............................... 32

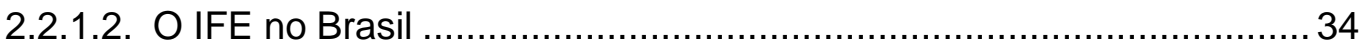

2.2.1.3. Os mitos que rondam o ensino de IFE no Brasil ............................... 38

2.2.2. A preparação do profissional de IFE ............................................ 40

3. Identidade: um processo em constante (re) construção ...................... 43

3.1. A concepção de identidades............................................................. 43

3.2. Identidades sob uma perspectiva sociocultural..................................... 45

3.3. A relação com o(s) outro(s) na construção de identidades .................... 49

3.3.1. Comunidades de prática .................................................................. 51

3.3.2. A construção de identidades profissionais docentes .......................... 53

3.4. Identidades, crenças e emoções ................................................... 57

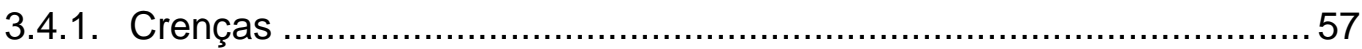

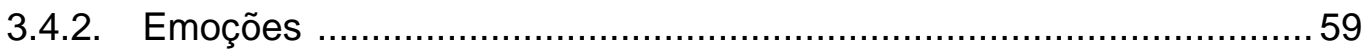

3.4.3. (Re)construções de identidades-crenças-emoções.............................61

4. A construção discursiva de identidades a partir de uma perspectiva

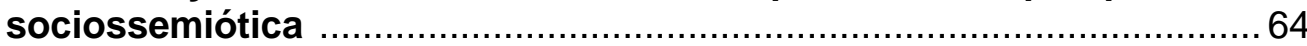

4.1. A representação das experiências da licencianda na oração: a

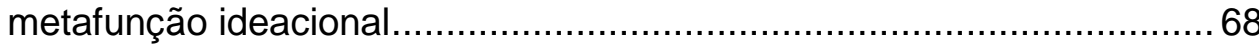

4.2. A negociação de significados na oração: a metafunção interpessoal ....71

4.3. O Sistema de Avaliatividade ................................................................ 73

5. Percurso metodológico e contextualização dos dados ......................... 80

5.1. Paradigma de pesquisa............................................................. 80

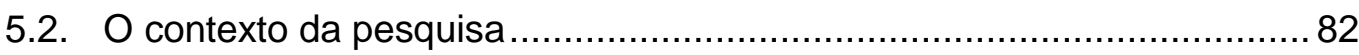

5.2.1. O instituto e as aulas de IFE em nossa comunidade de prática ...........82

5.2.2. O estágio em nossa comunidade de prática....................................... 86 


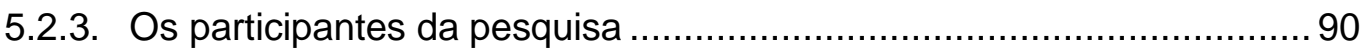

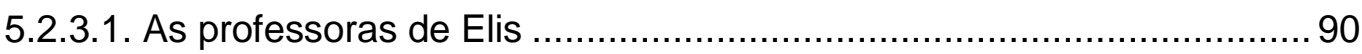

5.2.3.2. Os licenciandos que são contemplados nos dados .......................... 92

5.3. O convite para participar da pesquisa ................................................ 95

5.4. O processo de pesquisa e algumas mudanças no caminho ..................97

5.5. A geração dos dados e os procedimentos de análise .........................100

5.5.1. As respostas para as perguntas iniciais ........................................ 101

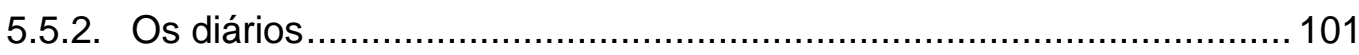

5.5.3. As conversas durante o estágio ............................................... 102

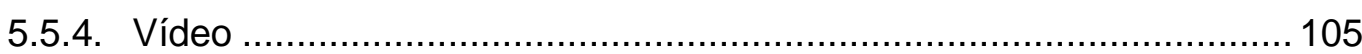

5.5.5. O memorial de estágio .................................................................... 105

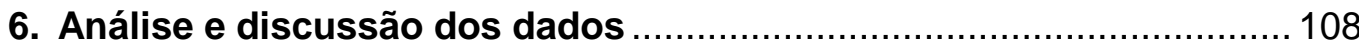

6.1. Algumas (re)construções identitárias de Elis no processo de

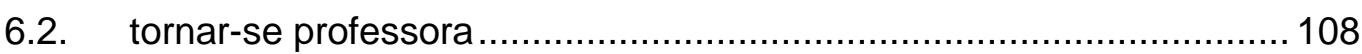

6.2.1. (Re)construções de Elis como estagiária ....................................... 109

6.2.2. (Re)construções de Elis como (não) futura professora....................... 134

6.2.3. (Re)construções de Elis como membro da nossa comunidade de

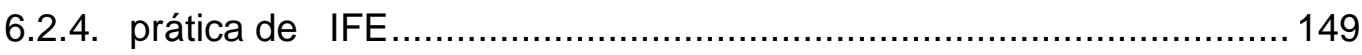

6.3. Retomando alguns dos entendimentos possíveis a partir das

6.4. análises dos dados .................................................................. 180

7. Algumas considerações e possíveis encaminhamentos .................... 186

8. Referências bibliográficas.............................................................. 191

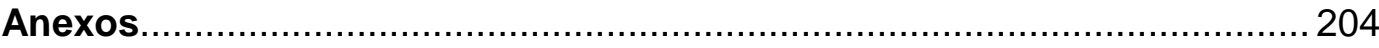

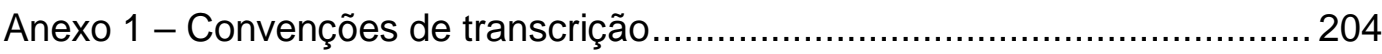

Anexo 2 - Perguntas e respostas iniciais.................................................. 205

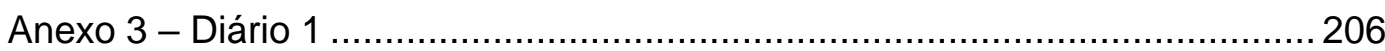

Anexo 4 - Diário sobre a regência ............................................................ 207

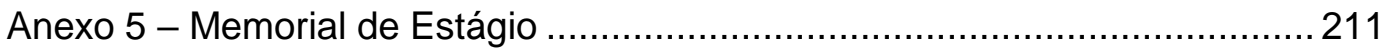

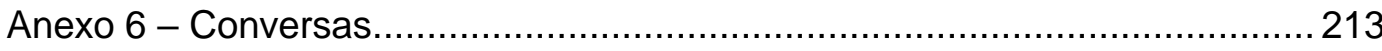

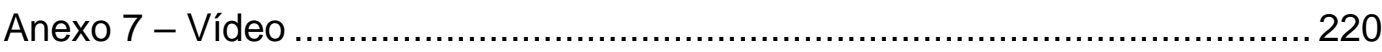

Anexo 8 - Autorização do Comitê de Ética em Pesquisa .............................. 221

Anexo 9 - Termo de Consentimento Livre e Esclarecido ................................. 222 


\section{Lista de figuras}

Figura 1 - Relações entre as áreas que fundamentam esta tese ............22

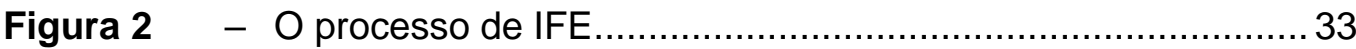

Figura 3 - Princípios fundamentais para o estudo de identidades .......... 46

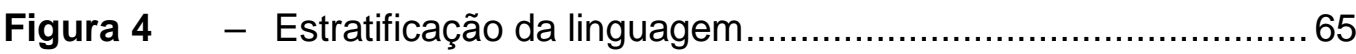

Figura 5 - Metafunções da linguagem.............................................6 67

Figura 6 - Inter-relação entre estratos da linguagem ...........................68

Figura 7 - Processos do Sistema de Transitividade ..............................69

Figura 8 - Relação entre modalidade e polaridade .............................. 72

Figura $9 \quad$ - Os subsistemas da Avaliatividade ..................................... 74

Figura 10 - Representação da relação entre afeto, apreciação e julgamento ...................................................................... 76

Figura 11 - Algumas subdivisões no sistema de Avaliatividade ................78

Figura 12 - Representação das identidades de Elis e sua inter-relação com crenças e emoções nos dados analisados.

Figura 13 - Algumas identidades de Elis que emergem dos dados 182 


\section{Lista de quadros}

Quadro 1 - Tipos de processo ……….......................................... 70

Quadro 2 - Funções discursivas .................................................... 71

Quadro 3 - Cursos oferecidos pelo IFRJ campus Rio de Janeiro ..............83

Quadro 4 - Dados selecionados para análise na etapa de qualificação....99

Quadro 5 - Dados analisados .......................................................... 101

Quadro 6 - Lista das conversas e seus excertos analisados ................. 104

Quadro 7 - Organização da análise ................................................... 107

Quadro 8 - Resumo de algumas das (re)construções identitárias de Elis como estagiária....................................................................... 131

Quadro 9 - Resumo das (re)construções identitárias de Elis como (não) futura professora ................................................................... 147

Quadro 10 - Resumo de algumas das (re)construções identitárias de Elis como membro da comunidade de prática de IFE.

Quadro 11 - Perspectivas sobre o estágio, o contexto de IFE e a escolha pela docência nos dados 


\section{Lista de abreviações}

CoTP - Coordenação Técnico Pedagógica

CT - Contraturno

DE - Direção de Ensino

IFE - Inglês para Fins Específicos

IFRJ - Instituto Federal de Educação Ciência e Tecnologia do Rio de Janeiro

LA - Linguística Aplicada

LSF - Linguística Sistêmico-Funcional

PMQ - Pós Médio de Química

TCLE - Termo de Consentimento Livre e Esclarecido

UFRJ - Universidade Federal do Rio de Janeiro 


\section{1 \\ Introdução}

Ainda que imperceptível ou difícil de ser expresso em palavras, a experiência de estar com o outro, ensinando e aprendendo, faz com que muito ocorra com cada um de nós.

(MORAES BEZERRA, 2011b, p. 94)

Além de ser um período de observação e prática para os futuros professores, o estágio supervisionado é "um espaço de interlocução mútua entre os formadores, estagiários e professores colaboradores" (GIMENEZ; PEREIRA, 2007, p. 97) gerando compartilhamentos que não se restringem apenas aos conhecimentos pedagógicos, mas que também podem compreender a constituição e a reelaboração de práticas, identidades, sentimentos e concepções. Com vistas a "criar inteligibilidades" (MOITA LOPES, 2006b, p. 85) sobre o contexto de estágio ${ }^{1}$ em uma comunidade de prática (LAVE, WENGER, 1991; KIELY, 2015) de Inglês para Fins Específicos (doravante IFE) do qual faço parte, o presente trabalho, que se insere na área de Linguística Aplicada (MOITA LOPES, 2006, 2009, 2013b), tenta 'expressar em palavras' um pouco do que tem 'ocorrido conosco' durante a nossa caminhada juntos e tem como foco as (re)construções identitárias de uma das estagiárias participantes desse processo, a quem chamarei de Elis ${ }^{2}$.

Acredito que estudar nossas interações no estágio de forma reflexiva e colaborativa pode contribuir para compreender melhor a nós mesmos, como nos sentimos, nossas crenças, práticas e contextos (MILLER, 2013). Assim, considero que trazer para reflexão e discussão as interpretações de Elis sobre suas vivências no estágio traçando conexões com suas (re)construções de identidades, que emergem na linguagem, podem criar oportunidades de aprendizado para todos os participantes em nosso contexto (dentre eles os estagiários, professores de Prática de Ensino e meus colegas docentes do instituto), colaborando para nossas próprias ressignificações como docentes em constante formação. Além disso, por se tratar de um estudo de caso, contextualmente situado, intransferível e de forma alguma generalizável, esta pesquisa pode instigar em nossa comunidade de prática (e nos leitores interessados) novos questionamentos,

\footnotetext{
${ }^{1}$ Este estudo foi desenvolvido no IFRJ, que também será chamado de instituto e escola técnica de forma intercambiável.

${ }^{2}$ Apresento Elis no capítulo 5 (seção 5.2.2), quando descrevo os participantes da pesquisa.
} 
reformulações e investigações, principalmente nas áreas de formação de professores e IFE.

Meu interesse no desenvolvimento desta pesquisa nasceu da conversa informal com professores recém-formados, estagiários e colegas de trabalho sobre as nossas vivências no estágio, da leitura de memoriais de estagiários e dos meus próprios questionamentos ao refletir sobre minhas experiências como estagiária, professora substituta de Prática de Ensino e, agora, como professora regente que acolhe estagiários. Ao participar dessas interações, pude perceber que existe uma tensão entre os estagiários, os professores que os recebem, e os professores de Prática de Ensino, o que pode dificultar a negociação de significados entre nós. Acredito que haja um conflito na forma como entendemos as práticas pedagógicas, o que é ser professor, nossos papeis e o que se espera do estágio. Essas diferentes perspectivas, que poderiam ser oportunidades para nossa união e fontes de questionamento e desenvolvimento mútuo, são comumente motivo de afastamento, gerando e fomentando identidades, crenças e emoções negativas quanto à docência, ao IFE e ao período de pré-serviço, que também criam a sensação de não-pertencimento, de 'não encaixe' nesse contexto (como exemplificado pela indagação de Elis que foi transcrita no título desta tese).

Além disso, ao receber estagiários no instituto, percebi muito receio dos licenciandos quanto ao IFE e à elaboração de materiais didáticos, aspecto importante no contexto em que esta pesquisa foi desenvolvida. O trabalho com essa abordagem parece ser dificultado pelo pouco conhecimento que os licenciandos têm da área e talvez também pelas crenças ligadas ao seu ensino. Essas são apenas algumas das questões que surgiram ao lançar o meu olhar para a interação entre agentes do processo de formação de professores, das quais emergem diferentes identidades, entrelaçadas a algumas de suas crenças e permeadas de emoções, e que, ao meu ver, precisam ser apresentadas para discussão e reflexão, como proposto aqui. Para tanto, parto do pressuposto de que as identidades são construídas e negociadas nas interações (MOITA LOPES, 2003) e que geram e sofrem influência das crenças (KUDIESS, 2005; BARCELOS; VIEIRA-ABRAHÃO, 2006; BARCELOS, 2007 e OLIVEIRA; BARCELOS, 2012) e emoções (ZEMBYLAS, 2004; REZENDE; COELHO, 2010). Com efeito, identidades, crenças e emoções se relacionam com as ações docentes, sofrem influências do contexto e podem ser reelaboradas nesse espaço.

Apesar de muitas pesquisas abordarem a construção de identidades docentes (CONCEIÇÃO, 2013; FABRÍCIO, 2011; MARCELO, 2009; dentre 
outras), as crenças de alunos (como em BARCELOS, 2004), de professores em geral (como em KUDIESS, 2005) ou do professor-aluno sobre o ensino de língua estrangeira e materna (como em BARCELOS, 2011; OLIVEIRA; BARCELOS, 2012), poucos trabalhos tratam das crenças sobre o estágio em si, muito menos no contexto de IFE. Outro aspecto pouco explorado é a relação entre identidades, crenças e emoções (BARCELOS, 2013 e 2017), que considero essencial para a compreensão do desenvolvimento pessoal e profissional docente e, consequentemente, para este estudo. Além disso, em estudos sobre o período de pré-serviço, são exíguos os trabalhos que mencionam a regência, apesar de ela figurar nos dados desta pesquisa como uma das maiores preocupações dos estagiários. Também quase nenhuma atenção é dada à preparação de professores para o ensino de IFE. Tais lacunas mostram uma necessidade premente de mais investigações que envolvam essas questões da formação docente, como proponho nesta tese.

Sabendo que as identidades são construídas no e pelo discurso, acredito que, por meio da análise da linguagem, seja possível observar como Elis se (re)elabora constantemente nas interações, sendo suas ações motivadas tanto por aspectos microssociais, como também por aspectos de natureza macrossocial (MOITA LOPES, 2013a). Por isso, proponho basear minha pesquisa no entrelaçamento de teorias que partem do contexto: a perspectiva sociossemiótica da Linguística Sistêmico-Funcional (THOMPSON, 2014a; HALLIDAY, 1994; HALLIDAY; MATTHIESSEN, 2014; EGGINS, 2004; GOUVEIA, 2009), doravante LSF, e do Sistema de Avaliatividade (MARTIN, 2000; MARTIN; WHITE, 2005; VIAN JR.; SOUZA; ALMEIDA, 2011), juntamente com pressupostos socioconstrucionistas de identidades (MOITA LOPES, 2003; BUCHOLTZ; HALL, 2005; FABRÍCIO, 2011) e de crenças (KUDIESS, 2005; BARCELOS, 2011; OLIVEIRA; BARCELOS, 2012), bem como o entendimento de emoções como aspectos, ao mesmo tempo, socialmente construídos e internos (ZEMBYLAS, 2004; 2005; REZENDE; COELHO, 2010).

Portanto, olharei para as práticas discursivas de Elis sabendo que são influenciadas por relações de poder e que os textos que as compõem "ao mesmo tempo criam formas de perceber e representar o mundo, relações e identidades" (MEURER, 2005, p. 91). Além disso, cumpre lembrar que as análises e a interpretações nesta tese são posicionados: derivam do meu olhar para esses dados e, portanto, são entendidos a partir dos contextos situacional e cultural em que me encontro, assim como são influenciados pelas minhas identidades em (trans)formação, constituídas também por minhas crenças e emoções. Estou 
ciente da natureza inseparável entre identidades, crenças e emoções e apenas escolhi o primeiro construto como ponto de partida neste estudo, mas registro que há conexões entre os três. Assim, inevitavelmente, a influência das crenças e emoções nas (re)construções de identidades de Elis estará presente a todo momento, contíguas, ainda que por vezes apenas evocadas, nas discussões sobre sua trajetória identitária durante seu estágio em IFE.

Elis participou assiduamente do estágio e da pesquisa, tornando possível acompanhar muitos momentos de reflexão e (inter)ação e, por isso, suas interpretações no decorrer do período de pré-serviço em nossa comunidade de prática de IFE foram escolhidas como foco para o desenvolvimento deste trabalho. Dos dados gerados, foram selecionados para a análise as respostas da estagiária para algumas questões antes de iniciar o estágio, duas entradas em diário por ela cedidas a mim, seu memorial de estágio, seu relato gravado em vídeo, bem como transcrições de excertos de cinco das conversas em que ela interagiu com outros estagiários e professores durante todo o período em que esteve em nossa escola. O objetivo desta pesquisa é buscar entendimentos sobre o estágio desenvolvido na comunidade de prática de IFE investigando as interpretações de uma licencianda sobre diferentes aspectos do período de pré-serviço nesse contexto e analisar a relação entre elas e suas (re)construções de identidades, considerando que essas últimas também são permeadas de crenças e emoções, dando ênfase ao seu processo para tornar-se professora. Com esse propósito, apresento as seguintes questões para reflexão:

1. Que identidades emergem nas escolhas lexicogramaticais e semânticas de Elis sobre o estágio em si, o nosso contexto específico (especialmente a abordagem de IFE e a participação em nossa comunidade de prática) e a docência? Como as interpretações de Elis se relacionam às suas (re)construções identitárias, principalmente quanto ao processo de tornarse professora?

2. Como as crenças e emoções de Elis se relacionam às suas identidades nesse processo? É possível observar reconstruções ao longo de sua caminhada no estágio?

3. Que entendimentos podem ser gerados a partir das reflexões sobre as discussões desenvolvidas e debatidas nesta pesquisa para nossa comunidade de prática? 
Esta tese está organizada em oito capítulos. O primeiro se configura nesta introdução. No capítulo 2, delineio o contexto teórico para o desenvolvimento da pesquisa, localizando-a dentro do campo de estudos da Linguística Aplicada, mais especificamente no encontro das áreas de formação de professores (na qual destaco o estágio e a área de inglês para fins específicos, (sendo este último parte do contexto no qual a pesquisa foi desenvolvida) e identidades. Os capítulos 3 e 4 continuam a descrever a arquitetura teórica que fundamenta esta investigação, explorando os principais aspectos quanto aos estudos sobre identidades pertinentes a esta pesquisa, com foco especial na formação de professores e explicando de que forma as análises serão conduzidas a partir da Linguística Sistêmico-Funcional, principalmente com base no Sistema de Avaliatividade. $O$ capítulo 5 discute a metodologia de pesquisa adotada, que se insere em um paradigma qualitativo-interpretativista, e traz o detalhamento do contexto. $\mathrm{O}$ capítulo 6 abarca a análise e a discussão dos dados e, no capítulo 7 , apresento algumas considerações sobre as reflexões feitas até 0 momento e sugiro possíveis encaminhamentos. Finalmente, o capítulo 8 traz as referências bibliográficas usadas e é seguido pelos Anexos, que consistem da Autorização do Comitê de Ética em Pesquisa, do Termo de Consentimento Livre e Esclarecido (TCLE) e dos dados utilizados no presente estudo. 


\section{2 \\ Linguística aplicada}

Como lidar com a incerteza instaurada? Fazendo uso dela para chegar à inovação, em uma
junção de participação e antecipação, que é o oposto da adaptação e da acomodação.
Tornando as perguntas mais importantes do que a busca de respostas.

(CELANI, 2009a, p. 21)

Motivada pelos questionamentos sempre emergentes em minha sala de aula de IFE, que agora compartilho também como ambiente de formação inicial de professores, concentro-me, nesta tese, na busca de entendimentos sobre meu contexto, como sugerido por Celani (2009a) na epígrafe. Para tanto, neste capítulo descrevo como esta pesquisa de doutorado fundamenta-se na Linguística Aplicada (LA), um campo que abarca o ensino de IFE, a construção de identidades e a formação de professores, que são as áreas-chave deste estudo.

Inicialmente sempre definida em contraposição à Linguística, de onde ela se originou, a Linguística Aplicada nasceu como uma disciplina orientada principalmente para os estudos sobre ensino de línguas estrangeiras (MENEZES et al., 2009), mas se ampliou vertiginosamente ao longo de sua trajetória. Hoje, trata-se de uma área totalmente independente e autônoma, altamente produtiva e, sob seu prisma, configuram-se os mais variados tópicos de investigação. Posso citar, como exemplo, a lista das áreas temáticas em discussão na 18ª . edição do Congresso Mundial da Associação Internacional de Linguística Aplicada ${ }^{3}$ (AILA), realizado no Rio de Janeiro em 2017, que mostra como os horizontes da LA se expandiram para abarcar cada vez mais os domínios em que a linguagem é usada.

Um dos motivos para essa transformação se deve ao fato de a LA ser uma área em diálogo cada vez maior e constante, em "estado de interação dinâmica" (CELANI, 1998, p. 132) com outros campos do conhecimento, que se debruça sobre as práticas discursivas nos mais diversos contextos. Certamente, ainda existem trabalhos em LA que permanecem muito atrelados às limitações disciplinares e à resolução de problemas (MOITA LOPES, 2013a; AMORIM, 2017). Entretanto, tomo aqui nesta pesquisa o mesmo posicionamento que Moita Lopes (2006a) e Celani (2004), que defendem a necessidade de as pesquisas em

\footnotetext{
${ }^{3}$ Foram trinta as áreas temáticas apresentadas no 18ํ. Congresso Mundial de Linguística Aplicada (AILA), sendo agrupadas nas seguintes linhas: Linguagem e Letramentos; Ensino e Aprendizagem de Línguas; Linguagem e Trabalho; Linguagem nas Sociedades; e Linguística Aplicada e Metodologia. Dentre os temas abordados, o presente trabalho integra as áreas de Formação de Professores e Linguagem e Identidades. Mais informações podem ser obtidas no caderno de resumos do AILA, disponível no endereço http://www.aila2017.com.br/images/ Book\%201-v3_Finalresumos.pdf
} 
LA seguirem um rumo inter/transdisciplinar, conjugando conhecimentos de outras esferas como a filosofia, a sociologia, a educação e a psicologia, dentre outras, e desbravando caminhos múltiplos nos âmbitos de uso da linguagem, visando criar inteligibilidades sobre as situações estudadas.

Nesse sentido, Moita Lopes (2006b) propõe repensar as formas de fazer pesquisa em LA, distinguindo, além da urgência de entendê-la como uma área híbrida e mestiça ${ }^{4}$, a qual o autor chama de INdisciplina (MOITA LOPES, 2006a; 2009), outras três características que a tornam mais pertinente à vida contemporânea. O segundo ponto salientado por Moita Lopes (2006b) é a premência por dissipar a contraposição teoria e prática, pesquisador e objeto ${ }^{5}$, a busca pela imparcialidade, como se a neutralidade fosse possível ou desejável. $\mathrm{Na}$ verdade, é essencial ao linguista aplicado, que busca fundamentalmente compreender melhor as práticas sociais nas quais a linguagem é central, "explodir" distanciamentos e integrar teoria e prática, o que pode ser feito usando "a prática como próprio palco de reflexões teóricas", como afirma Rajagopalan, em uma entrevista (apud SILVA; SANTOS; JUSIANA, 2011). O terceiro ponto levantado por Moita Lopes (2006b) reitera essa necessidade de proximidade, dando destaque aos sujeitos, social, histórica e culturalmente situados, com identidades heterogêneas, fluidas e fragmentadas. Segundo o autor, "conhecimento que não considera as vozes daqueles que vivem a prática social não pode dizer nada sobre ela" (MOITA LOPES, 2006b, p. 101). Além disso, como quarto e último tópico para discussão, Moita Lopes afirma ser imprescindível salientar as questões de ética e poder nas pesquisas em LA, já que é impossível relativizar todos os significados e temos o compromisso, como linguistas aplicados, de nos orientar por limites éticos.

Assim, além de procurar seguir esses quatro princípios que pautam uma LA contemporânea, esta pesquisa se alinha a uma visão de LA transgressiva (PENNYCOOK, 2006), empenhando-se na reflexividade, buscando novas perspectivas, principalmente os aspectos locais (MAKONI; MEINHOFF, 2006; RAJAGOPALAN, 2006), como as dúvidas, inseguranças e dificuldades cotidianas de uma estagiária sobre o período de pré-serviço, sobre a docência e as práticas de IFE, por vezes deixadas de lado, polemizando e problematizando o

\footnotetext{
${ }^{4}$ Esse é o primeiro ponto destacado por Moita Lopes (2006b).

${ }^{5}$ Essa visão dos participantes da pesquisa como 'objetos' de estudo, desumanizados e alheios ao processo de pesquisa, como criticado por Cavalcanti (2006), chama a atenção negativamente por estar em contradição aos princípios relativos à ética e poder (CAVALCANTI, 2006; FABRÍCIO, 2006; MOITA LOPES, 2006b). Esse procedimento extirpa completamente o indivíduo de seu contexto e o reduz a um mero informante ou fonte de dados, distanciando-se também das realidades vividas em prol de cientificidade, postura a ser evitada no presente estudo.
} 
conhecimento produzido. Assim, tomando a reflexividade e a ética como práticas imprescindíveis ou, como sugere Fabrício (2006, p.59), a desaprendizagem como possibilidade de conhecimento, sigo uma LA contemporânea que se apoia na interface de diferentes campos do conhecimento, nos "pontos de escape" (CAVALCANTI, 2006, p. 234), na "leveza de pensamento" (ROJO, 2006, p. 254), "defendendo a responsabilidade e a solidariedade para com o outro na vida social e em novas formas de conhecer" (MOITA LOPES, 2006b, p. 89), no meu caso, o acolhimento de alunos-professores e a construção do estágio docente no instituto.

Com o objetivo de gerar entendimentos sobre o meu contexto, integro, nesta pesquisa, as áreas de formação de professores de línguas, identidades, ensino de IFE e LSF, todos inseridos na LA neste estudo, como ilustrado na figura 1. A LA é representada pela maior esfera formada por muitos outras, o que busca demonstrar a enorme diversidade de áreas que a compõe. As outras quatro esferas em destaque à direita, pontos chave desta pesquisa, são representados como uma ampliação de parte da esfera da LA e estão ligadas entre si por linhas pontilhadas, sugerindo algumas das interconexões que podem ser feitas entre elas. No entanto, as linhas entrecortadas buscam ilustrar que essas áreas não são fechadas ou presas umas às outras e podem ser estudadas sob outros âmbitos, diferentes do da LA. Os estudos em LSF, por exemplo, não são necessariamente desenvolvidos em LA como na presente pesquisa.

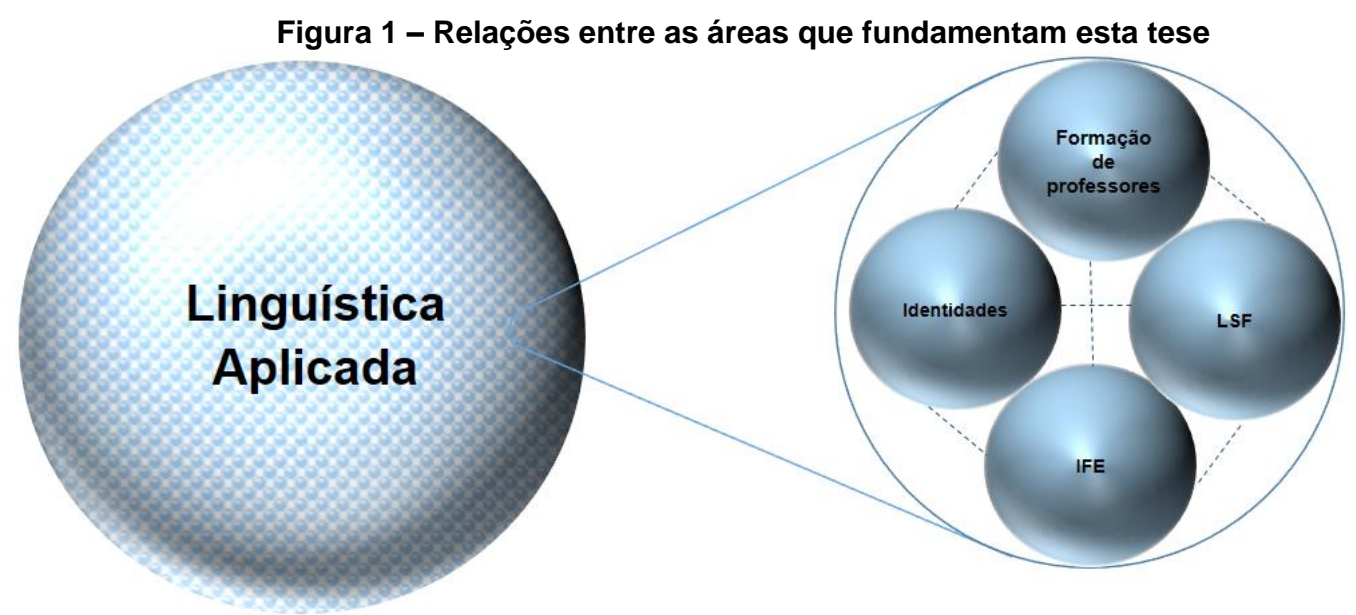

Fonte: Figura de minha autoria

Nas próximas subseções, discuto a formação de professores de línguas (tema central que permeia os estudos nos quais esta pesquisa se baseia), principalmente o papel do estágio supervisionado e a relação entre teoria e prática para o aluno-professor (na subseção 2.1), para então descrever algumas peculiaridades da formação docente para o ensino de IFE. Para tanto, na subseção 2. 2, apresento como se desenvolveu a abordagem de IFE (o que foi 
atrelado à preocupação constante com a formação docente na área, principalmente no Brasil), suas principais características, os mitos a ela ligados e a preparação do professor.

\section{1}

\section{A formação inicial de professores de línguas e o estágio supervisionado}

A formação de professores é um "processo altamente complexo, pontuado por incertezas", (SALIÉS, 2015, p. 11) que envolve as diversas experiências do educador, dentre as quais está o ensino universitário e a convivência na(s) escola(s) onde acontece $(\mathrm{m})$ o estágio supervisionado. Entretanto, no Brasil, segundo Vieira-Abrahão (2016), é relativamente recente a percepção de que teoria e prática devem se desenvolver de forma integrada. Essa discussão sobre teoria versus prática aparece muitas vezes nos dados gerados e ela é retomada a seguir.

\subsection{1.}

\section{A relação entre teoria e prática na formação de professores}

Inicialmente, o esquema seguido para organização entre as disciplinas ficou conhecido como $3+1$ : nos três primeiros anos, os licenciandos aprendiam a teoria, enquanto no último, que era reservado ao estágio, eles teriam "a oportunidade de aplicar os conhecimentos adquiridos" (Vieira-Abrahão, 2016, p. 190). Essa estruturação foi modificada ao longo do tempo e hoje, de acordo com as Diretrizes Curriculares Nacionais para Formação de Professores, o estágio deve estar "articulado ao restante do curso", ao passo que a prática deve estar "no interior das áreas ou das disciplinas que constituírem os componentes curriculares de formação", deixando de ficar a cargo somente das disciplinas pedagógicas, e ela "deverá estar presente desde o início do curso e permear toda a formação" (BRASIL, 2002, p. 8). A lacuna entre teoria e prática ainda está muito presente e arraigada na sociedade, mas a mudança nas diretrizes reflete um movimento em prol da ressignificação do lugar do estágio e da prática (NASCIMENTO, 2016), mesmo sabendo que existem diferentes perspectivas quanto à formação de professores.

A esse respeito, Bomfim e Conceição (2014), com base em uma vasta pesquisa, destacam três modelos comuns mencionados tanto por autores na área 
de educação geral como de Linguística Aplicada como paradigmas de formação docente: a) a formação artesanal, cujo foco é a prática, de forma que a profissão é aprendida por meio da observação e imitação de um mestre mais experiente, responsável por desenvolver no seu aprendiz aptidões, habilidades e sua capacidade inata; b) a formação tecnicista, fortemente pautada na aplicação da ciência sobre aquisição e treinamento de técnicas específicas, que devem ser passadas aos docentes no início de suas carreiras; e c) a formação reflexiva, que tem como cerne a ideia de que a construção do conhecimento sobre a profissão docente é aprendida pela reflexão na e sobre a prática, mediante a análise e interpretação das experiências do dia-a-dia, no contexto.

Em meu entendimento, existem certas restrições quanto aos três modelos, principalmente no que concerne a percepção de teoria e prática como desconectadas e também quando desconsideram a trama social complexa que permeia o âmbito educacional. O primeiro modelo incorre no equívoco de que a automatização e imitação de práticas sem qualquer base teórica ou reflexão sobre as mesmas preparariam o professor para o seu ofício. Já o modelo tecnicista, que há muitos anos também tem sido alvo de críticas (SCHÖN, 2000; LEFFA, 2001; ZEICHNER, 2008; entre outros), se apoia exclusivamente na teoria e considera o professor como mero instrumento de transmissão de saberes que especialistas preestabeleceram como diretrizes a se seguir, sem ter necessariamente relação com o contexto vivenciado ou considerar o profissional como capaz de construir entendimentos a partir de sua prática.

Por sua vez, dependendo de como se segue o modelo de formação reflexiva, pode-se preconizar a responsabilidade do próprio professor na produção do conhecimento docente, quando se considera que ele deve "entender as razões e racionalidades associadas com as diferentes práticas" e "tomar decisões sábias sobre o que fazer" (ZEICHNER, 2008, p. 536). Esse preceito também precisa ser ponderado, pois pode se orientar excessivamente pela prática (PIMENTA, 2002) e acabar por delegar um fardo, difícil de sustentar, ao professor, de forma que ele se sinta responsável pela resolução de problemas em sua sala de aula (SERRÃO, 2002).

Os modelos mencionados coexistem, mas o paradigma reflexivo é o mais amplamente seguido nos dias de hoje (SANTOS, 2010; BOMFIM; CONCEIÇÃO, 2014). Contudo, o vasto interesse pelo tema formação de professores ${ }^{6}$, tem

\footnotetext{
${ }^{6}$ Assim como podemos observar nos vários trabalhos apresentados em eventos nacionais e internacionais, bem como na publicação de livros, capítulos, trabalhos de pós-graduação e periódicos de Linguística Aplicada e outras áreas. Um exemplo é o Congresso Latino-Americano de Formação de Professores de Línguas (CLAFPL), evento que teve sua sexta edição em outubro de
} 
gerado mudanças na própria formação docente, tornando possível vislumbrar uma tendência cada vez maior em direção às "noções de educação, formação, trabalho e desenvolvimento profissional"; à "criticidade e a ética"; e à "pedagogia investigativa e inclusiva" visando a integração dos colaboradores, envolvendo-os ativamente na pesquisa sobre o seu próprio contexto (MILLER, 2013, p.100). A presente pesquisa se sintoniza com essa tendência, procurando não se prender a modelos, resolução de problemas ou dicotomias como teoria versus prática, mas buscando entendimentos locais, investigando "o que se faz, a experiência que se vive e a qualidade de vida gerada a partir da relação interpessoal" construída pelos participantes (MORAES BEZERRA, 2012, p. 60).

Considero também que a formação docente abarca diversas experiências educacionais e se estende por toda a carreira do professor (ALMEIDA FILHO, 2006), que fatores contextuais, observáveis e mentais (TUROLO-SILVA, 2014), políticos, sociais, históricos e culturais (LEFFA, 2001; MATEUS, 2006) influenciam as interações em sala de aula e o fazer docente, bem como concebo ambas teoria e prática essenciais e indissociáveis (VIEIRA-ABRAHÃO, 2002). Além disso, creio que tanto o curso de licenciatura quanto o estágio supervisionado são essenciais para a formação docente (QUADROS-ZAMBONI, 2015; VIEIRA-ABRAHÃO, 2007) e para o processo de (re)construção de suas identidades e que deveria haver uma maior integração entre essas duas esferas.

Portanto, concordo com Vieira-Abrahão (2007) quanto à importância do envolvimento e planejamento colaborativo entre universidade e escola. Destaco aqui que é imperativo que haja a negociação de significados e a construção conjunta do estágio ao invés de simplesmente ocorrer a submissão dos participantes da escola ao escrutínio e avaliação a partir de parâmetros estabelecidos pela universidade. O estagiário, o professor que o recebe na escola e o supervisor da universidade deveriam trabalhar em parceria, se empenhando na busca de caminhos para um estágio mais efetivo (LUDKE, 2013).

Do mesmo modo que Reichmann (2014), ressalto que os professores regentes têm papel de grande importância na constituição identitária dos estagiários, como também corroboro a perspectiva sociocultural de Johnson e Golombek (2016) quanto à formação docente: todos os participantes trazem conhecimentos experienciais e prévios, que podem se relacionar dialeticamente com saberes teóricos e promover a coconstrução de conceitos nas interações

2016 em Londrina e contou com mais de setecentos trabalhos, o que mostra a quantidade crescente de pesquisas na área de formação de professores. O caderno de resumos pode ser acessado pelo endereço http://www.viclafpl.com.br/pt/programacao/caderno-de-resumos/. 
entre esses professores. Assim, seguindo esse pensamento, entendo que ambos professores regentes e professores de Prática de Ensino são igualmente professores formadores e "co-responsáveis pela educação inicial" dos estagiários (MORAES BEZERRA, 2006, p. 731) e que eles, assim como os licenciandos, estão em formação no estágio supervisionado e podem colaborar para o enriquecimento pessoal e profissional de seus pares.

Tal afirmação diverge do ponto de vista desenvolvido no artigo de Ferreira (2016, p.162), que, apesar de admitir que "a figura do professor regente" tem "sua cota de participação na formação do estagiário", enaltece o papel do professor da universidade, referindo-se a ele como o único formador, ao mesmo tempo que reforça a concepção de que o professor da escola tem pouco a compartilhar, ao citar, por exemplo, "falta de maturidade" e "carência de conhecimentos teóricos suficientes e atualizados que lhe ofereçam base para discussões" como alguns dos motivos pelos quais a prática reflexiva envolvendo esses professores não "ocorre de maneira tão significativa". Acredito que esse tipo de conclusão fomenta o distanciamento entre universidade e escola e desconsidera que todos os participantes - alunos, licenciandos, professores regentes e da universidade - têm muito a colaborar na interação. Logo, não há razões para perpetuar os privilégios quanto aos conhecimentos advindos da universidade em detrimento dos da escola. Como dito anteriormente, todos ensinam e todos aprendem, posto que, como explica Liberali (2010, p. 74), o que cada um traz é riquíssimo, e tal profusão,

\begin{abstract}
assim como a necessidade de ampliação do universo de suas experiências para tornar possível um maior acúmulo de elementos da realidade e chances de combinações diversas e inovadoras dessas experiências, permite ampliar os significados compartilhados.
\end{abstract}

Nos dados gerados inicialmente para esta pesquisa, esse embate entre universidade e escola surge algumas vezes nas falas dos licenciandos participantes (que são aqui transcritas entre aspas), nas quais eles questionam o porquê dessa dicotomia e algumas crenças que eles tinham a esse respeito antes de começar o estágio, tais como de que: 1. não há compatibilidade entre essas duas esferas, pois "na teoria, tudo é muito bonito, mas na prática, a escola é um inferno"; 2. o saber teórico está conectado às disciplinas da graduação, principalmente à Prática de Ensino, responsável por ensinar os futuros professores a lecionar (como também observa CASTRO, 2009); 3. o papel dos estagiários é de observadores e avaliadores da prática no estágio em comparação à teoria aprendida na universidade; 4. o estagiário será visto como alguém "não 
querido, um alienígena" pelos professores regentes; 5. no estágio devem "ver o que não se deve fazer"; 6 . na escola de estágio, os licenciandos podem "ter uma noção dos tipos de problemas" que eles terão "que enfrentar no futuro" e "começar a pensar em como aplicar o que aprenderam para resolvê-los"; e 7. "é impossível ensinar inglês na escola", isso "só se aprende em cursinho" porque na escola, "o professor não está capacitado" a ensinar inglês para o aluno; dentre outras.

Por outro lado, alguns professores também se sentem apreensivos quanto à recepção de estagiários em suas salas e, assim como os estagiários, também expressam um conjunto de crenças que fazem parte da constituição de identidades/emoções, que parecem acentuar o afastamento entre esses dois espaços quando não há diálogo. Logo, essas concepções negativas partem dos dois lados (MELLO, 2010). Por isso, há a necessidade de um trabalho conjunto para compreender os discursos que permeiam o estágio e de talvez desmistificar e/ou tentar atenuar essas concepções que geram desconfiança e desunião de ambas as direções, prejudicando a formação desses professores. Precisamos de uma "construção dialógica de saberes, a partir do desenvolvimento de pontes" e do diálogo entre "todos os sujeitos envolvidos" (REIS; SANTOS, 2015, p. 19).

Nesse sentido, com vistas a trazer uma contribuição para a área de formação de professores dentro da Linguística Aplicada, a geração inicial dos dados para esta pesquisa foi feita a partir de diversas interações entre professores formadores e estagiários em diferentes momentos ao longo do estágio e esta tese se debruça sobre as trajetórias identitárias de uma das licenciandas, aqui chamada de Elis, durante esse período, compostas também por crenças e emoções, analisando os discursos que permeiam as interações das quais ela participa e buscando entendimentos sobre esse processo dentro do contexto de IFE. No entanto, primeiramente é necessário entender como se configura o estágio.

\subsection{2 \\ O estágio supervisionado na formação docente}

Pelo Parecer CNE/CP no 28/2001, ficaram estabelecidas 400 horas de práticas de ensino, vivenciadas ao longo do curso, 1800 horas para os conteúdos curriculares, 200 horas de atividades acadêmico-científico-culturais, além de 400 horas de estágio supervisionado, formando um total de, no mínimo, 2800 horas a serem realizadas em um prazo igual ou superior a 3 anos de formação. As 400 
horas de estágio podem ser distribuídas em diferentes escolas e níveis, como é o caso do que acontece no contexto descrito nesta pesquisa: apenas 120 dessas horas são cumpridas junto à equipe de IFE no ensino médio. O restante deve contemplar outros níveis e escolas, bem como o acompanhamento de aulas de língua portuguesa, pois os licenciandos serão formados com dupla habilitação.

Apesar de o estágio supervisionado ser uma exigência de todos os cursos de licenciatura, não há especificações sobre como conduzi-lo, tal como mencionam Bueno (2009), Valsechi (2016) e Dias (2016), fazendo com que ele seja desenvolvido, principalmente, conforme uma das seguintes perspectivas: de estágio como observação e reprodução da prática, como instrumentalização técnica ou como pesquisa (PIMENTA; LIMA, 2012). Pode-se perceber que essa divisão se relaciona diretamente aos três modelos de formação docente brevemente descritos nesta seção.

Pimenta e Lima (2012) consideram que o estágio tem papel central nos cursos de formação de professores, sendo um momento ótimo para "a construção de identidades, dos saberes e das posturas específicas ao exercício profissional docente". As autoras também afirmam que é imprescindível que o estágio seja desenvolvido "com e como pesquisa" (PIMENTA; LIMA, 2012, p. 61 e 79), criando a oportunidade para que os licenciandos ampliem a compreensão das situações vivenciadas e observadas nas escolas, nos sistemas de ensino e nas demais situações a partir de propostas dos professores orientadores para a elaboração de projetos de pesquisa durante ou após o período de pré-serviço. A partir dessa premissa, Dias (2016) diz que o estágio integra as etapas de observação, problematização, investigação, análise e intervenção, sendo o professor formador responsável por "orientar os professores iniciantes de modo que esses últimos tenham clareza para agir e intenção de intervir e (re)configurar seu trabalho" (ibid., p. 130).

Embora eu concorde com a necessidade premente de uma postura investigativa quanto à sala de aula, questiono esse direcionamento interventivo, que parece partir da leitura de que sempre há muito a mudar, de que a mudança é irrefutavelmente imprescindível e de que os saberes da universidade, as teorias, aprendidas pelo estagiário na graduação, serão aplicadas na escola. Reitero que uma fase inicial de observação é importante, mas, ao invés de seguir o esquema 'olhar, avaliar, achar um problema, analisar e apontar respostas', que parece estar atrelado à proposta de Dias (2016), acredito que essa observação deve se tornar, aos poucos, participação ativa, envolvimento na prática, engajamento nas 
atividades do estágio e negociação de saberes entre os participantes desse contexto.

Assim, em uma outra visada de estágio 'com e como pesquisa' para todos os professores engajados, a 'postura investigativa' se mantêm, porém, o propósito não é apontar falhas e produzir soluções, mas considerar os resultados como processo, a fim de que tenham "maior relevância intrínseca para as pessoas envolvidas do que para sua produtividade ou eficiência profissional" (MILLER, 2013, p.112). Considero, portanto, que o envolvimento em pesquisa no estágio não é só para os licenciandos, mas todos os professores, preferencialmente integrados em um processo de pesquisa reflexiva e inclusiva, no qual se preze a agência dos participantes e a riqueza dos compartilhamentos dessas investigações conjuntas. O objetivo é realmente procurar entender, participar, analisar junto, escutar uns aos outros, colaborar, coconstruir conhecimentos e, ao mesmo tempo, (re)formular a si mesmos. Desse modo, creio que o estágio supervisionado tem função crucial na constituição de identidades, tema do próximo capítulo. Antes, porém, apresento a base teórica sobre o contexto estudado, a formação de professores para o ensino de IFE, descrevendo brevemente a origem e algumas características dessa abordagem e o que se espera do profissional de IFE.

\section{2}

\section{A formação de professores de IFE}

Uma das perguntas que os estagiários me fazem com mais frequência é "Qual a formação do professor para dar aulas de IFE?", mas a resposta à essa questão não é nada simples pois requer certo conhecimento sobre a abordagem. Muitos professores com experiência em cursos particulares de inglês e escolas de ensino fundamental, mas que não tiveram contato com inglês para fins específicos, se sentem aflitos nas primeiras semanas trabalhando com IFE por falta de "preparação e vivência" na formação inicial (CELANI, 2009b, p. 9), como aconteceu comigo e com os estagiários que recebemos. No estágio em nossa comunidade de prática, percebemos a necessidade de debater textos sobre a abordagem e criar espaços para discutir expectativas, crenças e medos que os estagiários traziam. Para isso, apresentamos como se desenvolveu a abordagem e suas principais características, bem como debatemos algumas das crenças 
sobre o ensino de IFE, aspectos importantes para entender o contexto desta pesquisa e que serão abordados na próxima subseção.

\subsection{1 \\ Origens, características do IFE e seu desenvolvimento no Brasil}

Segundo Hutchinson e Waters (1987, p. 6-8), a demanda pelo ensino de IFE ganhou força depois da Segunda Guerra Mundial devido a três fatores principais. O primeiro deles foi a grande expansão nos campos científico, técnico e econômico, que levou à busca de uma língua por meio da qual trocas de conhecimentos e produtos pudessem ser feitas. Além disso, houve uma revolução na área da Linguística, que mudou o foco para pesquisas sobre a forma pela qual a comunicação realmente acontece, nas situações de uso, ao invés de se concentrar apenas na definição e descrição de regras. Na mesma época, observou-se o desenvolvimento da Psicologia Educacional, que passou a enfatizar a importância de se considerar o aluno, suas demandas e formas de motivá-lo para que a aprendizagem ocorra.

Ao longo dos anos, o IFE se transformou, sendo possível identificar diferentes tendências em seu desenvolvimento. Hutchinson e Waters (1987, p. 9) classificam essas tendências como "cinco fases principais", que representam um panorama geral, já que seu desenvolvimento tem ocorrido de formas e velocidades diversas em diferentes lugares do mundo. Segundo os autores (HUTCHINSON; WATERS,1987), na primeira fase, ocorreu a análise do registro, cujo foco central voltava-se à descrição de itens lexicais e gramaticais de textos, principalmente escritos (JOHNS, 2013, p.7), operando no nível da frase. Entretanto, como constatado por Swales (1985, p. 59), tal perspectiva se mostrou pouco eficiente para alcançar os objetivos traçados e foi, aos poucos, substituída pela análise retórica, campo em emergência na época. Nesta segunda fase, buscava-se entender como as frases se combinavam para produzir significados (HUTCHINSON; WATERS,1987, p.11). Visava-se, assim, identificar como os textos se organizam, que padrões existiam e como isso poderia ser linguisticamente marcado a fim de embasar o programa dos cursos. Entre outras contribuições desta fase estão as consultas a especialistas informantes da área específica, bem como análises retóricas distinguindo diferentes tipos de textos (SELINKER, 1988 apud JOHNS, 2013, p.8).

$\mathrm{Na}$ terceira fase, denominada análise das necessidades, o ponto de partida foi modificado, passando a ser a identificação da situação-alvo de uso da língua para a qual o aluno tem que se preparar, mas a abordagem continuou restrita à 
análise superficial dessas necessidades e de características linguísticas para elaborar o programa do curso. Somente na quarta fase o aluno realmente começa a tomar o lugar central das pesquisas, cujo enfoque passa a ser as estratégias ou habilidades que podem ajudá-lo a interagir com os textos. Esta preocupação se amplia na quinta fase, centrada nos meios pelos quais a aprendizagem de línguas ocorre (DUDLEY-EVANS; ST JOHN, 1998, p. 27), contemplando o fato de que existem diferentes formas de aprender e que cada indivíduo tem suas particularidades quanto a esse processo. Portanto, as três primeiras fases se concentram na lingua(gem) e as duas outras se voltam para o aluno, sendo as cinco essenciais ao se considerar o que envolve o conceito de necessidades.

Essas fases principais destacadas por Hutchinson e Waters (1987), as quais prefiro chamar de tendências, mostram como o IFE se renova a partir da interlocução entre teoria e prática: os praticantes de IFE estão necessariamente envolvidos em pesquisa quanto ao ensino-aprendizagem, sobre o seu contexto, seu fazer e as necessidades, que também estão em constante transformação. Portanto, como dito anteriormente, essas 'fases' não são estanques ou acontecem da mesma forma em diferentes localizações e, de forma alguma, são as únicas mudanças ocorridas no desenvolvimento do IFE. No entanto, é importante citá-las aqui porque certas crenças $/$ mitos $^{7}$ quanto à abordagem no Brasil advém do desconhecimento dessa natureza mutável do IFE e da superação de algumas tendências conforme as necessidades no contexto brasileiro (RAMOS, 2008), criando alguns mitos, como explicado na subseção 2.1.3 desta tese.

Assim, o IFE não é um produto, mas uma abordagem de ensino de línguas na qual todas as decisões sobre conteúdo e metodologia são baseadas nas razões de aprender dos alunos (HUTCHINSON; WATERS,1987, p. 19). $\mathrm{Na}$ verdade, considero que a busca por atender à essa e outras premissas que listo a seguir é o que diferencia o IFE do inglês geral. Primeiramente, as necessidades, que devem ser revisitadas, pesquisadas, reanalisadas e repensadas a todo tempo, são o cerne de todo o trabalho com IFE. Além disso, o ensino deve englobar os conteúdos das profissões e/ou disciplinas a que serve, ter objetivos claros, centrar-se na língua, habilidades, discurso e gêneros apropriados a estas atividades (DUDLEY-EVANS; ST. JOHN,1998) e tratar o aluno como parceiro no desenvolvimento de sua própria aprendizagem (RAMOS, 2005), já que seu conhecimento prévio bem como suas experiências são essenciais nesta

\footnotetext{
${ }^{7} \mathrm{Em}$ todos os textos pesquisados que se referem aos mitos quanto à abordagem de IFE (como RAMOS, 2005; 2009; BELMONTE; ROSSINI, 2015), a palavra mito é utilizada no sentido 'crenças comuns que não tem fundamento'.
} 
perspectiva. A própria relação professor-aluno é outra se comparada ao inglês geral, posto que o conhecimento é compartilhado entre eles colaborativamente (VIAN JR., 2015). Como as definições sobre conteúdos, materiais didáticos e metodologias são pautadas no contexto, nos alunos e nas razões para aprender, é claro que as necessidades em IFE vão se transformando, fazendo com que o seu próprio conceito careça de ampliação, o que é discutido a seguir.

\title{
2.2.1.1
}

\section{Ampliando o conceito de necessidades em IFE}

Parte da análise das necessidades consiste no levantamento inicial das características da situação usando diversos recursos como geração de dados por meio de questionários, entrevistas, observação, discussão, conversas e consultas a alunos, professores, bem como a outros profissionais da área específica e análise de textos autênticos escritos e falados, dentre outros. Entretanto, devemos lembrar que no centro de todo o processo está o aluno, e que o primeiro passo, como descrito por Dudley Evans e St. John (1998, p. 126) é conhecer esse aprendi $z^{8}$ :

\begin{abstract}
Primeiramente, a análise de necessidades objetiva conhecer os alunos como pessoas, como usuários e estudantes da língua. Em segundo lugar, o estudo da análise de necessidades também visa conhecer como o aprendizado de língua e habilidades pode ser maximizado para um determinado grupo de aprendizes. Em terceiro, o estudo da análise de necessidades busca saber sobre as situações alvo e o ambiente de aprendizado para que as informações possam ser devidamente interpretadas $^{9}$
\end{abstract}

Portanto, a análise de necessidades em si não é tão simples e demanda mais do que identificar as características linguísticas da situação-alvo, que englobam o que aprendiz deve saber para atuar na situação-alvo de forma eficiente e suas lacunas (que são a distância entre o que ele já sabe e o que deve saber), somadas ao que ele quer ou acha que precisa aprender (HUTCHINSON; WATERS,1987).

É preciso também conhecer a situação de aprendizagem, informações específicas sobre local, participantes, objetivos, estilos de aprendizagem, dentre outros fatores (ibid.). Além das necessidades da situação-alvo e de aprendizagem

\footnotetext{
${ }^{8}$ Todas as traduções nesta pesquisa foram feitas de forma livre por mim.

9 No original: First, needs analysis aims to know learners as people, as language users and as language learners. Second, needs analysis study also aims to know how language learning and skills learning can be maximized for a given learner group. Third, needs analysis study aims to know the target situations and learning environment so that data can appropriately be interpreted.
} 
destacadas por Hutchinson e Waters (1987, p.53 e 54), Dudley-Evans e St. John (1998) apresentam a análise da situação atual (o que os aprendizes já sabem da língua alvo, as habilidades e experiências de aprendizagem, bem como seus pontos fortes e fracos em relação à linguagem) e a análise do meio como essenciais. Ou seja, devemos ser mais abertos, flexíveis e sensíveis ao contexto, como disse Ann Jonhs aos especialistas de IFE em entrevista ao International Journal of Language Studies na publicação entitulada English for Specific Purposes: The state of the art (JOHNS, 2015).

Pesquisar e questionar sempre: esse deve ser o princípio a se seguir por todos que trabalham com IFE. Os praticantes dessa abordagem devem estar continuamente investigando o contexto e sua prática em relação direta com a teoria que a embasa, revendo a análise das necessidades, o design do curso, o ensino-aprendizagem, o processo como um todo e a sua avaliação de forma continua e interligada, como representado na figura 2, elaborada e adaptada a partir da junção de duas ilustrações de Dudley-Evans e St. John (1998, p. 121 e 125). Essa figura busca organizar visualmente os pontos aqui apresentados, mas alterei o traço constante das imagens originais por um tracejado que sugere fluidez e abertura, pois considero que o processo de IFE não é estático ou fechado. A análise das necessidades, por exemplo, não se limita apenas aos tópicos apresentados por Hutchinson e Waters (1987) e Dudley-Evans e St. John (1998) e eles não são estanques. Além disso, o levantamento das necessidades não se restringe ao início do curso (VIAN JR, 2008), mas deve ser um exercício constante, retroalimentando e recebendo informações de todos os outros estágios do processo.

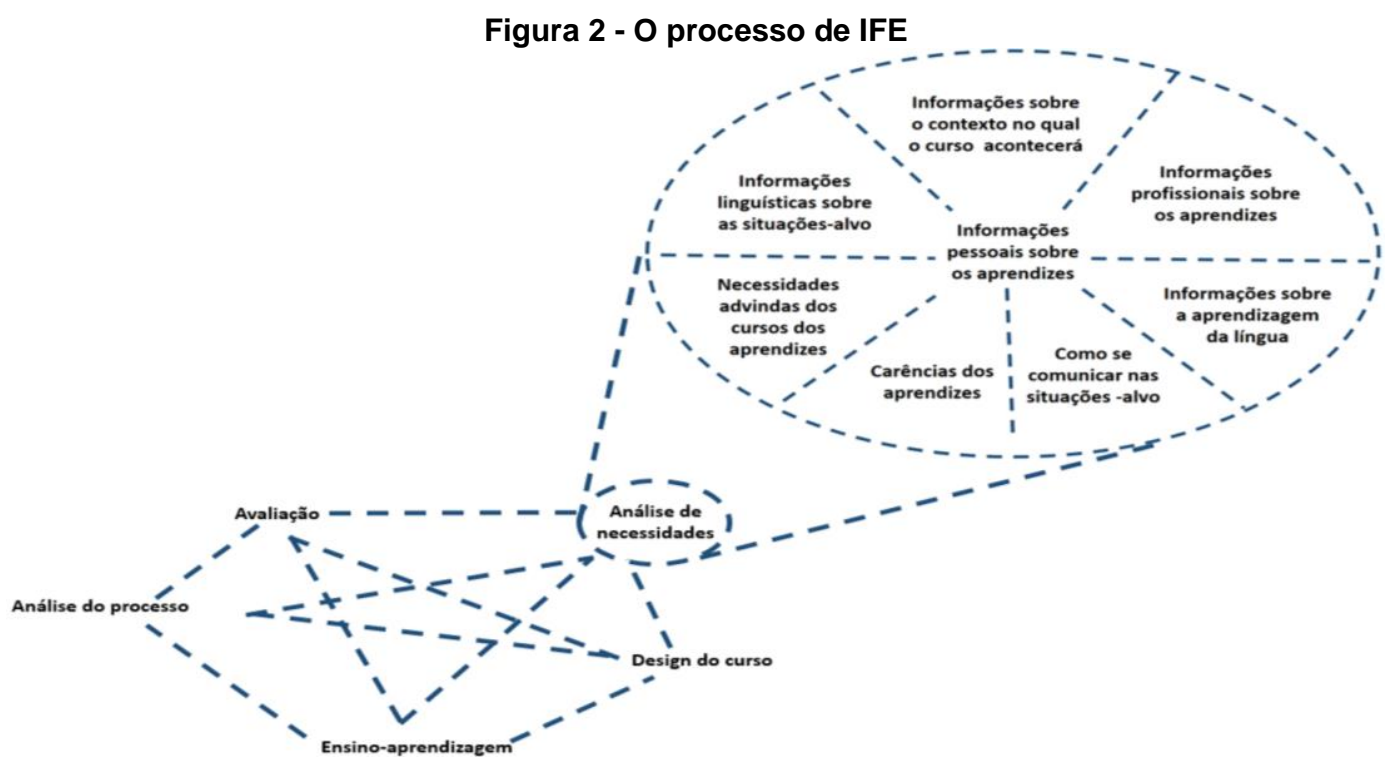

Fonte: Elaborada a partir da junção de duas figuras de Dudley-Evans e St. John (1998) 


\subsubsection{2 \\ O IFE no Brasil}

O IFE no Brasil tem se desenvolvido, desde seu começo, no "desbravar de caminhos", "sobrevivendo a obstáculos, preconceitos e mitos, fortificando-se nos desencontros" (FREIRE, 2009, p. 11) e gerando reflexões e discussões que tiveram grande repercussão no desenvolvimento de pesquisas das áreas de ensino-aprendizagem e de formação de professores de línguas no país (KLEIMAN, 1994; LIMA-LOPES.; FISCHER; GAZOTTI-VALLIM, 2015). Nas próximas linhas, descrevo brevemente alguns momentos dessa história, sobretudo com base em textos de alguns de seus protagonistas, como os autores dos artigos no livro 'A abordagem instrumental no Brasil' (CELANI et al, 2009), por exemplo.

A 'aventura ousada' (CELANI, 2009a, p. 17) do IFE no Brasil teve início como uma "reação à uma necessidade" (RAMOS, 2008, p. 70) - a de preparar professores de inglês de diversas universidades brasileiras por todo o território nacional para atender à grande demanda de aulas de IFE, nomeado na época como 'Inglês Instrumental', para as áreas científicas de suas universidades. Sabendo dessa carência e com vistas a responder aos inúmeros pedidos de esclarecimentos sobre IFE como os dos professores que vinham de diferentes estados brasileiros cursar disciplinas no programa de Linguística Aplicada da Pontifícia Universidade Católica de São Paulo (PUC-SP), a Professora Doutora Maria Antonieta Alba Celani se engajou na busca de recursos para criar um projeto amplo, que abarcasse instituições do norte ao sul do país. Como nos conta a própria Celani, em 1977, com o auxílio de Maurice Broughton, professor visitante do Consulado Britânico com experiência em IFE, e com o apoio da CAPES (Coordenação de Aperfeiçoamento de Pessoal de Nível Superior), foi feita a análise de necessidades em vinte universidades de diferentes partes do Brasil (CELANI, 2009a), que confirmou a carência de um projeto para todo o país. A partir desses resultados, somados ao grande interesse e acolhimento da iniciativa por participantes de quatro seminários realizados em 1979, foi elaborado um pedido formal de auxílio ao governo britânico, que foi concedido por quatro anos (e depois estendido) e incluía a participação de três especialistas residentes: John Holmes, Mike Scott e Tony Deyes.

Assim, nascia o Projeto Nacional Ensino de Inglês Instrumental, coordenado por Celani, com o apoio do Conselho Britânico e de auxílios parciais da CAPES e do CNPq (Conselho Nacional de Desenvolvimento Científico e Tecnológico) e com 
a PUC-SP como instituição responsável por sua implantação e seu desenvolvimento, bem como pela sua difusão (CELANI, 2009a; RAMOS, 2008). Seu grande marco inicial foi o primeiro Seminário Nacional de Inglês Instrumental em 1980, quando foram tomadas algumas decisões que caracterizaram o projeto brasileiro (HOLMES; CELANI, 2006; CELANI, 2009a, p. 19): não adotar livro didático, implementar a autoavaliação constante, garantir a diversidade e as culturas locais e dar plena autonomia às instituições parceiras na seleção de participantes. Também foi estabelecido que o programa de desenvolvimento de professores seria implementado, principalmente em forma de seminários regionais e locais, motivando a troca de experiências e o engajamento efetivo de todos os envolvidos (RAMOS, 2008).

Com o tempo, o projeto se expandiu e ganhou maior força após a adesão das então Escolas Técnicas Federais (CELANI, 2009a, RAMOS, 2008), como é o caso do instituto em que a presente pesquisa foi feita. Nos anos que se seguiram, foram desenvolvidas algumas formas de ajudar as diferentes instituições participantes, como a criação de um centro de recursos para a comunicação e troca de materiais, o CEPRIL (inicialmente a sigla para Centro de Pesquisas, Recursos e Informação em Leitura, que mudou com a expansão de sua atuação e das necessidades e é conhecido hoje como Centro de Pesquisas, Recursos e Informação em Linguagem); a realização de seminários e oficinas; e as numerosas publicações sobre o projeto, como os Working Papers, a revista The ESPecialist e outros artigos em periódicos diversos, bem como em livros (CELANI et al, 2009).

É importante frisar que o projeto era uma "gigantesca operação" (CELANI, 2009a, p. 19) sem precedentes e cheia de incertezas: tudo era muito novo, uma iniciativa envolvendo diferentes instituições do país que dependia da colaboração e envolvimento de muitos e que se pautava na análise das necessidades e em sua interpretação pelas pessoas envolvidas. Além da construção do projeto em si, outros desafios surgiram no caminho, como os de tecer relações mais estreitas entre as instituições participantes para conseguir trabalhar juntos e de lidar com a negatividade associada ao Inglês Instrumental (visto como uma atividade pouco nobre) e fazer com o que os profissionais melhorassem sua autoestima (RAMOS, 2008; CELANI, 2005; 2009a; FREIRE, 2009; FIGUEIREDO, 2009).

Foi preciso também romper paradigmas e "sair do estabelecido historicamente para o desconhecido" (CELANI, 2009a, p. 21). Assim, o projeto não estava preso a posicionamentos teóricos aceitos na época e, por vezes, inovava na busca de atender às necessidades que se apresentavam. Alguns exemplos 
desse fato são o uso de textos autênticos com os alunos (não se limitando a escolher o que ler a partir de certos padrões sintáticos e vocabulário previamente ensinados) e o emprego do português como língua de sala de aula pelos praticantes de IFE, o que 'traía' um dos princípios da abordagem comunicativa (CELANI, 2009a, p. 21).

Além disso, o IFE no Brasil quebrou algumas tradições sobre ensinoaprendizagem, como, por exemplo, a de transmissão de conhecimento pelo professor e a definição de conteúdo a partir de livros didáticos, dando espaço a uma forma mais autônoma de proceder. Desse modo, decisões "sobre conteúdos, materiais didáticos e metodologias" foram baseadas "nas razões para aprender" (CELANI, 2009a, p. 23) e o próprio conhecimento passou a ser visto como algo a ser compartilhado entre todos, entre professores e entre professores e alunos. Como resultado, foi necessário aprender a conviver com a mudança, pesquisar, produzir e se renovar constantemente. Um grande exemplo dessa atitude é o livro ESP in Brazil: 25 years of evolution and reflection de Celani, Deyes, Scott e Holmes, em que os autores lançam seu olhar sobre suas próprias publicações no período de 1980-1989 com o objetivo de analisá-las e discutir suas contribuições e sua relevância para seu momento presente (CELANI et al, 2005). Posso citar também as próprias mudanças nas nomenclaturas de eventos, cursos, disciplinas e materiais, como o curso de julho ministrado pela PUC-SP, originalmente denominado 'Metodologia de Ensino de Inglês Instrumental' que passou a ser intitulado 'Buscando Novos Caminhos: Inglês Instrumental' (RAMOS, 2009a). Tais mudanças não ocorreram por acaso e refletem como a 'grande família de IFE' estava e está crescendo não só em números de membros, mas também em suas perspectivas, haja vista os muitos textos escritos por integrantes professores de diferentes línguas sobre suas experiências em várias partes do país. Destes, gostaria de chamar a atenção para algumas pesquisas desenvolvidas em teses e dissertações (como as de MONTEIRO, 2009; SOUZA, 2016; D'ANDREA, 2016; e CAVALCANTI, 2016, dentre outras), bem como para os artigos reunidos nos livros 'A abordagem instrumental no Brasil' (CELANI et al, 2009) e 'Perspectivas em Línguas para Fins Específicos' (LIMA-LOPES; FISCHER; GAZOTTI-VALLIM, 2015), que muito me ajudaram no presente trabalho e que ilustram bem como a abordagem foi acolhida em diferentes partes de nosso território.

Na década de 1990, houve o término oficial do Projeto Nacional Ensino de Inglês Instrumental. Contudo, apesar de a ajuda financeira ter cessado, o ensino de IFE já era uma área bem estabelecida no país (RAMOS, 2008) e tinha muitos multiplicadores. Seus participantes, que agora formam uma comunidade cada vez 
maior e produtiva, englobando também outras línguas e não mais somente o inglês, continuaram se reunindo periodicamente. Hoje em dia, nossos principais encontros acontecem no Congresso Nacional de Línguas para Fins Específicos (tendo as três primeiras edições sido realizadas em 2010, 2012 e 2015).

Segundo Ramos (2009a), também foi em meados da década de 1990 que o ensino de IFE começou a se dedicar a atender "a necessidade de produzir novos fazeres" (RAMOS, 2009a, p. 41) e mudar alguns elementos metodológicos e pedagógicos adotados na abordagem até então: retomou-se a discussão sobre o ensino-aprendizagem das quatro habilidades comunicativas (produção e compreensão oral e escrita) e, sob a influência de teorias funcionalistas e de gênero e à luz da visão sociointeracionista de Vygotsky, começou-se a repensar os papeis dos alunos e professores e sua interação e reforçar ainda mais a importância do contexto, bem como iniciou-se a discussão sobre o desenvolvimento das aulas a partir de gêneros discursivos. Esses assuntos foram pauta de vários de nossos eventos nacionais e muitas pesquisas foram feitas, que geraram artigos, dos quais enfatizo a proposta de Ramos (2004) para implementação de gêneros em aulas de IFE, recorrentemente usado até hoje em nossa área. Outra temática que tem recebido muita atenção é o ensino usando diferentes ferramentas em ambientações diversas (online, por exemplo), que está diretamente ligado à necessidade cada vez mais premente de formação tecnológica dos professores (RAMOS; FREIRE, 2009; RAMOS, 2009b), mas ainda são escassos trabalhos que contemplam os multiletramentos destes e de seus alunos (SOUZA, 2016).

Em meio às muitas conquistas e aprendizados conjuntos, a abordagem de IFE também sofreu algumas críticas ao longo de seu desenvolvimento, que abarcam, por exemplo, certas decisões tomadas a partir da análise do que era preciso nos momentos preliminares da instauração do IFE no Brasil (como o foco no ensino de leitura em detrimento das outras três habilidades, a não modificação dos textos de acordo com o nível de proficiência dos alunos e o uso de português na sala de aula). Observações negativas a essas e outras medidas circunstanciais acabaram por rotular o IFE, restringindo, de forma equivocada, seu entendimento por toda a comunidade de ensino de línguas do país, alheia a um dos pontos basilares da abordagem: a volta recorrente às necessidades. Nas palavras de Celani (2009a, p. 23), eles eram 'pós-método'10 e não sabiam. Não é à toa que

10 Kumaravadivelu (2001) propõe uma Pedagogia Pós-método que se apoia em três pilares entrelaçados, a saber: a) uma pedagogia da particularidade, por considerar que a prática pedagógica deve dar importância ao contexto específico, suas peculiaridades, a situação local em todos os seus aspectos (linguísticos, socioculturais, ideológicos e políticos); uma pedagogia da praticalidade, em 
Maximina Freire diz que a história do IFE no Brasil foi e continua sendo de "rupturas e desbravamentos" (FREIRE, 2009, p.11). Ainda assim, muitos foram os mitos criados e alguns deles são discutidos na seção a seguir.

\subsubsection{3 \\ Os mitos que rondam o ensino de IFE no Brasil}

Durante o desenvolvimento do IFE no Brasil, surgiram algumas ideias equivocadas que "preocupam e que levam a indagações e questionamentos" (CELANI, 2009a, p. 25). Aqui, listo os mitos descritos por Ramos (2005, p. 116 e 117) acrescidos de outros derivados de comentários recorrentes nos textos da área e em conversas entre professores de língua inglesa no Brasil ${ }^{11}$ :

1. Inglês para Fins Específicos é inglês técnico para leitura;

2. O que se ensina são estratégias e vocabulário específico;

3. Não se usa dicionário;

4. Não se ensina gramática;

5. As aulas têm que ser sempre ministradas em português;

6. Quem não sabe inglês direito, vai dar aula de IFE;

7. Só é possível ensinar IFE depois que o aluno domina o "inglês básico";

8. A aprendizagem é manca, falha, não considera a formação integral do indivíduo;

9. A aula é sempre monótona, pragmática e utilitária;

10. IFE é um assunto esgotado, fora de moda como área de ensino e de pesquisa.

A maior parte deles foi gerada por "desencontros de interpretação" (CELANI, 2009a, p. 25), como aconteceu quanto à recomendação de se concentrar na habilidade de leitura, que acabou distorcida: não havia proibição a outras

que teoria e prática trabalham juntas permitindo ao professor "teorizar com base na prática e praticar aquilo que ele teoriza" (KUMARAVADIVELU 2001, p.541); e uma pedagogia da possibilidade, empoderando os professores e alunos, conscientizando-os sobre suas necessidades sociais e identitárias aptas a transformações. Como bem observado por Celani (2009a), esses princípios são bem similares aos que nortearam o desenvolvimento da abordagem de IFE no Brasil.

11 Neste estudo, incorporo mitos que envolvem os participantes no ensino de IFE, seu desenvolvimento futuro e a aula em si. O mito 6 , por exemplo, que se refere às competências e habilidades do professor que trabalha com a abordagem, é citado por Ramos (2005, p.111) entre outros autores. Apesar de a autora não listá-lo como mito, eu decidi incluí-lo, pois tal asserção, assim como as nos mitos 9 e 10, foi citada seguidamente por diferentes grupos de estagiários e por colegas professores de inglês pesquisadores de outras áreas. 
modalidades e essa orientação foi dada a partir da análise de necessidades em um certo momento histórico e em circunstâncias específicas. Da mesma forma, as aulas podem ser conduzidas em português, se for constatado que essa é a melhor maneira de alcançar os objetivos e não por incapacidade do professor. Outro ponto de controvérsia é sobre a gramática porque, ao contrário do que acontecia em famosos métodos de ensino quando o IFE teve início no Brasil, nessa abordagem, ela não figura como o foco da aula e deve ser contextualizada. Assim, ao se entender, por exemplo, que os alunos precisam ler artigos científicos na situação-alvo, a gramática não será totalmente ignorada, mas possivelmente estará integrada à aula de outras formas, como ao ensino de estratégias para interagir com esses textos.

No que concerne ao mito sobre a restrição ao inglês técnico, percebe-se a falta de conhecimento quanto à análise de necessidades, posto que ela deve avançar a etapa de investigação e ensino do registro, que constitui, historicamente, a primeira fase de desenvolvimento em IFE. Hoje, assim como as estratégias, esse é apenas um dos aspectos a se considerar. Outro desencontro se refere à proficiência que o aluno deve ter para iniciar seus estudos em IFE. $O$ que seria esse "inglês básico" que o aluno deve ter, já que "o que é básico para um garçom não o será para um piloto" (RAMOS, 2005, p. 117)? O primeiro passo de qualquer curso é analisar as necessidades e indubitavelmente, diferentes grupos de alunos apresentarão níveis distintos de experiência com a língua e com a disciplina e/ou atividade específica, sendo esta última tão, ou até mais, importante do que o nível na língua estrangeira. Portanto, o ponto de partida deve ser o aluno "como pessoa, usuário da língua e aprendiz" (DUDLEY EVANS; ST. JOHN, 1998, p. 126), uma das premissas fundamentais da abordagem.

Já os mitos 8 e 9 estão diretamente relacionados aos dois primeiros: Se o IFE fosse realmente o ensino de inglês técnico exclusivamente para leitura, cujo único objetivo fosse ensinar estratégias e vocabulário técnico, certamente a aprendizagem poderia ser avaliada como manca e a aula monótona, pragmática e utilitária. Como em qualquer outra situação, ela pode ser, mas não tem que ser necessariamente, pois não é o IFE que dita certos parâmetros a seguir, mas os participantes que fazem o curso acontecer. Para esclarecer esse ponto, volto à indispensabilidade de recorrer à análise de necessidades constantemente. Além disso, é preciso destacar nessa discussão um ponto por vezes negligenciado, mas que deve figurar nos cursos de IFE: a promoção do pensamento crítico (SCOTT, 2005; JOHNS, 2015; SOUZA, 2016), que pode contribuir para a formação integral do indivíduo. 
Quanto ao ensino e pesquisa de IFE e seu futuro, as várias investigações e publicações na área mostram que não é um assunto esgotado. No Brasil, observamos uma retomada das pesquisas, com a volta da publicação do periódico The ESPecialist e o engajamento de vários grupos nessa empreitada, produzindo teses e dissertações (como SOUZA, 2013; LIMA, 2016; CAVALCANTI, 2016; SOUZA, 2016; HYPPOLITO, 2017; para citar algumas) e trocando experiências em eventos como o Congresso Nacional de Línguas para Fins Específicos e o Congresso Brasileiro de Línguas Estrangeiras na Formação Técnica e Tecnológica. Da mesma forma, em publicações internacionais, constatamos que a pesquisa em IFE está a pleno vapor. No livro The Handbook of English for Specific Purposes de 2015, por exemplo, autores renomados apresentam o levantamento das pesquisas envolvendo um tópico particular do IFE em cada um de seus capítulos e indicam possíveis encaminhamentos futuros. Para Johns (2015, p. 22), o que o futuro reserva para o IFE pode ser resumido em quatro palavras: variedade, contexto, complexidade e crítica (por meio da autorreflexão). $\mathrm{Na}$ verdade, como afirma John Swales (2014), ao refletir sobre o longo caminho percorrido desde o início da abordagem, o campo não só se aprofundou, mas também se tornou mais amplo. Segundo o autor, esses avanços podem ser atribuídos à revisitação de tópicos como análise de necessidades, pesquisa e ensino em IFE por meio de gêneros discursivos e o uso de novas tecnologias sob novas perspectivas, por exemplo, como também pela exploração de novos temas. Além disso, as pesquisas em algumas áreas precisam ser urgentemente ampliadas, como é o caso da formação de professores de IFE (BASTURKMEN, 2014), sendo essa uma das razões para o desenvolvimento do presente estudo.

Ramos (2005, p.122) discute como desconstruir esses mitos e nos desafia a questionar: "sucumbir ou combater o mito?" Sem dúvida, minha réplica imediata é "combatê-lo por meio do diálogo", o que pode começar pela discussão sobre a abordagem na formação inicial de professores. No caso da equipe de IFE do instituto, debatemos esses pontos com os estagiários que nos acompanham e eles têm a oportunidade de vivenciar o ensino de IFE.

\subsection{2}

\section{A preparação do profissional de IFE}

Para Ramos (2012), a área de IFE precisa de maior atenção dos pesquisadores, posto que, apesar de a demanda por profissionais qualificados 
para o ensino de IFE ser urgente, a formação dos mesmos é escassa na modalidade presencial, sendo ainda mais exígua à distância.

Professores vinham de diferentes partes do país para fazer um curso preparatório nas férias de julho na PUC-SP, que, inicialmente estava sob responsabilidade dos especialistas britânicos quando o Projeto Nacional de Inglês Instrumental estava em vigor e, depois de seu término, passou a ser ministrado pelas professoras Rosinda Ramos e Maximina Freire (RAMOS, 2009a). Infelizmente, o curso já não existe mais desde 2001. Outras iniciativas surgiram para atender docentes que buscam uma formação em IFE, como, por exemplo, o ESPtec (que se refere ao Projeto Formação de Professores e Multiplicadores de Ensino-Aprendizagem de Inglês Instrumental para o Ensino de Educação Profissional de Nível Técnico) desenvolvido entre 2004 e 2006 sob a coordenação de Rosinda Ramos (RAMOS; FREIRE, 2009). Entretanto, podemos observar que nos cursos de licenciatura em Letras no Brasil, raramente são oferecidas disciplinas obrigatórias de IFE na graduação, sendo a Universidade Federal de Uberlândia (com a disciplina Metodologia de Ensino de Inglês para Fins Específicos no sexto período) uma das exceções.

Muitos de nós, professores de IFE, aprendemos no dia-a-dia, já que, como afirma Vian Jr. (2015), fora do contexto do Projeto Nacional Ensino de Inglês Instrumental, que investiu muitos esforços na formação de professores com cursos e seminários entre outras iniciativas enquanto ele vigorava, poucas são as iniciativas quanto à formação de professores de IFE. No entanto, como observado pelos estagiários participantes desta pesquisa, existem diferenças entre ministrar aulas de IFE e de Inglês Geral, o que normalmente gera muita apreensão no início do estágio. Esse sentimento também surgiu e foi registrado durante a implementação do Projeto Nacional Ensino de Inglês Instrumental quando foram dados os primeiros passos da abordagem no país, como nos relata Figueiredo (2009, p. 89): o primeiro seminário resultou em alívio porque os professores compartilhavam uma grande angústia, principalmente pela responsabilidade quanto ao material didático. Isso se deve ao fato de que, na prática, "o professor de IFE é um professor de inglês para fins gerais que se viu na iminência de ministrar aulas para fins específicos" (VIAN JR., 2015, p.188). Mas, quais são exatamente as atribuições desse professor?

Primeiramente, é preciso esclarecer que o professor de IFE tem uma multiplicidade de papeis a desempenhar, tanto que Swales (1985) sugere chamálo de praticante de IFE (ESP practitioner) ao invés de simplesmente professor. De fato, ensinar é apenas um dos aspectos envolvidos no trabalho. Segundo Dudley- 
Evans e St. John (1998, p. 13), esses profissionais devem exercer papeis como produtores de materiais, planejadores de cursos, colaboradores, avaliadores e pesquisadores.

Assim, cabe ao profissional de IFE selecionar textos e outros materiais e adaptar e/ou produzir atividades apropriadas para as suas turmas. Além disso, ele deve ajudar seus alunos a ter acesso à comunidade discursiva específica na qual eles precisarão desempenhar suas funções, grupo do qual o próprio professor normalmente não é membro (PARKINSON, 2013). Para tanto, ele precisará do auxílio dos próprios alunos e de outros professores e profissionais da área específica.

Desse modo, apesar de ser o organizador das tarefas e constante pesquisador do campo de atuação de seus aprendizes, o professor não deve ser visto como o provedor de conhecimento, mas, ao contrário, um mediador que constrói o conhecimento junto com os alunos, ajudando-os na negociação de significados. Na verdade, o profissional de IFE não leciona as disciplinas específicas dos aprendizes (como química, eletromagnetismo, anatomia, entre outras) em inglês, sendo esse mais um equívoco, uma crença, que gera temor nos iniciantes e estagiários. Nesse contexto, admite-se que muitas vezes o professor não é o par mais competente ${ }^{12}$, deixando ainda mais claro que nas aulas todos ensinam e aprendem.

Além disso, o professor é o avaliador de todas as etapas: da análise de necessidades, dos materiais e atividades escolhidas, das aulas, da resposta dos alunos e do que precisa ser mudado, desenvolvido e/ou reestruturado. Esse processo não precisa ser solitário porque os alunos e outros professores de IFE e das áreas específicas podem contribuir muito.

Com o tempo e as diferentes situações, as atividades desempenhadas pelo profissional de IFE só se avolumam. Dentro de uma função, como a de pesquisador, outras podem se abrir como, por exemplo, a de palestrante (FIGUEIREDO, 2009). Em um nível pessoal, a função que tem me exigido maior dedicação nos últimos anos é a de orientadora de licenciandos, que são acolhidos para participar das práticas da equipe de inglês do instituto durante o seu estágio nas aulas de IFE.

\footnotetext{
12 Vygotsky (1998) ressalta a interação como principal recurso para o desenvolvimento das capacidades cognitivas. Assim, com o auxílio de alguém com mais experiência, ou seja, o par mais competente, a pessoa pode avançar mais. Normalmente consideramos que o professor tem mais conhecimento para compartilhar do que os alunos, mas no caso da aula de IFE, muitas vezes o aluno é o par mais competente.
} 


\title{
3 Identidade: um processo em constante (re)construção
}

\begin{abstract}
Thinking, knowing, believing, and doing are enacted in classroom contexts in a way that cannot be separated from identity formation. What teachers know and do is part of their identity work, which is continuously performed and transformed through interactions ${ }^{13}$.
\end{abstract}

(MILLER, 2009, p. 175)

No presente capítulo, prossigo no delineamento da fundamentação teórica ancorada em uma visão socioconstrucionista de identidades (MOITA LOPES, 2003; BUCHOLTZ; HALL, 2003 e 2005), bem como apresento o arcabouço utilizado para analisar os dados gerados. Assim, após descrever o enfoque sobre identidades adotado nesta pesquisa, principalmente com base em Giddens (2002), Bauman, (2005), Hall (2005), Bucholtz e Hall (2005), Moita Lopes (2003) e De Fina (2011), discuto os princípios propostos por Bucholtz e Hall (2003; 2005) para entender as identidades como um fenômeno sociocultural construído discursivamente. Em seguida, discorro sobre o conceito de identidades coletivas, concentrando-me nas comunidades de prática. Além disso, trago à baila as contribuições de Marcelo (2009) sobre identidades docentes, que também fazem parte das (re)construções identitárias de Elis. Por fim, discuto a relação entre identidades, crenças e emoções partindo do pressuposto de que tanto quem estamos nos tornando, como em que acreditamos, o que pensamos, sabemos, fazemos (FABRICIO; MOITA LOPES, 2002; OLIVEIRA; BARCELOS, 2012) e, acrescentaria à epígrafe, sentimos (ZEMBYLAS, 2005), estão em constante processo de negociação, adaptação e reformulação nas interações e contextos situacionais, socioculturais e históricos pelos quais transitamos.

\section{1}

\section{A concepção de identidades}

Nas últimas décadas, estudos sobre identidades têm crescido exponencialmente, contando com contribuições de diferentes áreas do conhecimento. Segundo Moita Lopes (2003), tal interesse advém das grandes alterações que enfrentamos em várias frentes (culturais, sociais, econômicas,

\footnotetext{
13 Pensar, saber, acreditar e fazer são realizados nos contextos de sala de aula de forma que não podem ser separados da formação de identidades. O que os professores sabem e fazem é parte de seu trabalho identitário, que é continuamente executado e transformado por meio das interações.
} 
políticas e tecnológicas), que fazem fervilhar questionamentos sobre nossos papeis na vida. Essa visão é corroborada por De Fina (2011, p. 264), que afirma que, nos últimos anos, houve uma mudança de perspectiva que pode ser atribuída não só aos desenvolvimentos dentro dos estudos do discurso, mas também pelas crescentes influências de linhas de pensamento e movimentos que vêm de diversas disciplinas.

Para explicar melhor essa mudança de concepção, Hall (2005) distingue três formas de definir as identidades, a saber: a do sujeito iluminista, que considera que, apesar de se desenvolver, o indivíduo continua essencialmente o mesmo ao longo de sua vida pois possui um "centro", um núcleo interior, não suscetível a mudanças; a do sujeito sociológico, cuja identidade é moldada a partir da interação com o outro; e a do sujeito pós-moderno, que avalia as identidades como fragmentadas, fraturadas e múltiplas. Nessa última concepção, que é a tomada neste trabalho, o sujeito é construído por diversas identidades (GIDDENS, 2002; BAUMAN, 2005; HALL, 2005), por vezes contraditórias, "empurrando em diferentes direções de tal modo que nossas diferentes identificações estão sendo continuamente deslocadas" (HALL, 2005, p. 13).

As identidades estão em constante reformulação, o que é ampliado pelos fenômenos de radicalização da reflexividade (GIDDENS, 2002) pela atual possibilidade de revisão desenfreada de conhecimentos, o que torna a modernidade tardia ainda mais imprevisível; e de liquidez (BAUMAN, 2005), que faz a construção das identidades ser sempre um projeto impossível de se completar. É a partir dessa perspectiva que olho para o estágio, considerando que, na atual conjuntura, nossas identidades "flutuam no ar" e estão em "negociação permanente" (BAUMAN, 2005, p. 19) com nossos pares nas situações das quais tomamos parte.

Em um mundo pós-moderno caracterizado pela incerteza, bem como pela experiência de fluidez e desunião (DE FINA, 2011), construímos a nós mesmos e aos outros e mostramos a nossa visão da realidade a partir de quem estamos sendo em um determinado momento. Em outras palavras, as identidades não são prontas e fixas, mas múltiplas, fragmentadas e fluidas (MOITA LOPES, 2003), nos permitindo adaptação nas diferentes práticas discursivas. No entanto, ao mesmo tempo, elas são influenciadas pela complexidade do contexto do qual fazemos parte. Portanto, as identidades são constituídas nas interações, que não ocorrem em um vácuo, mas estão sempre interligadas aos (e são influenciadas pelos) contextos específicos em que ocorrem, nos níveis micro e macro (BUCHOLTZ; HALL, 2005). Assim, como Moita Lopes (2003), De Fina (2011) e Bucholtz e Hall 
(2005), assumo uma definição de identidades com base no socioconstrucionismo, que as descreve como plurais e complexas, pois negociadas nas nossas interações e ações no mundo, sendo dependentes das diferentes variáveis situacionais, sócio-históricas e culturais que fazem parte do nosso dia-a-dia.

Para tornar possível a tarefa de análise das identidades emergentes nos discursos de Elis, foi necessário buscar e selecionar parâmetros que me ajudassem a organizar esse tema de natureza tão complexa. Na próxima seção, trago contribuições de Bucholtz e Hall (2003; 2005), que propõem uma forma de analisar como as identidades são construídas a partir de cinco princípios, que discuto a seguir.

\section{2 Identidades sob uma perspectiva sociocultural}

Considerando que as identidades são construídas na interação, podemos perceber diferentes tipos de identidades dependendo dos agentes envolvidos e dos processos de comunicação (DE FINA, 2011, p. 268). De Fina (2011) faz a distinção, por exemplo, entre identidades pessoais (construtos que podem incluir características físicas e morais e até mesmo a identificação com grupos), identidades sociais (como o pertencimento a grandes grupos envolvendo categorias abrangentes como religião, política, gênero, etc.) e situacionais (dependentes do contexto específico), mas essas diferenciações acontecem nos discursos de forma contingente, posto que, nas interações, não existem traços tão definidos e essas características são entrelaçadas. Para tratar do tema, Bucholtz e Hall $(2003 ; 2005)$ articulam pesquisas de variados campos e teóricos a partir de uma perspectiva interdisciplinar ${ }^{14}$ que integra linguagem, cultura e sociedade, e oferecem uma abordagem para a análise das construções identitárias, estabelecendo cinco princípios fundamentais para seu estudo: emergência, parcialidade, posicionalidade, indexicalidade e relacionalidade. Antes de explicitar cada um deles, as autoras explicam que alguns desses princípios rompem com visões psicológicas e estáticas amplamente difundidas no meio acadêmico, como também ampliam as formas de olhar as identidades para abarcar não somente o macro, mas também "categorias etnográficas locais e posições interacionais

\footnotetext{
${ }^{14}$ As autoras partem da premissa de que a identidade é um construto que "opera em múltiplos níveis simultaneamente" (BUCHOLTZ; HALL, 2005, p. 586), apesar de admitirem dar maior destaque ao nível interacional para descrever os princípios orientadores para os estudos sobre identidade.
} 
transitórias", partindo de uma noção de identidade "intersubjetiva" e "interacionalmente emergente" (BUCHOLTZ; HALL, 2005, p. 587), pontos cruciais para esta tese. A figura 3, elaborada por mim, busca resumir os princípios fundamentais propostos por Bucholtz e Hall (2005) para o estudo das identidades.

Figura 3 - Princípios fundamentais para o estudo de identidades

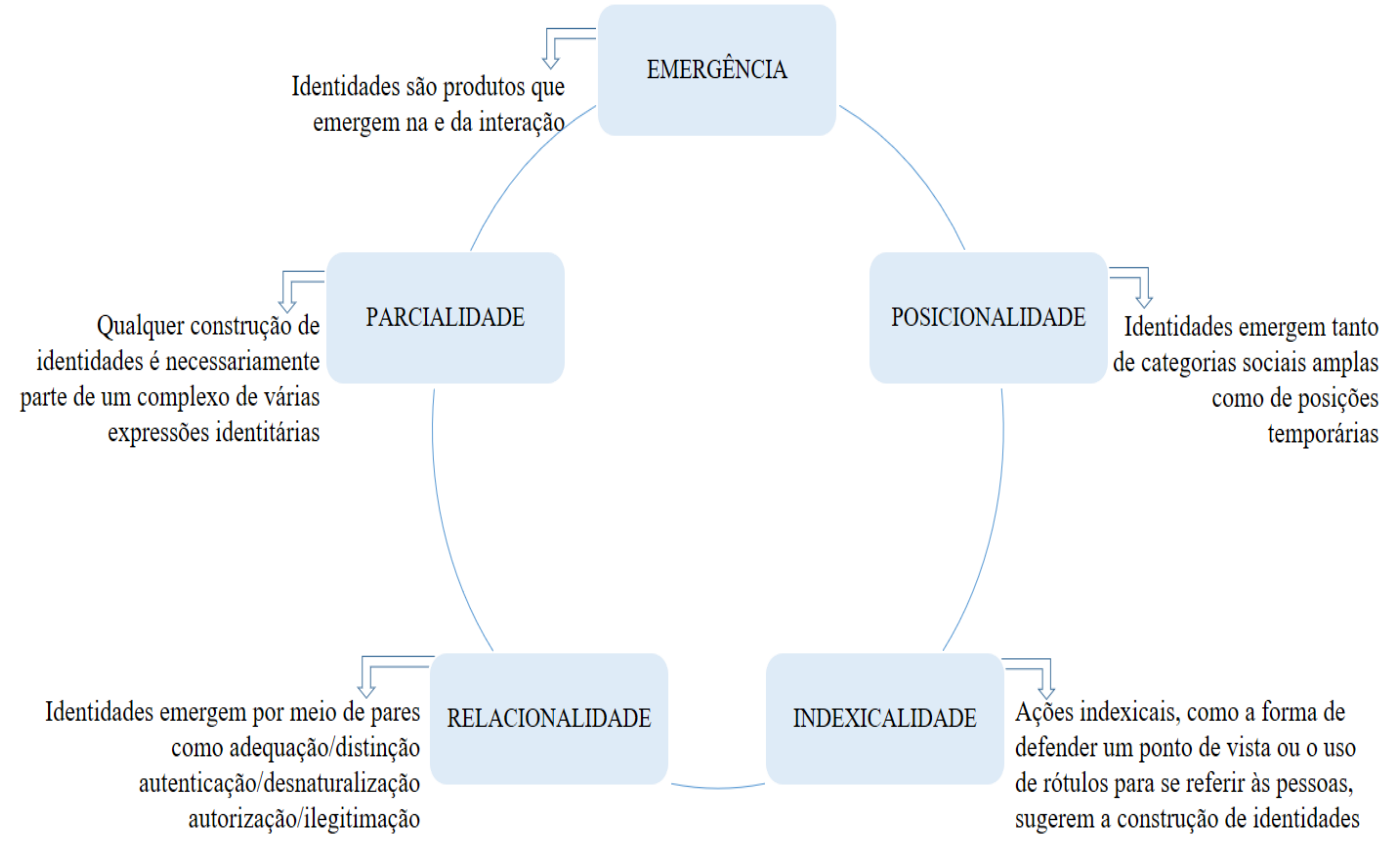

Fonte: Figura de minha autoria

O primeiro princípio, o de emergência, postula que a identidade é fundamentalmente um fenômeno cultural e social, o que contesta o conceito tradicional que a define como característica essencialmente psicológica e interna, fonte pré-existente das práticas linguísticas e outras semioses, tidas apenas como reflexo do estado mental do indivíduo. Ao contrário, segundo esse princípio, a identidade é um produto que emerge pela interação.

Já de acordo com o princípio de parcialidade, a construção identitária está em constante mutação tanto no processo de desdobramento da interação quanto através dos contextos discursivos, de modo que é impossível classificá-la como sendo de uma forma apenas. Assim, ela pode ser em parte deliberada e intencional e em parte habitual (por isso, por vezes, não totalmente consciente), em parte produto da negociação e contestação interacional, como também parcialmente resultado das percepções e representações de outros, e em parte um efeito dos processos ideológicos e estruturas materiais que podem apresentar relevância para a interação.

É importante frisar que esses dois primeiros princípios apresentados, o de emergência e o de parcialidade, são essenciais para discutir a (re)construção das 
identidades de Elis, mas são conceitos amplos aplicáveis em todas as instâncias tratadas e estarão presentes mesmo que por vezes eu não os mencione na análise. Portanto, considero que, a todo o momento, nos dados analisados, identidades emergem como resultado das interações (princípio de emergência). Da mesma forma, as identidades são fluidas e múltiplas e emergem na interação em contextos específicos como um complexo emaranhado de característica parciais (princípio de parcialidade) ao invés de um todo unificado.

Procurando não se ater à também costumeira categorização de identidades a partir de características sociais amplas (tais como idade, gênero e classe social), o princípio de posicionalidade mostra como nossas identidades podem ser temporárias e locais. Portanto, as identidades abrangem, ao mesmo tempo, categorias demográficas de nível macro; posições culturais etnográficas e locais; e papeis de participantes e posicionamentos específicos.

O princípio de indexicalidade estabelece que as relações identitárias emergem na interação através dos processos de indexação, formas linguísticas que dependem do contexto interacional para seu significado, reiterando que elas são produzidas discursivamente. Tais processos incluem:

- A utilização de categorias linguísticas classificadas como dêiticos. O uso de pronomes ou locuções pronominais, por exemplo, expressa relações indexicais diretas como em "para que eu me acostume com minhas futuras funções", quando Elis se refere a si mesma;

- Menções públicas de rótulos e categorias identitárias, como 'estagiário', 'professor regente' e 'professor de Prática de Ensino', por exemplo;

- Implicações e pressuposições em relação às posições identitárias de si e de outros;

- Orientações avaliativas e epistêmicas que emergem durante a interação discursiva, bem como os papeis de participantes e posicionamentos interacionais. Proponho aqui analisar tais orientações com o auxílio da Linguística Sistêmico-Funcional e do Sistema de Avaliatividade, que são tema do capítulo 5;

- O uso de estruturas e sistemas linguísticos que estão ideologicamente associadas a personas e a grupos específicos.

Por último, o princípio de relacionalidade estabelece que a identidade é construída intersubjetivamente por meio de diversas relações complementares que constantemente se sobrepõem, tais como: adequação/distinção, 
autenticação/desnaturalização e autorização/ilegitimação. Em um artigo de 2003, Bucholtz e Hall classificam esses três pares de conceitos, que estão interrelacionados e são centrais para as identidades, como "táticas de intersubjetividade" (BUCHOLTZ; HALL, 2003, p. 382 e 383).

O primeiro par, adequação/distinção, corresponde às formas pelas quais os indivíduos constroem similaridade e diferença. Assim, as pessoas podem destacar características comuns, que não são iguais, mas suficientemente adequadas para os propósitos interativos em um dado momento, ao passo que minimizam as dessemelhanças, desde que elas sejam irrelevantes e não prejudiciais (adequação). Da mesma forma, o contrário pode ser feito quando as pessoas reforçam os aspectos que as diferenciam, dando proeminência a essas dessemelhanças (distinção). Assim, quando Elis diz que "por enquanto todas as turmas nos trataram bem", esse 'nos' se refere ao grupo de estagiários e, nesse exemplo, ela se mostra em adequação a esse grupo, como parte dele. Para aprofundar mais a discussão de como Elis se apresenta na interação em relação aos outros participantes (alunos, professores regentes e de Prática de Ensino e estagiários), lanço mão do conceito de identidades coletivas, da noção de pertencimento e de comunidades de prática, que descrevo na seção 3.3.

Continuando a descrição das táticas de intersubjetividade propostas por Bucholtz e Hall (2003 e 2005), passo para o par autenticação/desnaturalização, que se refere aos modos que falantes constroem uma diferenciação entre o que é genuíno, real e o que parece artificial. Por um lado, pela autenticação, a identidade é apurada, ou verificada, no discurso, não com o objetivo de oferecer autenticidade, mas de prover credibilidade. Um exemplo seria usar parte do nosso texto para asseverar que somos quem dizemos ser citando as falas de outras pessoas. Em contrapartida, a desnaturalização é o processo pelo qual a identidade é artificializada discursivamente, "frequentemente operando para desestabilizar afirmações essencialistas" (BUCHOLTZ; HALL, 2003, p. 386) como uma pessoa pregando uma peça em outra se fazendo passar por um estrangeiro e revelando a brincadeira depois, por exemplo.

O terceiro par de relações, a autorização/ilegitimação refere-se aos aspectos estruturais e institucionais da formação identitária. A autorização considera a afirmação ou imposição de uma identidade através de estruturas institucionalizadas de poder e ideologia. Contudo, a ilegitimação diz respeito às maneiras pelas quais as identidades são rejeitadas, censuradas ou simplesmente ignoradas por essas mesmas estruturas. Bucholtz e Hall (2005, p. 604) ilustram a tática de autorização com um dos discursos de Bush liderando a guerra do Iraque 
em que ele usa a primeira pessoa do plural recorrentemente em diferentes partes de sua fala metonimicamente posicionando-se, como presidente, como alguém que fala em nome de todo o povo dos Estados Unidos. Já a tática de ilegitimação é exemplificada pelas autoras com um diálogo entre coreanos estudado por Park (2004 apud BUCHOLTZ; HALL, 2005, p. 604). Nesse exemplo, os coreanos zombam da pronúncia de um colega de uma palavra em inglês em uma mensagem eletrônica já que tal pronúncia é considerada por eles americanizada demais pois estão inseridos em um contexto em que é inapropriado ou 'nãocoreano' buscar falar inglês fluentemente.

A partir desses princípios, será possível perceber nos dados como as identidades de Elis são coconstruídas em um processo intersubjetivo e como elas estão em constante transformação. Acredito que esses princípios sugeridos por Bucholtz e Hall (2005) podem me auxiliar na análise proposta nesta tese juntamente com a base teórica e metodológica oferecida pela a Linguística Sistêmico-Funcional e pelo Sistema de Avaliatividade, que é tema do capítulo 4. Na próxima seção, cito brevemente os estudos de Duzak (2002) e Snow (2001) para abordar a construção de identidades coletivas e os sentimentos de pertencimento e diferenciação com relação aos outros, para então discorrer sobre comunidades de prática (LAVE; WENGER, 1991; KIELY, 2015).

\section{3 \\ A relação com o(s) outro(s) na construção de identidades}

$\mathrm{Na}$ análise dos dados desta tese, é possível perceber que Elis recorrentemente se refere aos outros para falar de si, suas experiências, sentimentos e pensamentos, sugerindo muitas vezes um senso de (não) pertencimento a certos grupos em determinadas circunstâncias e uma preocupação evidente com a visão de outras pessoas sobre ela. A temática sobre o alinhamento ou oposição com relação ao outro, já citada aqui na seção 3.2 dentro do princípio de relacionalidade de Bucholtz e Hall (2005), é também discutida por Duzak (2002), sendo que esta última destaca a perspectiva do pertencimento na construção identitária por meio do processo da comparação nós-outros.

Para Duzak (2002), o senso de pertencimento a um grupo "satisfaz o desejo humano por solidariedade, empatia, segurança ou conforto psicológico que advém do compartilhamento de algo com outras pessoas" (DUZAK, 2002, p. 2), que 
parece ser exatamente o que emerge nos dados analisados nesta tese como o que Elis busca para si. Portanto, assim como Moraes Bezerra (2011a, p. 2), chamo a atenção para o "aspecto afetivo imbricado à construção" de identidades durante o processo de (não) identificação com o(s) outro(s), especialmente por observar nos dados toda a gama de emoção envolvida na ênfase dada à forma como Elis vê seus pares, como eles a veem e à sua busca por 'se encaixar', por pertencer a essas coletividades. De acordo com Snow (2001), é nesse sentimento de pertencimento, ao qual ele se refere como "we-ness", que reside a essência das identidades coletivas.

Para melhor explicar o conceito de identidades coletivas, Snow (2001) define outros dois tipos de identidades: as sociais e as pessoais. Identidades sociais são as atribuídas aos outros para situá-los em um determinado espaço social, ligandoos a papéis socialmente estabelecidos, como "médico" e "mãe", ou em categorias mais abrangentes (envolvendo etnia, gênero ou nacionalidade, por exemplo), como 'brasileiros'. Essas categorizações funcionam como "pontos de orientação" no momento da interação (SNOW, 2001, p. 3). Já as identidades pessoais são significados que atribuímos a nós mesmos, como autodesignações e autoatribuições que nos distinguem como pessoa. Um exemplo de identidade pessoal pode ser depreendido da menção de Elis de que nunca foi "fã de química ou biologia”, em que ela se diferencia daqueles que gostam dessas disciplinas.

As identidades sociais, pessoais e coletivas se sobrepõem em muitas circunstâncias, mas as coletivas se diferenciam das outras por estarem ancoradas em experiências e atributos compartilhados entre aqueles que formam a coletividade. Ao mesmo tempo que esse senso de coletividade é reforçado, também é a sensação de contraste e diferença em relação a um ou mais conjunto(s) de 'outros', sendo eles reais ou imaginários (SNOW, 2001). Considero que, quando Elis menciona categorias como 'alunos', 'estagiários' e 'professores de IFE' ela está se referindo a diferentes identidades coletivas, pois elas apresentam um "senso compartilhado de 'nós' e um senso correspondente de 'agência coletiva"' (SNOW, 2001, p. 3).

Entretanto, esses grupos não são entendidos como fechados e excludentes. Como poderemos ver na análise dos dados, Elis algumas vezes se posiciona como parte de cada uma dessas coletividades (cada uma em um contexto distinto) e, em outras, em contraste a elas. Por exemplo, podemos perceber que algumas vezes Elis se identifica como membro do grupo de estagiários, como quando diz "onde que a gente se encaixa?", em que o 'a gente' se refere aos licenciandos recebidos no instituto para fazer o estágio. Contudo, quando fala "Se eles já usam 
o Instagram a gente podia assim pedir para eles postarem mesmo", Elis se identifica dentro do grupo de professores de IFE (aqueles que estão planejando a aula e implementarão tal planejamento na semana seguinte) com o 'a gente' em contraste com o grupo de alunos, que são 'eles'. Essa fala de Elis é também um exemplo de como identidades coletivas podem ser "ligadas a grupos que desenvolvem determinadas práticas sociais, mediadas pela linguagem" (MORAES BEZERRA, 2011a, p. 2) interessados no aprendizado mútuo, formando uma comunidade de prática, como a dos professores de IFE do instituto, na qual Elis parecia estar cada vez mais inserida. Ao conceito de comunidades de prática dedico a próxima subseção.

\subsection{1}

\section{Comunidades de prática}

O processo de aprender a ser professor, como qualquer outro aprendizado, é "uma experiência identitária" (FABRÍCIO, 2011), que pode ser desenvolvida a partir de uma perspectiva colaborativa como é o caso do estágio no instituto, considerado neste estudo como uma comunidade de prática (LAVE; WENGER, 1991). Segundo Kiely (2015), no que tange à expansão pessoal-profissional, os professores precisam explorar seu papel como agentes criativos, reflexivos e investigadores de sua própria prática. Além disso, quanto ao contexto de trabalho, é necessário um senso de comunidade que estabeleça uma cultura de colaboração conjunta entre professores. Uma estratégia para que essas capacidades sejam desenvolvidas é o foco nas identidades desses profissionais.

Kiely (2015), com base em Butler (1997 apud Kiely, 2015), parte do princípio de que a identidade não é algo fixo ou atribuído, e sim algo imaginado, dinâmico e expresso por meio de performance. A performance pode envolver alinhamento com normas estabelecidas ou resistência a elas para articular novos sentidos imaginados, posicionamento também adotado neste trabalho. Ao mesmo tempo, partindo da premissa de que estamos continuamente aprendendo e nos transformando, Kiely corrobora o conceito de identidade proposto por Wenger, já que ele se mostra muito produtivo para entender como esses profissionais podem se desenvolver. De acordo com Wenger (1998), a noção de identidade profissional provém da associação de um grupo particular e da participação em atividades, a fim de articular e desenvolver essa sociedade. 
Comunidades de prática são grupos de pessoas que compartilham experiências, interesses e preocupações relativas aos mesmos temas e atividades. Seus membros apresentam diferentes níveis de conhecimento e habilidades, mas todos podem ganhar com a troca de experiências e saberes por meio das interações (WENGER, 1998). São quatro as dimensões essenciais na teoria social da aprendizagem proposta por Wenger (1998), a saber: prática, comunidade, identidade e significado. A prática é o que faz com que conhecimentos e experiências sejam partilhadas, já que aprendemos enquanto nos engajamos em atividades, quando nos esforçamos para um objetivo comum, quando há envolvimento mútuo em ação. É na comunidade que definimos quem somos e podemos entender qual é a nossa participação nas atividades. Aprendemos construindo um sentido de pertença, trabalhando juntos e trocando informações enquanto realizamos tarefas (CUDDAPAH; CLAYTON, 2011). As identidades surgem da forma como a aprendizagem transforma quem somos e como constrói nossas histórias pessoais no contexto das nossas comunidades. $\mathrm{O}$ significado, ou o entendimento de atividades e papeis, é construído na interação e determinado pelo senso de propósito em um certo contexto, que guia nossa participação e investimento. Segundo Kiely (2015), o esforço mútuo proporciona apoio emocional e esclarecimentos conceituais aos diferentes membros, fazendoos analisar melhor suas práticas e sugerir e implementar mudanças quando necessárias.

Assim, acredito, como Murphey, Prober e Gonzales (2010), que ambientes onde as pessoas se sintam acolhidas, como parte do grupo, são positivos e saudáveis e podem construir relacionamentos significativos, fazendo-as crescer não só emocionalmente, mas também profissionalmente/academicamente. O senso de pertencimento, de inclusão e de colaboração mútua certamente ajuda na formação docente, não só a inicial, mas também a continuada. Por isso, "deveria ser ativamente contemplado e cultivado em sala de aula" (MURPHEY; PROBER; GONZALES, 2010, p. 49-50).

Avalio que o grupo de professores de inglês do instituto onde esta pesquisa foi desenvolvida forma uma comunidade de prática, um contexto muito profícuo para aprendizagem não só pela reflexão, mas também pelas oportunidades de ação, e que tem grande impacto na construção das identidades dos futuros docentes (BEDRAN, 2012). Segundo Wenger (1998), as comunidades de prática têm como núcleo os chamados membros centrais (pessoas plenamente engajadas, os líderes, experientes nos fazeres e utilização dos instrumentos e responsáveis por conduzir as atividades); outros que são membros ativos totais 
(praticantes com alto grau de envolvimento e conhecimento); e membros periféricos (que pertencem a comunidade, mas ainda são novatos). $O$ autor também cita a participação transacional (pessoas de fora da comunidade que ocasionalmente interagem com ela) dentre os quais existem aqueles que têm acesso passivo aos instrumentos ou artefatos criados pelos membros.

Um aspecto importante dessa visão é a noção de participação periférica legítima, "o processo pelo qual os novos participantes são incluídos na comunidade de prática" (WENGER, 1998, p. 100), que é o que acontece com os licenciandos que vão estagiar no instituto. Assumo, portanto, que nas negociações entre estagiários e os professores regentes de IFE e os instrumentos da comunidade de prática ocorre a aprendizagem, que pode progressivamente fazer com que o aluno-professor, um membro inicialmente periférico, se torne cada vez mais experiente.

É importante mencionar que, a partir das experiências que eu e meus colegas tivemos durante os semestres em que recebemos estagiários em nossas turmas, nossas próprias perspectivas sobre o papel dos estagiários em nossa comunidade de prática mudaram. Inicialmente, nós e os próprios licenciandos víamos o estágio muito mais como observação do que participação. Hoje, procuramos primar pelo acolhimento dos estagiários e pela criação de espaços de compartilhamento de conhecimentos, tarefas e funções com eles, que também são professores em nossas salas de aula, coconstruindo nossas identidades em nossas interações. Dentre elas, estão as identidades profissionais docentes, assunto a ser desenvolvido na seção que se segue.

\subsection{2}

\section{A construção de identidades profissionais docentes}

Como podemos concluir de tudo que está sendo discutido neste capítulo, são diversos os fatores que contribuem para a construção de identidades. $\mathrm{Na}$ área da educação, e seguindo também a perspectiva de identidades em desenvolvimento e construídas na interação ${ }^{15}$, Marcelo (2009) lista quatorze características ligadas à formação docente na busca de melhor compreender esse processo e trazer alguns temas para debate. Ele propõe características que

\footnotetext{
15 Marcelo (2009) não usa o termo 'socioconstrucionismo' apesar de mostrar o tempo todo em seu texto como fatores sociais/contextuais são essenciais na construção de identidades docentes, que é vista como um processo, "uma realidade que evolui e se desenvolve, tanto pessoal como coletivamente" (MARCELO, 2009, p.112).
} 
considera recorrentes na construção de identidades docentes e, por isso, as classifica como 'constantes'. Entretanto, como explica o autor, essa lista não é exaustiva, poderia ser organizada de outros modos e não pretende ser, de forma nenhuma, definitiva (MARCELO, 2009). Dos tópicos discutidos pelo autor, destaco alguns $^{16}$ que se mostram muito relevantes para entender como Elis interpreta o que é ser/ se tornar professora. Eles são:

\section{a. A influência das experiências como discentes e das crenças} (re)form(ul)adas ao longo da vida. Assim como Oliveira (2008) e Conceição (2013), Marcelo (2009) explica que o contexto, as experiências e as crenças estão interligados e intervém conjuntamente na forma como nos (re)construímos, mas ele nos lembra de que todos os momentos em sala-de-aula, mesmo como alunos, fazem parte do nosso percurso identitário como professores. Elis não tinha dado aulas até o início do estágio, mas isso não quer dizer que ela não tinha concepções e vivências prévias que atuam diretamente na constituição de sua(s) identidade(s) docente(s). Pelo contrário, em alguns momentos em seu discurso, ela retoma suas experiências e crenças anteriores como aluna, o que sugere que elas são parte essencial em seu processo de tornar-se professora.

b. O conteúdo lecionado. No ensino de inglês, esse tópico pode envolver questões como, por exemplo, a forma de abordar e a importância dada à gramática, ao vocabulário e aos aspectos culturais, políticos e ideológicos; a visão de leitura a partir da qual as aulas serão desenvolvidas; o posicionamento quanto às diferentes semioses; e a importância da reflexão crítica. Para o profissional de IFE, dois dos aspectos essenciais ${ }^{17}$, que inegavelmente transformam a visão do professor sobre si mesmo, sobre sua função e sobre a relação com seus alunos, como aconteceu com Elis, são: o fato de o professor ter que compartilhar a posição de par mais competente e a necessidade de pesquisa constante dos assuntos e contextos, fazendo com que os próprios conteúdos, planejamentos e sua realização em sala-de-aula estejam sempre 'em elaboração'. Cumpre salientar que é essencial que nós, professores de língua inglesa, estejamos atentos para ajudar os alunos a interagir com os diferentes textos a que têm acesso na língua estrangeira de forma a dominá-la "e não

\footnotetext{
${ }^{16}$ Apresento aqui sete tópicos, mas alguns aglutinam mais de uma 'constante' descrita por Marcelo (2009). Também tento expandir algumas delas e estabelecer relações com o contexto desta tese. Portanto, não me limito a descrever somente o que foi dito pelo autor.

17 Ver seção 2.1, onde esses aspectos foram explicados.
} 
ser dominados por ela" (RAJAGOPALAN, 2013, p. 159). Da mesma forma, devemos questionar o quê e o porquê estamos ensinando, ou seja, que interesses estão em jogo e que fundamentos ideológicos embasam nossas práticas (MOURA FILHO, 2011, p. 69). Essas premissas são muito valorizadas pela comunidade de prática da qual faço parte e que inclui os licenciandos, que trabalham colaborativamente conosco nessa perspectiva.

c. A relação entre docentes e discentes, por vezes fazendo os alunos(as) se tornarem a principal motivação profissional. Para Elis, o convívio com os alunos no estágio e o apoio emocional recíproco (MAHN; JOHN-STEINER, 2002) foram essenciais em sua caminhada identitária, como ela mesma avalia em seu memorial de estágio.

d. A carreira docente. Marcelo (2009) cita as mudanças de funções devido à progressão na carreira, mas gostaria de enfocar um outro subtema dentro do tópico proposto por ele, que é a '(des)valorização do professor'. Esse assunto era muito recorrente nas conversas com meus colegas estagiários e, consequentemente, nos dados gerados nesta pesquisa. Os licenciandos demonstram muita insegurança quanto à escolha da profissão visto que a carreira docente tem sido depreciada já há alguns anos. $\mathrm{Na}$ área de inglês especificamente, ainda há a questão da profissionalização em si, que não é valorizada: muitos são contratados como professores em algumas escolas de ensino privado e cursinhos de inglês sem ter licenciatura na área. Não são raros questionamentos e constatações negativas como, por exemplo, "Será que eu fiz a escolha certa?", "Qualquer um chega e dá aula e tem o título pela sociedade de professor de inglês" e "... é muito trabalho, é muito esforço e pouco reconhecimento. Me pergunto se vai valer à pena" ${ }^{18}$. O desânimo quanto à profissão está muito presente nos dados gerados para esta tese, ecoando a afirmação de Moura Filho (2011, p. 49) de que a "prática docente carece de encantamento".

e. A hiper-responsabilização do professor pela aprendizagem dos discentes, apontando o profissional como único culpado por qualquer adversidade. Elis menciona algumas vezes essa 'responsabilidade' do professor, que parece gerar ainda mais ansiedade nos licenciandos.

\footnotetext{
${ }^{18}$ Excertos das falas de licenciandos dos dados gerados para a presente pesquisa.
} 
f. O docente como consumidor de inovações pedagógicas, mas, ao mesmo tempo, desconfiado ante as (novas) tecnologias. Os professores muitas vezes são chamados a fazer uma 'renovação' de estratégias e usar novas abordagens que por vezes até são impostas de cima para baixo (por alguém que detenha o poder sobre esse aspecto, como empregadores, coordenadores, treinadores ou pelo governo). Essa demanda interfere em como os professores entendem seu trabalho no processo de tentar/não aceitar/falhar em se adequar. Um dos desafios dos quais o professor não pode fugir é o uso de tecnologias (que não se restringem ao uso do computador). Mesmo para Elis, uma jovem acostumada a muitos aperfeiçoamentos tecnológicos dos dias de hoje, o uso de certos recursos específicos que utilizamos no instituto e o trabalho com gêneros textuais em suportes diversos geraram insegurança, como será possível observar na análise. Creio que não só a demanda e a necessidade, mas também a vontade de muitos docentes de serem proficientes no uso de recursos tecnológicos são cada vez mais evidentes e esse é um assunto que não pode ser ignorado na formação de professores (o que também é discutido em CELANI, 2009b; PAIVA, 2012; CUNHA, 2016).

g. A inserção profissional no ensino. Não há dúvida de que as primeiras experiências assumindo uma sala de aula como professor de uma turma são muito marcantes. Segundo Marcelo (2009, p. 127), esse é o período tenso que exige a aquisição de conhecimento profissional e a manutenção de "um certo equilíbrio pessoal" no qual se realiza a "transição de estudantes a docentes".

Tenho algumas considerações adicionais a fazer sobre o último tópico, que entendo como cruciais quando pensamos na construção de identidades docentes. Acredito que, já no estágio, os licenciandos podem dar seus primeiros passos como professores e alguns poderiam ver esse período como o verdadeiro início na profissão. Entretanto, os estagiários vivem um processo muitas vezes angustiante, principalmente por não saber muito bem onde se encaixam no estágio, quais são suas atribuições, o que se espera deles e como se posicionar diante dos outros participantes. Eles enfrentam um dilema identitário em sua posição de entrelugar (MILLER, 2013; VALSECHI, 2016). Na preparação e apresentação da regência, por exemplo, eles têm que se desdobrar em professores, colegas, colaboradores, estagiários e alunos, mas, na verdade, eles 
muitas vezes se sentem 'à parte', como se 'fingindo ser professores', como mencionaram Elis e outros estagiários. Em uma das conversas com o grupo de colegas licenciandos, por exemplo, Elis levanta várias questões que a preocupavam, como a indefinição sobre o que era permitido a eles (estagiários) fazer/ser no estágio, o medo de ser tratada mal e a angústia quanto à visão dos professores regentes e alunos sobre ela. Esses comentários me motivam ainda mais a procurar "gerar reflexões investigativas sobre o sofrimento" (MILLER, 2013, p. 116) no período de pré-serviço e tentar entender, junto com Elis, esse processo de estágio na (re)construção de suas identidades, crenças e emoções.

\section{4 \\ Identidades, crenças e emoções}

Como explicado na introdução, ainda que o presente estudo se desenvolva a partir de uma visada das trajetórias identitárias de Elis como ponto de partida, estou ciente de que as (re)construções de identidades, crenças e emoções estão intimamente interligadas e esses construtos muitas vezes se sobrepõem. Contudo, nesta seção, trago considerações breves sobre crenças e emoções nas subseções 3.5.1 e 3.5.2., respectivamente, para logo depois discorrer sobre a inter-relação dinâmica entre identidades, crenças e emoções (BARCELOS, 2013; ARAGÃO; CAJAZEIRA, 2017), na subseção 3.5.3. Reitero, entretanto, que a divisão aqui exposta é feita somente na tentativa de apresentar esses construtos de forma organizada.

\subsection{1 \\ Crenças}

No Brasil, os estudos sobre crenças em relação ao ambiente pedagógico ganharam força a partir de meados dos anos de 1990, impulsionados principalmente pela busca de entender o que influencia as negociações de significados entre professores e alunos, bem como suas escolhas, ações e comportamentos. Assim, encontramos, dentro da Linguística Aplicada, pesquisas sobre o tema com diferentes focos, como, por exemplo, a relação entre crenças e ansiedade na aprendizagem de línguas estrangeiras (ROCHA SILVEIRA, 2012); crenças, motivação e ensino à distância (PERINE, 2013); e crenças e avaliações 
no contexto de ensino-aprendizagem de IFE (SOUZA, 2016), dentre muitos outros. Pesquisas como as aqui citadas lançam o olhar sobre as crenças nesses contextos considerando sua natureza dinâmica e complexa, diferentemente de alguns trabalhos que as aborda como estáticas e de uma forma unidirecional (BEDRAN; SALOMÃO, 2013).

Segundo Barcelos (2006), com os avanços nas pesquisas sobre crenças, seu conceito foi sendo reelaborado. Antes concebidas como estruturas mentais fixas e estáveis, desconectadas do conhecimento, as crenças são vistas atualmente não só como cognitivas, mas também diretamente influenciadas pelo social, pelas nossas experiências, podendo sofrer modificações (ibid.). Dessa forma, assim como as identidades (e muitas vezes de forma imbricada a essas), as crenças são socialmente construídas, sendo, portanto, dependentes dos contextos cultural e situacional. Elas emergem na interação e são frequentemente transformadas ao longo de nossas experiências.

Assim, considerando tudo o que foi descrito até agora nesta subseção, tomo como definição as palavras de Barcelos, que caracteriza crenças como "uma forma de pensamento, construções da realidade, maneiras de ver e perceber 0 mundo e seus fenômenos, coconstruídas em nossas experiências e resultantes de um processo interativo de interpretação e (re)significação" (BARCELOS, 2006, p.18). Portanto, o processo de formação de crenças é tanto individual (GIMENEZ, 2002), visto que cada pessoa traz consigo uma maneira de perceber a realidade, fruto de experiências passadas; quanto social e dinâmico, já que coconstruímos as crenças na interação com outros e novas experiências.

Desse modo, não 'colecionamos reflexos da realidade' durante a nossa vida, mas estamos continuamente interpretando nossas experiências e, a partir dessas impressões sobre o que vivenciamos, vai se construindo um sistema complexo e intricado de crenças (BARCELOS, 2007). Essa natureza complexa é contemplada por Rokeach (1968, apud BARCELOS, 2007), que explica que, dentro desse sistema de crenças, que forma uma rede de interconexões, é possível distinguir algumas que são mais centrais, de outras mais periféricas. Essas últimas podem referir-se às crenças sobre gosto, por exemplo, possuem poucas conexões com outras crenças e foram assimiladas mais recentemente.

As crenças mais centrais, por outro lado, têm mais ligações entre si e servem de base para que outras crenças sejam incorporadas. Algumas das características das crenças centrais são: (a) por serem mais interconectadas, elas se comunicam mais entre si, trazem mais consequências para outras crenças e são mais resistentes a mudanças; (b) estão mais interligadas ao 'eu' do indivíduo e às suas 
identidades; (c) geralmente são compartilhadas com outras pessoas; e (d) normalmente decorrem de nossas próprias experiências ao invés de algo que aprendemos a partir do que aconteceu com outros (ibid.). Seguindo esse pensamento, analiso que as crenças de Elis sobre 'ser professora', por exemplo, foram desenvolvidas e reformuladas durante muito tempo, sendo algumas muito mais difíceis de mudar por serem centrais, ou seja, por terem sido incorporadas mais cedo, estarem fortemente associadas "a emoções e identidades" e a outras crenças (BARCELOS, 2007, p. 118).

A análise de como as crenças emergem nos dados de Elis é importante porque, tal como Barcelos (2007), acredito que precisamos criar oportunidades para tomar consciência sobre essas crenças e refletir sobre elas e a sua conexão com o nosso agir. Existem três maneiras de entender a relação entre crenças com a prática (BARCELOS, 2006): na primeira, as ações são influenciadas pelas crenças, na segunda, crenças e ações se influenciam mutuamente na interação e, na terceira, a relação entre ação e crenças é vista como bem mais complexa, pois as ações dos professores não traduzem fielmente suas crenças. Corroboro com esta terceira noção, reiterando a necessidade de considerar os fatores contextuais como essenciais (BARCELOS, 2007), pois exercem grande influência em nossas decisões sobre o que fazer, em conjunto com nossas crenças e emoções.

\subsection{2 Emoções}

Sabendo que a emoção é "uma parte vital de ser professor" (COWIE, 2011, p. 236), o aspecto emocional torna-se relevante para o presente estudo, que tem como foco as (re)construções de identidades de uma licencianda durante seu estágio docente em IFE. O papel das emoções nessas (re)construções não é secundário ou eventual. Pelo contrário, elas fazem parte da constituição das identidades (ZEMBYLAS; SCHUTZ, 2009; COWIE, 2011; COELHO, 2011) de Elis e interferem em suas crenças, fazendo-as mais fortes ou enfraquecendo-as e até mesmo criando outras (ARAGÃO; CAJAZEIRA, 2017).

Recentemente, há um interesse crescente quanto ao papel das emoções dentro da área de LA no cenário internacional e no Brasil (FERREIRA; COELHO, 2014; ABREU, D., 2018). Nacionalmente, destaco os trabalhos que versam sobre a interação entre emoções, crenças e identidades (como BARCELOS, 2013 e 
2017; ARAGÃO; CAJAZEIRA, 2017; dentre outros) e nos contextos de ensino e aprendizagem de LE (tais como ARAGÃO, 2008 e ABREU, D., 2018, para citar alguns) e de formação de professores (como COELHO, 2011; OLIVEIRA, 2013 e BARCELOS, 2018, por exemplo), pontos que convergem com a presente pesquisa. As teses de Coelho (2011) e Oliveira (2013), por exemplo, mostram como as expressões de emoções de docentes podem ser transformadas a partir das experiências vividas nos contextos estudados. Em ambos os estudos, como também nesta tese, percebemos a defesa pela criação de espaços para o compartilhamento dessas experiências e emoções a fim de refletir sobre elas. Esse processo de acolhimento, de criação de "redes de apoio", espaços em que as pessoas possam se sentir à vontade para refletir conjuntamente sobre suas experiências, pode gerar mudanças em como nos sentimos, como também no sistema de crenças (ARAGÃO; CAJAZEIRA, 2017, p. 117).

Em consonância com esses estudos, parto do princípio de que nossas emoções, assim como as crenças e identidades, são desenvolvidas no dia-a-dia, de acordo com nossos sistemas de valores, nas relações com os outros. Logo, considero que as emoções, as identidades e as crenças, são "colaborativamente construídas e historicamente situadas" (ZEMBYLAS, 2003, p. 217). De fato, há um movimento recíproco entre os âmbitos individual e social, como pode ser observado nesta pesquisa, em que o desenvolvimento emocional de Elis, que ocorre em compasso com sua trajetória identitária, é influenciado e, ao mesmo, provoca mudanças em suas interações com os outros professores e alunos.

Portanto, a noção de emoções somente como fatores internos, disposições particulares e qualidades pessoais é refutada, posto que elas também são recursos sociais, culturais, históricos e políticos (ZEMBYLAS, 2005; REZENDE; COELHO, 2010; COELHO, 2011). Igualmente errônea é a habitual dicotomia entre razão e emoções, já que elas não estão em oposição, mas, na verdade, são interdependentes: razão e emoções se constituem mutuamente (ZEMBYLAS, 2005). Além disso, emoções não são estados passivos que nos invadem sem o menor controle (REZENDE; COELHO, 2010), mas são muitas vezes produzidas por nós e também funcionam como motivadores para o nosso comportamento e ação (ROBERTSON, 2004, apud BARCELOS, 2013). Essa dimensão ativa e que ultrapassa os limites pessoais é assinalada por Coelho e Durão (2017, p. 59) quando afirmam que

as emoções, assim, parecem fazer coisas. Agimos ao sentir, bem como ao não sentir, ou ao controlar as demonstrações do que sentimos, ou até a natureza mesma daquilo que sentimos. E esses sentires são regidos, como de há muito a antropologia das emoções advoga, não pelas flutuações do íntimo, não de maneira 
idiossincrática, mas por formas codificadas e perpassadas por códigos morais e convicções ético-politicas, que prescrevem, avaliam, condenam, exigem e até mesmo proscrevem reações emocionais.

Desse modo, as emoções não são estáticas, mas se desenvolvem como um processo que está em constante construção em um sistema complexo, que se desenrola nas relações com os outros, nos diferentes contextos (BARCELOS, 2013) e, de acordo com Zembylas (2005), até mesmo na forma que expressamos nossas emoções e acabamos por gerar outras. Assim, a emoção é vista aqui como uma prática discursiva (ABU-LUGHOD; LUTZ, 1990 apud ZEMBYLAS, 2004) na qual os relacionamentos, valores e relações de poder influenciam profundamente como e quando emoções são construídas, expressas e comunicadas (ZEMBYLAS, 2005; COELHO; DURÃO, 2017).

De tudo o que foi dito, podemos depreender que as emoções possuem muitas particularidades que contradizem acepções comumente aceitas em nossa sociedade. Assim, ao invés de delimitá-las com uma definição fechada, apresentei algumas de suas características em consonância com Barcelos (2013, p. 165167), que as resume da seguinte forma: as emoções são ativas; interativas e processuais; estruturadas hierarquicamente em um sistema complexo; e culturalmente, socialmente e discursivamente constituídas.

\subsection{3 \\ (Re)construções de identidades-crenças-emoções}

Trazendo toda a discussão sobre identidade, crenças e emoções para a presente pesquisa, considero que o estágio não é um período de treinamento ou simples observação, mas de elaboração conjunta de conhecimentos sobre a prática pedagógica e que as identidades, construídas e negociadas na interação (MOITA LOPES, 2003), bem como as diferentes crenças (KUDIESS, 2005; BARCELOS, 2007; OLIVEIRA; BARCELOS, 2012) e emoções (ZEMBYLAS, 2005; COELHO, 2011; ARAGÃO; CAJAZEIRA, 2017) se relacionam com as ações dos participantes, sofrem influências do contexto e podem ser reelaboradas nesse espaço.

Tal reelaboração é notada nas participações de Elis aqui analisadas, como poderá ser visto no capítulo 6. Percebemos, por exemplo, como alguns dos mitos sobre IFE listados no capítulo 2 (seção 2.1.3.), além de outras crenças de Elis sobre o estágio e as concepções sobre si mesma, sua insegurança e sua 
preocupação na relação com os outros são retomados nas interações de forma sobreposta, sendo muitas dessas crenças e emoções, que também constituem suas identidades, (re)construídas à medida em que ela avança em sua trajetória identitária.

Assim, entendo que estamos continuamente nos autoconstruindo e construindo os outros na interação a partir de nossas identidades, emoções e crenças, pois, "como seres sociais, estamos sempre em movimento no processo de vir a ser socialmente" (FABRÍCIO; MOITA LOPES, 2002, p. 16) utilizando o que já temos (quem estamos sendo, em que acreditamos e o que sentimos) em negociação direta com o contexto.

Por conseguinte, assim como as identidades, também negociamos nossas crenças, de tal maneira que essas últimas são consideradas como parte de nossa construção identitária (BARCELOS, 2006; OLIVEIRA; BARCELOS, 2012). Do mesmo modo, segundo Barcelos (2013, p. 174-175), as emoções também se relacionam com nossas crenças, sendo essas últimas influenciadas de quatro formas principais, a saber: a) as emoções provocam alterações nas imagens que formamos em nosso cérebro e nas operações mentais, mudanças corporais preparatórias e comportamento resultantes; b) emoções ratificam e oferecem evidência para as crenças; c) elas conduzem a atenção para uma informação específica; e d) as emoções podem criar novas crenças ou alterar as existentes de forma a "aumentar ou diminuir a força que uma crença é defendida" (FRIJDA et al., 2000 apud BARCELOS, 2013) fazendo-as mais ou menos resistentes à mudança.

Além de estarem fundamentalmente interligadas às crenças (BARCELOS; RUOHOTIE-LYHTY, 2018), as emoções são centrais na constituição das identidades, principalmente por serem as responsáveis por atribuir significado às experiências (ZEMBYLAS, 2003). Novamente, essa relação é complexa, envolvendo uma multiplicidade de emoções em interação entre si, bem como com diferentes identidades que emergem e estão em negociação em um dado evento, influenciadas pelos contextos e as relações de poder (ZEMBYLAS, 2005, BARCELOS, 2013). Nessa perspectiva, identidades são entendidas como processos dinâmicos "de discursos intersubjetivos, experiências e emoções" (ZEMBYLAS, 2003, p. 221), estando todos eles em constante mudança e sofrendo influência das nossas crenças. Dessa forma, considero que estamos sempre em um movimento de "tornar-nos", reiterando a definição de identidade como um 
projeto impossível de completar $^{19}$, como explicado na seção 3.1 do presente estudo.

Portanto, tendo em vista a interação desses três construtos de forma imbricada, como descrita nessa subseção, concordo com Barcelos (2013, p.177) quando diz que "talvez possamos falar em emoções-crenças-identidades em prática": todos esses conceitos estão inerentemente ligados e são responsáveis pela formação um do outro, são desenvolvidos ao longo de nossas vidas, em nossas experiências, nas interações, e são constantemente reconstruídos por meio de nossas vivências passadas e presentes, bem como pelos contextos. No próximo capítulo, discuto como as identidades emergentes de Elis, entretecidas por suas crenças e emoções, serão analisadas a partir de um prisma sociossemiótico.

${ }^{19}$ Conforme Bauman (2005). 


\section{4 \\ A construção discursiva de identidades a partir de uma perspectiva sociossemiótica}

Two roads diverged in a yellow wood,

And sorry I could not travel both

And be one traveler, long I stood ${ }^{20}$

(FROST,1916)

Neste capítulo, prossigo a fundamentação teórica com foco nas escolhas feitas por Elis em seus textos, inevitavelmente eliminando outras e contribuindo para a sua caminhada identitária. Essas escolhas podem ser descritas pela Linguística Sistêmico-Funcional (HALLIDAY, 1994; HALLIDAY; MATTHIESSEN, 2014; THOMPSON 2014a; EGGINS, 2004), doravante LSF, que oferece um arcabouço teórico e instrumentos de análise que permitem investigar a linguagem a partir da situação em que ela é produzida (levando em conta quem a produz e como, onde, quando e para quem) e compreendê-la a partir da função que desempenha naquele contexto.

A LSF também se mostra muito profícua para esta investigação por ser um campo híbrido e "INdisciplinar" (MOITA LOPES, 2006a; 2009) que está inserido na Linguística Aplicada e que estuda a linguagem em todas as formas que ela se apresenta, não se limitando a investigar a criação de significados apenas do estrato linguístico (SCHLEE; NÓBREGA; VIAN JR, no prelo). Outro aspecto relevante para a adoção da LSF na presente pesquisa foi o fato de que esse prisma, assim como o arcabouço pelo qual identidades são aqui entendidas, parte do social e considera que os significados são construídos "no discurso durante as interações sociais, de acordo com aspectos contextuais específicos a cada interação" (NÓBREGA, 2009, p. 90).

Portanto, para a LSF, a linguagem é semântica, semiótica, funcional e contextual (EGGINS, 2004), ou seja, ela é concebida como um sistema capaz de produzir significados a partir de escolhas em um eixo paradigmático (nos níveis semântico, lexicogramatical e da expressão) à nossa disposição para a interação e está diretamente relacionada às funções que deve servir dentro do contexto em que esses significados são negociados. Ao fazer opções dentro do sistema para construir um texto, descartamos possibilidades que não serviriam a nossos propósitos em um dado contexto (GOUVEIA, 2009). Assim, a linguagem e o

20 Duas estradas divergiam em um bosque amarelo, e pesaroso por não poder viajar por ambas e ser um só viajante, por muito tempo ali fiquei. 
contexto são interdependentes: aos falantes é oferecido um conjunto de significados potenciais em um dado contexto situacional e cultural, que determina e molda tais escolhas e é ao mesmo tempo influenciado por elas (FUZER; CABRAL, 2014).

Partindo dessa premissa, há uma relação sistemática entre a organização da linguagem e a organização do contexto como uma via de mão dupla. Do mesmo modo que ocorre ativação em cadeia a partir do extralinguístico passando pelos diferentes níveis até o da expressão, as escolhas neste nível vão construir novos significados passando pelas camadas da lexicogramática e do sistema semântico-discursivo, até retornar ao contexto. Assim, conhecendo o contexto podemos prever probabilisticamente como o texto representará o contexto linguisticamente. Igualmente, conhecendo a materialização linguística (o texto) podemos deduzir o contexto no qual ele foi produzido (EGGINS, 2004).

O contexto de situação está associado às escolhas linguísticas e engloba o propósito, o conteúdo, as condições e o contexto de produção bem como a interação dos participantes no evento comunicativo. Esse contexto imediato está inserido em ambiente mais amplo que abrange os conhecimentos compartilhados da comunidade discursiva e orienta a atividade social, o contexto de cultura. A figura 4, apresentada a seguir, é uma adaptação a partir de Halliday e Matthiessen (2014) e Martin e Rose (2007) que mostra como os níveis de estratificação da linguagem estão organizados de acordo com a LSF.

Figura 4 - Estratificação da linguagem

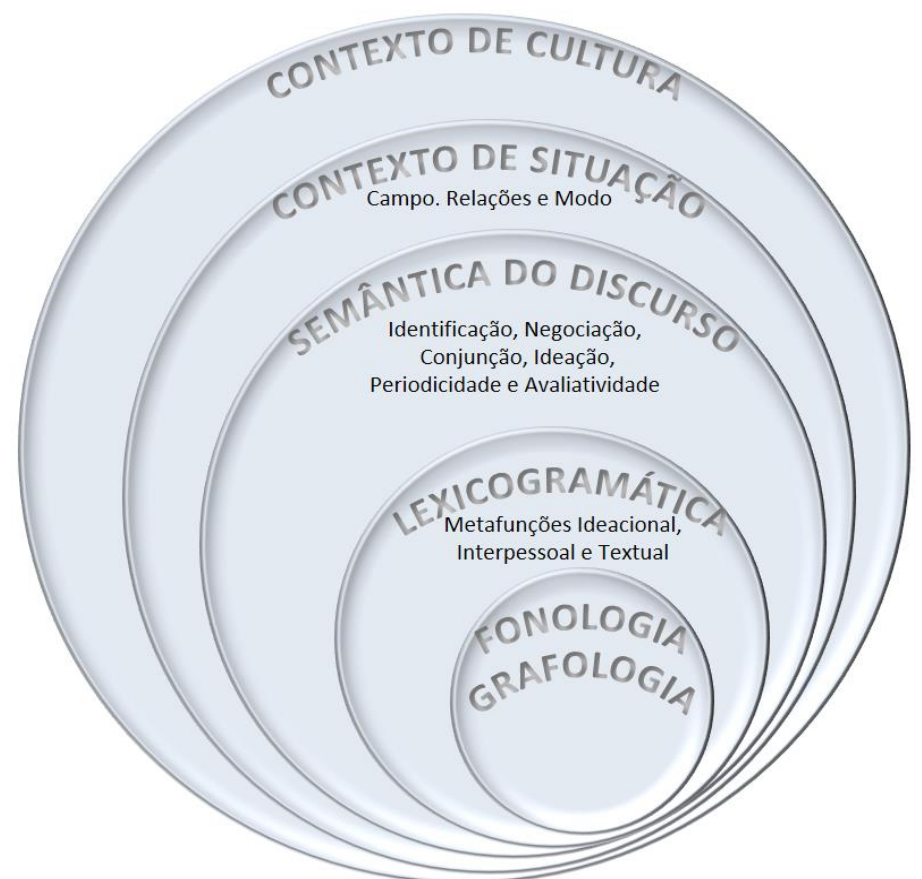

Fonte: Adaptada de Halliday e Matthiessen (2014) e Martin e Rose (2007) 
Os dois círculos externos representam o contexto e os três centrais, a linguagem. Assim, podemos perceber que o nível de abstração aumenta à medida que avançamos pelos estratos de dentro para fora. De acordo com Eggins (2004), o conceito de contexto de situação, originalmente proposto por Malinowski, e posteriormente desenvolvido por Firth, foi retomado e reestruturado por Halliday, que o descreve por meio de três variáveis: campo, relações e modo. A variável campo se relaciona ao tipo de atividade social, propósito comunicativo e ao assunto que está sendo desenvolvido no momento da interação. A variável relações, por sua vez, diz respeito às pessoas envolvidas no evento comunicativo, seus papeis sociais e como elas se relacionam entre si. A variável modo trata da forma como a comunicação ocorre, ou seja, como a linguagem está sendo usada.

Dentro do estrato da lexicogramática, e ligadas às variáveis discutidas, estão as três metafunções que Halliday apresenta para examinar os sistemas internos da linguagem sob o foco das funções sociais (HALLIDAY; HASAN, 1989): ideacional, interpessoal e textual. A metafunção ideacional se relaciona à variável campo e engloba as conexões existentes entre nossas ideias, como também abrange o conteúdo interno das representações do mundo, podendo ser estudada por meio do sistema de transitividade. Tal sistema constrói as representações de nossas experiências (incluindo emoções e crenças) por meio de processos, como será explicado na seção 4.1. A metafunção interpessoal está ligada à variável relações e é formada pelos sistemas de modo e modalidade. $O$ sistema de modo se ocupa dos papeis dos participantes da interação e o de modalidade descreve os posicionamentos dos participantes em relação aos outros. Finalmente, a metafunção textual, que parte da variável modo, se ocupa do uso da linguagem na organização do texto, ou seja, como a mensagem é construída e a informação distribuída, sendo articulada em tema e rema. O primeiro é o ponto de partida da oração, enquanto o segundo é aquilo que se diz sobre o tema.

Essas metafunções ocorrem simultaneamente nos textos, mas, no presente estudo, o enfoque recairá principalmente nas metafunções ideacional e interpessoal para tentar entender a trajetória identitária de Elis a partir da análise de como ela concebe o processo de estágio em si (como suas experiências emergem nos dados e como ela escolhe mostrar os participantes, inclusive ela mesma) e como as relações entre esses participantes são expressas nas orações. 
A representação das metafunções no nível da lexicogramática e algumas de suas subdivisões encontram-se na figura 5.

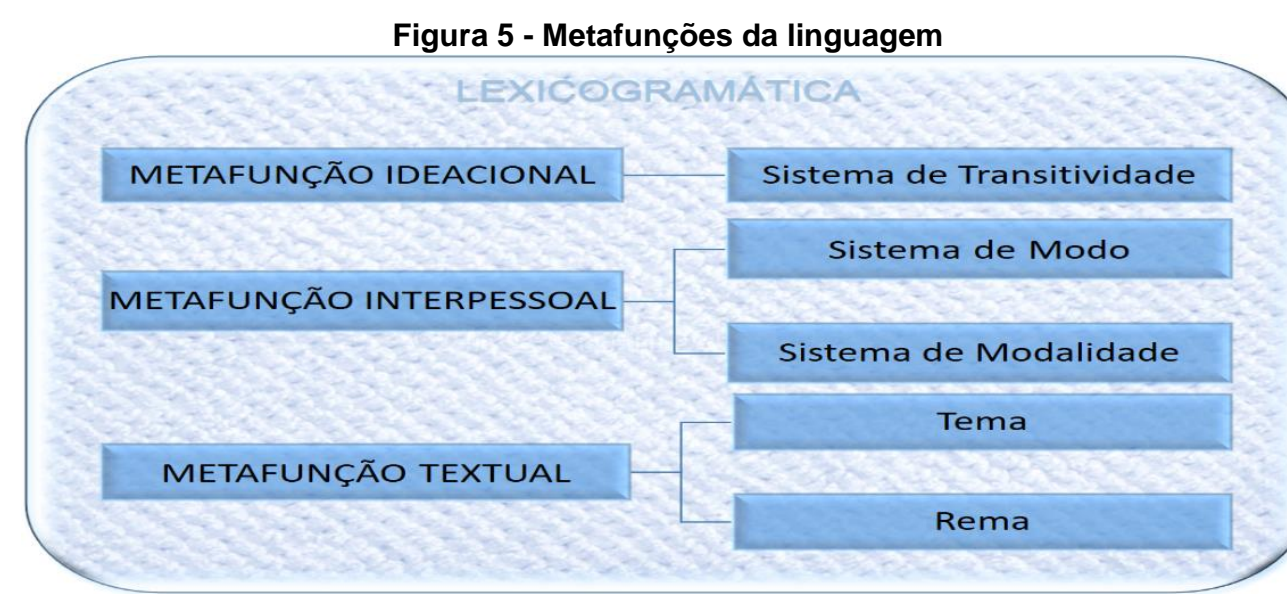

Fonte: Figura de minha autoria, elaborada a partir de Halliday e Matthiessen (2014)

O estrato da semântica discursiva, que se preocupa com os significados para além da oração, compreende seis sistemas que ocorrem concomitantemente (MARTIN; ROSE, 2007, p. 17), a saber: Identificação (que trata de como as pessoas, coisas e lugares são introduzidos nos textos e como elas podem ser rastreadas posteriormente nos mesmos), Negociação (como os turnos são organizados em trocas de bens, serviços e informações), Conjunção (como os eventos e os estados das coisas estão conectados uns aos outros em termos de tempo, causa, contraste e similaridade), Ideação (que tem como foco os tipos de atividades realizadas pelos participantes do discurso, seu conteúdo e como eles são descritos), Periodicidade (indica o fluxo das informações, ou seja, como os significados são organizados textualmente) e Avaliatividade (concentra-se na forma como a avaliação e a perspectiva emergem nos textos. Como acontece no nível lexicogramatical, esses sistemas estão inter-relacionados. Trago o foco para o Sistema de Avaliatividade neste estudo por sua relevância na busca de criar inteligibilidades sobre o contexto de estágio em nossa comunidade de prática de IFE a partir das avaliações, posicionamentos e perspectivas de Elis.

A figura 6 tem como objetivo destacar os construtos que serão foco de minha análise (Sistema de Avaliatividade e Metafunções Ideacional e Interpessoal, que estão demarcados por caixas). Assim, represento a inter-relação entre os estratos da linguagem no que tangem os significados ideacionais, interpessoais e textuais, como proposto por Martin e White (2005, p.12), mas aqui destaco apenas o contexto de situação, a semântica do discurso e a lexicogramática. Desse modo, podemos perceber que, no nível das negociações de significados interpessoais, por exemplo, a metafunção interpessoal (no nível da lexicogramática) está em 
conexão direta com o Sistema de Avaliatividade (na semântica do discurso) e com a variável relações (considerando-se o contexto situacional).

Figura 6 - Inter-relação entre estratos da linguagem

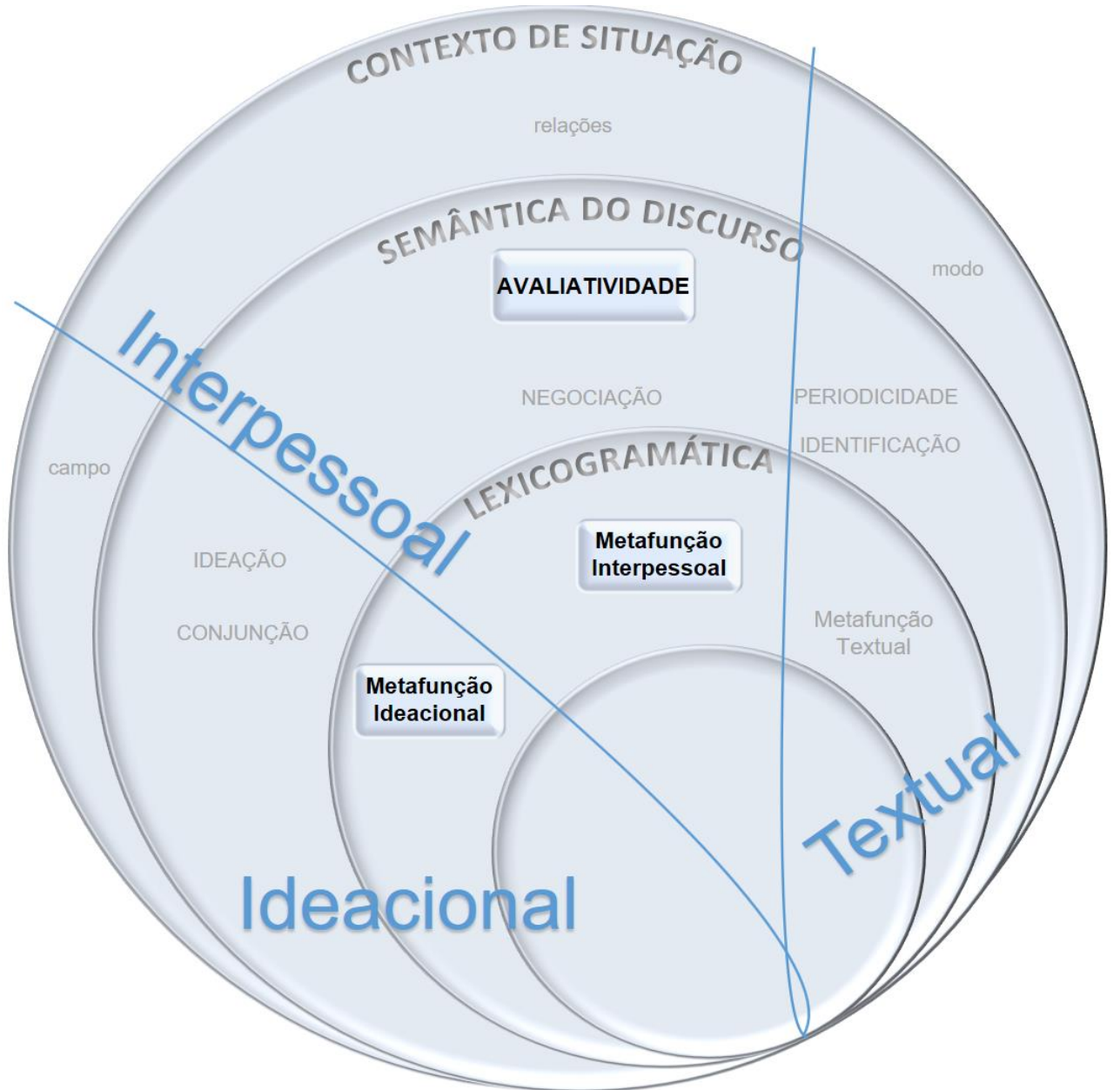

Fonte: Figura de minha autoria, elaborada com base em Martin e White (2005)

Desse modo, a partir das escolhas lexicogramaticais (ideacionais e interpessoais) e semânticas (pelos elementos avaliativos) acredito que será possível analisar as (re)construções identitárias de Elis durante o estágio. Entretanto, é essencial ressaltar que, apesar de estar ciente da enorme gama de possibilidades de análise oferecidas pela LSF, vou me ater apenas a algumas de suas categorias e subcategorias que julgo relevantes para a proposta desta tese. Além disso, tomo a decisão de avançar apenas até certo ponto dentro dos níveis de delicadeza (delicacy), sabendo que, inevitavelmente, muitos detalhes serão deixados de fora.

\section{1}




\section{A representação das experiências da licencianda na oração: a metafunção ideacional}

A metafunção ideacional é usada para representarmos na linguagem nossas experiências do mundo por meio do Sistema de Transitividade. Por esse sistema focalizamos o conteúdo interno da oração a fim de observar que processos (os grupos verbais que representam o que está acontecendo, que significados estão se desenrolando) foram utilizados e, a partir deles, determinar quem são os participantes incluídos nas interações e em que circunstâncias uma proposição ocorre (THOMPSON, 2014a). Com base nele, será possível analisar como Elis constrói a sua interpretação de suas experiências, identidades, crenças e emoções em suas escolhas lexicogramaticais.

Segundo Halliday e Matthiessen (2014) existem três tipos principais de processos (materiais, mentais e relacionais). Entre esses processos existem outros três que compartilham características comuns com seus fronteiriços. Entre os processos mentais e materiais temos os processos comportamentais. Já entre os materiais e relacionais encontram-se os existenciais. Os processos verbais estão entre os mentais e relacionais. Na verdade, não existe um limite específico traçado entre esses processos, mas uma sobreposição entre seus extremos, que dão a noção de continuidade, entrelaçamento e difusão, como visto na figura 7.

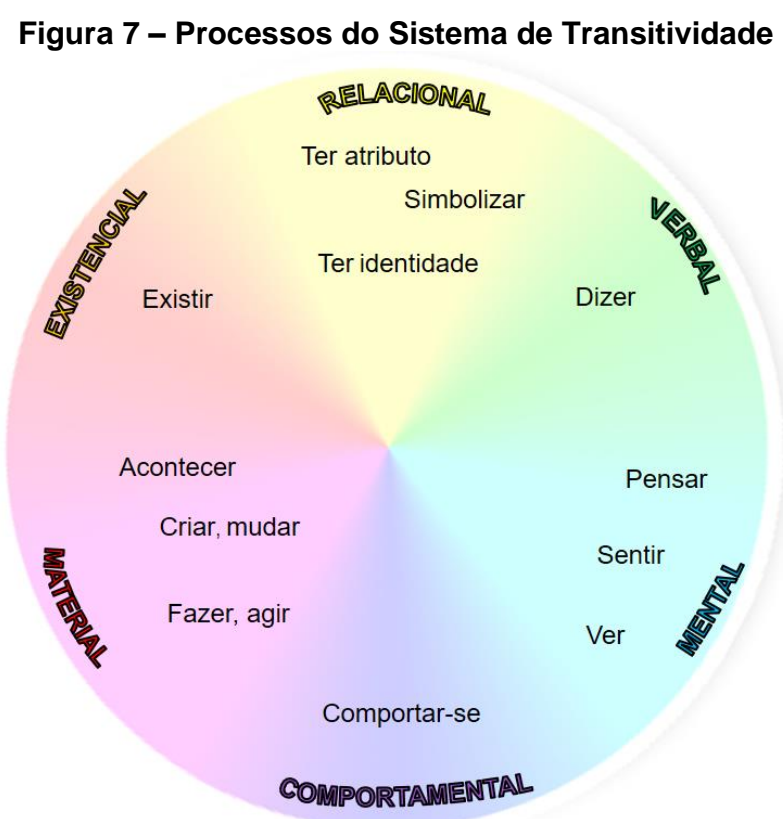

Fonte: Adaptado de Halliday e Matthiessen (2014, p. 172)

Cada um desses tipos de processos (grupos verbais) tem pelo menos um participante (grupo nominal) e pode ser, ou não, acompanhado por circunstâncias, 
mas, como já explicado na introdução deste capítulo, não vou fazer uma análise detalhada de cada uma das realizações, pois acredito que tal categorização não corresponde ao objetivo deste estudo. Em função disso, para concluir esta subseção, vou me restringir à breve descrição de cada um dos processos.

Os processos materiais representam um "fazer" físico no mundo exterior e estão relacionados às ações propriamente ditas, enquanto os processos mentais são relativos à representação do nosso interior, ou seja, ao que pensamos, sentimos, desejamos e como percebemos o mundo. Os processos relacionais, por sua vez, representam significados ligados à identificação, à classificação e à posse. Os processos existenciais mostram o reconhecimento da existência de algo e os processos verbais expressam o que comunicamos, o que dizemos. Por fim, os processos comportamentais representam o comportamento humano e o que se liga ele. O quadro 1 busca resumir os tipos de processo de acordo com Halliday e Matthiessen (2014) acrescido de exemplos dos dados de Elis.

\section{Quadro 1 - Tipos de processo}

\begin{tabular}{|c|c|c|}
\hline Processos & Significado & Exemplos dos dados da pesquisa \\
\hline MATERIAL & 'fazer, criar' & $\begin{array}{l}\text { "Já preparamos alguns materiais de apoio." } \\
\text { "Escrevi um script com as minhas falas' }\end{array}$ \\
\hline MENTAL & $\begin{array}{l}\text { 'perceber, sentir, } \\
\text { pensar' }\end{array}$ & $\begin{array}{l}\text { "Pude refletir um pouco sobre o funcionamento de uma } \\
\text { escola" } \\
\text { "Não pensei que poderia ensinar" }\end{array}$ \\
\hline RELACIONAL & 'ser' & $\begin{array}{l}\text { "Os alunos, em sua maioria, eram bastante participativos e } \\
\text { sempre estavam engajados com as atividades propostas" } \\
\text { "Sou grata porque tive uma boa experiência" }\end{array}$ \\
\hline COMPORTAMENTAL & $\begin{array}{l}\text { 'comportar-se } \\
\text { fisiológica e } \\
\text { psicologicamente' }\end{array}$ & $\begin{array}{l}\text { "Conversamos sobre minha avaliação" } \\
\text { "Assisti a uma oficina sobre produção de material didático" }\end{array}$ \\
\hline VERBAL & 'dizer' & $\begin{array}{l}\text { "Não sei dizer se eu teria tido uma experiência equivalente } \\
\text { em outros colégios" } \\
\text { "Falaria, talvez, das minhas próprias experiências" }\end{array}$ \\
\hline EXISTENCIAL & 'existir, acontecer' & $\begin{array}{l}\text { "Há projetores em algumas salas, em outras não, em } \\
\text { algumas encontramos computadores, mas, não existem } \\
\text { projetores" } \\
\text { "Houve um esforço real da minha parte" }\end{array}$ \\
\hline
\end{tabular}

Fonte: Elaborado com base em Halliday e Matthiessen (2014)

$\mathrm{Na}$ análise dos dados nesta tese, algumas vezes vou me referir ao tipo de processo e quais participantes foram selecionados nas orações produzidas por Elis em um determinado contexto. Entretanto, tais referências serão feitas somente quando se mostrarem relevantes para a discussão sobre as (re)construções de identidades, crenças, emoções no estágio em IFE em nossa comunidade de prática. Da mesma forma, em certos momentos, citarei algumas das opções da licencianda dentro da metafunção interpessoal, da qual destaco 
alguns conceitos para utilização neste estudo, como pode ser visto na próxima subseção.

\section{2}

\section{A negociação de significados na oração: a metafunção interpessoal}

Um dos principais objetivos de se comunicar é negociar significados e, nesse processo, tanto o escritor/falante quanto o leitor/ouvinte assumem papeis na interação: os primeiros dão algo ou demandam alguma coisa de seu interlocutor e os segundos aguardam uma resposta verbal ou física (HALLIDAY; MATTHIESSEN, 2014). Além dos papéis principais de dar e demandar, é importante fazer a distinção quanto à natureza do que está sendo trocado: bense-serviços ou informação (ibid.). A função semântica da oração em uma troca de informação é uma proposição, algo que pode ser debatido (negado, confirmado, aceito com reservas, duvidado, etc.), enquanto em uma troca de bens-e-serviços ela é uma proposta (Halliday, 1994, p. 70 e 71).

Segundo Thompson (2014a), nas trocas de informação, a linguagem tem função constitutiva, ou seja, ela é a responsável pelo processo. Nas trocas de bens-e-serviços, por outro lado, a linguagem tem um papel auxiliar, posto que em pelo menos parte da troca ela não é necessária (como no caso de uma ordem, cuja resposta sempre envolve uma ação). Essas variáveis (dar ou demandar e bens-e-serviços ou informação), quando combinadas, definem quatro funções principais do discurso: oferta, ordem, afirmação e pergunta. No quadro 2, apresento essas quatro funções com exemplos de falas de Elis retiradas dos dados gerados.

\begin{tabular}{|c|c|c|c|}
\hline \multicolumn{4}{|c|}{ Quadro 2 - Funções discursivas } \\
\hline & & $\begin{array}{l}\text { Bens-e-serviços } \\
\text { PROPOSTA }\end{array}$ & $\begin{array}{c}\text { Informação } \\
\text { PROPOSIÇÃO }\end{array}$ \\
\hline \multirow{2}{*}{ 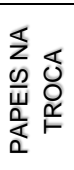 } & DAR & $\begin{array}{c}\text { 'oferta' } \\
\text { Quer ajuda? }\end{array}$ & $\begin{array}{c}\text { 'afirmação' } \\
\text { Agora vai me dar mais nervoso. }\end{array}$ \\
\hline & DEMANDAR & $\begin{array}{c}\text { 'ordem' } \\
\text { Tira essa figura. }\end{array}$ & $\begin{array}{c}\text { 'pergunta' } \\
\text { Onde que a gente se encaixa aqui? }\end{array}$ \\
\hline
\end{tabular}

Fonte: Elaborado com base em Halliday e Matthiessen (2014)

Nesses exemplos, podemos perceber como linguagem é usada em sua função básica de negociação de significados e se apresenta como uma rede de escolhas dentro dos sistemas de modo e de modalidade, bem como em níveis de polaridade (HALLIDAY; MATTHIESSEN, 2014). Para a análise de como Elis 
negocia suas opiniões, torna-se importante observar suas escolhas dentro do sistema de modalidade, que é uma área complexa pela qual o escritor/falante pode se inserir em seu discurso "expressando atitudes e julgamentos de vários tipos" (EGGINS, 2004, p. 172).

Para Thompson (2014a), de forma simplificada, a modalidade se refere ao intervalo entre o "sim" e o "não". Deste modo, o falante/escritor pode mostrar sua opinião fazendo uma escolha entre os graus intermediários que existem entre os polos positivo e negativo usando diferentes recursos, como representado na figura 8, adaptada de Halliday e Matthiessen (2014, p. 619), que mostra algumas formas de modalidade em sua relação com a polaridade.

Figura 8 - Relação entre modalidade e polaridade

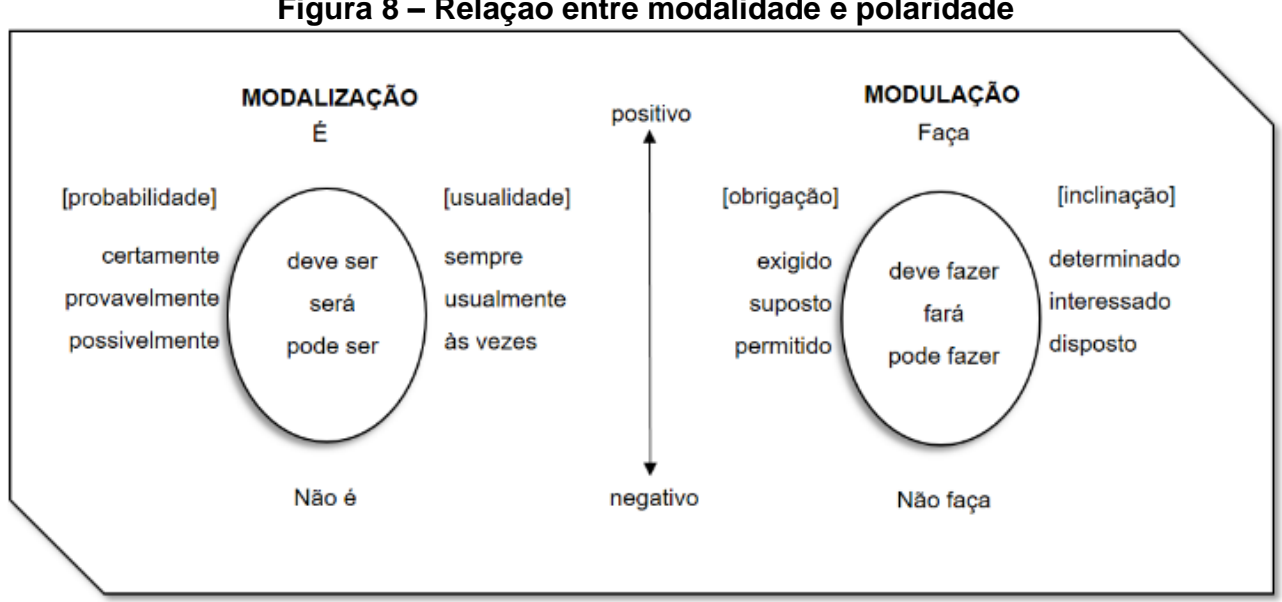

Fonte: Adaptado de Halliday e Matthiessen (2014, p. 619)

Como podemos ver na figura 8, Halliday e Matthiessen (2014) subdividem o sistema de modalidade em modalização e modulação, sendo a primeira referente a graus de frequência e probabilidade em proposições (trocas de informações); e a segunda a graus de obrigação (em ordens) ou graus de inclinação (em ofertas) em propostas. Para analisar essas escolhas, observarei não somente o finito (o grupo verbal) como em 'pode' e 'deve', os adjuntos modais (como, por exemplo, 'provavelmente' e 'talvez') e expressões como 'é possível' e 'é esperado', mas também as metáforas gramaticais como 'acho que' e 'penso que', que fazem parte da modalidade. É importante frisar que meu objetivo não é classificar o tipo de modalidade observado, mas de tornar claro o efeito de seu uso nos dados. Chamo a atenção ainda para o fato de que utilização de qualquer tipo de modalidade faz com que a nossa escrita/fala seja menos assertiva do que uma oração não modalizada (HALLIDAY; MATTHIESSEN, 2014). Assim, dizer "Tenho certeza absoluta de que ele não fez isso" mostra menos certeza do que dizer "Ele não fez isso". 
Nesta seção, apresentei as metafunções ideacional e interpessoal ${ }^{21}$ de forma muito simplificada e limitada, fruto de minhas escolhas dentro do aparato enormemente complexo e sofisticado oferecido pela LSF. A seguir, passo a discorrer sobre o Sistema de Avaliatividade, a partir do qual será possível investigar como Elis negocia avaliações, se posiciona e expõe suas opiniões nos dados gerados.

\section{3}

\section{O Sistema de Avaliatividade}

$\mathrm{Na}$ interação, estamos constantemente fazendo escolhas entre os diversos recursos que a língua nos oferece para avaliar o que incluímos em nossos textos, sinalizando para o leitor/ouvinte nossas atitudes quanto ao que expressamos. Partindo da perspectiva sistêmico-funcional da linguagem, a Avaliatividade leva a análise para além da oração (MARTIN; WHITE, 2005) e é um dos sistemas responsáveis pelos significados interpessoais no nível da semântica do discurso. Cabe mencionar que esse sistema, assim como a LSF, foi inicialmente elaborado para a língua inglesa e foram necessários o trabalho e a dedicação de pesquisadores brasileiros para adaptar ambos ao contexto brasileiro e às características de nossa língua (FUZER; CABRAL, 2014; VIAN JR.; SOUZA, 2017; ALMEIDA; VIAN JR, 2018).

Com base no Sistema de Avaliatividade será possível examinar a avaliação e a perspectiva de Elis por meio da categorização de suas ocorrências nos textos por ela produzidos e nas interações gravadas em áudio, que fazem parte dos dados gerados para esta tese. O sistema é dividido em três subsistemas presentes simultaneamente no texto: atitude, gradação e engajamento, como representado na figura 9 , a seguir.

21 Para uma discussão mais aprofundada e detalhada sobre as metafunções ideacional e interpessoal, ver Halliday e Matthiessen (2014, capítulos 4 e 5) e Thompson (2014a, capítulos 4 e $5)$. 
Figura 9 - Os subsistemas da Avaliatividade

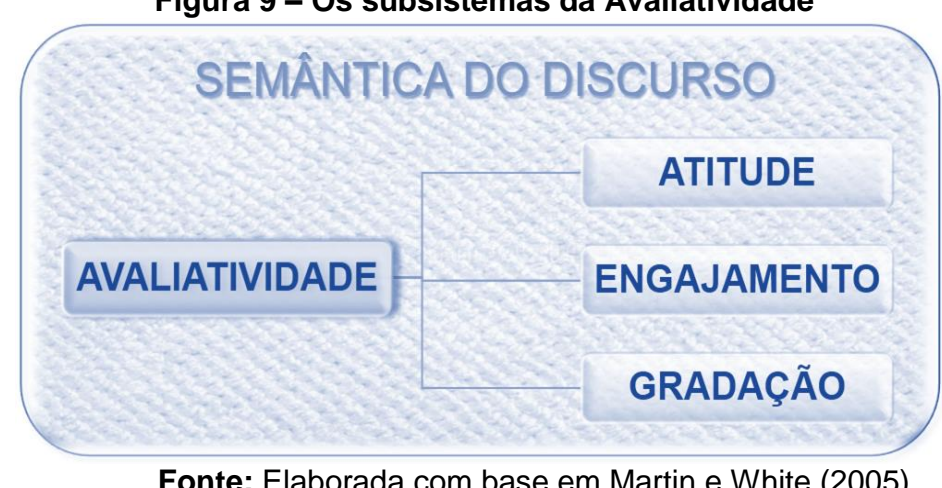

Fonte: Elaborada com base em Martin e White (2005)

Sabendo que as identidades são "remodelada[s] e disciplinada[s] pelos discursos e práticas de emoção"22 (MEYER, 2009, p. 79), a análise do sistema de atitude se torna importante para esta pesquisa. Com o auxílio desse sistema, será possível analisar, "como os interlocutores estão sentindo, os julgamentos que fazem e o valor que colocam nos vários fenômenos da sua experiência"23 (MARTIN, 2000, p.144). Deste modo, poderei entender como Elis se expressa por meio de respostas emocionais; reconhecer o que ela avalia (objeto, situação, fato, evento ou pessoa) e como o faz; se suas escolhas atitudinais são mostradas de forma positiva ou negativa; e se são explicitas (inscritas) ou estão subentendidas (evocadas).

Segundo Martin (2000), as categorias de atitude são o afeto, o julgamento e a apreciação, sendo apenas uma delas escolhida por vez. O afeto, que trata dos recursos usados na construção das emoções no texto, é a categoria central da atitude, sendo recontextualizado como julgamento (quando expressamos o que sentimos quanto ao comportamento de outros) e apreciação (quando expressamos o que sentimos quanto a coisas). Em outras palavras, essas subcategorias ocupam-se, respectivamente, das emoções, da ética e da estética, mas todas são formas de expressar o que sentimos (NÓBREGA, 2009). Dessa forma, entendo que o afeto permeia todas as escolhas atitudinais.

Segundo Martin e White (2005), o afeto é expresso por meio de uma diversificada gama de estruturas e eles se apoiam em Halliday (1994) para explicar como essas realizações ocorrem lexicogramaticalmente como 'qualidades' (pela modificação de participantes e processos), como 'processos' e como 'comentários' (pelo uso de adjuntos modais, por exemplo), sendo esses três também realizados metaforicamente. Assim, os significados de afeto também

22 No original: Identity becomes reshaped and disciplined through discourses and practices of emotion.

${ }^{23}$ No original: how the interlocutors are feeling, the judgements they make, and the value they place in the various phenomena of their experience. 
podem ocorrer de forma menos congruente, ou seja, mais obscura ou menos óbvia, por meio de metáforas gramaticais, pelo uso de nominalizações e consequente empacotamento de informações, por exemplo (HALLIDAY; MATTHIESSEN, 2014).

Para classificar o afeto, Martin e White (2005, p. 46-52) recorrem a seis premissas/fatores ${ }^{24}$, apresentados a seguir:

a. se os sentimentos são construídos como positivos ou negativos pela cultura popular;

b. se os sentimentos se realizam como uma "onda de emoção" (envolvendo algum tipo de manifestação paralinguística ou extralinguística) ou se eles são experienciados internamente como um tipo de estado emotivo ou processo mental;

c. se os sentimentos são uma reação a um estímulo específico ou estado de espírito geral, geralmente sendo difícil explicar o porquê do sentimento;

d. como os sentimentos são graduados a partir de uma escala de intensidade (baixa, média, alta);

e. se os sentimentos envolvem intenção (ao invés de uma reação) em relação a algo que ainda não ocorreu ou a um estímulo que já se realizou;

f. as emoções podem ser organizadas em três grandes grupos de sentimentos: in/felicidade para assuntos do coração (como tristeza, ódio, felicidade); in/segurança, que se relaciona ao bem-estar socialmente construído no ambiente (como os sentimentos de ansiedade e confiança); e in/satisfação, que engloba emoções que dizem respeito ao telos, à busca de objetivos (como as sensações de curiosidade e respeito).

O julgamento trata das avaliações morais do comportamento humano. Aprovamos ou condenamos o que as pessoas fazem a partir das expectativas que temos sobre como agir em nossa cultura e essas avaliações podem estar orientadas de acordo com sanções sociais ou lidar com a estima social. Os julgamentos de sanção social se subdividem em veracidade e propriedade,

24 Alguns desses fatores são fundamentados na gramática sistêmico-funcional (HALLIDAY; MATTHIESSEN, 2014). 
enquanto os de estima social podem ser de normalidade, tenacidade e capacidade.

A apreciação, que se subdivide em reação, composição e valor, é o campo dos significados usados para construir avaliações dos produtos feitos pelo homem, fenômenos naturais e estados de coisas. Os casos em que as qualidades estéticas de pessoas são examinadas serão também classificados como apreciação por serem avaliadas como objetos (em contraste com os exemplos em que se analisa o comportamento dessas pessoas, o que seria julgamento). $\mathrm{Na}$ figura 10, mostro uma visão geral das categorias de atitude.

Figura 10 - Representação da relação entre afeto, apreciação e julgamento

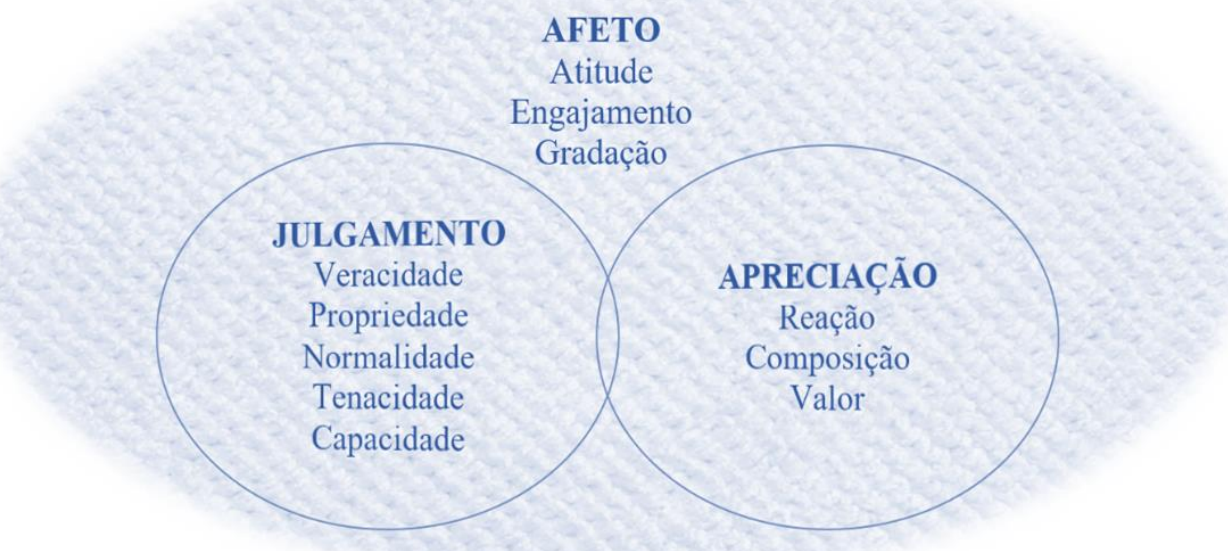

Fonte: Figura de minha autoria, elaborada com base em Halliday e Matthiessen (2014)

Como podemos ver na representação de como as três categorias de atitude se relacionam, na figura 10 , o afeto permeia todas as nossas escolhas, mas, a classificação em uma das três categorias será feita aqui com base na "fonte e na direção da avaliação" (THOMPSON, 2014b, p. 53). Assim, considerarei como afeto avaliações de emoção advindas e experienciadas pela(s) mesma(s) pessoa(s) que as descrevem, já que, como explica Thompson (2014b, p. 56), a classificação nessa categoria deveria se limitar a esse tipo de construção discursiva de sentimento ${ }^{25}$. Por exemplo, há uma diferença marcante quando Elis diz "No final de tudo, me senti muito mal" e "eles ficaram tristes que a próxima aula seria minha última". Do ponto de vista que assumo, na primeira frase, o 'se sentir muito mal' está no eixo do afeto, pois Elis avalia seu próprio sentimento, fazendo com que a fonte e a direção sejam ela, cujo o efeito é a indução de solidariedade

${ }^{25}$ No original: Affect should be limited to interactant-sourced directed feeling. 
(THOMPSON, 2014b). Na segunda frase, por outro lado, Elis emite uma avaliação sobre os sentimentos de outros, sendo a fonte Elis e a direção os alunos da escola de estágio, o que se caracteriza como julgamento: a licencianda compõe uma 'imagem' de alunos que será interpretada pelos seus interlocutores como de 'alunos carinhosos'. Thompson (2014b, p. 54) fala sobre o que acontece em narrativas para exemplificar melhor essa diferenciação, explicando que, nesse gênero, os sentimentos de outros são tipicamente descritos como forma de ilustrar que tipo de pessoas elas são, dando ao interlocutor informações e direcionando a forma de julgá-las, o que não estaria no escopo do afeto, mas no de julgamento.

Da mesma forma, pode haver dificuldade de categorização em algumas instanciações de atitude que estão "na fronteira" entre julgamento e apreciação. Nessas situações intricadas, a importância de se considerar o cotexto se mostra ainda mais clara: devemos examinar os elementos avaliativos "em termos prosódicos" ao invés de "simplesmente analisar item por item" (MARTIN; ROSE, 2007, p. 39 e 40).

Além disso, é crucial levar em conta que qualquer interpretação é parcial e mostra apenas uma visão sobre determinado discurso já que os contextos culturais e situacionais são diferentes. Como afirmam Martin e Rose (2007, p. 42), a estruturação de afeto, julgamento e apreciação "representam uma construção ocidental de sentimentos" que podem ser entendidos de outra forma em outras culturas. Igualmente, até mesmo a leitura dos dados gerados nesta pesquisa poderia ser feita de diversos modos, visto que os próprios textos "têm significados potenciais mais que suficientes" e sua compreensão depende também da "subjetividade dos leitores" (MARTIN; WHITE, 2005, p. 25). Segundo os autores (ibid.), como analistas do discurso, devemos sempre lembrar ${ }^{27}$ que nossas leituras "são sempre socialmente posicionadas" e nossa obrigação é "declarar nossos 'interesses' da melhor forma possível". Estou ciente de que olharei para as construções identitárias de Elis nos discursos a partir de minhas próprias identidades, permeadas por minhas crenças e emoções. Portanto, reitero que trago nesta tese as minhas leituras, que são algumas interpretações possíveis, e não representam, de forma alguma, as únicas.

As marcas avaliativas dentro do subsistema de atitude parecem predominar nos dados gerados analisados nesta tese e levantam várias questões sobre a

\footnotetext{
${ }^{26}$ No original: The context sensitivity of these borderline items underlines the importance of analysing appraisal in prosodic terms. So, it is important to take co-text into account, rather than analysing simply item by item.

${ }^{27}$ Os autores usam a palavra "remind", acredito que no sentido de deixar registrado e salientar em nossos textos.
} 
construção de identidades crenças e emoções de Elis. Portanto, apesar de ser relevante apontar algumas instanciações de engajamento e gradação, não farei uma discussão mais detalhada desses subsistemas.

O engajamento se baseia na noção de dialogismo de Bakhtin e abarca os mecanismos para "orquestrar vozes no texto" (VIAN JR., 2012, p.121). Assim, mencionarei algumas escolhas de Elis dentro desse subsistema para destacar 0 quanto ela se compromete em relação ao que escreve/diz, expandindo (levantando posições e vozes dialógicas alternativas) ou contraindo (agindo no sentido de limitar, dispersar ou se opor a outras posições ou vozes) dialogicamente seu discurso. Da mesma forma, na análise, chamarei a atenção para algumas instanciações de gradação que a licencianda usou para construir diferentes graus de positividade ou negatividade, ressaltando ou ofuscando avaliações de afeto, julgamento e apreciação, bem como elevando ou diminuindo a intensidade utilizada ou seu investimento na defesa de suas opiniões. Vale lembrar que a gradação permeia tanto o sistema de atitude quanto o de engajamento, modificando a natureza dos significados dentro de suas escalas. A figura 11, a seguir, apresenta as subdivisões das categorias de avaliatividade que serão mencionadas na análise:

Figura 11 - Algumas subdivisões no sistema de avaliatividade

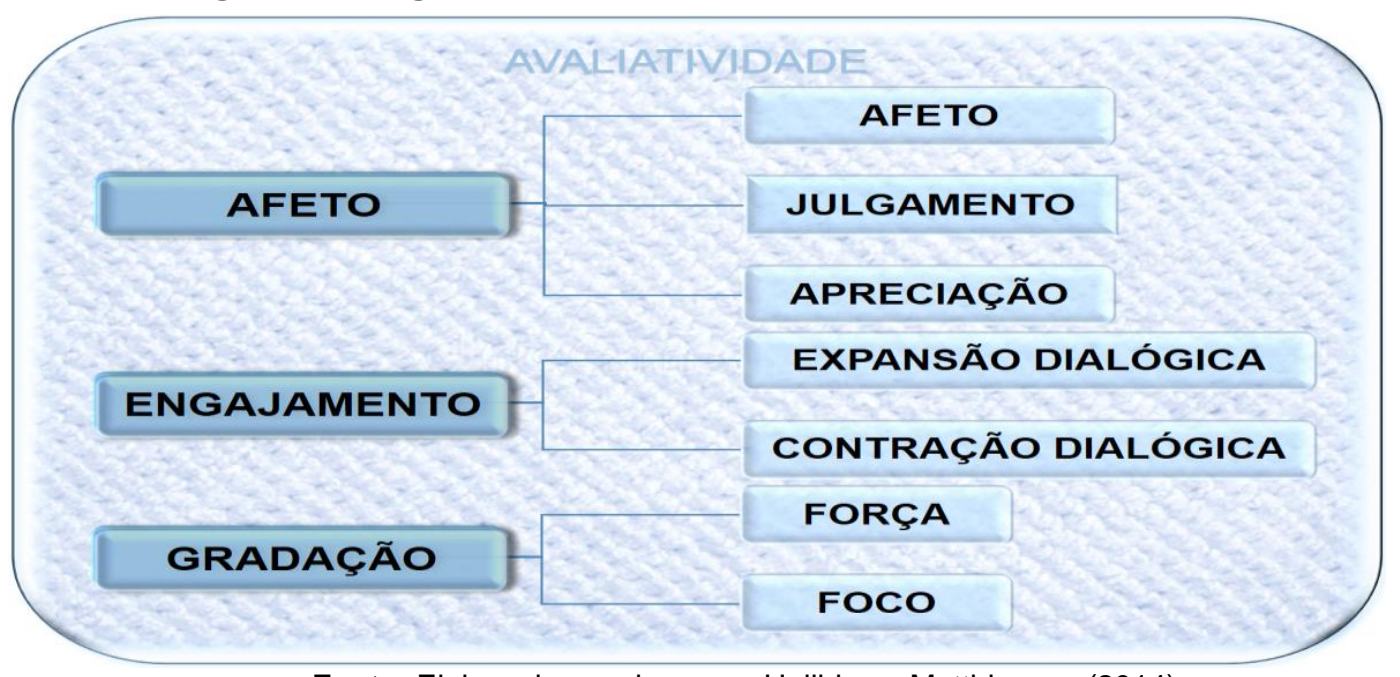

Fonte: Elaborado com base em Halliday e Matthiessen (2014)

Todos os recursos da Linguística Sistêmico-Funcional aqui descritos podem me ajudar a entender como Elis constrói o estágio nos dados e como suas identidades emergem e, por vezes, são reformuladas discursivamente. No próximo capítulo, apresento como a pesquisa foi desenvolvida, a trajetória trilhada 
para a geração e seleção dos dados, o paradigma adotado, o contexto e todo o detalhamento para a condução deste estudo. Passemos, então, à discussão dos procedimentos metodológicos para a produção desta tese, seguindo os pressupostos teóricos explanados. 
Percurso metodológico e contextualização dos dados

\begin{abstract}
O apreço à diversidade diz respeito, também, à exercitar a escuta - não simplesmente ouvir com a razão estreita das coisas da ciência moderna, mas escutar com a razão sensível das coisas da vida.
\end{abstract}

(RESENDE, 2017)

\title{
5.1
}

\section{Paradigma de pesquisa}

O presente estudo está inserido no campo da Linguística Aplicada e se alinha ao paradigma qualitativo interpretativista (ERICKSON, 1986). Segundo Denzin e Lincoln (2006), a pesquisa qualitativa visa investigar "as coisas em seus ambientes naturais, tentando entender ou interpretar os fenômenos em termos dos significados que as pessoas dão aos mesmos" (ibid., p. 2) e se baseia em "um conjunto de práticas materiais e interpretativas" (ibid., p. 7), sendo, portanto, o direcionamento mais adequado para a investigação dos dados gerados nesta investigação. Além disso, adoto outras premissas deste paradigma, que listo a seguir, relacionando-as com minhas escolhas:

1. Parto de "uma atividade situada" (DENZIN; LINCOLN, 2006, p.17), que é o estágio supervisionado dentro de uma comunidade de prática de IFE em uma escola de ensino médio e técnico envolvendo docentes em formação (professores regentes, de Prática de Ensino e estagiários). Nesse contexto, busco entendimentos, ou interpretações, dos significados que os participantes dão aos fenômenos "em seus cenários naturais" (ibid.).

2. Em sintonia com a premissa anterior, considero que o contexto sociocultural é essencial durante todo o processo de investigação aqui proposto, visto que a realidade é socialmente construída (DENZIN; LINCOLN, 2006, p.23), sendo impossível apreendê-la, detalhá-la e/ou explicá-la totalmente. Nego, portanto, o isolamento de um objeto de estudo para sistematização de verdades, igualmente inexistentes. Assim, estou ciente da complexidade da minha empreitada no estudo de alguns dos aspectos da trajetória identitária de uma licencianda no estágio, sobre os quais lanço meu olhar. Logo, não tenho a pretensão de esgotar o assunto e sei que a pesquisa poderia ter outros enfoques, ser feita de muitas outras formas e gerar entendimento distintos. 
3. Parto de uma visão êmica, visando abarcar as perspectivas e significados dos participantes, grupo ao qual pertenço. Declaro minha própria participação no processo, concebo as pessoas e suas ações, experiências, crenças, sentimentos, posicionamentos e visões do mundo como centrais nesta pesquisa e sigo um caminho descritivo, reflexivo e de introspecção dentro do meu contexto.

4. Procedo em minha investigação a partir de diferentes formas de geração de dados na tentativa de enxergar algumas faces do 'prisma' que me propus a pesquisar com vistas a "compreender melhor o assunto" (DENZIN; LINCOLN, 2006, p.17) sem, no entanto, ter a aspiração de abarcar todas as possibilidades de interpretação.

Dentro do paradigma qualitativo interpretativista, entendo esta pesquisa como estudo de caso (STAKE, 2000; LÜDKE; ANDRÉ, 2003), já que procuro estudar em profundidade um fenômeno com ênfase em sua singularidade, mas, ao mesmo tempo, contemplando os contextos situacional e cultural como essenciais, sempre atenta às "suas inter-relações, enquanto um todo orgânico e à sua dinâmica enquanto um processo, uma unidade em ação" (ANDRÉ, 2005, p. 24). Portanto, busco entender um caso contemporâneo (as reconstruções identitárias de uma licencianda durante seu estágio de inglês) com todas as suas peculiaridades, considerando-o como parte inseparável do contexto (que engloba as interações em nossa comunidade de prática de IFE) com vistas a descobrir mais sobre o mesmo e proporcionar ao leitor a ampliação de experiências e a possibilidade de fomentar seu interesse para investigações futuras (ibid., p. 34 e 35).

Alinho-me à Canagarajah (2015) quanto ao posicionamento ético que devemos manter na pesquisa, que está diretamente ligado à responsabilidade para com os participantes durante todo o processo de investigação. Para tanto, tentei exercitar a escuta de uma forma mais ampla, realmente aberta ao compartilhamento de significados para além da pesquisa, como proposto por Resende (2017), citada na epígrafe. Assim, acredito ser imprescindível primar pelo diálogo aberto com os participantes, criando espaços de "interlocução coletiva", conforme sugere Fabrício (2006, p. 62), bem como explicitar nosso contexto, expressar os entendimentos sobre nossas ações e sobre quem estávamos sendo durante o processo de pesquisa.

Expliquei detalhadamente a pesquisa para os participantes antes de convidá-los a fazer parte e, por vezes, durante o processo de escrita da tese, conversei com eles sobre o que eu estava analisando e sua opinião sobre os 
caminhos que eu estava seguindo. Em respeito aos pedidos dos participantes, mantive ou modifiquei seus verdadeiros nomes e omiti qualquer outra informação que não quisessem expor, garantindo a confidencialidade. Além disso, por ter a tese concentrada nas (re)construções identitárias de Elis, enviei minha análise para sua leitura para termos a oportunidade de conversarmos sobre o texto antes de seu fechamento e ela foi convidada para a defesa, assim como todos os outros participantes da pesquisa.

\section{2 \\ 0 contexto da pesquisa}

Nesta seção, busco detalhar o contexto no qual a pesquisa foi desenvolvida. Primeiramente, identifico a escola em que trabalho, onde o estágio em inglês de Elis foi realizado. Além disso, descrevo brevemente como são organizadas as aulas de inglês e trago algumas considerações sobre nossa comunidade de prática de professores de IFE, como também sobre o acolhimento e a coconstrução do estágio em nossas aulas. Finalmente, em outra subseção, apresento os participantes da pesquisa, tendo sido modificados alguns de seus nomes, atendendo a seus pedidos e seguindo critérios éticos.

\subsection{1}

\section{O instituto e as aulas de IFE em nossa comunidade de prática}

O estágio contemplado no presente estudo foi desenvolvido no Instituto Federal de Educação Ciência e Tecnologia do Rio de Janeiro (IFRJ), no campus Rio de Janeiro (mais conhecido como campus Maracanã), ao qual vou me referir também como 'instituto', 'Instituto Federal' e 'escola técnica', além de sua sigla, de forma intercambiável. O site http://ifrj.edu.br/ informa que o IFRJ é uma instituição "de Educação Básica e Superior, pluridisciplinar e multicampi, especializada na oferta de educação profissional e tecnológica em diferentes modalidades, na pesquisa, na inovação e na extensão, gozando de autonomia universitária". Assim, o instituto é constituído nesse momento por quinze campi distribuídos por diversas áreas do estado do Rio de Janeiro, cada um com estrutura e grade de cursos próprias. Torna-se imprescindível destacar que nenhum deles possui o curso de Licenciatura em Letras e nenhum se constitui, a priori, como instituição de estágio supervisionado para a formação de professores 
de Inglês. Cabe à Direção de Ensino (doravante DE) juntamente com o setor pedagógico de cada campus aceitar ou não os estagiários que apresentam seus pedidos para cumprir partes de seus estágios no IFRJ, não havendo nenhuma obrigação institucional para tal.

O campus Rio de Janeiro possui graduação, pós-graduação e ensino médio técnico com uma variada gama de cursos, como mostra o quadro 3, a seguir.

Quadro 3 - Cursos oferecidos pelo IFRJ campus Rio de Janeiro

\begin{tabular}{|l|l|}
\hline ENSINO MÉDIO TÉCNICO & \multicolumn{1}{|c|}{ GRADUAÇÃO E PÓS-GRADUAÇÃO } \\
\hline Alimentos & Bacharelado em Ciências Biológicas \\
Biotecnologia & $\begin{array}{l}\text { Curso Superior de Tecnologia em Gestão Ambiental } \\
\text { Farmácia }\end{array}$ \\
Meio Ambiente & $\begin{array}{l}\text { Mestrado e Doutorado em Bioquímica e Biologia Molecular } \\
\text { Química }\end{array}$ \\
$\begin{array}{l}\text { Manutenção e Suporte em } \\
\text { Informática (Educação de de } \\
\text { Jovens e Adultos - EJA) }\end{array}$ & $\begin{array}{l}\text { Especialização em Ensino de Ciências } \\
\text { Especialização em Gestão da Segurança dos Alimentos e } \\
\text { Qualidade Nutricional }\end{array}$ \\
\hline
\end{tabular}

Fonte: Quadro de minha autoria elaborado a partir do site do IFRJ (https://ifrj.edu.br/)

Além dos cursos listados no quadro 3, o IFRJ oferece o 'Pós Médio de Química' (PMQ), que é um curso técnico em Química que pode ser feito concomitantemente ou subsequentemente ao ensino médio. Todos os cursos de ensino médio técnico têm Inglês para Fins Específicos em três ou quatro semestres consecutivos e as turmas de PMQ têm apenas dois semestres, sendo a disciplina obrigatória em ambos os casos. Na graduação (em Ciências Biológicas, Gestão Ambiental e Processos Químicos), o IFE é uma disciplina eletiva que pode ser feita em um semestre e as turmas são formadas por alunos de diferentes períodos dentro de seu curso. A disciplina Inglês para Fins Específicos não está presente nos cursos de pós-graduação do campus. Todas essas opções são abertas aos estagiários e eles são convidados a acompanhar qualquer turma de ensino médio técnico ou de graduação, que estão sob a responsabilidade da equipe de IFE. Como Elis só acompanhou as turmas de ensino médio, vou me ater à descrição de nossas aulas apenas nesse seguimento.

O ensino médio técnico no IFRJ é dividido em semestres, somando um total mínimo de quatro anos com aulas de segunda a sábado. A maior parte da carga horária dos cursos de química, biotecnologia e farmácia é preenchida no turno da manhã, enquanto a dos cursos de meio-ambiente e alimentos se dá à tarde e dos cursos de manutenção e suporte em informática e de PMQ fica à noite. Entretanto, em alguns dias é necessário que os alunos fiquem até mais tarde ou cheguem 
mais cedo para algumas disciplinas que são no contraturno (CT). Elis cita a questão do CT ecoando nossa apreensão quanto às turmas que ficam nesses horários. Tal apreensão se justifica porque é comum o esvaziamento dessas turmas, o que prejudica o desenvolvimento de nossas aulas.

Alguns pontos que chamam muito a atenção dos estagiários quanto ao IFRJ em comparação a outras escolas são a dinâmica da circulação dos alunos nos espaços do instituto e a exigência imposta pelos programas: os alunos se deslocam pelo campus para ter aulas das diferentes disciplinas, fazem estágio nos últimos períodos, estão constantemente envolvidos em pesquisa e apresentam trabalhos em eventos acadêmicos, incluindo a Semana da Química, que é um evento anual dos alunos do instituto. Essas características são frequentemente destacadas pelos estagiários em seus textos (memoriais e diários) como pontos que eles (estagiários) têm em comum com os alunos do IFRJ, o que parece criar empatia, como poderá ser observado nos dados de Elis (cf. capítulo 6). Em contrapartida, os alunos são normalmente muito atenciosos, respeitosos e acolhedores com os estagiários. Acredito que esse compartilhamento de experiências comuns, além do fato de a faixa etária entre alunos e estagiários ser geralmente muito próxima, facilita a comunicação entre eles. Além disso, sinto que a relação de parceria, de ajuda mútua, que eles desenvolvem se assemelha e talvez também ecoe o tipo de relacionamento que coconstruímos em nossas aulas de IFE.

As aulas de inglês, que seguem a abordagem de IFE, começam a partir do terceiro período na maior parte dos cursos de Ensino Médio e os semestres da disciplina são identificados como inglês 1 (com dois tempos semanais), inglês 2 (com quatro tempos) e inglês 3 (com dois tempos). A exceção são as turmas de biotecnologia, que têm o conteúdo do inglês 2 dividido em dois semestres de dois tempos e têm inglês 4 (que completam os últimos dois tempos para ficar com a grade da disciplina igual à das outras turmas). Nossa comunidade de prática da equipe de professores de IFE do campus Rio de Janeiro é formada por seis professores e todos podem pegar qualquer turma, dependendo do horário que decidimos semestralmente em uma das reuniões da equipe.

Usamos as primeiras semanas com as turmas de inglês 1 para iniciar a análise de necessidades que, naquele momento, engloba principalmente o debate sobre a vivência daqueles alunos com a língua inglesa, suas preferências quanto à forma de condução das aulas, como eles acreditam que aprendem e o que eles gostariam de aprender, além de um teste de nivelamento escrito. Lembro que essa análise é um processo constante e, por isso, consideramos que esses são 
somente os primeiros passos em nossa caminhada para conhecer a turma (conforme explicado na seção 2.1.1). A partir dos dados que são gerados nesses primeiros encontros, também fazemos a divisão da turma em dois grupos. Isso acontece porque não possuímos o espaço para acomodar uma turma inteira em nossas salas, além de acreditarmos que podemos analisar e construir com os alunos o nosso curso de IFE de forma mais proveitosa quando eles estão em um número menor. Temos duas salas de inglês que comportam, no máximo, cerca de vinte alunos e as turmas muitas vezes são formadas por mais de trinta no inglês 1. Entretanto, não dividimos simplesmente a turma ao meio ou utilizamos critérios que os desconsiderem como pessoas (como, por exemplo, dividi-los pela ordem alfabética na lista de presença), mas usamos a análise de necessidades para guiar esse procedimento. Primamos por contemplar a visão deles durante o processo ${ }^{28}$ e esclarecer junto aos alunos como e porque a divisão é feita.

Cabe salientar que nós (a equipe de professores) acreditamos que todos os alunos, com qualquer nível de inglês, podem participar das aulas de IFE e que o mesmo conteúdo é trabalhado com as duas partes da turma. Assim que se torna possível acomodá-los no espaço que temos, a turma é unida novamente, o que geralmente acontece no inglês 2 . Entretanto, na maior parte das vezes, temos a formação de um grupo com o conhecimento de inglês mais básico e o outro menos básico no inglês 1. Essa divisão, além de resolver a questão do espaço da sala, também nos permite atender melhor às necessidades de cada grupo formado. Em ambos os grupos, as aulas não se restringem à leitura de textos da língua alvo, mas abarcam todas as quatro habilidades (compreensão e produção oral e escrita), o que também exige muito dos professores na elaboração de materiais didáticos de acordo com as peculiaridades de cada parte da turma. $O$ fato de termos grupos não tão grandes também nos ajuda nessa empreitada posto que nos permite, entre outros fatores, promover a participação de um maior número de alunos no pouco tempo que a nossa disciplina dispõe na grade escolar.

Em nossa rotina, é necessária a constante pesquisa não só junto aos alunos (atuais e egressos), mas também aos professores de outras disciplinas, e até ao mercado de trabalho para repensar as ementas e materiais periodicamente. Tal investigação pode (e, em meu entendimento, deve) envolver os próprios alunos como parceiros pesquisadores na análise de necessidades como foi feito, por exemplo, nos trabalhos de Monteiro et al (2015) e Souza et al. (2017), que foram

\footnotetext{
28 Um aluno pode, por exemplo, 'sentir' que precisa participar do grupo menos básico, talvez por uma questão de orgulho próprio por já ter alguma experiência com inglês. Em um caso como esse, mesmo tendo sido indicado para o mais básico, ele pode conversar com seu professor e, juntos, eles analisam a possibilidade de mudança de grupo.
} 
fruto de pesquisas de alunos conosco e foram apresentadas em eventos acadêmicos. No entanto, tais pesquisas não implicam em transformações diretas nas ementas, já que tais modificações devem ser sempre discutidas institucionalmente, não só dentro do próprio campus, mas também em conjunto com as equipes de outros campi do IFRJ que possuem o mesmo curso.

Os materiais, por outro lado, são constantemente revistos na busca de atender as necessidades em nosso contexto (HUTCHINSON; WATERS, 1987; DUDLEY-EVANS; ST JOHN, 1998), ficam disponíveis para toda a equipe e são abertos a modificações, que também são compartilhadas. Nós nos empenhamos na produção de materiais que englobem os gêneros discursivos, os assuntos da área de interesse e os aspectos lexicogramaticais pertinentes e relevantes para os nossos alunos. Muitos dos nossos materiais são elaborados a partir de sugestões dos alunos e alguns são feitos em conjunto com eles. Também consideramos de extrema importância que as atividades sugeridas abordem a multimodalidade e promovam a reflexão crítica sobre os textos e buscamos elaborar materiais que permitam "um grau de negociação que valorize os múltiplos olhares trazidos pelos alunos para a sala de aula" (SOUZA, 2016, p. 91).

Portanto, a comunidade de prática de professores de IFE do instituto, da qual faço parte, é formada por professores engajados na análise de necessidades para as aulas de IFE e no compartilhamento de experiências. A maior parte de nós também faz outras pesquisas sobre suas salas de aula além de produzirmos nossos próprios materiais didáticos, que são renovados de forma constante, compartilhados e adaptados pela equipe. Como explicado no capítulo 2 , todas essas tarefas são algumas das várias responsabilidades do professor de IFE e fazem parte do nosso dia a dia. Contudo, a partir dos dados gerados para esta pesquisa, posso dizer que nossa rotina, principalmente no que tange o envolvimento em pesquisa (das necessidades e projetos), a autonomia e a elaboração constante de materiais, surpreendeu, gerou questionamentos e ansiedade em Elis e seus colegas estagiários, conforme será discutido na análise.

\section{2 .2}

\section{O estágio em nossa comunidade de prática}

Há alguns anos nossa equipe de IFE assumiu mais um compromisso, que concerne a formação de professores. Tal compromisso foi uma decisão nossa de receber licenciandos que entram com o pedido para estagiar no IFRJ dentro de 
nossas possibilidades. Consideramos, por exemplo, a compatibilidade entre a disponibilidade dos licenciandos e a grade semanal de aulas de inglês, bem como o espaço nas salas para acomodar estagiários. É essencial explicar que o estágio não é considerado uma de nossas atribuições e não recebemos nenhuma forma de remuneração para desenvolvê-lo, como bolsas de auxílio, por exemplo.

Estagiários de diferentes instituições, cursando licenciaturas diversas, podem entrar com o pedido no IFRJ para fazer seu estágio junto à Direção de Ensino (DE) e à Coordenação Técnico Pedagógica do instituto (a qual vou me referir como CoTP), que são os órgãos responsáveis pela autorização e documentação para o estágio. Os estagiários devem, por exemplo, entregar a Carta de Apresentação e o documento do seguro, que são da universidade, e preencher uma ficha com suas informações, bem como ler assinar o Termo de Compromisso, que é um documento elaborado pelo instituto que lista os direitos e deveres dos licenciandos no IFRJ. Esse último documento deve ser assinado pelos estagiários, pelos coordenadores de área ou pelos professores regentes e pelo diretor de ensino. Após conseguirem a autorização da DE, os estagiários ainda devem averiguar com os coordenadores dos cursos se há horários disponíveis e professores que os aceitem em suas salas de aula antes de ir à CoTP. Portanto, o estágio também depende do aval do professor regente, tanto que muitos professores de outras disciplinas se recusam a receber estagiários no IFRJ e o estágio não acontece. Lembro que, mesmo que os licenciandos tenham meios de entrar em contato direto com o professor, é preciso primeiramente obter a autorização da DE e eles não podem iniciar as atividades no IFRJ sem apresentar toda a documentação exigida pela CoTP. Mesmo em um caso como o da nossa equipe de IFE, por exemplo, em que a DE já está ciente sobre nossa disposição para receber estagiários, esse órgão deve ser consultado primeiro.

Elis faz parte do grupo de estagiários que recebemos em 2016 da Universidade Federal do Rio de Janeiro, doravante UFRJ, e eles dispõem de um colégio de aplicação para realizar seu estágio, que fica na Lagoa. Entretanto, os estagiários têm como opção fazer o estágio em outras escolas de ensino médio à escolha da professora de Prática de Ensino. Para tanto, é também necessário que tais escolas autorizem e que elas estejam de acordo com as regras do seguro da universidade. As aulas de inglês do instituto se tornaram uma dessas opções para as professoras de Prática de Ensino do curso de Letras Inglês/Português da UFRJ em uma parceria que foi se delineando aos poucos.

Em 2013, nossa equipe de IFE recebeu o primeiro grupo com três estagiários, que vieram diretamente ao instituto com a permissão de sua 
professora da UFRJ. Naquela ocasião, nós só nos encontramos com a professora da universidade no dia da regência de seus licenciandos e somente em 2014 houve um contato efetivo com uma das professoras de Prática de Ensino para discutir como seria essa parceria.

Durante os primeiros anos de estágio, tivemos muitas situações angustiantes e não sabíamos muito bem como proceder quanto aos licenciandos. Por exemplo, alguns estagiários se ausentavam durante semanas e voltavam depois de já termos considerado abandono, não faziam tarefas que pedíamos para o planejamento e participação nas aulas e se comportavam de formas que até os alunos reclamavam (chegando tarde demais, interrompendo a aula por estar conversando alto sobre outros assuntos com outros colegas estagiários, entre outros). Além disso, havia aquela sensação de que os estagiários estavam ali apenas para cumprir horas, criticar o que fazíamos em seus relatórios para a universidade e fazer uma avaliação de aula no final. Muitos professores rejeitam estagiários em suas salas porque sentem que perdem sua liberdade e que se sentem analisados o tempo todo e, para a minha equipe de IFE, isso também esteve presente. Por muitas vezes, discutimos em nosso grupo nossas dúvidas e insatisfações por querer que os estagiários se integrassem mais, mas ainda parecia haver um distanciamento muito grande entre nós e eles.

Essas crenças e emoções pareciam ser também partilhadas por professores de outras disciplinas e as reclamações deles se acumulavam na DE e na CoTP. Por isso, no ano de 2014, foi formado um grupo de trabalho com representantes das diferentes equipes que se reuniu periodicamente para discutir sobre o estágio no IFRJ e elaborar um documento, explicando as responsabilidades da escola, dos professores formadores e dos estagiários. Ele foi chamado de Termo de Compromisso e tinha como objetivos principais esclarecer o que entendíamos como nossos direitos e deveres (dos professores, da escola e dos estagiários) e fazer com que isso chegasse ao conhecimento de todos. Esse documento seria enviado às professoras de Prática de Ensino e discutido com seus alunos antes de eles se candidatarem a estagiar no IFRJ. O Termo de Compromisso se tornou um dos documentos obrigatórios para ser lido, assinado e entregue na CoTP antes de iniciar o estágio no instituto.

No final de 2015, nós, professores de IFE, nos reunimos para planejar o semestre que se iniciaria porque sentimos a necessidade de refletir sobre a experiência do estágio e nos preparar para receber um novo grupo. Dois dos tópicos discutidos foram a nossa responsabilidade também como professores formadores e não apenas "professores observados" (conforme discutido por 
BUENO, 2007, p. 213) e a necessidade de promover uma maior participação dos estagiários no planejamento e desenvolvimento das aulas. Por isso, nessa reunião, tomamos algumas decisões sobre como proceder, que tentamos implementar desde então:

1. Promoção de um encontro com todo grupo novo de licenciandos que chegam ao instituto antes de iniciar o estágio de inglês para uma primeira conversa com um(a) representante de nossa comunidade de prática. Quando Elis deu início ao processo de estágio no instituto, eu era a responsável por acolher os licenciandos por ser a coordenadora de Línguas Estrangeiras naquele semestre;

2. Apresentação dos licenciandos aos alunos como professores em formação e acolhidos por nossa equipe;

3. Preparação de orientações, indicação e discussão de textos sobre a teoria que embasa o trabalho sobre Línguas para Fins Específicos e realização de oficinas de elaboração de materiais didáticos;

4. Criação de espaços para o compartilhamento de experiências com os estagiários (como as conversas que fazem parte dos dados gerados para esta pesquisa) e de oportunidades para participarem da análise de necessidades, do desenvolvimento de materiais e do planejamento e condução de partes das aulas;

5. Estabelecimento de alguma comunicação com as professoras de Prática de Ensino, o que conseguimos fazer normalmente por e-mail e WhatsApp. Os encontros presenciais geralmente só acontecem no dia da regência, mas a professora de Prática de Ensino de Elis esteve na escola outras vezes, incluindo o dia da reunião inicial antes do estágio;

6. Organização do estágio: Cada estagiário ficaria com um professororientador, mas com a possibilidade de acompanhamento de outros professores durante o período de estágio. Cada professor regente de IFE ficou responsável por dois, três ou quatro estagiários no semestre em que esta pesquisa foi desenvolvida, de acordo com a nossas disponibilidades e as deles. No caso de Elis, por exemplo, sua professora-orientadora era Maria, mas ela participava das minhas aulas às quintas-feiras. Ela tinha maior convivência no estágio com os estagiários Hugo, Lara, Fábio, Enzo, Léa e Ana.

Acredito que as reuniões periódicas que nós da equipe de IFE fazemos para discutir nossas histórias, compartilhar ideias e tirar dúvidas sobre o nosso dia-a- 
dia na escola, incluindo o estágio, nos ajudou a superar aos poucos essa negatividade. Quando recebemos o grupo de estagiários do qual Elis faz parte, já tínhamos ganhado um pouco mais de experiência e muito do receio de acolher novas pessoas em nossas salas já tinha passado. Nesse momento, nós já tínhamos percebido o quão enriquecedor pode ser essa colaboração pois, diferente do que pensávamos antes, aprendíamos muito com os licenciandos também e passamos a nos concentrar no acolhimento desses professores em formação inicial.

\subsection{3 \\ Os participantes da pesquisa}

Nesta subseção, discorro brevemente sobre os participantes da pesquisa, dentre os quais está Elis, cujas (re)construções identitárias serão analisadas. Apesar de as contribuições dos professores (eu e Maria, que somos as regentes,

e Flávia, que é a de Prática de Ensino) e dos outros estagiários não serem o foco da análise, é essencial que eu contemple algumas informações sobre essas pessoas e sua relação com Elis durante o estágio, posto que: a) a análise dos dados está pautada no conjunto de identidades, emoções e crenças que me constituem e é necessário que eu declare de onde eu falo; b) nós somos mencionados e avaliados por Elis nos textos aqui analisados e interagimos com ela durante a geração dos dados orais e, portanto, essas informações fazem parte do contexto, que influencia e é influenciado pela linguagem usada pela estagiária; e c) esta pesquisa consiste em um estudo de caso e exige o detalhamento do contexto estudado. Assim, ainda que de forma bem sintetizada, trago algumas informações não só sobre Elis, mas também sobre as professoras e os licenciandos que participaram com ela desta pesquisa. Por razões éticas, alguns dos nomes dos participantes foram substituídos e outros dados omitidos a pedido deles.

\subsubsection{1}

\section{As professoras de Elis}

Carla - Eu fui uma das professoras que Elis acompanhou durante o estágio e sou a responsável por esta pesquisa. Sou professora de Inglês para Fins Específicos, integrante do quadro permanente e dedicação exclusiva do IFRJ desde 2012, 
mas, nos meus vinte anos na carreira docente, já tive diversas experiências em diferentes instituições e segmentos (Educação Infantil, Ensino Fundamental, Ensino Médio e Educação Superior) e sempre fui apaixonada pelo que faço. Trabalhei, por exemplo, como professora na alfabetização de crianças em uma escola privada por um ano (após a formação em nível médio para a docência na Educação Básica em 1998, que era chamada como curso Normal). Após me formar no Bacharelado e Licenciatura em Letras Português/Inglês na UFRJ em 2004, trabalhei com todos os anos do segundo segmento do Ensino Fundamental e do Ensino Médio da Secretaria de Estado de Educação do Rio de Janeiro (até 2011). Fui professora de inglês de cursos livres por quinze anos e, em 2011, assumi o cargo de professora substituta nas disciplinas de Prática de Ensino e Didática Especial na UFRJ. Fiz o curso de Especialização em Linguística Aplicada (Inglês como Língua Estrangeira) na UERJ em 2010, completei o Mestrado em Linguística em 2012, também na UERJ e sou doutoranda de Estudos da Linguagem da Pontifícia Universidade Católica do Rio de Janeiro desde 2015. Hoje, eu sou profissional de IFE e me dedico apenas à escola locus deste estudo, mas, como os estagiários que acolhemos no instituto, tive muita dificuldade no início de minha carreira com IFE e creio que o apoio dos meus colegas e alunos, bem como nossos compartilhamentos constantes (de conhecimentos, experiências e afeto) foram e são essenciais em minha formação docente.

Maria - Maria foi a professora que ficou responsável pela orientação de Elis no IFRJ. Ela é profissional de IFE no instituto desde 2008 e pesquisadora institucional entre outras de suas atribuições como, por exemplo, integrante de grupos de trabalho no campus. Ela é um dos membros mais centrais de nossa comunidade de prática e é muito querida pelos estagiários. Atualmente, Maria cursa o Doutorado em Linguística e sua pesquisa também versa sobre a formação de professores. Ela concluiu o Mestrado em Linguística Aplicada, é graduada em Letras Português/Inglês com aperfeiçoamento em Métodos e Técnicas no Ensino de Inglês como Língua Estrangeira e é especialista em Docência Superior com curso de extensão universitária em Capacitação de Professores para EAD.

Flávia - Flávia é Mestre pelo Programa Interdisciplinar de Linguística Aplicada da UFRJ e professora de inglês do ensino básico da rede pública estadual desde 2014. Ela fez parte de um dos primeiros grupos de estagiários que acolhemos no instituto em 2013, quando ela cursava a licenciatura em Letras (Português/Inglês) na UFRJ. Ela era professora substituta de Prática de Ensino da UFRJ quando esta 
pesquisa foi desenvolvida. Sempre muito atenta a seus alunos no estágio, mantinha contato com os professores regentes por e-mail e telefone, como também foi à escola algumas vezes para conversar conosco sobre o desenvolvimento do estágio e discutir algumas questões específicas de alguns licenciandos.

Podemos perceber que nós três somos professoras em formação que temos uma história juntas: compartilhamos vivências no estágio, primeiramente com Elza e eu como professoras regentes de Flávia, que, anos depois de terminar a licenciatura, voltou à nossa comunidade de prática como professora da graduação trazendo seus estagiários para negociar conhecimentos conosco. O fato de as pessoas estarem todas integradas não é visto nesta pesquisa como algo negativo, pois não busco generalizações, verdades ou neutralidade, que, a meu ver nem mesmo existe.

Portanto, reitero que esta pesquisa se baseia nos entendimentos de nossas experiências a partir do contexto em que elas acontecem, com toda a sua complexidade. Seguindo essa premissa, o vínculo entre as professoras participantes da presente pesquisa, que poderia ser considerado uma complicação por um ponto de vista positivista, é aqui compreendido como algo que pode ter sido benéfico. Flávia conviveu conosco como membro de nossa comunidade de prática de IFE e provavelmente teve suas próprias experiências de (re)construções de identidades-crenças-emoções durante o estágio, tornandose um par mais competente para auxiliar seus licenciandos naquele contexto de diferentes formas. Além disso, os laços criados entre as professoras durante os anos também facilitaram nossos contatos para apoiar os estagiários. De qualquer forma, acredito que a proximidade e a colaboração entre professores formadores devem ser buscadas para que haja mais oportunidades de aprendizado mútuo e a construção conjunta do estágio. Em nosso caso, isso apenas começou a ser desenvolvido antes.

\subsubsection{2}

\section{Os licenciandos que são contemplados nos dados}

Os estagiários que participaram da pesquisa eram licenciandos de Letras com dupla habilitação (Português e Inglês) na UFRJ e deveriam cumprir 120 horas em Língua Inglesa no instituto. Nesta pesquisa, os licenciandos citados nos dados 
são Enzo, Ana, Hugo, Elis, Fábio, Lara e Léa. Desse grupo, somente Elis, cujas identidades são o foco desta pesquisa, será descrita separadamente.

Elis era a única de seu grupo sem nenhuma prática como docente e os outros tinham experiência de poucos meses como professores em cursos livres de Inglês, mas, mesmo para esses últimos, a realidade da profissão no ensino médio em escola pública era novidade. Além disso, o uso de IFE e o fato de IFRJ ser uma escola de ensino médio e técnico (com cursos na área científica com foco em Química) foram elementos que causaram estranhamento e temor nas primeiras aulas, como podemos observar nos dados gerados para este estudo.

De forma geral, os docentes da área de línguas parecem ter muita dificuldade para se adaptar a esse ambiente, pois não estão preparados para lidar com as demandas atualmente emergentes do mercado de trabalho e as especificidades exigidas nos cursos de IFE, principalmente com os gêneros e o vocabulário específicos das áreas em que os alunos vão atuar (RAMOS; FREIRE, 2009). A preparação para as aulas de inglês no instituto também envolve a constante renovação e construção de materiais didáticos, pois não adotamos livro, o que, segundo os estagiários participantes desta pesquisa, também dificultou sua adaptação (por estarem acostumados a se "guiar por métodos dos cursinhos e por livros didáticos") mas, ao mesmo tempo, os deixou "empolgados" (por causa da "autonomia intelectual" e o fato de "não depender").

Nos últimos dias de estágio, Elis gravou um vídeo, no qual se apresenta da seguinte forma: "Meu nome é Elis e eu sou aluna da faculdade de Letras e faço Português/Inglês e fiz o meu estágio supervisionado na escola técnica". Quando fez o estágio conosco, ela tinha idade muito próxima à dos alunos do instituto que ela acompanhou e pareceu ter se identificado com muitos deles, principalmente com aqueles que mostravam maior insegurança e moravam longe como ela. Além de pedir para não revelar seu nome, a idade certa e outras especificidades, Elis se mostrava muito reticente no início da pesquisa e quase não falava. Entretanto, sua postura mudou completamente com o passar dos dias e, já na terceira semana, ela começou a tomar o turno várias vezes para expor suas opiniões e se voluntariar para conduzir atividades. A partir das minhas anotações em diário, trago aqui alguns comentários sobre minhas impressões acerca da licencianda durante o período de pré-serviço.

O primeiro dia de Elis no estágio foi em uma turma de Biotecnologia e, depois de apresentá-la e a dois de seus dois colegas como "os três outros professores" à turma e dizer que eles estavam ali para negociar conhecimentos conosco (comigo e com os alunos), os licenciandos se dirigiram às últimas 
carteiras da sala e apenas observaram e fizeram anotações durante a maior parte da aula. Como em todos os outros primeiros dias de estagiários em nossas turmas, pelo que pude perceber até hoje, as expressões dos licenciandos mostravam espanto e apreensão.

$\mathrm{Na}$ última atividade, eu os incluí nos grupos de alunos para ajudá-los a construir a argumentação para um debate. Depois da aula, conversamos sobre nossas impressões acerca do que ocorreu e eu reforcei a necessidade de eles se engajarem nas atividades com os alunos, sentarem em lugares diferentes, ajudar quando se sentissem confortáveis e realmente se incluírem, dando opiniões, perguntando, planejando junto e, por vezes, assumindo o papel de organizadores das tarefas durante as aulas. No início, Elis era a mais quieta deles e eu tinha que fazer perguntas diretamente a ela para obter alguma resposta. Nessa primeira conversa, ela disse que ficou assustada e insegura por achar vários aspectos extremamente diferentes do que estava acostumada, dentre eles, a dinâmica da aula, os alunos, os materiais utilizados, a relação professor-aluno e, principalmente, o conteúdo específico abordado em IFE. Elis aos poucos foi se desinibindo e, logo após a primeira semana, começou a se voluntariar para ajudar a mim e aos alunos.

Apesar de, por vezes, ficar visivelmente ansiosa quando tinha alguma tarefa docente sob sua responsabilidade, ela sempre contribuía no planejamento e implementação das aulas. Na verdade, os estagiários que acompanhavam minhas aulas às quintas-feiras de manhã ${ }^{29}$ eram muito proativos, interessados, entusiasmados e gentis. Eles conquistaram o respeito dos alunos e pareciam cada vez mais incorporados à nossa comunidade de prática. Elis participou ativamente de tudo o que pôde e parece ter efetivamente aproveitado muito o estágio, já que, dentre outras atuações, ela: produziu materiais didáticos em conjunto conosco (eu, Maria e outros estagiários); monitorou atividades dos alunos e tirou dúvidas deles; assumiu uma postura adequada (de assiduidade, pontualidade e respeito às regras da escola, por exemplo); completou o estágio dentro de um semestre e cumpriu todas as exigências para apresentar sua regência; interagiu com diferentes professores; participou de reuniões, minicursos e oficinas dentro e fora do instituto; e fez pesquisa sobre/no estágio. Na próxima subseção, explicito como aconteceram os primeiros contatos com os estagiários e os procedimentos antes de iniciar a pesquisa.

${ }^{29}$ Normalmente, dois a quatro estagiários estavam nesse horário e Elis sempre era um deles. 


\section{3 \\ O convite para participar da pesquisa}

Quando procedi ao convite dos participantes para esta pesquisa, os licenciandos já tinham sido aceitos para fazer o estágio no IFRJ pela Direção de Ensino e, normalmente, como já explicado, após obter essa autorização, eles devem se apresentar à CoTP para ler, preencher, assinar e entregar alguns documentos. Em nossa equipe de IFE, preparamos uma acolhida para os estagiários antes de seu primeiro encontro com as turmas e eles às vezes aproveitam essa ida à nossa escola para ir ao setor pedagógico e fazer todo o procedimento com a documentação. Enfatizo que essas reuniões de acolhida ocorrem somente após a autorização da DE para fazer o estágio no IFRJ e esses encontros não são obrigatórios, não sendo nem mesmo um procedimento seguido pelas coordenações de outras disciplinas. A respeito da não obrigatoriedade, posso citar o exemplo de uma licencianda ${ }^{30}$ da turma de Elis que não pôde participar dos encontros, mas estagiou no instituto juntamente com os colegas que estiveram presentes. Na verdade, as reuniões são uma iniciativa da equipe de IFE que nasceu para atender uma necessidade que percebemos a partir de nossas experiências nos semestres anteriores.

Após a anuência da DE para a realização do estágio de Português e Inglês em nossa escola naquele semestre, pude enviar os horários da equipe de Inglês com a indicação do número de estagiários que seria possível acomodar em cada turma para as professoras de Prática de Ensino. Em uma segunda mensagem, os estagiários foram convidados a vir ao instituto para conversar conosco antes do início do estágio. Para que todos os estagiários tivessem a possibilidade de comparecer, a equipe disponibilizou duas opções para a reunião, compreendendo dias e turnos diferentes: uma terça-feira de manhã e uma quinta-feira à tarde. Nesses dois dias, eu fiquei responsável por receber os licenciandos, mas contamos com a participação de outros professores da equipe de IFE, que passaram alguns minutos conosco nos intervalos de suas aulas, se apresentaram e também compartilharam informações nos encontros.

Nessas reuniões de acolhida, conversei com os estagiários sobre o instituto e o estágio, li com eles e tirei dúvidas sobre o Termo de Compromisso, expliquei

\footnotetext{
${ }^{30}$ Essa licencianda conversou comigo e outros dois professores da nossa equipe de IFE alguns dias depois da reunião, em um de nossos intervalos entre aulas, já depois de ter feito todo o processo de documentação com a CoTP. Nessa conversa, dentre outras coisas, ela escolheu os dias em que ela podia estagiar, conheceu sua professora regente e falamos sobre o estágio, mas não mencionei a minha investigação naquele momento. Ela foi convidada a participar da minha pesquisa, leu a documentação e aceitou o convite quando já tinha começado a acompanhar as turmas.
} 
os horários das aulas de inglês, passei os contatos de todos os professores de IFE e tentei responder as perguntas que eles tinham. As dúvidas deles giraram em torno do preenchimento da documentação e dos ajustes entre sua disponibilidade e os horários no estágio.

É importante mencionar que o horário pareceu ser grande motivo de ansiedade para todos os licenciandos presentes ${ }^{31}$ e teve que ser ajustado várias vezes. Os estagiários só podiam cumprir 20 horas de estágio semanais segundo determinação das professoras de Prática de Ensino e queriam tentar incluir tanto português quanto inglês nessas horas. Essas restrições geram muitas dificuldades, já que, às vezes, as horas disponíveis de estágio não coincidem com o tempo que eles têm para fazê-lo. Ao mesmo tempo, eles estavam com receio de não conseguirem compatibilidade com a grade de horários no IFRJ. Em Inglês, minha equipe conseguiu absorver a todos, mas o mesmo não aconteceu em Português e alguns licenciandos teriam que fazer parte do estágio em outra escola. Segundo eles, o estágio estava assegurado no Colégio de Aplicação da UFRJ, mas eles consideravam a instituição como sua última opção pela questão da distância e sua dificuldade tanto para chegar lá cedo quanto para se deslocar de volta para a faculdade ou suas casas ou, em alguns casos, para seus empregos.

Em um segundo momento, quando os licenciandos já tinham escolhido horários e professores regentes responsáveis de IFE e preparado a documentação para setor pedagógico, com muitos já tendo entregue tudo como pedido, expliquei minha pesquisa de doutorado e fiz o convite para que eles participassem. Salientei que a participação em meu estudo não estava vinculada ao processo de estágio, fiz a leitura do Termo de Consentimento Livre e Esclarecido (TCLE) ${ }^{32}$ com eles e respondi a algumas perguntas que eles fizeram sobre a pesquisa. Os questionamentos estavam particularmente centrados no processo de pesquisa (como, por exemplo, a documentação necessária), porque eles também deveriam desenvolver uma investigação sobre um tema que despertasse o interesse deles durante o estágio, o que se constituía em um dos trabalhos pedidos pelas professoras de Prática de Ensino. Dois estagiários não quiseram participar da pesquisa, mas os outros aceitaram o convite ${ }^{33}$ e assinaram

\footnotetext{
${ }^{31}$ Observação registrada em meu diário nos dias de reunião.

32 O modelo do TCLE encontra-se em anexo e está de acordo com a Resolução n 466, de 12 de dezembro de 2012, considerando fundamentalmente o respeito aos participantes das pesquisas científicas envolvendo seres humanos e o engajamento ético, que é inerente ao desenvolvimento científico e tecnológico.

${ }^{33} \mathrm{Um}$ dos estagiários participantes da pesquisa desistiu do estágio no |IFRJ pois não conseguiu vaga em Português.
} 
duas vias do TCLE, ficando uma com eles.

Por fim, os estagiários responderam quatro perguntas iniciais elaboradas por mim com o objetivo de saber um pouco sobre o que eles pensavam, esperavam e conheciam sobre o estágio e o IFE. Eles escreveram suas respostas que, com a permissão dos participantes, foram recolhidas e posteriormente analisadas por mim. Eu tirei cópia das folhas com as respostas e as devolvi a seus autores para que, em uma oportunidade futura, pudéssemos conversar sobre elas, como aconteceu em uma das reuniões cujos alguns trechos foram transcritos e analisados nesta tese.

Os professores regentes e de Prática de Ensino foram convidados para participar da pesquisa em uma de nossas reuniões para conversar sobre o estágio no final de 2015 e também assinaram duas vias do TCLE, após eu ter explicado detalhadamente a pesquisa e eles terem aceito o convite. Todos os estagiários e professores que aceitaram participar foram muito receptivos quanto à pesquisa. Mesmo sem nenhuma obrigatoriedade, os estagiários voltavam rapidamente depois do intervalo nos tempos vagos para participar das conversas sobre o estágio e por muitas vezes foram eles que me lembraram de ligar o gravador. Muitos me disseram que tiveram dificuldade de tempo para escrever diários porque, além das tarefas da universidade e do próprio estágio, a maior parte deles trabalhava. Mesmo assim, quase todos me enviaram textos sobre a preparação e execução da regência. Eu me sinto muito agradecida por ter tido a oportunidade de aprender tanto com essas pessoas maravilhosas que realmente me acolheram no meu processo de pesquisa enquanto eles me acompanhavam durante o estágio no IFRJ. A seguir, explico como a pesquisa foi se transformando.

\section{4 O processo de pesquisa e algumas mudanças no caminho}

Inicialmente, quando submeti meu projeto para me candidatar à admissão no Doutorado em Estudos da Linguagem na PUC-Rio no final de 2014, meu objetivo era analisar as coconstruções de crenças (e sua relação com emoções e identidades) dos docentes em formação durante o estágio em IFE e minha proposta de pesquisa englobava os estagiários recebidos no instituto durante um ano (todos que acompanhassem minhas aulas), todos os professores de IFE que fossem regentes desses licenciandos e as duas professoras de Prática de Ensino. Já no segundo ano do Doutorado, submeti meu projeto ao Comitê de Ética em 
Pesquisa da PUC-Rio e obtive a aprovação (cf. documento 2016-49, no Anexo). Meu projeto, naquele momento, já tinha se transformado, sendo a maior modificação a seleção dos participantes.

Decidi restringir o foco aos licenciandos porque era patente, naquele momento específico da vida em nossa comunidade de prática, a nossa preocupação sobre a nossa falta de conhecimento sobre quem eram esses (futuros) professores que recebíamos e a discussão sobre como poderíamos coconstruir o estágio contando com a colaboração de todos. Havia uma grande inquietação sobre o que estávamos fazendo no estágio no IFRJ, principalmente por não entendermos nossas próprias identidades naquele contexto, o que acabou surgindo nos dados como uma das perguntas de Elis: Onde que a gente se encaixa aqui?

Após a geração dos dados, na releitura das transcrições das participações dos estagiários, bem como de suas produções escritas sobre o período de préserviço, o projeto sofreu novamente alteração, dessa vez quanto à organização da arquitetura teórica utilizada. Percebi o quanto as identidades fluíam nos dados e comecei a questionar como elas eram (re)construídas na linguagem e como essas escolhas influenciavam no processo dos estagiários de tornarem-se professores durante o estágio em nossa comunidade de prática de IFE. Portanto, minhas perguntas foram se modificando durante a pesquisa devido à minha percepção sobre os dados, o que fez com que parecesse mais relevante eleger o construto identidade como porta de entrada para continuar a investigação.

Como mencionei na seção 5.2.2, tivemos muitos problemas com alguns estagiários nos anos anteriores, mas, diferente de outras equipes que se afastaram e acabaram por abandonar o estágio, buscamos uma aproximação com os estagiários. Entendemos que era preciso promover o engajamento em nossas práticas a fim de tornar o estágio mais proveitoso para todos. Mas acredito que, além de orientá-los, é necessário escutá-los e procurar conhecê-los melhor. Em vista disso, optei por manter o foco nesses participantes para a tese, adiando, para pesquisas posteriores, a dedicação às coconstruções de identidades, crenças e emoções de todos os professores em formação envolvidos no estágio. Elis foi a licencianda que mais participou da pesquisa e este fato foi decisivo para a minha escolha de me concentrar nas interações das quais ela fez parte para elaborar o projeto de qualificação. Tal projeto apresentava a análise de três das produções escritas de Elis que eu entendia como representativas de diferentes momentos de sua trajetória identitária no período de pré-serviço de IFE, conforme mostra o quadro 4: 
Quadro 4 - Dados selecionados para análise na etapa de qualificação DADOS MOMENTO DO ESTÁGIO

10. Perguntas iniciais Respondidas na primeira reunião no instituto

2.. Diário 1 Após decorridas as primeiras três semanas de estágio

3․ Memorial de estágio Feito após o término do estágio.

Fonte: Quadro de minha autoria apresentado em meu exame de qualificação

Essa divisão preparada para a qualificação não se mostrou adequada porque acabava por expor cada um desses momentos como se fossem estanques quando, na verdade, os entendimentos gerados estavam todos conectados. A partir das análises nessa etapa de qualificação, observei que algumas identidades eram mais proeminentes e interligadas a outras e elas se repetiram quando expandi minha análise para outros dados escritos e orais de Elis: suas identidades-crenças-emoções como estagiária, como (não) futura professora e como membro da comunidade de prática de IFE. Por isso, decidi reorganizar a análise dos dados com base nesses três grupos tentando mostrar as interconexões entre eles a todo momento. Portanto, essa é apenas uma forma de apresentar minhas interpretações dos dados gerados nesta pesquisa, mas reitero que está tudo interconectado no caminhar identitário de Elis.

Assim, seguindo o que 'os dados me diziam', levando também em consideração as minhas próprias experiências, sentimentos, crenças e aprendizados durante o desenvolvimento da pesquisa, o foco do estudo se tornou a trajetória identitária de Elis, sua interconexão com crenças e emoções e como identidades-crenças-emoções emergiam na linguagem, bem como se elas eram ressignificadas ao longo do período de pré-serviço. Para tanto, sigo uma visão socioconstrucionista de identidades, crenças e emoções (MOITA LOPES, 2003; BUCHOLTZ; HALL, 2005; BARCELOS, 2013; ZEMBYLAS, 2003) e recorro à Linguística Sistêmico-Funcional (THOMPSON, 2014a; HALLIDAY, 1994; HALLIDAY; MATTHIESSEN, 2014; EGGINS, 2004; GOUVEIA, 2009) para analisar como elas são construídas discursivamente nos dados.

É importante mencionar que minha pesquisa com professores em formação no contexto de IFE, da qual o estudo aqui apresentado faz parte, mostra minha afinidade teórica com os princípios da Prática Exploratória (ALLWRIGHT, 2003; GIEVE; MILLER, 2006; TROTMAN, 2018), por exemplo, em minha preocupação com a qualidade de vida, no sentido de que busco privilegiar o compartilhamento de conhecimentos e aprendizagem mútua, bem como criar espaços que fortaleçam o relacionamento interpessoal enquanto negociamos significados (dentre eles crenças, emoções e identidades), mas atenta para que a pesquisa seja integrada às nossas atividades do dia-a-dia e não se torne onerosa de alguma 
forma. Também inspirada nessa abordagem, assumo meu lugar como agente reflexivo (MORAES BEZERRA; MILLER, 2018) com o objetivo de trabalhar para entender (ALLWRIGHT; HANKS, 2009; MILLER, 2013) questões emergentes em meu próprio contexto buscando envolver o grupo de professores em formação no estágio nessa empreitada.

\section{5}

\section{A geração de dados e os procedimentos de análise}

Ao longo do processo de pesquisa, os estagiários foram convidados a colaborar de diferentes formas, a saber: responder quatro perguntas na primeira reunião no instituto; produzir diários durante todo o processo; participar da gravação em áudio de algumas de nossas conversas durante o estágio e das conversas para a avaliação das regências; fazer um relato final oral sobre o estágio, que poderia ser gravado em vídeo ou apenas em áudio; e disponibilizar seus memoriais de estágio e de formação. No total, o grupo de estagiários participantes da pesquisa, que, necessariamente, acompanhavam minhas aulas regularmente, foram oito, dos dezoito que recebemos em 2016. Quatro deles estavam sob minha responsabilidade e quatro tinham a professora Maria como regente. Assim, como eu não tinha licenciandos em minhas aulas que fossem de outros regentes, somente os meus e os da professora Maria foram incluídos em meu estudo. Por fim, os dados gerados foram:

1. Respostas a quatro perguntas iniciais (feitas nos dias de reunião, antes do início do estágio) de todos os quinze licenciandos que quiseram participar da pesquisa naquele semestre;

2. Duas entradas em diário de Elis (uma após as três primeiras semanas de estágio e a outra sobre a regência) e meus próprios diários. Oito estagiários me enviaram diários apenas sobre o processo da regência;

3. Sete memoriais de estágio (incluindo o de Elis)

4. Conversas em onze encontros gravados em áudio, cinco dos quais Elis participou;

5. Seis conversas sobre as avaliações das regências (de 20 a 60 minutos cada), gravadas em áudio, incluindo a de Elis; 
6. Seis vídeos finais dos licenciandos falando sobre suas experiências no estágio, um deles o de Elis.

Como podemos perceber, Elis participou de todas as partes da pesquisa. O quadro 5 resume quais dados foram selecionados para a análise.

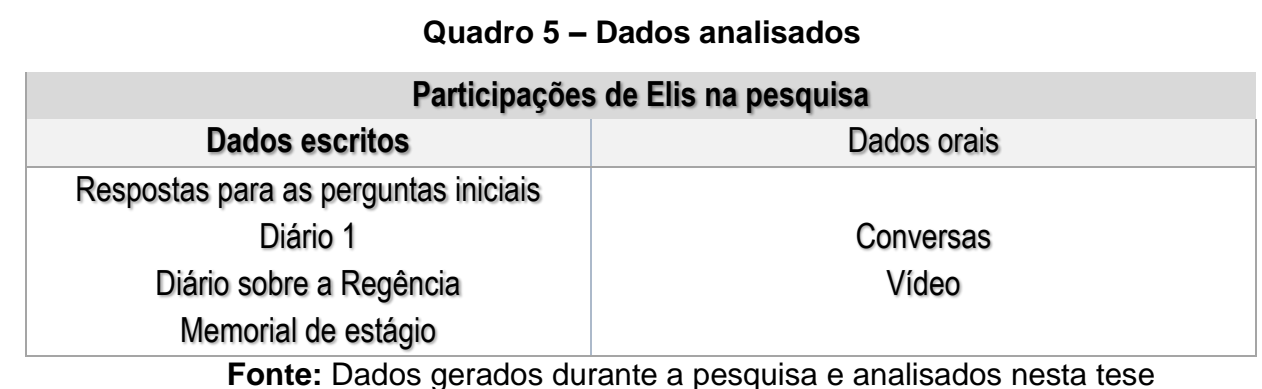

Foram muitos os dados gerados envolvendo diferentes gêneros, cada um com seu contexto e tendo sido escolhidos para integrar esta tese por diferentes razões. Nas próximas subseções, discorro brevemente sobre cada um deles.

\subsection{1 \\ As respostas para as perguntas iniciais}

As perguntas iniciais foram elaboradas por mim com o propósito de conhecer um pouco das expectativas e concepções dos licenciandos sobre o estágio em IFE antes de apresentarmos o contexto de nossa comunidade de prática e de eles acompanharem qualquer aula nossa. Dessa forma, na reunião para o acolhimento dos estagiários, sem ter ainda contato com as aulas de estágio propriamente ditas, Elis, assim como os outros licenciandos, escreveu respostas breves para as seguintes perguntas: a) Como é desenvolvido o ensino de inglês no médio técnico?; b) O que você entende por LinFE (Línguas para Fins Específicos)?; c) Quais são suas expectativas quanto ao estágio e sua vivência no IFRJ?; e d) Você acha que o estágio pode influenciar sua formação docente de alguma forma? Por que (não)?

\section{5 .2}

\section{Os diários}

Os diários podem ser fontes ricas e sistemáticas de informações e momentos de reflexão crítica (ZABALZA, 2004; LIBERALI; MAGALHÃES; 
ROMERO, 2003; LIBERALI, 2009) para todos nós, docentes em formação, e, por isso, sugeri a produção contínua dos mesmos desde o início do estágio. Concebo que, ao descrevermos o que vivenciamos, acreditamos e sentimos, muitas outras perguntas surgem, nos fazendo pensar especialmente em quem somos e/ou estamos sendo e/ou nos tornando. Portanto, minha intenção não é a de promover reflexão para mudanças pela ação, mas sim gerar questionamentos e procurar entender nosso processo de nos tornarmos professores.

Tentei motivá-los a escrever diários e trazer seus questionamentos para conversarmos em nossos encontros falando da importância desses textos e trazendo os meus para discutirmos juntos. Infelizmente, a maior parte dos estagiários que acompanharam minhas aulas durante o ano de 2016 não se engajou na produção constante desses textos e me enviaram apenas uma entrada em diário, todos após o dia da regência ${ }^{34}$, sempre descrita como um momento muito marcante para eles. Todas as vezes em que eu perguntava sobre seus diários, os licenciandos diziam que ainda não estavam escrevendo por ser difícil encontrar um tempo entre todas as suas tarefas para produzi-los.

Elis enviou duas entradas em diário para mim, que foram escritas em dois momentos diferentes durante o estágio: um logo após a minha conversa sobre a produção desse gênero e a outra após a realização da regência. De seu segundo diário, apenas pequenos trechos foram utilizados na análise. Seus textos são muito importantes para entender sua caminhada identitária para tornar-se professora já que descrevem alguns de seus questionamentos durante o estágio; suas impressões quanto a esse processo, aos professores envolvidos, à escola $\mathrm{e}$ aos alunos; bem como algumas de suas crenças e sentimentos, que transbordam em seus textos e, por vezes, são (re)formulados no mesmo.

\subsection{3}

\section{As conversas durante o estágio}

Devido aos objetivos desta tese, planejei gerar dados durante algumas das interações entre os professores em formação. Por isso, dialoguei com professores regentes, estagiários e professores de Prática de Ensino sobre a possibilidade de gravarmos nossas conversas em áudio antes de iniciar a pesquisa, o que foi muito bem recebido por todos os que aceitaram o convite participar da mesma. Somente

\footnotetext{
${ }^{34}$ Oito estagiários escreveram sobre todo o processo de desenvolvimento, apresentação e avaliação da regência e me enviaram seus textos durante a fase em que cumpriam as horas finais de estágio.
} 
após ter a permissão e a autorização assinada pelos participantes, comecei a gravar alguns de nossos encontros.

As conversas aconteciam nos intervalos e tempos vagos. Muitas acabaram não sendo gravadas pois ficávamos tão envolvidos nos assuntos que nem nos lembrávamos de ligar o gravador. Em nosso tempo juntos, os estagiários perguntavam sobre suas dúvidas, nós combinávamos o que faríamos para as próximas aulas e eu tentava orientá-los (quanto ao IFE, à elaboração de materiais, o planejamento de nossas aulas e ao funcionamento de uma escola, entre outros), mas nossas conversas não se restringiam a isso. Era comum, por exemplo, falarmos sobre o dia-a-dia do estágio (sobre nossas impressões quanto aos tópicos ou situações que surgiam nas aulas) e começarmos a contar outras histórias que vivenciamos e a discutir sobre nossas perspectivas, entendimentos e sentimentos, o que não se limitava apenas ao contexto de estágio. Oito desses encontros foram transcritos dos áudios, mas apenas os seis nos quais Elis esteve presente são mencionados na análise. Elis ficou em silêncio no primeiro deles e, por isso, essa conversa não está listada no quadro 6 e nos anexos.

Nas semanas finais de estágio, eu e Maria tivemos a oportunidade de nos reunir duas vezes com um grupo de licenciandos que acompanhavam as minhas turmas e as dela para conversarmos sobre o que estávamos fazendo no estágio e debater algumas leituras sobre textos específicos da abordagem usada nas aulas de inglês no instituto (o IFE). Nós combinamos de cada um trazer um texto à sua escolha e preparar uma apresentação sobre ele destacando alguns pontos para a discussão em grupo. A primeira dessas reuniões também foi gravada e alguns trechos foram analisados neste trabalho.

Outro momento de geração de dados foi a avaliação da regência, que reúne os professores regentes e de Prática de Ensino e os estagiários para analisar não só a aula dada pelo licenciando, mas também como se desenvolveu o estágio como um todo. Tal avaliação ocorre em três etapas. Na primeira delas, as professoras observam e fazem anotações sobre as regências executadas pelos licenciandos. Na segunda etapa, os estagiários deixam a sala e as duas professoras, sem a presença de nenhum outro participante, avaliam oralmente três aspectos: 1) a aula que acabou de ser apresentada; 2) o estagiário como "aprendiz" na universidade e no estágio, bem como sua atuação como professorcolaborador no estágio e 3) as impressões das duas quanto ao processo como um todo. Normalmente, a professora responsável pelo estagiário (que no caso de 
Elis, seria Maria, mas esta última precisou ser substituída por $\operatorname{mim}^{35}$ no dia da regência) e a Professora de Prática de Ensino fazem a média de suas notas e, em um terceiro momento, os estagiários são chamados de volta à sala para conversar sobre suas regências e as avaliações feitas pelas professoras.

Por fim, para esta tese, foram analisados alguns dos excertos de cinco das conversas entre Elis e outros participantes da pesquisa. A escolha dos títulos para cada excerto foi feita de acordo com o que estava sendo discutido, tendo a maior parte deles sido nomeada com uma das frases de Elis. No quadro 5, podemos ver a lista de todos os excertos analisados e quem eram os professores em formação que estavam interagindo em cada conversa.

Quadro 6 - Lista das conversas e seus excertos analisados

Excerto 1 - "Pode falar"

Excerto 2 - "É uma aula de inglês mesmo"

Excerto 3 - "Eu não fiz curso"

Excerto 4 - "Fica uma coisa mais livre assim de se trabalhar

Excerto 5 - "Para mim é tudo novo"

Excerto $6-0$ acolhimento na escola de estágio

Excerto 7 - A questão da experiência

Elis

Enzo

Carla

Elis

Enzo

Carla

Ana

Elis

Enzo

Carla

Léa

Excerto 2 - "A gente faz um pouquinho de tudo"

Excerto 1 "O que eu queria que acontecesse"

Excerto 2 - "Onde que a gente se encaixa aqui?"

Excerto 3 - "Eles acabam virando mais pra gente"

Elis

Carla

Maria

Fábio

Lara

Excerto 1 - "Eu achei que eles gostaram e eu achei que eu consegui passar"

Elis

Excerto 2 - "Tô com medo de me dar uma nota mais alta do que eu mereço"

Carla

Fábio

Excerto 3- "Eu vou acabar me enrolando mais"

Excerto 4 - "Foi mais tranquilo do que eu pensei"

Fonte: Dados gerados durante a pesquisa e analisados nesta tese

\footnotetext{
${ }^{35}$ Por motivo de saúde, Maria não pode comparecer no dia da regência de Elis. Entretanto, naquele semestre, eu e Maria tínhamos acompanhado os grupos sob responsabilidade das duas e eu já estaria presente de qualquer forma nas regências de Fábio e Elis naquele sábado. Eu também já conhecia as turmas em que as aulas seriam implementadas, não sendo necessário que Flávia fosse a única professora formadora no processo de avaliação desses estagiários.
} 


\section{5 .4}

Vídeo

Uma das atividades propostas pela professora Maria a seus estagiários é a confecção de vídeos após o final do estágio. Nesses vídeos, eles poderiam falar de forma livre para outros licenciandos e para os professores regentes sobre sua experiência no IFRJ. Essa não é uma atividade obrigatória, mas muitos estagiários compartilham conosco seus vídeos mesmo alguns meses depois de já terem terminado totalmente o processo no instituto. O vídeo de Elis foi gravado no IFRJ na última semana de estágio e foi dividido em dois excertos, que foram nomeados com frases por ela usadas em cada um deles: o excerto 1 tem como título "Agora eu quero ser professora de IFE" e o 2 foi nomeado como "Está tudo muito mais ligado do que a gente pensa". Esse vídeo foi inserido nas análises porque nele Elis relaciona o estágio, o IFE e algumas de suas (re)construções identitárias a partir de suas interações conosco.

\subsection{5 \\ O memorial de estágio}

O memorial de estágio, por sua vez, foi escolhido para integrar os textos analisados neste estudo porque, ao mesmo tempo que pode ser usado para avaliar as ações, ideias, impressões e conhecimentos de Elis sobre o estágio, ele objetiva promover a reflexão sobre esse período, como também pode trazer as emoções que são ligadas aos momentos, pessoas e ambientes descritos (PRADO; SOLIGO, 2005). De acordo com Reis e Santos (2013, p. 1), por meio de memoriais, o professor de Prática de Ensino pode "ter uma melhor percepção" de como seus alunos "compreendem e, sobretudo, vivenciam o curso" para desenvolver abordagens de construção de saberes docentes que possibilitem uma formação de professores "mais completa, de caráter mais humanista". Acredito que eles também poderiam ser discutidos com os professores regentes visando os mesmos objetivos. Devemos lembrar, porém, que esses textos são também uma ferramenta de avaliação final da disciplina de Prática de Ensino.

Assim, os memoriais são textos escritos, formatados como um trabalho de disciplina da graduação, que tem diferentes propósitos comunicativos, a saber: avaliar o processo de estágio; fazer os alunos organizarem sua experiência de forma escrita, descrevendo sua atuação e suas impressões sobre as aulas, bem como o ambiente e as pessoas, trazendo sempre uma reflexão crítica sobre o 
período de pré-serviço; contar parte da história de formação do autor; e servir de base para o próprio professor de Prática de Ensino pense sobre como o estágio está se desenvolvendo e avalie a necessidade de mudanças na prática de estágio em turmas futuras. Portanto, normalmente, os memoriais são lidos somente pela professora de Prática de Ensino, mas foram cedidos por alguns dos licenciandos que participaram deste estudo para a geração de dados desta pesquisa.

Nos últimos encontros com os licenciandos no instituto, perguntei se eles poderiam me enviar seus memoriais, mas sabia que eles só me mandariam seus textos meses depois, quando já tivessem cumprido toda a carga de estágio. No caso de Elis, o estágio de IFE no instituto foi o primeiro a ser finalizado. Depois disso, ela ainda fez parte do estágio de Língua Portuguesa no instituto, mas só o concluiu no colégio de aplicação de sua universidade. Ela também fez alguns meses de estágio em uma escola estadual próxima à sua casa. Assim, o memorial de Elis só foi escrito depois de findados todos esses estágios e ela o organizou nas seguintes partes:
a. Introdução (avaliação do estágio como um todo)
b. Inglês no instituto
c. Português no instituto
d. Português no colégio de aplicação
e. Português e inglês em uma escola estadual próxima à sua casa

Apesar de ter ciência da riqueza de entendimentos proporcionada pela leitura do memorial como um todo, devido ao escopo deste estudo, apenas seu parágrafo introdutório e a seção sobre o inglês no instituto foram analisados. A porção investigada do memorial encontra-se no Anexo como no original, em texto corrido, sendo apenas excluída a parte final que trata dos estágios em outras disciplinas e escolas, bem como modificados os nomes dos participantes da pesquisa.

Por fim, foram selecionados para a análise os dados escritos por Elis, o vídeo feito por ela e as conversas das quais a licencianda fez parte. Atendendo os objetivos apresentados na introdução desta tese e de acordo com a fundamentação teórica escolhida, procedi à transcrição das conversas e do vídeo. Depois, iniciei a leitura cuidadosa de todos os dados considerando os contextos situacional e cultural em que foram produzidos, busquei investigar que identidades emergiam, seguindo os princípios propostos por BUCHOLTZ E HALL, 2005. Ao mesmo tempo, procurei identificar os elementos avaliativos na linguagem e analisar como eles estavam relacionados ao processo identitário da estagiária. 
Como explicado na seção 5.4, a partir do recorte selecionado para a minha qualificação e depois da primeira análise de todos os dados selecionados para a tese, foram identificados três grandes blocos semânticos (que foram organizados nas subseções 6.1.1, 6.1.2 e 6.1.3) que utilizei como uma forma de agrupar as (re)construções identitárias de Elis durante o estágio: suas identidades-crençasemoções como estagiária, como (não) futura professora e como membro da comunidade de prática de IFE. Com exceção às respostas para as perguntas iniciais, todos os outros dados foram divididos em excertos para que fosse possível mostrar as interconexões entre diferentes momentos da trajetória identitária de Elis. Assim, os excertos não seguem necessariamente a sequência numérica no capítulo de análise (Capítulo 5), mas eles se encontram dispostos em sua ordem original nos Anexos. O quadro 7 sintetiza a organização da análise dos dados no Capítulo 5:

Quadro 7 - Organização da análise

\begin{tabular}{|c|c|}
\hline SEÇÕES & DADOS \\
\hline Algumas (re)construções de Elis como estagiária & $\begin{array}{l}\text { Respostas das questões iniciais } \\
\text { Conversa } 1 \text { - Excertos 1, 2, 3, } 5 \text { e } 6 \\
\text { Conversa } 4 \text { - Excerto 1, } 2 \text { e } 3 \\
\text { Conversa } 5 \text { - Excertos 1, 2, } 3 \text { e } 4 \\
\text { Diário sobre a Regência Excerto } 2\end{array}$ \\
\hline $\begin{array}{l}\text { Algumas (re)construções de Elis como (não) futura } \\
\text { professora }\end{array}$ & $\begin{array}{l}\text { Conversa } 1 \text { - Excerto } 7 \\
\text { Conversa } 2 \\
\text { Diário } 1 \text { - Excertos 1, 2, 3, 4 e } 5\end{array}$ \\
\hline $\begin{array}{l}\text { Algumas (re)construções de Elis como membro da } \\
\text { comunidade de prática de IFE }\end{array}$ & $\begin{array}{l}\text { Vídeo - Excertos } 1 \text { e } 2 \\
\text { Conversa } 1 \text { - Excerto } 4 \\
\text { Conversa } 3 \text { - Excertos } 1 \text { e } 2 \\
\text { Memorial de estágio - Excertos 1, 2, 3, 4, 5, 6, } 7 \text { e } 8 \\
\text { Diário sobre a Regência - Excertos } 1 \text { e } 3\end{array}$ \\
\hline
\end{tabular}

Fonte: Dados gerados durante a pesquisa e analisados nesta tese

Na última parte da análise (seção 6.2), retomo as questões de pesquisa e apresento algumas reflexões que podem contribuir para entendê-las, traçando, para tanto, conexões entre as principais ideias discutidas na seção 6.1 a partir do embasamento teórico proposto para o desenvolvimento deste trabalho. Assim, não ofereço respostas, mas entendimentos possíveis que foram construídos ao longo da caminhada do estágio de Elis e desta pesquisa. 


\title{
Análise e discussão dos dados
}

\begin{abstract}
We need to be mindful of who our teachers are, where they are in cognitive, affective, and experiential terms, how they are experiencing both being and becoming teachers, and what we collectively are attempting to accomplish throughout our time together ${ }^{36}$.
\end{abstract}

(JOHNSON; GOLOMBEK, 2016, p. 164)

Este capítulo se propõe a apresentar uma possibilidade de análise dos dados gerados nesta pesquisa com base no arcabouço descrito na fundamentação teórica (cf. capítulos 2, 3 e 4) a partir de minhas interpretações, que partem do meu contexto e são influenciados pelas minhas identidades, crenças e emoções. Lembro que esta pesquisa busca criar inteligibilidades sobre o estágio, momento em que estamos 'vivenciando ambos ser e nos tornar professores' e tem como foco as (re)construções identitárias da licencianda Elis em um contexto de estágio em uma comunidade de prática de IFE, considerando também a influência de suas crenças e emoções nesse processo segundo a perspectiva da Linguística Sistêmico-Funcional.

Mais detalhadamente, analiso os dados selecionados a partir de um prisma sociossemiótico, especialmente segundo o Sistema de Avaliatividade (MARTIN; WHITE, 2005), conforme explicado no capítulo 4. Recorro também ao arcabouço teórico sobre identidades, crenças e emoções (BARCELOS, 2012; BUCHOLTZ; HALL, 2005; (MOITA LOPES, 2003; ZEMBYLAS, 2004) ao qual me alinho (cf. capítulo 3), dentre eles os princípios propostos por Bucholtz e Hall (2005) por entender as identidades como discursivamente construídas.

\section{1}

\section{Algumas (re)construções identitárias de Elis no processo de tornar- se professora}

Nesta seção, algumas das identidades de Elis em sua caminhada no processo de tornar-se professora são destacadas e interpretadas com base nos contextos de suas produções escritas e orais no decorrer do estágio. Com o objetivo de organizar os dados para a análise, eles foram separados em três

\footnotetext{
${ }^{36}$ Nós precisamos estar conscientes de quem nossos professores são, onde eles estão em termos cognitivos, afetivos e experienciais, como eles estão vivenciando ambos ser e se tornar professores, e o que nós coletivamente estamos buscando realizar durante o nosso tempo juntos
} 
subseções formando grandes blocos: as (re)construções identitárias de Elis como estagiária, como (não) futura professora e como membro da comunidade de prática de IFE.

No entanto, dentro de cada subseção, diferentes identidades emergem concomitantemente, sendo possível, em alguns momentos, perceber a confluência de identidades que são discutidas de forma mais detalhada em outros blocos. Sendo assim, considero que as subseções não são estanques, pois parto da premissa que as identidades analisadas são múltiplas, fragmentadas e fluidas (MOITA LOPES, 2003) e são (re)construídas na linguagem a todo momento como um fenômeno cultural e social, dependente da interação e do contexto de forma complexa. Para facilitar a visualização, estarão destacados, em negrito, os elementos referentes à arquitetura teórica (cf. capítulos 2, 3 e 4) e, em itálico, algumas das identidades que emergem nos dados. Passemos, então, às análises.

\subsection{1 \\ (Re)construções de Elis como estagiária}

Inicio a análise pelo primeiro contato que tive com Elis na reunião em que ela e seus colegas estagiários redigiram suas respostas para quatro perguntas escritas. Nesse encontro, predominavam a motivação misturada à insegurança e à ansiedade (principalmente pelo enfrentamento com o desconhecido): apesar de se mostrarem muito animados e dispostos a aprender, nós professores de IFE e os estagiários não nos conhecíamos pessoalmente, eles pouco sabiam sobre o estágio em nossa escola e pareciam preocupados com o que chamavam de 'inglês técnico' (temor que pode ter sido gerado juntamente com crenças negativas alguns dos mitos sobre IFE discutidos na seção 2.1.3). Algumas dessas primeiras impressões, que registrei em meu diário, podem também ser percebidas na produção escrita de Elis para as questões iniciais:

\section{Respostas de Elis para as questões iniciais}

\begin{tabular}{|r|l|}
\hline 1 & a) Como é desenvolvido o ensino de inglês no ensino médio técnico? \\
\hline 2 & Imagino que o foco seja que os alunos aprendam termos relacionados \\
\hline 3 & a sua área de interesse e saibam lidar com situações em que a língua \\
\hline 4 & inglesa seja usada. \\
\hline 5 & b) o que você entende por LinFE (Línguas para Fins Específicos) ? \\
\hline 6 & Por enquanto ainda não sei muito sobre o assunto, mas imagino que \\
\hline 7 & envolva vocabulário e termos técnicos voltados para uma área específica. \\
\hline 8 & C) Quais são suas expectativas quanto ao estágio e a sua vivência no IFRJ? \\
\hline 9 & Espero aproveitar ao máximo a minha experiência, ter um bom convívio \\
\hline 10 & com os alunos e professores com os quais tiver contato e auxiliar os \\
\hline
\end{tabular}




\begin{tabular}{|l|l|}
\hline 11 & alunos no que precisarem. \\
\hline 12 & d) Você acha que o estágio pode influenciar sua formação docente de alguma \\
\hline 13 & forma? Por que (não) ? \\
\hline 14 & Sim, porque este é meu primeiro estágio na área docente e gostaria de \\
\hline 15 & saber se é algo que me vejo fazendo no futuro. \\
\hline
\end{tabular}

As respostas de Elis, como também algumas de minhas perguntas, sugerem a fragilidade daquele momento: tudo ainda estava no campo da incerteza, da imaginação e da expectativa, o que pode ter fomentado o uso constante de processos mentais (ver Sistema de Transitividade, na seção 4.1) como imagino, espero, não sei, gostaria de saber. Por essas opções, é possível interpretar que, em suas respostas, Elis se constrói como alguém 'de fora', não só da comunidade de prática de LinFE, mas também da dinâmica do estágio em si, como alguém que ainda não pertence àquele contexto pois não sabe muito sobre ele, só imagina, mas que está ali para aprender (como sugerem as linhas 9 a 11, onde ela diz que quer 'aproveitar, ter contato, auxiliar, saber'), uma estagiária aprendiz e inexperiente na docência, no estágio e no IFE. Mesmo os processos que não são mentais estão a eles subordinados, como, por exemplo, a escolha de ligar os processos 'aproveitar', 'ter' e 'auxiliar' ao processo 'espero', o que nos remete ao contexto de incerteza, desconhecimento e motivação descrito. Percebemos, nesse exemplo, como sua perspectiva está dentro do domínio de afeto (ver Sistema de Avaliatividade, seção 4.3), que permeia todos os seus dados.

Em um de nossos encontros finais, transcrito na Conversa 4, retomamos as questões iniciais para discuti-las novamente e Elis reelabora algumas de suas crenças-identidades-emoções iniciais questionando o que escrevera em suas respostas. Para tanto, ela usa uma explicação, da qual depreende-se que suas escolhas lexicogramaticais estavam mais ligadas, em nível semântico, ao seu desejo (ao que ela queria que acontecesse), também no campo atitudinal de afeto.

Conversa 4 - Excerto 1 - 0 "que eu queria que acontecesse"

\begin{tabular}{|l|l|l|}
\hline 1 & Elis & porque eu botei tudo ... o que eu imaginava...o que eu esperava... \\
\hline 2 & & as expectativas... no sentido do que eu queria que acontecesse (.) \\
\hline 3 & & não do que eu achei que ia acontecer ... aí eu botei por exemplo \\
\hline 4 & & "espero aproveitar ao máximo a minha experiência e ter um bom \\
\hline 5 & & convívio com os alunos e professores com os quais eu tiver contato \\
\hline 6 & & e auxiliar os alunos no que precisarem" ( (lendo) ) aí eu achava que \\
\hline 7 & & eu ia ter muito contato com os alunos e não tanto com vocês ... \\
\hline 8 & & e eu acho que no final das contas eu acabei me envolvendo \\
\hline 9 & & mais com vocês do que com os alunos \\
\hline 10 & Maria & é verdade \\
\hline
\end{tabular}


Assim, tanto na escrita (nas respostas para as questões iniciais) como na fala (no Excerto 1, Conversa 1), cada uma em um momento distinto de sua caminhada, as escolhas de Elis parecem dar maior proeminência ao fato de ser impossível desassociar crenças, emoções e identidades (cf. seção 3.5.3.): ela se constrói como estagiária iniciante inexperiente, expectante e insegura, a partir de suas crenças e emoções (o que pode ser entendido, por exemplo, em 'espero aproveitar..., ter..., auxiliar...', 'imaginava' e 'queria que acontecesse'), que, ao mesmo tempo, são constituídas por seu processo identitário.

Entretanto, cabe salientar que, na Conversa 4, essas identidades-crençasemoções emergem como uma referência ao passado, ao que ela estava sentindo/acreditando/sendo nos momentos iniciais de estágio, mas que foram reformuladas. Assim, ela abre caminho para reconstruir-se como alguém que não se sente/acredita/está sendo mais assim, posto que fala de uma outra posição (outro momento no processo de tornar-se professora e outro contexto), já como membro da comunidade de prática ${ }^{37}$ e estagiária experiente. Isso exemplifica como as identidades podem ser transitórias e locais, como explicado pelo princípio de posicionalidade (BUCHOLTZ; HALL, 2005). Com base nesse princípio, reitero que, mesmo quando utilizo a mesma nomenclatura em diferentes instâncias, essas identidades são sempre ressignificadas de acordo com cada contexto situacional e cultural.

Tanto pelas respostas às questões iniciais quanto pelo Excerto 1 da Conversa 4, pode-se interpretar que Elis expõe a sua inexperiência e falta de conhecimento como uma situação temporária, já que ela tinha como objetivo se inteirar sobre aquele novo ambiente, aprender e se integrar a ele. Isso está implícito no texto quando ela lista o que esperava fazer (linhas 6 a 8 das respostas e partes lidas na Conversa 4) e pela seleção das circunstâncias 'por enquanto' e 'ainda' (linha 4 das respostas). Até mesmo o uso de ambas as circunstâncias é um reforço à essa ideia, pois elas expressam a mesma noção de 'por ora é assim, mas podem haver mudanças'. Portanto, pode-se considerar que sua construção como estagiária aprendiz e inexperiente está atrelada à crença de que o estágio poderá trazer transformações e talvez ajudá-la no processo de tornar-se professora (linhas 14 e 15 nas respostas).

É importante lembrar que, como explicado na seção 5.5.3, Elis não falou na primeira interação registrada em áudio na qual estava presente. Isso pode ter

${ }_{37}$ Ver seção 6.1.3, que discute especificamente as (re) construções de Elis como membro da comunidade de prática de IFE e retorna à Conversa 4 para análise de outros excertos. 
acontecido por vários motivos (dentre eles o fato de ela ser a única participante de sua turma de Prática de Ensino, por ter muitas pessoas na conversa e maior dificuldade para ter o turno ou até por causa do assunto, que era o que havia sido discutido na universidade sobre o estágio), que podem não ter proporcionado espaço e segurança para que Elis participasse verbalmente naquele momento. De qualquer forma, acredito que desse seu silêncio também emergem identidades como estagiária insegura/ novata na comunidade de prática (e também em relação à esta pesquisa) e talvez ela precisasse coconstruir conosco sua confiança/segurança para falar. Cabe salientar que, apesar de considerar que ouvir e observar também fazem parte do estágio, acredito que a participação deva se expandir e que a integração do estagiário é responsabilidade de todos, sendo essa última uma das premissas que me motivou ao desenvolvimento da presente pesquisa. Assim, a partir da minha reflexão sobre esse encontro, senti a necessidade de tentar criar com eles mais oportunidades para ouvir a todos.

Em um segundo encontro audiogravado do qual Elis fez parte ${ }^{38}$, que foi nomeado como Conversa 1, vemos a transcrição de sua interação comigo e com Enzo, que parece ilustrar como as identidades de Elis (de todos nós, na verdade) vão se reconstruindo enquanto negociamos significados.

\section{Conversa 1 - Excerto 1 - "Pode falar"}

\begin{tabular}{|r|l|l|}
\hline 1 & Carla & E aí gente... queria saber assim as primeiras impressões \\
\hline 2 & & que vocês tiveram... assim do estágio desde u: (.) a reunião que \\
\hline 3 & & nós fizemos né? para receber os estagiários (.) o que \\
\hline 4 & & vocês estão achando da escola....? \\
\hline 5 & Enzo & pode falar, Elis. ( (Elis ri)) não tem problema não... sempre eu \\
\hline 6 & & que começo ... ela vai editar isso depois no áudio (.) \\
\hline 7 & & ( (Enzo e Elis rindo) ) melhores momentos \\
\hline 8 & Carla & tanto faz, gente \\
\hline
\end{tabular}

No Excerto 1, Enzo se posiciona como apoiador da colega, tentando tranquilizá-la e encorajá-la (em não tem problema não... ela vai editar isso depois no áudio... melhores momentos), o que é coconstruído com Elis também pelos risos de ambos. No entanto, ao mesmo tempo, algumas das escolhas constroem Enzo como mais assertivo, experiente e com maior autoridade que Elis: ele usa modulação (em Pode falar, na linha 5, que parece posicioná-lo como alguém que pode (dar permissão'), de forma a requerer a participação da colega, e modalização ${ }^{39} \mathrm{com}$ alto grau de usualidade (em

\footnotetext{
${ }^{38}$ Elis participou de muitas outras conversas antes desta, mas a Conversa 1 foi a segunda gravada em áudio com a presença dela.

${ }^{39}$ Ver modalidade, parte da metafunção interpessoal, na seção 4.2 .
} 
sempre eu que começo, que confere à sua fala ainda mais assertividade, até mesmo pelo anteposição do 'sempre') que, dentro do campo semântico do engajamento, contrai dialogicamente o discurso na tentativa de convencê-la a responder. Desse modo, entendo que, nessa interação, por indexicalidade e posicionalidade, Elis se coconstrói como participante da pesquisa e estagiária menos experiente e insegura (talvez por se sentir tímida e/ou preocupada com o fato de estar sendo gravada).

Elis continua calada e após eu, da minha posição naquele contexto como professora regente/pesquisadora, dar o aval para qualquer um dos dois seguir, Enzo toma o turno e levanta a discussão sobre crenças que envolvem a valorização dos docentes com licenciatura em inglês e o ensino dessa língua na escola e nos cursos livres, como podemos ver no Excerto 2 da Conversa 1.

Conversa 1 - Excerto 2 - "É uma aula de inglês mesmo"

\begin{tabular}{|c|c|c|}
\hline 9 & Enzo & eu gostei... achei bem legal (.) o que mais me chamou a atenção \\
\hline 10 & & foi a questão do uso de inglês na sala de aula porque... é (.) foi \\
\hline 11 & & até uma discussão que eu tive com a professora sobre a profissão \\
\hline 12 & & docente (.) que no Brasil o aluno só aprende inglês em curso de \\
\hline 13 & & inglês (.) infelizmente nós temos essa concepção né (.) parece que \\
\hline 14 & & o professor de inglês ... ele não está capacitado dentro da escola \\
\hline 15 & & de ensinar inglês para o aluno (.) se você quiser ensinar $e$ \\
\hline 16 & & aprender inglês você vai pro curso de inglês porque no curso de \\
\hline 17 & & inglês que tem profissionais suficientemente capacitados para \\
\hline 18 & & ensinar só que o mec não reconhece o curso de inglês como uma \\
\hline 19 & & escola então o curso de inglês não precisa contratar um professor \\
\hline 20 & & de inglês... apenas um instrutor de inglês (.) então como é que é? \\
\hline 21 & & tipo a gente estuda na faculdade ... fica quatro cinco seis anos... \\
\hline 22 & & deus sabe quanto tempo a gente fica estudando...para um simples \\
\hline 23 & & instrutor (.) não desmerecendo....mas não tem a questão \\
\hline 24 & & pedagógica (.) não tem a questão de língua que nós temos... um \\
\hline 25 & & instrutor que fez cinco anos de curso de inglês... chegar e dar \\
\hline 26 & & aula e ter o título pela sociedade de professor de inglês \\
\hline 27 & Elis & hurrum aquele [que ensina $\circ$ inglês] \\
\hline 28 & Enzo & [aquele que tem realmente a formação] \\
\hline 29 & & para ensinar inglês com conhecimento de inglês (.) quando tá na \\
\hline 30 & & escola tipo não ensina inglês na escola ...parece que é uma matéria \\
\hline 31 & & pra constar (.)mas quando eu cheguei aqui eu vi que não \\
\hline 32 & & o aluno ele pode aprender inglês sim na escola... porque aqui eles \\
\hline 33 & & aprendem inglês na escola (.) para fins específicos \\
\hline 34 & & e: é bem difícil o fins específicos também (.) achei isso BEM legal \\
\hline 35 & & só o ambiente de língua inglesa dentro de uma sala de aula \\
\hline 36 & & numa ESCOLA (.) pra mim foi um choque (.) eu não tava acostumado \\
\hline 37 & & porque eu estudei na faetec... e lá era inglês específico também \\
\hline 38 & & e a aula tinha um material em inglês... um material específico \\
\hline 39 & & para cada área... mas a aula não era em inglês \\
\hline 40 & & a aula era em português... pra mim também isso já foi um choque \\
\hline 41 & & com perspectiva positiva \\
\hline 42 & Elis & $\operatorname{sim}$ \\
\hline 43 & Carla & é legal porque assim (.) acredito que eles sentem \\
\hline 44 & Elis & que é uma aula de inglês mesmo né \\
\hline 45 & Carla & eles não ficam com medo porque tem um momento \\
\hline 46 & & de conscientização (.) e eu também falo português com eles \\
\hline
\end{tabular}


47 Enzo $\quad$ mas aí tem a questão do nível também... né?

48 Carla mas o português é uma ferramenta (.) não só aqui no básico

Algumas das crenças que emergem por escolhas dentro do Sistema de Avaliatividade na primeira fala de Enzo, das linhas 9 a 26, são: a) de que, no Brasil, nós (linhas 12 e 13) só confiamos nas aulas de inglês ministradas em cursos em detrimento do que é feito nas escolas, ao mesmo tempo que desvalorizamos o professor de inglês e sua formação acadêmica, o que é avaliado por afeto negativo de infelicidade (com infelizmente, na linha 13); b) de que há uma diferença entre 'professor' e 'instrutor' de inglês, sendo o primeiro aquele que 'estuda na faculdade' (o que exige grande sofrimento, recuperado do afeto implícito de insatisfação com gradação alta nas linhas 21 e 22) e o instrutor (avaliado por julgamento negativo de capacidade nas linhas 22 a 26) se restringe ao estudo em cursos livres e não está preparado para 'dar aula'; e c) de que é injusto que o instrutor 'tenha o título' de professor como a sociedade acredita (o que é construído por julgamento implícito). Elis parece se construir em alinhamento com as crenças/emoções que emergem na fala de Enzo (ao concordar e tentar completá-lo em hurrum aquele que ensina o inglês, nas linhas 27 e 28) como estudante de Letras e estagiária/ professora em formação. Ao mesmo tempo, ela se distingue (cf. distinção dentro do princípio de relacionalidade) dos instrutores por ecoar as avaliações negativas de Enzo sobre eles. Assim, apesar de Elis não desenvolver muito a sua fala aqui, ela se coconstrói na interação, o que ficará ainda mais claro na análise do Excerto 3.

No turno de Enzo iniciado na linha 29, ele reflete sobre algumas de suas crenças com base na experiência no estágio, às quais Elis vai se referir mais adiante. De início, duas crenças emergem por avaliações muito negativas: uma delas por apreciação, de que, na escola, inglês é geralmente uma 'matéria para constar'; e outra por julgamento, de que os professores, apesar de sua formação, 'não ensinam' a língua quando estão na escola. Essas duas parecem construir uma terceira crença, a de que o aluno não tem a possibilidade de aprender inglês na escola, o que pode ser depreendido também na reelaboração da mesma por Enzo, agora com avaliação positiva, em quando eu cheguei aqui eu vi que não (.) o aluno ele pode aprender inglês sim na escola (linhas $32 \mathrm{e}$ 33). Tal reformulação é feita também pelas avaliações de Enzo sobre o IFE por apreciação positiva com gradação alta como 'bem legal' e 'bem difícil também', comparando o IFE ao inglês ensinado em cursos livres, além de avaliar, 
também por apreciação, o uso da modalidade oral (em um choque com perspectiva positiva), crenças que parecem ser compartilhadas por Elis quando diz sim, na linha 43. Em outras palavras, ao confirmar a expectativa (o que também é um recurso avaliativo de engajamento de contração dialógica), Elis parece mostrar sua concordância com as proposições do colega e isso também cria solidariedade entre eles.

É relevante mencionar que essas avaliações sugerem que a participação de Elis e Enzo no estágio contribuiu para a desconstrução de pelo menos dois mitos sobre IFE listados na seção 2.1.3 (de que as aulas têm que ser sempre ministradas em português e de que quem não sabe inglês direito, vai dar aula de IFE). Entretanto, quanto ao uso da modalidade oral, parece que Enzo (das linhas 35 a 41) e Elis (nas linhas 42 e 44) constroem, por meio de avaliações muito positivas, a crença de que a validade do ensino de inglês está atrelada a ele e que o uso de português em sala é algo negativo.

O mesmo acontece com a escolha avaliativa de Elis por um tipo de gradação, chamada foco, na escolha de 'mesmo' (em que é uma aula de inglês mesmo, na linha 44) que sugere maior autenticidade ao item avaliado, que é 'a aula ser em inglês no IFRJ' (tópico previamente desenvolvido por Enzo). Nessa ocasião, Elis toma meu turno e parece tentar completar o que eu estava falando, talvez por entender que estávamos nos construindo em concordância quanto ao uso de português e inglês pelos professores nas aulas. Contudo, a partir de minha posição de membro mais experiente da comunidade de prática e professora regente deles, eu apresento uma perspectiva diferente, por meio de engajamento de contração dialógica (em eles não ficam com medo porque tem um momento de conscientização, e eu também falo português com eles mas o português é uma ferramenta, não só aqui no básico, nas linhas 45, 46 e 48), mostrando minhas crenças sobre o assunto como fatos que contestavam e poderiam fazê-los questionar as deles.

Infelizmente, diante de nossa coconstrução do meu posicionamento como 'professora regente ensinando os estagiários', com minha fala talvez entendida como uma correção, houve apenas um questionamento por parte de Enzo. Acredito que discordâncias, como a que aconteceu no Excerto 2 da Conversa 1, podem ser oportunidades de aprendizado mútuo e julgo que precisávamos de mais tempo para debater essas crenças. Ainda quanto à nossa interação, percebemos que, em boa parte do Excerto 2, os turnos de Enzo são longos e que Elis se restringe a concordar com o que está sendo dito, sem apresentar um novo 
ponto de vista, dinâmica que só é quebrada quando ela responde, no Excerto 3 (linhas 50 a 55), minha pergunta direcionada especificamente a ela.

Conversa 1 - Excerto 3 - “Eu não fiz curso”
\begin{tabular}{|r|l|l|l|}
\hline 49 & Carla & e você? ( (viro para Elis) ) quais são suas impressões? \\
\hline 50 & Elis & foi bom ele ter falado do curso de inglês porque eu não fiz curso... \\
\hline 51 & & e eu acho que muitos deles aqui talvez não tenham feito... então \\
\hline 52 & & achei que poderia ser uma forma em que eu poderia me \\
\hline 53 & & relacionar com eles ... mostrar pra eles que é possível você \\
\hline 54 & & aprender inglês sem ir pro curso (.) não não é uma... eles podem \\
\hline 55 & & também... né fazer i:sso (.)
\end{tabular}

No excerto 3, Elis se constrói como participante da interação (quando minha pergunta parece desconsiderar ou minimizar suas participações anteriores na mesma conversa) ao avaliar, por apreciação positiva, o fato de Enzo ter trazido o tema 'curso de inglês', vinculando o que ela queria dizer à discussão anterior. No entanto, Elis escolhe uma outra visada do tema e se constrói por meio de escolhas atitudinais evocadas, isto é, ao invés de sua perspectiva ser expressa explicitamente (ser inscrita), ela está subentendida, que são opções dentro do Sistema de Avaliatividade, como explicam Martin e White (2005). Por vezes, as identidades de Elis emergem em significados que devem ser recuperados do contexto, como no Excerto 3 aqui sob escrutínio.

Primeiramente, ao citar que nunca fez curso (na linha 50), Elis se apresenta em uma posição de destaque (cf. princípio de posicionalidade) por meio de julgamento positivo evocado de tenacidade, da qual ela desenvolve a identidade de exemplo para os alunos. Em seguida, Elis parece trazer essa experiência para ser vista com bons olhos pelos seus interlocutores e, por meio de julgamento positivo evocado de capacidade em '(achei que eu poderia) mostrar pra eles que é possível você aprender inglês sem ir pro curso (.) não não é uma... eles podem também... né fazer i:sso' emerge também a identidade de estagiária capaz e proativa (linhas 52 a 55). Ao mesmo tempo, nessas orações Elis se constrói por meio de crenças que a diferenciam daqueles que só confiam na eficiência do ensino de inglês em cursos livres (o que também remete à discussão no Excerto 2 e a mostram como participante atenta desde o início da conversa).

Além disso, em sua resposta repleta de modalização (como em eu acho, achei que poderia, eu poderia, nas linhas 51 e 52 do Excerto 3 da Conversa 1), emergem as identidades-crenças-emoções de estagiária cautelosa para se expressar, preocupada em criar vínculos com os alunos e de solícita para atendêlos (o que parece ser visto por ela como função do estagiário/professor), que a 
constroem como estagiária insegura e diligente. Pode-se interpretar ainda que a insegurança de Elis naquele contexto também se constitui por sua posição temporária como inexperiente na comunidade de prática, como também sugerem suas escolhas avaliativas no Excerto 5 da Conversa 1, mostrado a seguir:

Conversa 1 - Excerto 5 - "Pra mim é tudo novo"

\begin{tabular}{|r|l|l|}
\hline 93 & Carla & quando a gente se conheceu, perguntei sobre suas expectativas \\
\hline 94 & & vocês lembram? \\
\hline 95 & Enzo & ((rindo) ) já sumi com isso na minha vida (.) tento não criar \\
\hline 96 & & expectativas né (.) mas se eu comparar com o outro estágio em \\
\hline 97 & & inglês na rede estadual por exemplo (.) estou gostando \\
\hline 98 & Carla & o negócio é assim . . a minha... porque você já trabalha \\
\hline 99 & & né? ( (me dirigindo ao Enzo, que confirma gestualmente que sim) ) \\
\hline 100 & & você também já trabalha? ( (minha pergunta direcionada a elis) ) \\
\hline 101 & Elis & eu não (.) pra mim pra mim é TUDo diferente... pra mim é tudo \\
\hline 102 & & novo... tudo eu estou fazendo isso aqui pela primeira vez (.) e eu \\
\hline 103 & & não sabia que fazer estágio em uma escola técnica era uma \\
\hline 104 & & possibilidade ... assim eu achava que eu ia pra uma escola: \\
\hline 105 & & comu:m... aí é tudo muito novo (.) essa questão de produzir o \\
\hline 106 & & material... não ter que seguir um livro \\
\hline
\end{tabular}

Em sua fala no Excerto 5 da Conversa 1, entendo que Elis não só responde à pergunta sobre se ela já trabalhava (linha 100), mas que ela se refere ao que foi dito desde o início desse excerto e se (re)constrói como estagiária inexperiente não somente na docência, mas também no estágio e no IFE. Em primeiro lugar, o não de Elis como reposta à pergunta sobre o trabalho como docente, seguido do que pode ser interpretado como uma explicação da negativa (de que 'tudo é novo'), parece construí-la como inexperiente na docência. Além disso, Elis destaca o que está em voga é a perspectiva dela, fazendo questão de falar 'eu' (que poderia ser omitido em eu não) e repetindo o 'pra mim' três vezes na linha 100, o que ao mesmo tempo a identifica em relação aos outros participantes da conversa e a distingue de nós pelos princípios de indexicalidade e de relacionalidade (BUCHOLTZ; HALL, 2005), respectivamente, além de reforçar sua identificação e a distinção quanto aos outros pela repetição (por gradação). Um dos alvos da distinção é Enzo, que constrói uma identidade de estagiário experiente tanto no estágio (ao dizer que já tinha estagiado em uma escola estadual) como na docência (fato já sabido por Elis, que é confirmado para mim na linha 99). Pode-se também considerar que ela se diferencia de mim (que sou representada por ela em nossa relação como professora) e talvez até dos outros estagiários (seus colegas, todos com alguma experiência na profissão docente).

Em segundo lugar, Elis não destaca apenas sua falta de experiência em relação a nós, mas também parece se referir à inexperiência na prática com o IFE, exemplificada por ela pela menção à escola técnica (distinta do que ela chama de 
'escola comum') e à produção de material. Do que foi dito, depreende-se que o estágio, a docência e o IFE fazem parte do tudo (com efeito reforçado novamente pela repetição quatro vezes), que ela avalia como diferente, que é muito novo, que está fazendo pela primeira vez. Não só a repetição do 'tudo', que por si só já é graduado, mas também a ênfase dada na primeira menção à essa palavra (representada pela fonte em caixa alta) é aqui um recurso de gradação, constituinte da avaliação de Elis e parte da construção de suas identidades.

Por apreciação, ela avalia o 'tudo' (suas primeiras vivências no estágio, na docência e no IFE) como novo e diferente nas linhas 101 e 105, mas não esquece de se avaliar como participante do estágio, por julgamento, ao dizer tudo eu estou fazendo isso aqui pela primeira vez. Pode-se compreender que essas avaliações remetem à inexperiência (ao novo, à primeira vez), mas que ela se identifica como estagiária que está 'participando', fazendo isso (que entendo como 'estagiando e praticando a docência e, mais especificamente, o IFE') aqui, 'no estágio'. Assim, a partir da premissa de que suas escolhas lexicogramaticais e semânticas constroem identidades (e que essas, ao mesmo tempo, são responsáveis por essas escolhas), concluo que toda a fala de Elis no Excerto 5 da Conversa 1 a (re)constrói como estagiária inexperiente no estágio, na docência e no IFE. Na sequência a esse excerto, conversamos sobre o acolhimento na escola de estágio, primeiramente sobre a dificuldade de Enzo e Elis para conseguir vagas para fazer português no IFRJ, para logo depois Elis se (re)construir em suas avaliações do estágio de inglês.

Conversa 1 - Excerto 6 - 0 acolhimento na escola de estágio

\begin{tabular}{|r|l|l|l|}
\hline 107 & Carla & você está fazendo português aqui também, não? \\
\hline 108 & Elis & não... só estou fazendo inglês \\
\hline 109 & Carla & e português você vai fazer depois \\
\hline 110 & Elis & pretendo... pretendo não.. . tem que fazer ( (Elis e Enzo riem) ) \\
\hline 111 & Enzo & é...tem que fazer ( (Elis e Enzo riem) ) ... tem minha vaga lá... só \\
\hline 112 & & esqueceram de avisar ao coordenador ( (Elis e Enzo rindo muito) ) \\
\hline 113 & Carla & porque pra mim vocês estavam tentando [fazer em outra escola] \\
\hline 114 & Elis & [a gente] \\
\hline 115 & Carla & então tem que conversar com o professor daqui depois \\
\hline 116 & Elis & a gente tá tentando mas não tá conseguindo não (.) \\
\hline 117 & & mas então o: o estágio aqui eu estou achando que está sendo bom \\
\hline 118 & & $\ldots$ assim (.) você e a Maria são bem simpá:ticas... são... \\
\hline 119 & & as turmas são recepti :vas né... [os alunos eles] \\
\hline 120 & Carla & [é eles são] \\
\hline 121 & Elis & é ... os alunos eles FA:lam com você assim... eles não ficam (.) \\
\hline 122 & & distan:tes... então é bom \\
\hline
\end{tabular}

No excerto 6 da Conversa 1, Elis avalia sua reação ao estágio por meio de apreciação positiva (como bom, nas linhas 117 e 122), mas ela é apresentada 
como diretamente vinculada ao tratamento recebido pelos alunos e professores, avaliados por julgamento positivo (dando grande relevância ao nosso comportamento, mais especificamente à receptividade quanto a ela). Essas escolhas sugerem que Elis se constrói discursivamente a partir de suas crenças e emoções de (in) segurança e se mostra como vulnerável, em busca de aceitação e acolhimento por estar em uma posição de estagiária novata (cf. princípio de posicionalidade).

Ao voltarmos às respostas das questões iniciais e à Conversa 4, também é possível inferir que Elis atribui grande importância à visão dos outros quanto a si mesma, que é uma perspectiva recorrente em suas (re)construções identitárias nos dados e será retomada com maior detalhamento mais adiante na análise. No entanto, aqui chamo a atenção para esse aspecto nas linhas 10 a 11 das respostas, onde reconhecemos a identidade-crença-emoção da estagiária como auxiliadora dos alunos e receosa quanto à receptividade desses e dos docentes, com os quais ela 'esperava ter um bom convívio', o que é recuperado na Conversa 4 para reflexão: aí eu achava que eu ia ter muito contato com os alunos e não tanto com vocês ... e eu acho que no final das contas eu acabei me envolvendo mais com vocês do que com os alunos.

Por um lado, por já estar próxima ao final da caminhada do estágio quando aconteceu a Conversa 4, Elis questiona e reformula sua crença anterior (ambas construídas por afeto) por 'achar' (no sentido de sentir, acreditar e se entender em um novo contexto) que o envolvimento com os professores superou suas expectativas, talvez por já se perceber cada vez mais como membro da comunidade de prática, como pode ser inferido em outros excertos da Conversa 4. Por outro lado, parece que essa reflexão serve, ao mesmo tempo, como uma introdução à sua perspectiva quanto à posição de fragilidade dos estagiários, o que discuto juntamente com o próximo excerto da mesma conversa:

Conversa 4 - Excerto 2 - "Onde que a gente se encaixa aqui?"

\begin{tabular}{|l|l|l|}
\hline 11 & Elis & e assim... eu acho que no sábado eu até consegui um pouquinho mais \\
\hline 12 & & mas na quinta feira eu não consegui me enturmar tanto \\
\hline 13 & & com a turma ... eu queria MAIS... \\
\hline 14 & Carla & hurrum \\
\hline 15 & Elis & [principalmente] a de meio-ambiente... [a última] \\
\hline 16 & Fábio & [eu também] \\
\hline 17 & Elis & eles são muito legais (.) então... mas eu eu não sei assim de quais \\
\hline 18 & & formas ... porque a gente fica meio sem jeito de se meter \\
\hline 19 & Lara & é mesmo \\
\hline 20 & Elis & até também pra não tirar ...espaço... o espaço de vocês como \\
\hline 21 & & professores (.) ficar... "a: ... eu que sou a professora agora"... \\
\hline
\end{tabular}




\begin{tabular}{|l|l|l|}
\hline 22 & & não vou fazer isso né? então... a gente fica ali num... parece que a \\
\hline 23 & & gente fica meio sem lugar eu acho \\
\hline 24 & & a gente não é aluno e também não é professor... entã: o \\
\hline 25 & Fábio & não tem lugar \\
\hline 26 & Elis & onde que a gente se encaixa aqui? \\
\hline 28 & Hugo & acho que assim, no início também é uma coisa que eu não sei \\
\hline 30 & & porque ... o que eu percebi dentro do estágio \\
\hline 31 & & é que vocês fazem sim um esforço pra trazer a gente pra a sala \\
\hline 32 & & de aula ... pra fazer a gente participar mas eu acho que \\
\hline 33 & & no início a gente se sente um pouco assim... INCAPAZ \\
\hline 34 & Lara & [é: ] \\
\hline 35 & Elis & [si :m] \\
\hline 36 & Hugo & eu me senti um pouco incapaz assim de realmente assim é \\
\hline 37 & & porque eu cheguei aqui com uma visão bem geral que coloquei \\
\hline 38 & & das respostas do esp ... peguei inglês para fins específicos \\
\hline 39 & & e desenvolvi numa frase... foi uma coisa bem geral mesmo... tava \\
\hline 40 & & com o entusiasmo de aprender realmente assim como que era o esp \\
\hline 41 & & eu lembro que não sabia... coloquei aqui como o professor utiliza \\
\hline 42 & & o material né? ( (todos riem) ) minha expectativa pra material aí \\
\hline 43 & & eu coloquei livro didático e material extra ( (todos rindo muito) ) \\
\hline 44 & & ou seja eu achava que tinha livro didático né? \\
\hline 45 & & então eu não tinha noção ainda das coisas \\
\hline
\end{tabular}

As respostas para as questões iniciais, o Excerto 6 da Conversa 1 e os Excertos 1 e 2 da Conversa 4 suscitam o entendimento de que existe uma busca por aceitação e pertencimento no estágio por parte dos estagiários (não só de Elis, mas também de Lara, Fábio e Hugo seus colegas licenciandos) atravessada por um forte sentimento de insegurança. Essa leitura é proporcionada primeiramente quando Elis menciona em suas respostas seu desejo em se engajar no estágio a partir das relações interpessoais 'tendo bom convívio com professores e alunos e auxiliando' os últimos (que também traz a crença/emoção de subserviência e insegurança na construção de sua identidade como auxiliadora dos alunos $e$ receosa quanto à receptividade desses e dos docentes). Percebemos que, mesmo ao concluir que houve um maior engajamento com os professores na Conversa 4, esse desejo de se conectar aos alunos continua presente, talvez a partir da crença de que essa é uma das funções dos estagiários ou até mesmo dos docentes (também mencionada na análise da Conversa 1 - Excerto 3).

No excerto 2 da Conversa 4, tal desejo, que emerge por afeto, é acentuado (com gradação) nas linhas 11 a 13 por Elis (em eu acho que no sábado eu até consegui um pouquinho mais, mas na quinta feira eu não consegui me enturmar tanto... eu queria MAIS) e corroborado por Fabio na linha 16. A partir daí, percebemos como os três licenciandos parecem estar em alinhamento quanto às suas avaliações sobre sua posição (cf. princípio de posicionalidade) naquele contexto, construindo e sendo construídas por suas 
identidades-crenças-emoções como estagiários. Notamos que Elis passa a se referir a si mesma como parte desse grupo por 'a gente', assumindo essa identidade coletiva por adequação, para expressar como os estagiários se sentiam/entendiam, e, ao mesmo tempo, por distinção (cf. princípio de relacionalidade) aos alunos (referidos como 'eles', na linha 17, por exemplo) e aos professores regentes (que são 'vocês', na linha 20).

Assim, Elis fala por seu grupo e tenta explicar o porquê da falta de maior proximidade com os alunos, expondo sua situação angustiante de estar/ acreditar/se sentir 'sem lugar', ou como mencionado por Miller (2013) e Valsechi (2016), em um entrelugar, na posição de 'estagiários', indexicalizada por Elis como alguém que 'não é aluno e também não é professor' na linha 24 (cf. princípios de posicionalidade e de indexicalidade). Portanto, parece que emergem identidades-crenças-emoções de Elis de estagiária insegura, 'de fora'l uma intrusa/ incômoda (o que pode ser depreendido, por exemplo, em não sei de quais formas e a gente fica sem jeito de se meter e por não ter onde 'se encaixar', linhas 17, 18 e 26), que são discursivamente coconstruídas por insegurança (dentro de afeto, das linhas 18 a 35).

O questionamento de Elis falando por todos (que culmina em sua proposição onde que a gente se encaixa aqui? na linha 26 realizada por afeto evocado de insegurança) é complementado pela fala de Hugo, que reforça a coconstrução dos estagiários como inseguros (por se 'sentirem incapazes', o que emerge também por afeto, linhas 33 a 35). Assim, vemos que, além de se entenderem, sentirem e acreditarem ser como 'intrusos', eles trazem a identidades-crençasemoções de incapacidade no início do estágio, que pode ter sido gerada pelo desconhecimento do IFE. Essas construções conjuntas sugerem uma situação muito inquietante que prejudica a qualidade de vida no estágio em nossa comunidade de prática e acredito que esses temas (especialmente as identidadescrenças-emoções de intrusão, não pertencimento e de incapacidade) devem ser esmiuçados durante o estágio. Em outras palavras, creio ser necessária a pesquisa conjunta dos nossos processos de aprendizagem (nos quais incluo meu processo e dos estagiários como professores e o meu como regente), que a meu ver, perpassam questões como essas. A insegurança possivelmente gerada pelo desconhecimento do IFE também parece evidenciar a necessidade de preparação inicial dos estagiários, na universidade, para ensinar essa disciplina.

É possível interpretar também que a questão do 'espaço do estagiário' como exíguo e restrito parece ser algo culturalmente aceito em nossa sociedade, o que 
é indexicalizado no texto de Elis nas linhas 20 a 24 - até também pra não tirar ... espaço... o espaço de vocês como professores ... ficar... "a: ... eu que sou a professora agora"... não vou fazer isso né?. Nessas orações, por meio de julgamento de sanção social, Elis se constrói como não-professora (também por distinção a nós professores, como já mencionado) e estagiária ética (que sabe muito bem 'o seu lugar', que não tenta 'se meter', 'ser professora quando não é' ou 'tirar o espaço' do outro). Percebe-se ainda que, apesar da tentativa de criação de empatia com suas interlocutoras (eu e Maria) pelo uso de julgamento positivo (em vocês fazem sim um esforço pra trazer a gente pra a sala de aula, linhas 31 e 32), a escolha de Hugo por 'esforço' também salienta a dificuldade para se atenuar ou desfazer o que pode ser uma relação de poder social e culturalmente estabelecida que aparece na crença de que professores agem (falam, conduzem as aulas, etc.) e os estagiários são apassivados (como citado na linha 31, que precisam 'ser trazidos para sala de aula', por exemplo).

Esse entendimento pode ser inferido também da fala de Elis ${ }^{40}$ no Excerto 7 da Conversa 1, onde ela avalia positivamente o fato de os professores 'darem espaço' para os estagiários (em bom que vocês dão esse espaço pra gente pra gente dar sugestõ:es também... pra falar lá na frente e tal, linhas 146 e 147). A questão do espaço é, portanto, muito relevante para a construção dos estagiários: eles mencionam que ele é dos regentes (em o espaço de vocês como professores, na Conversa 4, linha 20), mas esses professores têm o poder de 'dar espaço' aos estagiários (Conversa 1, linha 146). De tudo o que foi dito neste parágrafo, é possível concluir que das realizações analisadas parece emergir a identidade-crença de estagiários passivos, esperando a intervenção dos professores regentes para se integrarem às aulas. Talvez sejam realmente necessárias mais intervenções, como conversas francas para entendermos juntos o que pensamos e sentimos (sobre espaços, colaboração, nossas relações interpessoais etc.), como parece ilustrar o Excerto 3 da Conversa 4, aqui transcrita:

Conversa 4 - Excerto 3 - "Eles acabam virando mais pra gente"

\begin{tabular}{|l|l|l|l|}
\hline 1 & Carla & uma coisa que eu queria fazer era chamar os estagiários \\
\hline 2 & & de lá de trás (.) isso me incomoda um pouco .. . o que vocês \\
\hline 3 & & acham assim? vocês acham que isso atrapalharia vocês? \\
\hline 4 & Elis & eu acho que, dependendo da turma fica melhor >porque eu acho \\
\hline
\end{tabular}

\footnotetext{
40 Esse excerto será analisado mais detalhadamente na seção 6.1.2.
} 


\begin{tabular}{|r|l|l|}
\hline 5 & & que depende da turma< naquela turma por exemplo \\
\hline 6 & & de quinta-feira a primeira que é muito cheia \\
\hline 7 & & a gente ficar ali atrás é muito bom porque eu acho que \\
\hline 8 & & os alunos tem muito aluno inseguro ali atrás, entendeu? \\
\hline 9 & & "a: não sei inglês ... assim" \\
\hline 10 & & e aí eles acabam virando mais pra gente \\
\hline 11 & & que é estagiário ... porque: ficam com medo \\
\hline 12 & & eu tô falando no sentido de que eu acho que \\
\hline 13 & & a gente sentar ali atrás pode ajudar... é estratégico \\
\hline 14 & & sábado por exemplo... isso já não é bom ... é mais fácil \\
\hline 15 & & fazer uma roda e ficar no meio deles mas em uma turma grande \\
\hline 16 & & a bml31 tem dezoito alunos naquela sala alí né? \\
\hline 17 & & aí fica assim né ... fica be:m \\
\hline 18 & Carla & é fica bem apertado ... eu não tinha pensado nisso não porque eu \\
\hline 19 & & ficava assim "gente... será que eu posso pedir pra vir aqui \\
\hline 20 & & pra frente?" talvez se vocês não sentarem JuNtos \\
\hline 21 & Elis & é bom espalhar que fica melhor \\
\hline 22 & Carla & [isso espalhar um pouco né?] \\
\hline 23 & Maria & [é espalhar... eu também não gostava] de todos juntos não \\
\hline 24 & Carla & não me incomodo ( (inaudível) ) \\
\hline 25 & Maria & não... porque tinha dia que tinha muitos estagiários \\
\hline 26 & & se não espalhar fica uma turma de estagiários e outra de alunos \\
\hline
\end{tabular}

Nesse excerto, nota-se que Elis se constrói em discordância parcial quanto à minha opinião, mas apresenta sua proposição como uma entre outras possibilidades (por engajamento de expansão dialógica - entretenimento) em eu acho que, dependendo da turma fica melhor, que se refere aos estagiários se sentarem atrás, na linha 8. Ela também avalia a localização dos estagiários por apreciação (por exemplo em fica melhor, é muito bom, é estratégico nas linhas 4, 7 e 13) e pondera sobre as diferentes situações nas salas (como o espaço físico, o número de alunos e como eles se sentem) para expor seu ponto de vista. Nessas escolhas, percebe-se um posicionamento como estagiária engenhosa, atenta e conhecedora do contexto, pronta para colaborar em nossa comunidade.

Além disso, Elis parece buscar empatia ao avaliar alguns alunos por recursos de julgamento quanto à tenacidade deles (em tem muito aluno inseguro e ficam com medo, linhas 8 e 11), trazendo para seus interlocutores sua visão desses alunos como 'necessitados da ajuda dos estagiários' e, nesse interim, emerge para ela (e seus colegas) a identidade de auxiliadora dos alunos. Ao mesmo tempo, pode-se interpretar que Elis se reformula nessas avaliações (pois, naquela situação, parece fluir uma nuance menos apassivada de suas identidades) e assume um posicionamento de praticante de IFE membro de nossa comunidade de prática (linhas 4 a 17).

A partir das análises das interações transcritas nos excertos 2 e 3 da Conversa 4, pude começar a reavaliar algumas de minhas crenças e, apesar de o 
tema infelizmente não ter sido muito desenvolvido naquele momento, nossa conversa lançou luz sobre a inquietação sentida tanto pelos professores regentes quanto pelos estagiários quanto aos espaços (não só físicos) das pessoas no estágio. Sendo assim, acredito que essa interação pode ser traduzida como questões (como, por exemplo, sobre como nos sentimos e no que acreditamos quanto aos 'lugares que ocupamos' no estágio e como podemos melhorar a qualidade de vida nesse ambiente) para discussão em outros momentos.

$\mathrm{Na}$ conversa sobre a regência de Elis, também surgiram questões importantes para nossas reformulações pessoais e profissionais. Nessa interação, estávamos presentes eu, Flávia (a professora de Prática de Ensino), Elis e Fábio e ela aconteceu depois nos últimos tempos de sábado, após a apresentação das aulas dos dois licenciandos. Assim que eu e Flávia fechamos as notas das regências, fui chamar os dois estagiários no corredor, onde eles estavam conversando com alguns alunos, que os acompanharam até a nossa porta e interagiram comigo e Flávia também. Apesar de o grupo estar dando boas risadas, era perceptível a tensão dos dois licenciandos que estavam sendo avaliados e isso aparece também na linguagem, como pode ser visto a seguir.

Conversa 5 - Excerto 1 - “Eu achei que eles gostaram e eu achei que eu consegui passar”
\begin{tabular}{r|l|l|l|}
\hline 1 & Carla & demorou muito? \\
\hline 2 & Fábio & puxa... tamos tensos... \\
\hline 3 & Carla & ( (todos rindo) ) podem entrar (.) eu vou continuar gravando tá? como eu \\
\hline 4 & & falei para vocês antes... tô vendo que tão com o olho assim... que foi? \\
\hline 5 & Elis & ( (rindo) ) a gente >ficou com medo< \\
\hline 6 & Flávia & mas por quê? \\
\hline 7 & Carla & ( (nós nos sentamos em círculo) ) deixa eu virar mais um pouco \\
\hline 8 & Carla & é então é: vamos começar com a elis... pode ser? o que vocês preferem? \\
\hline 9 & Elis & [pode ser] \\
\hline 10 & Fábio & [pode ser] \\
\hline 11 & Carla & ou pelo último que tá mais fresco na mente? \\
\hline 12 & Flávia & acho que pode começar por ela \\
\hline 13 & Carla & é? então elis ... o que você achou da sua aula? \\
\hline 14 & Elis & eu achei que foi boa assim eu achei que eles gostaram e: eu achei que \\
\hline 15 & & eu consegui passar o: : >passar não< (4) não sei o verbo que eu \\
\hline 16 & & uso ( (rindo) )...que verbo eu uso? >acho que ficou claro< eles acho que \\
\hline 17 & & já sabiam (.) o que que é fitoterapia alopatia homeopatia e tal... \\
\hline 18 & & achei que a discussão no final que foi bem (.) foi boa... teve alguns \\
\hline 19 & & erros ali na hora que eu esqueci de distribuir o texto os textos pra \\
\hline 20 & & todo mundo ficou um pouco confuso ali na hora... é: também na hora do \\
\hline 21 & & exercício... . no texto da marijuana< eu esqueci de trocar a ordem da \\
\hline 22 & & das informações no texto >mas acho até que foi<... Bom assim >eles \\
\hline 23 & & acharem que tinha pegadinha< aí ficaram meio assim ( (rindo) ) \\
\hline 24 & Carla & é: \\
\hline
\end{tabular}

Primeiramente, depreende-se um senso de "we-ness", como mencionado por Snow (2001), em proposições como tamos tensos e a gente >ficou com medo<, nas linhas 2 e 5, que parecem mostrar que é conjunta a identidade-crença- 
emoção de Elis e Fábio como estagiários e alunos inseguros por estarem sendo avaliados, que emerge por afeto inscrito. Ao referir-se a si mesma individualmente, Elis parece manter o posicionamento (cf. princípio de posicionalidade, proposto por BUCHOLTZ e HALL, 2005) de estagiária e aluna em avaliação, ao passo que eu e Flávia somos vistas como suas professoras. Essa construção se dá em várias instâncias do Excerto 1 da Conversa 5, mas torna-se evidente das linhas 14 a 16 (em eu achei que eu consegui passar o:: >passar não< não sei o verbo que eu uso((rindo)) ...que verbo eu uso?. Nessa ocasião, depreende-se a inquietação de Elis quando ela se autocorrige, ri, fica em silêncio pensando (linha 15), pede ajuda a mim e à Flávia para reformular o que queria dizer e nega a escolha pelo processo 'passar', que parece não estar de acordo com as crenças de suas professoras (dentre as quais de que os conhecimentos em sala de aula não são 'transmitidos', mas compartilhados e de que docentes e discentes aprendem nessa interação), que parecem ser crenças pelas quais ela também quer ser reconhecida.

Elis utiliza todas as oportunidades para se justificar pelo que pode ser considerado negativo. Para tanto, ela intercala avaliações sobre aspectos da aula por apreciação positiva (como em achei que a aula foi boa, >acho que ficou claro<e achei que a discussão no final que foi bem (.) foi boa), sobre os alunos por julgamento positivo (em achei que eles gostaram ${ }^{41}$ e eles acho que já sabiam, provavelmente usados por Elis para ilustrar para seus ouvintes como os alunos estavam envolvidos) e faz uso de alguns recursos avaliativos negativos, que são logo mostrados por uma visada mais positiva (como quando Elis se avalia por julgamento negativo em eu esqueci de trocar, mas logo transforma essa perspectiva quando traz uma apreciação positiva em mas acho até que foi<... BOM assim eles acharem que tinha pegadinha). Desse modo, a negatividade fica mais diluída e Elis se mostra sob uma perspectiva positiva tanto quanto à aula em si, quanto pelo seu posicionamento crítico-reflexivo, que é esperado por suas interlocutoras, o que foi conversado com Elis antes da regência e está implícito na pergunta de Flávia na primeira linha do próximo excerto ${ }^{42}$.

\footnotetext{
41 Já que a avaliação parte de Elis (e não dos discentes), talvez com vistas a mostrar para seus interlocutores como ela entende a reação dos alunos, eu a considero como julgamento, seguindo as recomendações de Thompson (2014b), conforme explicado na p.75.

$42 \mathrm{~A}$ numeração das linhas do excerto foi reiniciada porque ele ocorre minutos depois do que foi transcrito no excerto anterior. Assim, fica mais claro que os excertos não são subsequentes. Isso também aconteceu com outras partes desta conversa, bem como nas Conversas 3 e 4.
} 
Conversa 5 - Excerto 2 - "Tô com medo de me dar uma nota mais alta do que eu mereço"

\begin{tabular}{|r|l|l|}
\hline 1 & Flávia & quanto que você se daria? \\
\hline 2 & Elis & a: >tô com medo de me dar uma nota mais alta do que eu mereço< (9) \\
\hline 3 & Fabio & 'foi muito bom elis ${ }^{\circ}$ \\
\hline 4 & Elis & não sei... ai ai ai \\
\hline 5 & & eu acho que não seria dez... mas acho que abaixo dos nove também \\
\hline 6 & & num... não seria... alguma coisa por aí (6) \\
\hline 7 & & falando sobre essa aula ou sobre o estágio todo? \\
\hline 8 & Carla & não... só sobre a aula (8) \\
\hline 9 & Flávia & bom... eu queria [fazer uns comentários] \\
\hline 10 & Elis & \multicolumn{1}{c}{ [A QUESTÃO] do tempo... não DEU muito pra eu seguir } \\
\hline 11 & & exatamente o que tava aí porque >não dá para a gente prever como eles \\
\hline 12 & & vão reagir e o primeiro passo demorou mais tempo do que eu pensei que \\
\hline 13 & & fosse demorar< \\
\hline 14 & Flávia & então ... posso pegar esse gancho? \\
\hline 15 & Elis & hurrum \\
\end{tabular}

No que concerne a nota, Elis usa marcas de afeto - insegurança (em a: >tô com medo de me dar uma nota mais alta do que eu mereço<, linha 2), que a constroem como estagiária receosa e, ao mesmo tempo, humilde. Essas identidades também emergem em sua constante utilização (doze vezes somente nesse excerto) de um recurso de engajamento de expansão dialógica realizado pelas modalizações 'acho' e 'achei', que sugerem que Elis escolhe não se impor, reconhecendo que seus interlocutores podem ter pontos de vista diferentes dos que ela apresenta em suas proposições.

É possível entender que Elis se esforça para listar prós e contras da sua regência, chegando até a interromper Flávia para citar mais um ponto na linha 10, mesmo depois de o assunto em foco ter sido mudado para a nota que ela se daria (em A QUESTÃO do tempo... não DEU muito pra eu seguir exatamente o que tava aí porque >não dá para a gente prever como eles vão reagir e o primeiro passo demorou mais tempo do que eu pensei que fosse demorar $<$ ). Parece que ela tenta se adiantar para dar explicações sobre o que poderia ser questionado por nós (professoras que estavam avaliando a regência) antes que o fizéssemos, o que também a constrói, concomitantemente (seguindo o princípio de parcialidade), como aluna insegura. Ao mesmo tempo, talvez esse seu posicionamento se baseie na crença de que sua autoavaliação deveria ser ampla, por isso deveria se esforçar para comentar diferentes tópicos, apontando também os pontos negativos, o que a constrói como estagiária observadora e crítico-reflexiva, identidade que também emerge de suas escolhas em sua segunda entrada em diário, como reproduzido no Excerto 2, que se segue. 
Diário sobre a Regência- Excerto 2

\begin{tabular}{|l|l|}
\hline 193 & Uma coisa que valorizo muito é a auto avaliação \\
\hline 194 & e a autorreflexão em geral. É importante que o aluno reflita \\
\hline 195 & sobre seu próprio desempenho, levando em conta as atitudes positivas \\
\hline 196 & que teve e também as que pode melhorar no futuro. \\
\hline 197 & Apesar de não fazer parte da avaliação oficial, achei muito válido \\
\hline 198 & que as professoras tenham me perguntado que nota me daria. \\
\hline 199 & Também considero positivo termos mais de uma professora nos avaliando, \\
\hline 200 & para que assim a nota não seja centralizada em uma única perspectiva. \\
\hline
\end{tabular}

No Excerto 2 do Diário sobre a Regência, Elis se encaminha como aluna, também em distinção (cf. princípio de relacionalidade) às professoras que são citadas na linha 198. A partir de escolhas avaliativas muito positivas, dentro do domínio da apreciação, sobre a avaliação de sua regência, além de se mostrar observadora e crítico-reflexiva, podemos interpretar que Elis se constrói como uma professora 'em processo', ciente da possibilidade de aprendizado em todas as oportunidades, como também uma pessoa ética, mostrando uma preocupação com a consideração de múltiplas perspectivas. Essas construções se tornam muito pertinentes em sua caminhada como professora visto que as avaliações são atividades constantes no fazer docente.

Voltando à Conversa 5 , outra vez, chamo a atenção para o apoio do outro na construção identitária dos estagiários: Fábio dá seu suporte a Elis (em foi muito bom elis), encorajando-a a responder. Inicialmente ela parece temerosa (na linha 4, em onão sei... ai ai aiº, também em voz baixa, como em retorno ao tom usado por Fábio) e parece haver uma coconstrução de Elis como estagiária insegura. Entretanto, logo em seguida, ela expande sua fala em uma apreciação positiva sobre a sua aula (em eu acho que não seria dez... mas acho que abaixo dos nove também num... não seria... alguma coisa por aí), da qual se infere a emergência da identidade de pessoa ponderada e que se valoriza. Assim, por um lado, quando o alvo da avaliação é ela mesma, ela usa afeto, insegurança; por outro, ao avaliar a aula, que é foco de apreciação com engajamento de contração dialógica (restringindo a sua nota 'de nove a dez', o que a classifica como excelente), ela mostra uma visão muito positiva de seu feito (apesar do abrandamento da gradação pelas modalizações com "eu acho"), do que pode se inferir um posicionamento muito mais assertivo, mostrando menos insegurança. Dessas interpretações, vislumbramos diferentes facetas de Elis, que, à primeira vista, podem parecer se contrapor, mas que se complementam, formando um complexo intricado que são nossas identidades (cf. princípio de parcialidade). 
É importante mencionar novamente que a ficha de avaliação usada por nós, professores avaliadores, é disponibilizada para os estagiários no início do estágio e são eles que trazem as cópias que nós preenchemos e nas quais fechamos a nota. Portanto, os licenciandos sabem o que está previsto para ser discutido quanto ao processo de estágio, o que inclui o desenvolvimento desde o início do mesmo. Provavelmente, essa foi a razão da pergunta de Elis na linha 7 (falando sobre essa aula ou sobre o estágio todo?), o que pode também estar ligado à crença de que sua autoavaliação deveria ser abrangente, como já mencionado.

Outros tópicos aventados por Elis foram a questão do tempo gasto e a reação dos alunos nas atividades, que são apresentados de forma interconectada e avaliados por apreciação, ao invés de ela usar julgamento com foco em sua capacidade (em não deu muito pra seguir exatamente não dá para a gente prever como eles vão reagir. Essas escolhas orientam os interlocutores a lançarem um olhar favorável quanto à atuação da estagiária, justificando, de antemão, qualquer crítica que pudesse ser feita sobre os tópicos a partir de uma afirmação categórica (em 'não deu' e 'não dá'), não abrindo margem para que questionem o que está sendo exposto (por contração dialógica - engajamento).

A partir daí, Elis se coconstrói como estagiária atenta às observações e conselhos de sua professora de Prática de Ensino (apenas rindo e assentindo pelos próximos quatro minutos e Flávia se posiciona como avaliadora, apontando aspectos a serem melhorados por sua estagiária avaliada, como o uso do tom de voz baixo e a falta de detalhamento do planejamento da licencianda. Por vários minutos, Elis apenas concorda com sua professora (com hurrum), até o excerto 3 , transcrito em seguida.

Conversa $\mathbf{5}$ - Excerto $\mathbf{3}$ - “Eu vou acabar me enrolando mais”
\begin{tabular}{r|l|l|}
\hline 1 & Elis & eu ia se-parar mais mas depois eu pensei pra mim "eu vou acabar me \\
\hline 2 & & enrolando mais" eu não sei \\
\hline 3 & Flávia & eu acho que [podia ajudar] \\
\hline 4 & Elis & [porque como eu disse pra você o objetivo seria o mesmo] \\
\hline 5 & Flávia & pois é... eu não sei ... não sei mesmo porque... você tá lidando com \\
\hline 6 & & vídeo e você tá lidando com texto... são dois tipos de materiais \\
\hline 7 & & diferentes ... vamos botar nos termos que a gente vê na nossa aula \\
\hline 8 & & são dois textos situados sociohistoricamente e isso faltou aqui tá \\
\hline 9 & & $\ldots$ que fazem circular ideologias ... que ideologias são essas... você \\
\hline 10 & & vamo botar isso aí... e acho que você subestimou o quão interessante \\
\hline 11 & & poderia ser a temática \\
\hline
\end{tabular}


Nesse excerto, Elis tenta justificar sua escolha de tratar o vídeo e o texto escrito em um só bloco por meio de julgamento de sua abordagem quanto à regência (em eu ia se-parar mais mas depois eu pensei pra mim "eu vou acabar me enrolando mais" eu não sei) e apreciação do objetivo (em seria o mesmo). Essas avaliações parecem ter sido usadas na tentativa de Elis se mostrar como elaboradora de aula, que refletiu sobre os aspectos discutidos e decidiu fazer o que seria melhor naquele contexto, mas que se sentia insegura com as ferramentas de trabalho. Assim como Marcelo (2009), acredito que nós professores vivemos em (des) confiança quanto à utilização de materiais, principalmente quando exigem o uso de tecnologia e de inovações pedagógicas, o que também tem influência em nossas identidades. Por isso, é de grande importância que os estagiários tenham a oportunidade de acompanhar e participar ativamente da construção de aulas ao longo do estágio para que esse tipo de inquietação, comum em nossa carreira docente, seja experienciada e discutida emtre os licenciandos e os professores regentes (e também os de Prática de Ensino).

No caso de Elis, apesar de ter ocorrido a sua participação cada vez ativa no estágio, acredito que o uso de diferentes gêneros e suportes poderia ter recebido maior atenção de todas nós professoras orientadoras (especialmente na fase anterior à aula, na qual debatemos o planejamento). Dessa forma, interpreto que os pontos mais criticados na aula de Elis por mim e por Flávia (que foram a utilização inadequada de dois gêneros discursivos, a clareza nas instruções e a forma que ela encarou o assunto para desenvolver o início da aula ${ }^{43}$ ) se relacionam diretamente com alguns dos significados de nossa comunidade de prática (conforme discutido por KIELY, 2015) que poderíamos ter desenvolvido melhor com Elis durante o estágio. De qualquer forma, a regência parece ter sido um momento de reformulação para Elis, como sugerem suas avaliações no excerto 5 da mesma conversa.

Conversa 5 - Excerto 4 - "Foi mais tranquilo do que eu pensei"

\begin{tabular}{|r|l|l|}
\hline 1 & Carla & você se saiu muito bem... você tava nervosa lá fora mas \\
\hline 2 & Elis & mas eu ... foi mais tranquilo do que eu pensei que ia ser ...assim \\
\hline 3 & & do que eu imaginava \\
\hline 4 & Carla & você tava esperando [ter mais o que] \\
\hline 5 & Elis & [assim... eu não] fiquei gagueja:ndo= \\
\hline 6 & Carla & nã: : o \\
\hline 7 & Flávia & não mesmo \\
\hline 8 & Elis & =eu não esqueci o que eu ia fala:r... é: eu até poderia ter feito \\
\hline 9 & & uma instrução melhorzinha mas assim \\
\hline
\end{tabular}

${ }^{43}$ É importante salientar que Elis conduziu um debate no final da aula e toda a organização e condução do mesmo foram muito elogiados pelas professoras. Portanto, essas observações se restringem ao uso do texto escrito (que era um artigo de divulgação científica) e ao vídeo. 


\begin{tabular}{|l|l|l|}
\hline 10 & Carla & teve coisa que você apontou quando você foi analisar a aula que eu \\
\hline 11 & & não percebi (.) você disse "eu errei não sei o quê" não vi \\
\hline 12 & & ( (todos riem) ) não chamou a atenção \\
\hline 13 & Flávia & ${ }^{\text {não...não }}$ \\
\hline 14 & Carla & talvez você tenha se preocupado com algumas coisas enquanto você tava \\
\hline 15 & & lá fora esperando pensando que talvez a gente fosse falar disso \\
\hline 16 & & a: e outra co: isa que eu não sei se e acho que a flavia concorda mas \\
\hline 17 & & não sei se ela já comentou... acho que não... é que o planejamento \\
\hline 18 & & tá ali como base pra vocês mas é a tua turma que vai dar o tom \\
\hline 19 & & na verdade ... eles vão falar coisas que não estavam planejadas né \\
\hline 20 & & como ela tava dizendo a garota falou earth né \\
\hline 21 & Fábio & é: aí você conseguiu aproveitar aquela informação e foi \\
\hline 22 & Elis & é mesmo... tomei um outro caminho \\
\hline
\end{tabular}

Nesse excerto, apesar de não usar afeto, é possível depreender que Elis tinha crenças-emoções-identidades de insegurança quanto ao momento da regência, revelando que tinha expectativas negativas (nas linhas 1, 2, 4, 7 e 8, de que talvez não fosse tranquilo, de ela pudesse gaguejar ou esquecer o que ia falar). No entanto, suas escolhas semânticas sugerem sua reconstrução a partir de uma visada positiva por apreciação da regência (em foi mais tranquilo do que eu pensei que ia ser ...assim que eu imaginava, nas linhas 1 e 2) e por julgamento de seu comportamento (nas linhas 5, 8 e 9). Portanto, considero que até mesmo ao retomar a crítica das professoras quanto as instruções da licencianda da aula (em eu até poderia ter feito uma instrução melhorzinha mas assim) a positividade está implícita e pode ser resgatada do uso dos recursos de engajamento - contraexpectativa (com o 'mas') - e pelo abrandamento da negatividade por gradação (em 'até poderia' e 'melhorzinha').

Ao mesmo tempo pode-se entender que a licencianda também se constitui na interação. A concordância de suas professoras avaliadoras (eu e Flávia) com gradação muito alta (dizendo 'não', 'não mesmo') reforçam ainda mais a coconstrução de Elis como alguém que consegue manter o controle de si. Além disso, outras perspectivas dos interactantes sobre a regência, como a apreciação positiva dos erros (que 'não chamaram a atenção') e os julgamentos positivos da atuação de Elis por mim, Elis e Fábio (com o exemplo, das linhas 20 a 22, de como ela lidou bem com um imprevisto), mostram Elis com alguém que consegue se adaptar às circunstâncias de forma adequada. Assim, das cocontruções aqui analisadas parecem emergir identidades de Elis como equilibrada e capacitada para lidar com as situações de sala de aula e, consequentemente, mais preparada em sua caminhada como professora. Com vistas a relembrar algumas das principais discussões nesta subseção, proponho o quadro 8: 
Quadro 8 - Resumo de algumas das (re)construções identitárias de Elis como estagiária DADOS

- Alguém 'de fora', não só da comunidade de prática de IFE, mas também da dinâmica do estágio em si.

- Alguém que ainda não pertence àquele contexto, mas que está ali para aprender. Assim, emergem crenças-identidades-emoções de estagiária expectante, insegura, aprendiz

\section{Respostas \\ das questões iniciais} e inexperiente na docência, no estágio e no IFE.

- Auxiliadora dos alunos e receosa quanto à receptividade desses e dos docentes

- Crenças no estágio como 'teste' de como pode ser a docência e como transição, no qual ela 'por enquanto' está/sente/se entende inexperiente.

- Insegura quanto a tornar-se professora e contando com o estágio para se decidir.

- Reformulação dessas identidades-crençasemoções, avaliadas como pertencentes ao

Conversa 4

Excerto 1 passado. Elis reavalia suas primeiras impressões de uma outra posição nos momento finais de estágio, quando se entende/sente/está sendo estagiária experiente, acolhida pelos professores e alunos, membro da comunidade de prática

Primeira
participação
de Elis
registrada em
áudio

- Estagiária insegura/ novata na comunidade de prática (bem como na participação em pesquisa), que talvez precisasse coconstruir conosco sua confiança/segurança

\section{Conversa 1}

Excerto 1

- Na interação comigo e com Enzo Elis se

"Pode falar" coconstrói como participante da pesquisa e estagiária menos experiente e insegura.

\section{Princípio de emergência}

Uso de processos mentais dentro de recursos de afeto de insegurança quanto ao estágio e à profissão docente, construindo identidades, crenças e emoções no campo da incerteza e da expectativa.

Discurso modalizado e

dialogicamente expandido.

Princípios de emergência e de posicionalidade

identidades ressignificadas de acordo com o contexto.

\section{Conversa 1}

Excerto 2

"É uma aula de inglês mesmo"
- Elis parece se construir em alinhamento com as crenças/emoções que emergem na fala de Enzo como estudante de Letras e estagiária/não instrutora.

- Crenças de que a validade do ensino de inglês está atrelada ao uso da modalidade oral, de que que os professores, apesar de sua formação, 'não ensinam' a língua quando estão na escola e de que o uso de português em sala é algo negativo.

- Desconstrução de alguns mitos, como o de que as aulas de IFE têm que ser sempre ministradas em português e de que essa abordagem é perfeita para quem não sabe inglês direito.

- A concordância parece criar solidariedade entre os estagiários.
Enzo usa engajamento (contração dialógica) para convencer Elis a falar, mas ela só ri.

Princípios de indexicalidade e posicionalidade

\section{Princípio de emergência}

Confirmação de expectativa (com "sim", "hurrum", "é uma aula de inglês mesmo") dentro de engajamento de contração dialógica - Elis ecoa proposições do colega, que usa apreciação positiva com gradação muito alta, principalmente quanto ao IFE e ao uso de modalidade oral nas aulas de inglês e julgamento negativo dos instrutores e Elis se distingue, por meio do princípio de relacionalidade, desses últimos. 


\begin{tabular}{|c|c|c|}
\hline $\begin{array}{l}\text { Conversa } 1 \\
\text { Excerto } 3\end{array}$ & $\begin{array}{l}\text { - Elis se constrói como participante da } \\
\text { interação } \\
\text { - Estagiária capaz, proativa e exemplo } \\
\text { para os alunos em "Eu não fiz curso" e "achei } \\
\text { que eu poderia mostrar pra eles que é possível } \\
\text { você aprender inglês sem ir pro curso". } \\
\text { - Elis naquele contexto também se constitui por sua } \\
\text { posição temporária como inexperiente na } \\
\text { comunidade de prática }\end{array}$ & $\begin{array}{l}\text { Elis avalia, por apreciação } \\
\text { positiva, o fato de Enzo ter } \\
\text { trazido o tema 'curso de inglês', } \\
\text { vinculando o que ela queria } \\
\text { dizer à discussão anterior. } \\
\text { Princípios de emergência e } \\
\text { de posicionalidade } \\
\text { Julgamento positivo evocado } \\
\text { de tenacidade e de } \\
\text { capacidade }\end{array}$ \\
\hline $\begin{array}{l}\text { Conversa } 1 \\
\text { Excerto } 5 \\
\text { "Pra mim é tudo } \\
\text { novo" }\end{array}$ & $\begin{array}{l}\text { - Estagiária inexperiente na docência, no } \\
\text { estágio e no IFE }\end{array}$ & $\begin{array}{l}\text { Princípios de indexicalidade } \\
\text { e de relacionalidade } \\
\text { Gradação com polaridade } \\
\text { altíssima ("TUDO muito novo") }\end{array}$ \\
\hline $\begin{array}{l}\text { Conversa } 1 \\
\text { Excerto } 6 \\
0 \text { acolhimento } \\
\text { na escola de } \\
\text { estágio }\end{array}$ & $\begin{array}{l}\text { - Elis se constrói discursivamente a partir de suas } \\
\text { crenças e emoções de (in) segurança e se mostra } \\
\text { como vulnerável, em busca de aceitação e } \\
\text { acolhimento por estar em uma posição de } \\
\text { estagiária novata. }\end{array}$ & $\begin{array}{l}\text { Apreciação (reação) positiva } \\
\text { do estágio } \\
\text { Julgamento positivo dos } \\
\text { alunos e professores regentes } \\
\text { quanto à receptividade em } \\
\text { relação a ela. }\end{array}$ \\
\hline $\begin{array}{l}\text { Conversa } 4 \\
\text { Excerto } 2 \\
\text { "Onde que a } \\
\text { gente se encaixa } \\
\text { aqui?" }\end{array}$ & $\begin{array}{l}\text { - Crença-emoção-identidade de subserviência e } \\
\text { insegurança, como auxiliadora dos alunos e } \\
\text { receosa quanto à receptividade desses e dos } \\
\text { docentes } \\
\text { - Estagiária (pertencente ao grupo dos que não } \\
\text { são alunos ou professores) insegura, 'de } \\
\text { fora'/ uma intrusa/ incômoda } \\
\text { - Elis se constrói como não-professora e } \\
\text { estagiária ética (que sabe muito bem 'o seu } \\
\text { lugar', que não tenta 'se meter', 'ser professora } \\
\text { quando não é' ou 'tirar o espaço' do outro). } \\
\text { - Identidade/crença de estagiários passivos, } \\
\text { esperando a intervenção dos professores regentes } \\
\text { para se integrarem às aulas. }\end{array}$ & $\begin{array}{c}\text { Afeto (insegurança) } \\
\text { acentuado por gradação } \\
\text { Princípios de emergência, } \\
\text { indexicalidade, } \\
\text { posicionalidade e } \\
\text { relacionalidade (por } \\
\text { adequação) } \\
\text { Julgamento (sanção social) } \\
\text { de si } \\
\text { Apreciação e Julgamento } \\
\text { positivos dos professores } \\
\text { regentes (em "bom que vocês } \\
\text { dão esse espaço pra gente") }\end{array}$ \\
\hline $\begin{array}{l}\text { Conversa } 4 \\
\text { Excerto } 3 \\
\text { "Eles acabam } \\
\text { virando mais pra } \\
\text { gente" }\end{array}$ & $\begin{array}{l}\text { - Estagiária auxiliadora dos alunos, } \\
\text { engenhosa e proativa, praticante de IFE } \\
\text { como membro de nossa comunidade de } \\
\text { prática construindo-se como conhecedora do } \\
\text { contexto, atenta às necessidades dos } \\
\text { alunos e empenhada em colaborar. }\end{array}$ & $\begin{array}{l}\text { Princípios de emergência e } \\
\text { de posicionalidade } \\
\text { Apreciação positiva da } \\
\text { localização dos estagiários e } \\
\text { uso de engajamento de } \\
\text { expansão dialógica } \\
\text { Julgamento dos alunos, } \\
\text { mostrando-os como } \\
\text { 'necessitados da ajuda dos } \\
\text { estagiários' }\end{array}$ \\
\hline $\begin{array}{l}\text { Conversa } 5 \\
\text { Excerto } 1 \\
\text { "Eu achei que } \\
\text { eles gostaram e } \\
\text { eu achei que eu } \\
\text { consegui } \\
\text { passar" }\end{array}$ & $\begin{array}{l}\text { - Coconstrução de identidade-crença-emoção de } \\
\text { Elis e Fábio como estagiários/alunos } \\
\text { avaliados e inseguros / companheiros } \\
\text { zelosos. } \\
\text { - Também individualmente, Elis parece manter o } \\
\text { posicionamento de estagiária/aluna em } \\
\text { avaliação e insegura }\end{array}$ & $\begin{array}{l}\text { Princípios de relacionalidade } \\
\text { (adequação), posicionalidade } \\
\text { emergência e parcialidade } \\
\text { Afeto inscrito de insegurança } \\
\text { Intercala avaliações sobre a } \\
\text { aula por apreciação positiva e } \\
\text { sobre os alunos por } \\
\text { julgamento positivo. Usa } \\
\text { apreciação e julgamento } \\
\text { negativos de si, que são } \\
\text { retomados de forma positiva. }\end{array}$ \\
\hline
\end{tabular}




\begin{tabular}{|c|c|c|}
\hline $\begin{array}{l}\text { Conversa } 5 \\
\text { Excerto } 2 \\
\text { "Tô com medo } \\
\text { de me dar uma } \\
\text { nota mais alta } \\
\text { do que eu } \\
\text { mereço" }\end{array}$ & $\begin{array}{l}\text { - Estagiária receosa e, ao mesmo tempo, } \\
\text { humilde. } \\
\text { - Estagiária observadora e crítico-reflexiva } \\
\text { - Pessoa ponderada e que se valoriza }\end{array}$ & $\begin{array}{l}\text { Princípios de posicionalidade } \\
\text { emergência e parcialidade } \\
\text { Afeto - insegurança } \\
\text { Engajamento - contração } \\
\text { dialógica (restringindo a sua } \\
\text { nota 'de nova a dez') }\end{array}$ \\
\hline $\begin{array}{l}\text { Diário sobre a } \\
\text { Regência } \\
\text { Excerto } 2\end{array}$ & $\begin{array}{l}\text { - Aluna } \\
\text { - Professora em processo } \\
\text { - Pessoa ética }\end{array}$ & $\begin{array}{l}\text { Princípios de emergência e } \\
\text { de relacionalidade (distinção) } \\
\text { Apreciação positiva do } \\
\text { processo de avaliação da } \\
\text { regência }\end{array}$ \\
\hline $\begin{array}{l}\text { Conversa } 5 \\
\text { Excerto } 4 \\
\text { "Eu vou acabar } \\
\text { me enrolando } \\
\text { mais" }\end{array}$ & $\begin{array}{l}\text { - Estagiária elaboradora de aula, que refletiu } \\
\text { sobre os aspectos discutidos e decidiu fazer o que } \\
\text { seria melhor naquele contexto. } \\
\text { - Crença-identidade-emoção de que existem alguns } \\
\text { temas que são intimidadores ou limitadores para o } \\
\text { trabalho do professor }\end{array}$ & $\begin{array}{l}\text { Princípios de emergência e } \\
\quad \text { de posicionalidade } \\
\text { Julgamento positivo de sua } \\
\text { abordagem quanto à regência }\end{array}$ \\
\hline $\begin{array}{l}\text { Conversa } 5 \\
\text { Excerto } 5 \\
\text { "Foi mais } \\
\text { tranquilo do que } \\
\text { eu pensei" }\end{array}$ & $\begin{array}{l}\text { - Crenças-emoções-identidades de insegurança } \\
\text { quanto ao momento da regência } \\
\text { - Antes insegura com a regência } \\
\text { - Coconstrução como estagiária equilibrada e } \\
\text { capacitada para lidar com as situações } \\
\text { de sala de aula e, consequentemente, mais } \\
\text { preparada em sua caminhada como professora. }\end{array}$ & $\begin{array}{l}\text { Princípio de emergência } \\
\text { Julgamento positivo de seu } \\
\text { próprio comportamento } \\
\text { Apreciação positiva do } \\
\text { momento da regência } \\
\text { Engajamento - } \\
\text { contraexpectativa } \\
\text { Atenuação da negatividade por } \\
\text { gradação }\end{array}$ \\
\hline
\end{tabular}

Com a organização do que foi discutido nas análises desta subseção, é possível perceber que, ao longo de sua caminhada, Elis se reconstrói por suas escolhas avaliativas como uma pessoa e estagiária cada vez menos insegura quanto à pesquisa, à docência, ao IFE e ao estágio. A seta vista no quadro tem como objetivo destacar um dos momentos em que essa reformulação de Elis fica evidente, mas ela acontece em vários outros momentos, como em sua participação gradualmente maior nas interações, em seu posicionamento como membro de nossa comunidade de prática e em sua avaliação positiva sobre si mesma em sua regência. Nesse último exemplo (na conversa sobre a regência), mesmo da posição de aluna e estagiária, quando essas identidades-crençasemoções estão imbricadas em insegurança por estar sendo avaliada por duas professoras, vemos uma Elis mais segura de si, construindo-se como capaz (por julgamento positivo) e, ao mesmo tempo, avaliando sua aula como muito boa (por apreciação e contraindo dialogicamente o discurso em "abaixo de nove também não seria").

Por outro lado, Elis também se mostra sob uma visada na qual ela expõe a posição delicada em que os licenciandos se encontram, onde não são 'nem 
alunos, nem professores'. Assim, por adequação, ela se inclui, dentro da identidade coletiva de estagiários, como um daqueles que 'não sabem muito bem onde se encaixar' no ambiente escolar, o que interfere na qualidade de vida no estágio. Entendo, como Jordão e Bührer (2013, p. 680), que Elis é, ao mesmo tempo, aluna e professora, não uma coisa ou outra e precisa ser percebida como "agente híbrido, ativo, múltiplo e coletivamente engajado no contexto social em que está atuando". Além disso, acredito que a sensação de pertencimento e a real integração ao contexto do estágio precisam ser questões de atenção e precisam do empenho e dedicação de todos nós professores em formação que integram o estágio.

Também é possível entender da análise dos dados que a crença de Elis no 'dever' do estagiário (e talvez até dos professores) de ajudar ao máximo os alunos parece se manter, ou até se acentuar, no decorrer do estágio, sugerindo que essa identidade-crença-emoção de 'auxiliadora' foi reforçada. Outro ponto que chama muito a atenção nos dados é a mudança na perspectiva de Elis quanto a se tornar docente, o que é desenvolvido mais amplamente nos excertos analisados na próxima subseção.

\subsection{2}

\section{(Re)construções de Elis como (não) futura professora}

Retornando às respostas para as questões iniciais, nas linhas 14 e 15 (em este é meu primeiro estágio na área docente e gostaria de saber se é algo que me vejo fazendo no futuro), depreende-se que a própria escolha da profissão não estava, inicialmente, definida para Elis e que ela contava com o estágio para ajudá-la a se decidir. Sob essa perspectiva, o estágio assume a função de 'teste': por meio dele ela 'examinaria' como poderia ser a docência na prática e, dependendo de sua avaliação, poderia desistir da profissão ou assumila. Seguindo esse pensamento, entende-se que a licencianda, naquela ocasião, ainda tinha dúvidas se seria professora e que não se identificava como tal, diferente de seus colegas estagiários, que se reconheciam como docentes desde a primeira participação nos dados gerados nesta pesquisa (por vezes citando cursos livres de inglês e se diferenciando dos professores de escola). 
Assim, parece que a insegurança ligada à questão da (in) experiência na construção identitária de Elis quando começou o período de pré-serviço ${ }^{44}$ está no cerne de sua identificação como (não) futura professora. Acredito também que pode haver uma conexão entre sua dúvida quanto à docência e ao que ela entende por 'experiência', isto é, que tipos de vivências e conhecimentos ela acreditava fazerem parte da construção identitária de professores, que discuto com base no Excerto 7 da Conversa 1.

\section{Conversa 1 - Excerto 7 - A questão da experiência}

\begin{tabular}{|c|c|c|}
\hline 123 & Carla & é legal ... também é assim o grupo de estagiários que a gente tem \\
\hline 124 & & aqui nesses últimos semestres também é um grupo... são muito \\
\hline 125 & & interessados .... acho muito rico pra gente (.) mesmo você dizendo \\
\hline 126 & & ( (virando para Elis)) "não tenho experiência de sala de aula... " " \\
\hline 127 & & mas você traz outras experiências ... ( (virando para Enzo)) você faz \\
\hline 128 & & outras coisas na sua sala de aula e a gente pode compartilhar ... \\
\hline 129 & & para os alunos também o fato de ter mais professores dentro da \\
\hline 130 & & sala (.) apesar de ficarem com vergonha né é: com o tempo passa \\
\hline 131 & & a ser mais normal (.) essa turma específica ... que é a bm $131 . .$. \\
\hline 132 & & eles não tiveram estagiários na sala ainda... OUtros estagiários ... \\
\hline 133 & & nos períodos passados ... mas se vocês repararem... tem algumas \\
\hline 134 & & turmas que já estão mais [acostumadas] \\
\hline 135 & Elis & {$[\mathrm{sim}]$} \\
\hline 136 & & $\left(5^{\prime \prime}\right)$ \\
\hline 137 & Carla & de qualquer forma (.) o que eu realmente sinto é que o estágio \\
\hline 138 & & em si pode ser proveitoso pra gente conversar sobre o que nós \\
\hline 139 & & estamos fazendo também... o estágio é nosso... então eu queria \\
\hline 140 & & que vocês falassem mais o que acham... dessem suas sugestõ:es \\
\hline 141 & & sobre o que a gente pode fazer pra (.) igual a gente tava \\
\hline 142 & & conversando hoje né... como está hoje (.) o material é esse... mas \\
\hline 143 & & o que a gente pode fazer pra melhorar... renovar... adequar à \\
\hline 144 & & turma (.) pra gente pensar junto .... estou oferecendo a turma .... \\
\hline 145 & & ela é de vocês também (.) as turmas são nossas ... o que vamos \\
\hline 146 & & fazer JUNtos com elas? (.) as turmas da Maria também no sábado \\
\hline 147 & Elis & eu acho bom que vocês dão esse espaço pra gente pra gente \\
\hline 148 & & dar sugestõ:es também... pra falar lá na frente e tal ... pra \\
\hline 149 & & que não tenho experiência é: : : : \\
\hline 150 & Carla & mas daqui a pouco você está tirando isso de letra \\
\hline 151 & Enzo & está mesmo... a minha primeira aula foi assim ó... \\
\hline 152 & & ( (Enzo se treme todo e nós três rimos) ) estou falando sério... \\
\hline 153 & & ( (rindo)) minha primeira aula foi terrível terrível terrível \\
\hline 154 & Elis & é um alívio que... quando eu chegar em uma esco:la eu já vou ter \\
\hline 155 & & essa experiência (.) e como eu falei na outra aula eu espero \\
\hline 156 & & conseguir dar aula assim numa escola assim... em uma escola \\
\hline 157 & & técnica (.) eu gostei mais do que ficar falando sobre gramática (.) \\
\hline 158 & & não sou muito fã de gramática \\
\hline
\end{tabular}

No excerto 7 da Conversa 1, acompanhamos uma das minhas tentativas de encorajar Elis e Enzo a se engajarem mais em nossa comunidade de prática. Para tanto, tento desenvolver minha ideia a partir da fala de Elis no excerto 6 (analisado

\footnotetext{
${ }^{44}$ Como foi explicado na seção 6.1.1, no contexto do início de estágio, Elis se constrói como aprendiz e inexperiente na docência, no estágio e no IFE e suas identidades emergem de forma imbricada às suas crenças e emoções especialmente a partir de afeto de insegurança.
} 
na seção 6.1.1), em que ela elogia o acolhimento pelos alunos do instituto. Expresso minha opinião sobre a recepção dos estagiários no instituto como algo positivo para todos nós e toco no assunto da experiência, expondo minha crença de que eles (Enzo e Elis) podem não conhecer muito sobre o contexto específico de nossa comunidade de prática, mas existem muitas outras experiências que eles trazem para compartilhar conosco (com os outros estagiários, professores e alunos do instituto). Chamo a atenção para o fato que há uma certa demora, marcada na linha 135, para Elis e Enzo tomarem o turno (talvez por precisarem de um tempo de reflexão para externar seus pontos de vista) e minha prontidão para quebrar o silêncio. Essa dinâmica nos posicionamentos interacionais pode sugerir a coconstrução de identidades de professora regente para mim e de estagiários/alunos para Elis e Enzo ou até de participante/pesquisadora para a primeira e participantes/ estagiários para os últimos por meio dos princípios de posicionalidade e indexicalidade (BUCHOLTZ; HALL, 2005).

Seguindo meu turno longo, Elis refere-se ao meu convite para fazermos juntos as aulas das turmas, introduzindo sua resposta por apreciação positiva, à qual está atrelado o julgamento, também positivo, do comportamento dos professores regentes de IFE: eu acho bom que vocês dão esse espaço pra gente pra gente dar sugestões também... e pra falar lá na frente e tal, que é seguido de uma proposição incompleta (em pra MIM que não tenho experiência). Interpreto que o interlocutor espera algo como 'isso foi' seguido de avaliação e, mesmo nessa incompletude, pode-se resgatar afeto evocado graduado com polaridade muito alta, que acaba envolvendo todas as avaliações anteriores nessa fala.

Nessas escolhas, Elis se diferencia dos professores regentes, nomeados como 'vocês', que representaria o que Duzak (2002) chama de 'os outros', ou seja, os diferentes da licencianda. Ao mesmo tempo emerge a identidade coletiva de 'estagiários' à qual ela assume pertencimento (SNOW, 2001), o que é indexado por 'a gente'. Por outro lado, Elis se distancia desses dois grupos ao se reconstruir como estagiária inexperiente nas linhas 148 e 149 (em pra MIM que não tenho experiência) a partir de julgamento negativo quanto à sua capacidade para a docência naquele momento, o que pode ser um fator gerador de dúvidas quanto à continuidade na profissão. Nota-se como essa perspectiva negativa quanto a si contrasta com a positividade do início de sua fala para se referir aos professores. Ela também diverge da visão sobre o assunto explorada 
em minha fala um pouco antes, o que é um exemplo de que nem sempre concordamos ou construímos as mesmas crenças em nossas conversas.

As escolhas que formam o 'pra MIM que não tenho experiência'podem suscitar, ainda, a leitura da construção de identidades de Elis como estagiária $e$ não-professora como pautada também na falta, ou melhor, na crença de que ela ainda não tem experiência para ser docente. Essa interpretação sugere que, em seu processo de tornar-se professora, Elis pode dar pouca importância ao seu conhecimento prévio em outros tipos de experiência diferentes de 'dar aulas, falar lá na frente e tal' (como a sua experiência como discente, citada por MARCELO, 2009, como essencial na constituição de identidades docentes). Conjuntamente, essa análise gerou perguntas sobre que visões nós (estagiários e professores) temos sobre 'experiências' e sua relação com a formação docente, assunto que não foi desenvolvido com esse grupo de estagiários participantes da pesquisa dessa tese, mas que já foi um dos frutos deste trabalho como tópico de discussão dentro da minha comunidade de prática e com os licenciandos recebidos posteriormente.

Ainda sobre as linhas 148 e 149 da Conversa 1, podem-se depreender emoções/ crenças de insegurança e autodepreciação na construção identitária de Elis ao se avaliar pela escolha do julgamento negativo de capacidade. Ela deixa claro que sua avaliação se restringe a si mesma, reforçando (com gradação) o pra MIM, pelo qual se distingue (cf. princípio de relacionalidade, distinção) de Carla (eu, uma das professoras regentes) e de Enzo (que já era professor de curso de idiomas). Entendo pela minha resposta e a de Enzo que, nessa interação, nós coconstruímos com Elis sua identidade como estagiária novata/inexperiente que precisa de apoio de seus pares (linhas 150 a 153).

Em nossas falas, eu e Enzo assumimos a identidade de "par mais competente', como denominado por Vygotsky (1998), buscando formas de ajudar Elis a avançar em sua aprendizagem compartilhando um pouco da nossa. Assim, oferecemos apoio usando nossas experiências para tentar afastar a insegurança de Elis (associada à sua avaliação negativa sobre si), assegurando que a tensão de principiante será superada e dando um exemplo (Enzo tremendo para mostrar seu nervosismo em sua primeira aula, que alude à crença de ser normal se sentir assim). Já Elis parece muito mais reconfortada com o nosso apoio e o avalia, juntamente com outras experiências no estágio, utilizando recursos avaliativos de afeto: É um alívio que... quando eu chegar em uma esco:la eu já vou ter essa experiência. Da opção por 'alívio' também pode-se inferir que sua 
integração ao ambiente escolar como professora está envolta em crençasemoções-identidades de insegurança.

Como afirma Marcelo (2009), a inserção profissional no ensino, como é o caso do estágio, é um período tenso que faz parte da constituição de identidades docentes. Para lidar com essa tensão, acredito que devemos promover a confiança, corroborando o que dizem Mahn e John-Steiner (2002), mas aqui com o foco nas relações de ensino-aprendizagem ${ }^{45}$ entre nós, docentes em formação (estagiários, regentes, professores de Prática de Ensino), no contexto do estágio. Desse modo, acredito que nós estamos em um processo incessante de desenvolvimento e que o estágio é um momento marcante nessa caminhada e requer especial cuidado e dedicação de todos, dando suporte de forma atenciosa e acolhedora aos seus pares, especialmente aos estagiários. Entretanto, para que isso ocorra, precisamos criar espaços para o compartilhamento não só de experiências, conhecimentos, materiais e práticas, mas também de afeição, bem como para o questionamento de nossas crenças e emoções e a (re/co) construção de nossas identidades. A conversa 2 é um exemplo de um dos momentos em que nos dedicamos a falar sobre como nós nos sentíamos, como podemos observar no trecho a seguir.

\section{Conversa 2 - "Eles que dão segurança"}

\begin{tabular}{|r|c|l|}
\hline 1 & Carla & como é que você se sentiu da primeira vez? du: \\
\hline 2 & Elis & >é que da primeira vez eu não tava tão nervosa< eu fiz o material mas \\
\hline 3 & & eu não sabia que eu ia... conduzir \\
\hline 4 & Carla & Hurrum \\
\hline 5 & Elis & acho que acho que era é: foi sexta feira que ela me avisou \\
\hline 6 & & tipo "amanhã você vai conduzir a atividade tá bem?" aí eu é \\
\hline 7 & & que da minha... nem deu muito tempo de me desesperar muito \\
\hline 8 & & [fui fazendo] ( (fala rindo)) . \\
\hline 9 & Ana & [dá um pânico, né] \\
\hline 10 & Enzo & é... é muito: \\
\hline 11 & Carla & deu nervoso no início... mas depois foi né... ou não? \\
\hline 12 & Elis & é: eu não sei... eu sempre tinha a impressão assi:m "fui tão mal \\
\hline 13 & Elis & mas os alunos gostaram" (.) E EIES GoSTARAM \\
\hline 14 & Carla & hurrum \\
\hline 15 & Elis & então... são eles que dão segurança... você fica nervoso... ao mesmo \\
\hline 16 & & tempo você se sente EELIZ né ... de você ter conseguido fazer \\
\hline
\end{tabular}

Nessa conversa, Elis fala de sua primeira vez conduzindo uma atividade com uma turma e todos nós (eu, Elis, Ana e Enzo) coconstruímos esse momento como tenso para o professor. Entendo que nas linhas 2, 3 e de 5 a 8, Elis se posiciona, por meio de afeto como elaboradora de materiais e praticante de IFE mais confiante, mas insegura quanto a conduzir a atividade com a turma,

45 Parto da premissa de que ensinamos e aprendemos uns com os outros e com nossas experiências. 
fazendo com que haja uma difusão de crenças-identidades-emoções, como 'não tão nervosa' (linha 2) e 'um pouco desesperada' (linha 7), mas resiliente, já que ela não se deixou vencer pelo medo e 'foi fazendo' (linha 8). Logo depois, ela avalia, por julgamento positivo, com gradação muito alta e com engajamento de contração dialógica, a impressão dos alunos sobre sua aula (em 'mas os alunos gostaram, E ELES GOSTARAM'), o que se contrapõe ao julgamento negativo de Elis sobre si mesma (em fui tão mal) e parece suplantá-lo. Além disso, apesar de asseverar sua construção como dependente da perspectiva do outro (em são eles que dão segurança), Elis se reformula como capaz e interliga toda essa difusão de identidades, crenças e sentimentos, o que emerge com base em afeto em sua conclusão nas linhas 15 e 16: você fica nervoso... ao mesmo tempo você se sente FELIZ né ... de você ter conseguido fazer. Também podemos entender que, por meio desses recursos avaliativos, Elis mostra uma perspectiva muito mais positiva quanto à docência, ao contexto escolar e a si mesma, parecendo bem mais propensa a seguir como professora.

A escolha pela carreira docente é abordada por Elis de forma mais evidente em seu primeiro diário, quando ela traz passado e presente para repensar suas experiências em sua caminhada para tornar-se professora. Avancemos, então, para algumas possíveis interpretações a partir do Excerto 1:

Diário 1 - Excerto 1

\begin{tabular}{|l|l|}
\hline 1 & Minha experiência como estagiária no IFRJ até o momento tem sido melhor \\
\hline 2 & do que o esperado. Antes de entrar para a faculdade de Letras (e até \\
\hline 3 & mesmo durante a maior parte da minha graduação, mesmo fazendo \\
\hline 4 & licenciatura) nunca tive a intenção de ser professora porque achava que \\
\hline 5 & não daria conta de tanta responsabilidade e porque tinha medo de como \\
\hline 6 & os alunos me tratariam. Mas por enquanto todas as turmas nos trataram \\
\hline 7 & bem e os alunos que falaram comigo foram amistosos. Fiquei feliz quando me \\
\hline 8 & fizeram perguntas porque não pensei que poderia ensinar algo para alguém \\
\hline 9 & e agora vejo que isso é possível. \\
\hline
\end{tabular}

Logo no início do texto, Elis se reconhece como estagiária no IFRJ, o que entendemos por meio do princípio de indexicalidade, já que ela marca de onde fala naquele contexto. A essa identidade também está vinculada a de insegura, que é construída por estar entrelaçada à crença/emoção de receio de que a experiência do estágio não seria muito boa, interpretação que pode ser feita com base nas escolhas lexicogramaticais e semânticas de Elis, que comento a seguir. 
Já em sua introdução, nota-se o tom de apreensão que permeia todo o seu texto, inicialmente de forma latente: ao invés de classificar a experiência no estágio explicitamente (usando opções como 'agradável', 'excelente', 'ruim' ou 'péssima', por exemplo), seus sentimentos são encapsulados como 'o esperado' (em melhor do que o esperado, na linha 2), que se trata de uma nominalização, recurso pelo qual, segundo Matthews (2014), elementos gramaticais, até uma oração, podem derivar em um substantivo. Desse modo, à primeira vista apreende-se que Elis avalia sua experiência no estágio sem se incluir, por apreciação positiva, mas essa seleção encobre afeto inscrito (de que era Elis quem esperava que a experiência não fosse tão boa), que é negativo, de insegurança.

É fato que o afeto permeia todas as instâncias avaliativas, como explicitado na seção 3.4.3. Entretanto, não entendo que exista apenas sentimento realizado como apreciação, mas que realmente possamos recuperar uma instância de afeto nessa escolha de maior densidade lexical com a nominalização, que acaba intensificando o significado atitudinal a ser esmiuçado, ou melhor explicitado posteriormente. Inclusive a circunstância até o momento (linha 2) contribui para a leitura de sua construção como uma estagiária insegura, que temia 'mudanças para pior' e essa insegurança vai sendo deslindada e se tornado mais aparente no decorrer do texto pela recorrência cada vez maior às escolhas dentro do campo do afeto de forma clara, fazendo dele a base para a construção discursiva de suas identidades-crenças-emoções no contexto do estágio.

Primeiramente, no Diário 1, Elis constrói a identidade de não futura professora, que emerge por meio de afeto negativo com gradação alta (em nunca tive a intenção de ser professora, no Excerto 1, linha 4). Isso parece muito contraditório, posto que ela escolheu fazer licenciatura em Letras e sua menção a esse paradoxo em meio à apresentação de um complexo de circunstâncias das linhas 2 a 4 amplifica ainda mais essa gradação. Sua aversão preliminar à carreira docente não é explicada com base na desvalorização dos professores ou nas dificuldades do ambiente de trabalho, que foram tópicos muito citados pelos outros estagiários como desencorajadores. Na verdade, o que se segue no diário de Elis é a retomada ${ }^{46}$ dessa identidade de não futura professora a partir de emoções misturadas a crenças, que emergem hibridamente por afeto negativo de insegurança (como em tinha medo de

${ }^{46}$ Elis refere-se a essa identidade utilizando todos os processos no passado. 
como os alunos me tratariam, nas linhas 5 e 6; achava que não daria conta de tanta responsabilidade, nas linhas 4 e 5; e não pensei que poderia ensinar algo para alguém, nas linhas 8 e 9). Parece que, para Elis, a inserção na docência pelo estágio era dificultada por estar arraigada a crençasemoções muito negativas (principalmente ligadas à insegurança) que faziam parte da constituição de suas identidades e me pergunto se outros estagiários não passam por processos similares.

Elis (identificando-se como estagiária parte do grupo recebido nas aulas de inglês do IFRJ pelo 'nos') relata que teve uma recepção nas turmas bem diferente da que temia, avaliando os alunos por julgamento positivo em por enquanto todas as turmas nos trataram bem e foram amistosos, linhas 6 e 7). Entretanto, a modalização com a circunstância 'por enquanto' insinua sua hesitação em confiar totalmente no bom tratamento, sugerindo uma construção como cautelosa e desconfiada.

Chamo a atenção para o fato de a única avaliação positiva de Elis quanto a si mesma ser proporcionada pelos outros, o que também a constrói como insegura: Elis diz que ficou feliz (linha 7) - que é uma avaliação no campo semântico de afeto dentro da categoria felicidade - quando os alunos fizeram perguntas para ela. Por outro lado, interpreto que essa alusão expressa a importância da empatia por parte dos outros integrantes do estágio, inclusive dos alunos, para a criação de um ambiente favorável para o florescimento da segurança e da confiança. Acredito que a integração de Elis como participante (não apenas observadora) no dia-a-dia do estágio e seu acolhimento como alguém a quem 'a turma se dirige para perguntar' pode ter colaborado para o questionamento de suas identidades-crenças-emoções negativas quanto à docência e sua aprendizagem no processo de tornar-se professora. Dessa maneira, parece que ela começa a caminhar em seu entendimento como docente, que também é fomentado pelo o olhar do outro, em uma construção cooperativa a partir do suporte de seus pares.

As escolhas ligadas ao passado para se referir à sua não intenção de tornarse docente, em contraste com o presente marcado pelo agora (linha 9), aventam a leitura de que Elis se reformula como futura professora e de que talvez as experiências do estágio realmente tenham contribuído para essa reconstrução. Ao mesmo tempo, ainda emerge em suas opções avaliativas sua construção como estagiária insegura como parte do complexo de suas expressões identitárias (cf. princípio de parcialidade): sua seleção é agora vejo que isso é possível, 
usando modalização com nível de probabilidade baixo ao invés de mais próxima ao campo da certeza, o que remonta à dúvida de Elis quanto a se tornar professora e à falta de confiança em si. Além disso, o item avaliado não é ela mesma, mas sim 'isso' (ensinar algo para alguém, que pode ser recuperado na linha 8) e se trata de uma apreciação positiva. Entretanto, dentro de um eixo paradigmático, Elis tinha muitas outras escolhas, dentre elas dizer 'agora vejo que sou capaz', o que mostraria maior assertividade e confiança e traria o foco para si mesma por afeto - segurança. Ressalto a escolha de apreciação ao invés de afeto para questionar o porquê da inclinação de Elis a não direcionar avaliações positivas para si. Isso nos remete à sua construção como estagiária insegura, que continua presente em sua construção como futura professora, o que exemplifica como as identidades são sempre parciais, sendo impossível classificá-las apenas de uma forma.

Do que foi dito, é possível compreender ainda que, mesmo quando ocorrem reformulações nas identidades, esse processo é gradual, complexo e contextualmente dependente, como é o caso da reconstrução de Elis como futura professora. Essa reformulação parece ter sido influenciada pela experiência no IFRJ, que é considerada pela licencianda como 'outro motivo para se sentir melhor que antes', como podemos ver no próximo excerto:

\section{Diário 1 - Excerto 2}

\begin{tabular}{|r|l|}
\hline 10 & Também me sinto melhor por estar numa escola técnica porque assim saio \\
\hline 11 & do lugar comum (gramática) e vejo outra realidade. É uma experiência \\
\hline 12 & muito rica porque apesar de ter tido poucas aulas, já aprendi coisas \\
\hline 13 & interessantes (como fazer shampoo para cabelo). Acho que por causa disso \\
\hline 14 & tenho mais disposição para as aulas do que teria se fosse uma escola \\
\hline 15 & "tradicional" (por falta de palavra melhor) . \\
\hline
\end{tabular}

Nesse excerto, as asserções se remetem ao afeto positivo de 'se sentir melhor por estar em uma escola técnica' (na linha 10), sendo todas as outras avaliações subordinadas a esse domínio semântico. Assim, ao construir sua perspectiva sobre o IFRJ a partir de afeto, Elis parece criar uma maior aproximação com esse ambiente escolar de forma semelhante à que fez na Conversa 1, quando diz eu espero conseguir dar aula assim numa escola assim... em uma escola técnica (.) eu gostei mais do que ficar falando sobre gramática (.) não sou muito fã de gramática.

Tanto na Conversa 1 quanto no Diário 1, que foram dados gerados na mesma época, Elis se constrói, ao mostrar sua perspectiva, a partir das afinidades que encontrou com o instituto. Assim, na Conversa 1, ela se mostra como futura 
professora motivada a trabalhar em uma escola técnica, talvez por ver ali similaridades com algumas de suas crenças, sentimentos e com quem ela estava se tornando, o que é novamente avaliado por meio de afeto (em espero..., gostei...não sou muito fã...). Do mesmo modo, em seu primeiro diário, ela menciona compatibilidades com o ensino de inglês do IFRJ por meio de escolhas dentro do subsistema de atitude.

Além de carregadas de emoção, suas identidades como estagiária aprendiz / praticante de IFE/ futura professora emergem em suas avaliações permeadas por crenças que parecem contrapor a escola técnica ao ela chama de 'escola tradicional', sendo essa última, provavelmente o que era conhecido pela autora por suas vivências como aluna. Entende-se que Elis formula a crença no IFE como uma prática profícua e relevante (compreendida pelas avaliações positivas em experiência muito rica, aprendi coisas interessantes, por causa disso tenho mais disposição), o que destoa totalmente dos mitos ligados à abordagem, vista como somente "inglês técnico para leitura" e "sempre monótona" (como descrito por RAMOS, 2005). Ao mesmo tempo, parece que a positividade ligada à escola técnica foi construída em oposição à 'tradicional', à qual são ligadas crenças-emoções negativas, inferidas na comparação feita, por exemplo, em por causa disso tenho mais disposição do que teria se fosse uma escola "tradicional" dentro do campo do afeto. Ao dizer que ela tem 'mais disposição' no excerto 2 de seu diário, Elis parece estar no campo semântico de mais 'ânimo', 'vontade', 'energia', 'entusiasmo' e pode estar se referindo não só à prática do IFE, mas também à decisão por seguir a profissão docente. Isso parece se opor à identidade-crença-emoção de aversão à docência relatada no excerto 1, que pode estar sendo desconstruída a partir de suas experiências no estágio, como também pode ser interpretado do excerto 3 , mostrado a seguir.

Diário 1 - Excerto 3

\begin{tabular}{|r|l|}
\hline 16 & A verdade é que tudo isso é novo para mim, por ser meu primeiro estágio. \\
\hline 17 & Por muito tempo a ansiedade me atrapalhou, inclusive me tirando algumas \\
\hline 18 & oportunidades de trabalho em cursos de inglês. Sentia muita pressão \\
\hline 19 & porque todos que conheço na faculdade já davam aula e eu não. \\
\hline 20 & Mas cada um tem seu próprio caminho e hoje em dia não me preocupo \\
\hline 21 & mais com isso (pelo menos não tanto quanto antes) porque \\
\hline 22 & acredito que pra uma pessoa como eu é importante \\
\hline 23 & que as coisas aconteçam gradualmente, para que eu me acostume \\
\hline 24 & com minhas futuras funções, ao invés de ter que me "virar sozinha" \\
\hline
\end{tabular}


Nesse excerto, é possível compreender que Elis mostra-se em seu caminhar para a reformulação de algumas de suas identidades-crenças-emoções. Para tanto, ela retoma sua identificação como inexperiente não só no estágio (linha 16), mas também na docência (linha 19) para refletir sobre sua coconstrução nesse ambiente e no processo de tornar-se professora. Ao ler das linhas 17 a 19, percebemos a recorrência ao passado para mostrar como Elis se sentia e acreditava ser diferente dos colegas.

Tomando o princípio de relacionalidade (BUCHOLTZ; HALL, 2005), mais especificamente o par adequação/distinção, notamos que, dependendo do contexto, Elis pode destacar similaridades entre ela e seus colegas estagiários (como no Excerto 1), mas em outros momentos, salienta características que a diferenciam deles, principalmente se depreciando nessa distinção, como acontece no Excerto 3. Tal depreciação pode ser inferida pelas escolhas atitudinais negativas de afeto nos campos da insegurança (como em a ansiedade me atrapalhou) e da insatisfação (como em sentia muita pressão porque todos que conheço na faculdade já davam aula e eu não), que a constroem como não professora, inexperiente e insegura.

Até mesmo a forma como a ansiedade é retratada contribui para essa construção: Elis promove a ansiedade à posição de ator dos processos materiais atrapalhar e tirar (em Por muito tempo a ansiedade me atrapalhou, inclusive me tirando algumas oportunidades de trabalho, nas linhas 16 e 17) e relega a si a de meta. Na LSF, dentro do Sistema de Transitividade, classificamos os participantes dos processos materiais em ator, que é quem realiza a ação, e a meta, que é para quem a ação é dirigida. Essa distinção tornase relevante para a análise, posto que Elis faz escolhas lexicogramaticais que a colocam em uma posição de grande vulnerabilidade (pois é 'quem sofre a ação'), o que, juntamente com o uso de gradação em grau alto (em Por muito tempo e sentia muita pressão), dá ainda maior ênfase à sua insegurança.

Logo depois, com relação ao presente, Elis parece se construir de forma a desmistificar esse controle de sua vida por seus receios nas linhas 20 e 21 (em cada um tem seu próprio caminho e hoje em dia não me preocupo mais com isso). Nesse trecho, ela reelabora suas identidades-crenças-emoções de vulnerabilidade e depreciação construídas como parte de sua insegurança e se reconhece como pessoa (ou professora) 'em processo', o que se entende pela referência ao 'caminho', no qual 'ser diferente' também não é mais avaliado como negativo (já que cada um tem o seu). Com base nos princípios de parcialidade e 
posicionalidade, é possível dizer que ela não deixa de ser insegura, tanto que essa identidade emerge em pelo menos não 'me preocupo' tanto quanto antes (mesmo com a diminuição da gradação da avaliação por afeto que sustenta a mudança) e em pra uma pessoa como eu (que reitera sua construção, não necessariamente negativa, como diferente dos outros) - mas ela é ressignificada como parte de sua nova percepção de si e dos outros na posição como estagiária, futura professora e membro da comunidade de prática.

Além disso, entendo que, ao citar que é importante que as coisas aconteçam gradualmente, para que eu me acostume com minhas futuras funções em um ambiente em que ela não tem que se "virar sozinha" (linhas 22 a 24), Elis se constrói como futura professora por afeto que remete à segurança com relação ao estágio e ao apoio da comunidade de prática em sua caminhada identitária. Dessa forma, depreende-se a crença no estágio como momento do processo de formação docente onde o licenciando 'pode gradualmente se acostumar com suas futuras funções' e pode contar com o auxílio de seus pares. Suas primeiras impressões quanto à familiarização com o ambiente de estágio é o tema do Excerto 4.

Diário 1 - Excerto 4
\begin{tabular}{|r|l|}
\hline 24 & Em relação as turmas em si, percebi que gostei bastante \\
\hline 25 & das turmas de Meio Ambiente, tanto a da quinta quanto a de sábado. \\
\hline 26 & Sinto que os alunos dessas turmas são mais receptivos em relação a mim, \\
\hline 27 & mas é muito cedo pra dizer, já que ainda não tive muitas oportunidades \\
\hline 28 & de me enturmar com os alunos em geral. \\
\hline 29 & Também gosto da localização da escola. \\
\hline 30 & Quando se mora longe, essas coisas fazem muita diferença no dia-a-dia. \\
\hline 31 & Só tenho que pegar um ônibus e ele para bem em frente à escola. \\
\hline 32 & Só gostaria que o elevador estivesse funcionando \\
\hline 33 & porque subir tantas escadas é um pouco doloroso. \\
\hline
\end{tabular}

Como acontece nos outros trechos, no excerto 4, a base é o afeto, que é usado tanto para avaliar a si mesma em relação às turmas, bem como para nos oferecer sua perspectiva quanto à escola. Em primeiro lugar, ela parece novamente se basear na crença de que, como estagiária/futura professora deve estabelecer uma relação de proximidade com os alunos. As avaliações de afeto, dentro de felicidade quanto a algumas turmas (em gostei bastante das turmas de Meio Ambiente) e de segurança (em sinto que os alunos dessas turmas são mais receptivos a mim) a constroem como mais integrada ao estágio. Contudo, como em trechos anteriores, Elis se remete às identidades-emoções de insegurança ao quebrar a ideia construída de um 
esperado conforto pela receptividade dos alunos para se construir também pela crença-emoção de incerteza (com é muito cedo para dizer). Consequentemente, podemos inferir que ainda emerge a identidade de estagiária e futura professora insegura de forma persistente em suas avaliações, que constroem e são construídas conjuntamente por crenças e emoções.

Já no penúltimo parágrafo de seu diário, Elis concentra-se em algumas características do instituto por meio de recursos avaliativos de afeto (ao invés de apreciação, por exemplo, que traria foco na estética e menor envolvimento emocional). Acredito que essa opção também a constrói como estagiária/futura professora, pois Elis se inclui nessas avaliações e, por meio delas, ela pondera como estava se ajustando ao ambiente da escola. O único aspecto negativo, avaliado por afeto dentro das escalas de insatisfação com gradação baixa, é quanto ao uso das escadas ao invés do elevador. A opção lexicogramatical por "doloroso" é bem pertinente à construção de desconforto sentida pela estagiária se considerarmos as comparações entre o antes e o agora: nesta citação ela se refere ao presente como estagiária/ professora em processo e o desconforto é apenas físico, o que contrasta com o desconforto emocional do passado que a fazia 'não querer ser professora'. Para concluir, ela continua percorrendo uma estrada já não tão pavimentada de incertezas ao vislumbrar o futuro, como pode ser visto no último excerto do Diário 1:

Diário 1 - Excerto 5

\begin{tabular}{|l|l|}
\hline 34 & No mais, tento fazer com que o estágio seja uma boa experiência \\
\hline 35 & para mim como pessoa, estudante de Letras e futura professora. \\
\hline 36 & Inclusive, quando a hora chegar e se eu conseguir, \\
\hline 37 & gostaria de lecionar em uma escola técnica \\
\hline 38 & (o que é engraçado agora porque na escola \\
\hline 39 & nunca fui fã de química ou biologia, por exemplo) \\
\hline
\end{tabular}

Seguindo o princípio de indexicalidade, percebemos que Elis se reconhece como pessoa, estudante de Letras e futura professora (linha 35). Além disso, ela se constitui, por julgamento positivo de si mesma, como participante ativa não só no estágio, mas em sua própria construção (em tento fazer com que o estágio seja uma boa experiência para mim, como ator e não como meta - cf. Sistema de Transitividade) e não somente aquela a quem 'tratam de certa forma' e 'sofre pelo controle da ansiedade', como em menções anteriores.

Além disso, Elis usa recursos de afeto positivo e engajamento de contração dialógica para pronunciar seu desejo de se tornar professora de IFE 
em 'Inclusive,... eu gostaria de lecionar em uma escola técnica', o que sugere que ela se sentia mais convicta quanto à escolha pela profissão docente e adaptada ao nosso contexto. Apesar disso, Elis ameniza essa construção de maior segurança pelo uso de modalização (em se eu conseguir, linha 36), se reconstituindo como hesitante. De qualquer forma, pode-se inferir que há uma reformulação de suas identidades-crenças-emoções pela criação de afinidades conosco. Assim, é possível entender que, tanto o fato de relegar ao passado avaliações por afeto negativo sobre disciplinas como química e biologia (insinuando que mudou de opinião sobre elas, nas linhas 38 e 39), quanto sua avaliação, por afeto positivo, da possibilidade de dar aulas em um lugar como o IFRJ, a reconstroem como estagiária membro de nossa comunidade de prática e talvez futura professora de IFE.

As possíveis interpretações analisadas nesta seção sugerem que Elis nos conduz por sua caminhada questionando e ressignificando algumas de suas identidades, crenças e emoções, principalmente pelas experiências no estágio, proporcionando sua reformulação como futura professora. Com o objetivo de melhor visualizar as (re)construções de Elis em seu processo decisório pela carreira docente, proponho o quadro 9:

\begin{tabular}{|c|c|c|}
\hline DADOS & (RE)CONSTRUÇÕES IDENTITÁRIAS & RECURSOS DISCURSIVOS \\
\hline $\begin{array}{c}\text { Conversa } 1 \\
\text { Excerto } 7\end{array}$ & $\begin{array}{l}\text { - Coconstruções de identidades de professora regente } \\
\text { participante/pesquisadora para Carla e de } \\
\text { estagiários/alunos participantes para Elis e } \\
\text { Enzo. } \\
\text { - Diferente dos professores regentes } \\
\text { - Estagiária e não-professora } \\
\text { - Emoções/ crenças de insegurança e } \\
\text { autodepreciação na construção identitária de Elis , } \\
\text { que se distingue de Carla (eu, uma das professoras } \\
\text { regentes) e de Enzo (que já era professor de curso } \\
\text { de idiomas) e se coconstrói conosco como } \\
\text { estagiária novata e inexperiente que } \\
\text { precisa de apoio de seus pares }\end{array}$ & $\begin{array}{c}\text { Princípios de } \\
\text { indexicalidade, de } \\
\text { posicionalidade e de } \\
\text { relacionalidade (distinção) } \\
\text { Apreciação positiva } \\
\text { atrelada ao julgamento } \\
\text { positivo dos professores } \\
\text { regentes } \\
\text { Julgamento negativo de sua } \\
\text { capacidade para a docência } \\
\text { Afeto (segurança) quanto ao } \\
\text { futuro, do qual se infere a } \\
\text { crença-identidade-emoção de } \\
\text { insegurança quanto ao } \\
\text { estágio }\end{array}$ \\
\hline $\begin{array}{c}\text { Conversa } 2 \\
\text { "Eles que dão } \\
\text { segurança" }\end{array}$ & $\begin{array}{l}\text { - Elaboradora de materiais e praticante de } \\
\text { IFE mais segura } \\
\text { - Difusão de identidades-crenças-emoções: 'não tão } \\
\text { nervosa', 'um pouco desesperada', } \\
\text { resiliente, insegura, capaz } \\
\text { - Dependente da perspectiva do outro }\end{array}$ & $\begin{array}{l}\text { Julgamento positivo, com } \\
\text { gradação muito alta e com } \\
\text { engajamento de contração } \\
\text { dialógica } \\
\text { Julgamento negativo de si } \\
\text { mesma, o que é suplantado } \\
\text { pelas avaliações positivas } \\
\text { na relação com os outros } \\
\text { Afeto como base }\end{array}$ \\
\hline
\end{tabular}




\begin{tabular}{|c|c|c|}
\hline $\begin{array}{c}\text { Diário } 1 \\
\text { Excerto } 1\end{array}$ & $\begin{array}{l}\text { Com relação ao passado, emergem crenças-emoções- } \\
\text { identidades de estagiária insegura e de não } \\
\text { futura professora. } \\
\text { Com relação ao presente, Elis se constrói como: } \\
\text { - Estagiária no IFRJ } \\
\text { - Possivelmente, futura professora, sendo que o } \\
\text { entendimento como docente está muito conectado à } \\
\text { perspectiva dos outros, mostrando a necessidade de } \\
\text { suporte de seus pares } \\
\text { - Ainda insegura, cautelosa e desconfiada } \\
\text { pelo o receio de a experiência do estágio ser tão } \\
\text { angustiante como as que teve antes na escola e de } \\
\text { 'mudanças para pior'. }\end{array}$ & $\begin{array}{l}\text { Afeto negativo evocado de } \\
\text { insegurança, dentro de uma } \\
\text { nominalização, o que é } \\
\text { seguido de várias instâncias } \\
\text { de afeto negativo com } \\
\text { gradação alta para avaliar o } \\
\text { passado. } \\
\text { Princípios de emergência, } \\
\text { de parcialidade e de } \\
\text { indexicalidade } \\
\text { Julgamento positivo dos } \\
\text { alunos e afeto (felicidade) } \\
\text { por ser bem tratada por eles }\end{array}$ \\
\hline $\begin{array}{c}\text { Diário } 1 \\
\text { Excerto } 2\end{array}$ & $\begin{array}{l}\text { - Crenças-identidades-emoções de aluna } \\
\text { insatisfeita no passado com o que ela chama de } \\
\text { 'escola tradicional' o que é contraposto com sua } \\
\text { construção no presente como estagiária, } \\
\text { aprendiz e praticante de IFE na escola técnica } \\
\text { - Crença no IFE como uma prática proficua e } \\
\text { relevante, o que destoa totalmente dos mitos } \\
\text { normalmente ligados à abordagem. }\end{array}$ & $\begin{array}{l}\text { Princípios de emergência, } \\
\text { de parcialidade e de } \\
\text { posicionalidade } \\
\text { Afeto positivo }\end{array}$ \\
\hline $\begin{array}{c}\text { Diário } 1 \\
\text { Excerto } 3\end{array}$ & $\begin{array}{l}\text { - Alguém que "nunca teve a intenção de ser } \\
\text { professora"; } \\
\text { - Alguém cujas oportunidades foram tiradas } \\
\text { e que foi atrapalhada pela ansiedade no } \\
\text { passado; } \\
\text { - Não professora/ inexperiente. } \\
\text { - Estagiária muito insegura por antes se sentir } \\
\text { angustiada e ter sido sofredora (pela pressão e pelo } \\
\text { receio), mas que estál se entende / se sente melhor } \\
\text { quanto à docência com as experiências no estágio; } \\
\text { - Diferente das outras pessoas (em "pessoa } \\
\text { como eu"), que precisa de mais tempo para se } \\
\text { adaptar; } \\
\text { - Reelaboração suas emoções/crenças/identidades de } \\
\text { vulnerabilidade e depreciação construídas como } \\
\text { parte de sua insegurança por se reconhecer como } \\
\text { pessoa (ou professora) 'em processo', o que } \\
\text { se entende pela referência ao 'caminho', no qual 'ser } \\
\text { diferente' pode não ser negativo (já que cada um } \\
\text { tem o seu). } \\
\text { - Estagiária/ futura professora/membro da } \\
\text { (e apoiada pela) comunidade de prática }\end{array}$ & $\begin{array}{l}\text { Princípios de emergência, } \\
\text { de parcialidade e de } \\
\text { relacionalidade (por } \\
\text { adequação e distinção) } \\
\text { Uso recorrente de escolhas } \\
\text { atitudinais negativas de } \\
\text { afeto nos campos da } \\
\text { insegurança e da } \\
\text { insatisfaçãa para se referir as } \\
\text { experiências escolares do } \\
\text { passado } \\
\text { Organização dentro do } \\
\text { sistema de transitividade de } \\
\text { forma que a ansiedade é ator } \\
\text { e a licencianda é meta. } \\
\text { Afeto evocado que remete à } \\
\text { segurança }\end{array}$ \\
\hline $\begin{array}{c}\text { Diário } 1 \\
\text { Excerto } 4\end{array}$ & $\begin{array}{l}\text { - Crença de que, como estagiária/futura } \\
\text { professora deve estabelecer uma relação de } \\
\text { proximidade com os alunos } \\
\text { - Crenças/emoções de insegurança quanto a si, que } \\
\text { constroem a (e que são construídas pela) identidade } \\
\text { de estagiária insegura }\end{array}$ & $\begin{array}{l}\text { Afeto positivo de felicidade } \\
\text { e de segurança } \\
\text { Gradação diminuindo a } \\
\text { positividade (em 'é muito } \\
\text { cedo para dizer') }\end{array}$ \\
\hline
\end{tabular}




\begin{tabular}{|c|c|c|}
\hline $\begin{array}{c}\text { Diário } 1 \\
\text { Excerto } 5\end{array}$ & $\begin{array}{l}\text { - Pessoa, estudante de Letras e futura } \\
\text { professora } \\
\text { - Participante ativa não só no estágio, mas } \\
\text { em sua própria construção (como ator e não } \\
\text { não aquela a quem 'tratam de certa forma' e que } \\
\text { 'sofre pelo controle da ansiedade', como antes). } \\
\text { - Mais convicta quanto à escolha pela profissão } \\
\text { docente e adaptada ao nosso contexto } \\
\text { - Estagiária membro de nossa comunidade } \\
\text { de prática e talvez futura professora de IFE }\end{array}$ & $\begin{array}{l}\text { Princípios de emergência e } \\
\text { de indexicalidade } \\
\text { Julgamento positivo de si } \\
\text { mesma } \\
\text { Afeto positivo e } \\
\text { engajamento de contração } \\
\text { dialógica para pronunciar } \\
\text { seu desejo de se tornar } \\
\text { professora de IFE }\end{array}$ \\
\hline
\end{tabular}

Fonte: Análise dos dados da pesquisa

Novamente, no quadro 9, uso as setas em alguns momentos em que as reformulações identitárias de Elis ficam mais evidentes. Nesses excertos, as análises sugerem que houve uma grande transformação: Elis relega ao passado crenças-identidades-emoções de insegurança quanto ao ambiente escolar e, ao mesmo tempo, se constrói, a partir das experiências no estágio (principalmente nas relações interpessoais), como mais confortável naquele contexto, entendendo-se como 'em processo', estagiária cada vez mais experiente e certa de seguir a profissão docente, expressando até o desejo de se tornar professora de IFE. Essas reconstruções emergem de diferentes escolhas avaliativas, principalmente de afeto positivo quanto às experiências no estágio e à sua adaptação ao nosso contexto, mostrando seu grande comprometimento emocional em sua caminhada. Na próxima subseção, são analisados outros excertos nos quais são analisadas as (re)construções de Elis em relação a esse contexto com foco em sua integração em nossa comunidade de prática.

\subsection{3}

\section{(Re)construções de Elis como membro da nossa comunidade de prática de IFE}

Pela análise do Diário 1, pode-se interpretar que Elis se reconstrói como membro de nossa comunidade de prática a partir das afinidades encontradas durante a sua caminhada conosco no estágio. No último excerto do Diário 1, sua mudança é enfatizada ao avaliar seu novo desejo de ser professora de IFE como 'engraçado' (por meio de apreciação positiva, na linha 38). Porém, essa opção lexicogramatical não tem o sentido de 'risível' mas se aproxima mais de um grupo paradigmático formado por expressões como 'curioso e surpreendente' e se trata também de um recurso de engajamento de contraexpectativa. Elis usa esse mesmo recurso (é engraçado) no vídeo que gravou no final do estágio no instituto, onde ela novamente chama a atenção para a sua reformulação de 
crenças, identidades e emoções, que também parece ter sido promovida por suas experiências conosco.

Vídeo - Excerto 1 - “Agora eu quero ser professora de IFE”
\begin{tabular}{|r|l|}
\hline 1 & meu nome é Elis e eu sou (.) aluna da faculdade de letras UFRJ \\
\hline 2 & faço português inglês licenciatura... e fiz o meu estágio \\
\hline 3 & supervisionado na escola técnica ... no IFRJ e bom \\
\hline 4 & pra mim a experiência do estágio foi crucial para a minha formação \\
\hline 5 & porque: foi o meu primeiro estágio na área du: na área da docência \\
\hline 6 & então pra mim foi quase que um teste pessoal e profissional assim \\
\hline 7 & será que isso é uma coisa que eu consigo fazer? \\
\hline 8 & será que eu me vEjo no futuro fazendo isso daqui pra frente? \\
\hline 9 & e: é engraçado ... porque agora eu quero ser professora de IFE ( (rindo) ) \\
\hline 10 & eu quero vir pra cá (.) claro que algum dia... ainda tenho que \\
\hline 11 & trabalhar muito para chegar aqui porque também eu sei \\
\hline 12 & que o professor nunca fica em uma coisa só >ele dá aula \\
\hline 13 & em muitas escolas... em cursos... dá aula em universidades< então (.) vou \\
\hline 14 & tentar chegar aqui... mas até lá né eu vou passar por outros caminhos \\
\hline 15 & e: : : eu quero que essa disciplina ela fique na minha vida .. disciplina \\
\hline 16 & eu digo tanto no sentido de conduta quanto no sentido da matéria da escola \\
\hline 17 & que ela permaneça na minha vida porque é: eu aprendi muita coisa aqui \\
\hline
\end{tabular}

No Excerto 1 do Vídeo, Elis se posiciona e se inscreve como aluna de Letras e estagiária experiente das linhas 1 a 3 (cf. princípio de posicionalidade e indexicalidade de BUCHOLTZ; HALL, 2005) e avalia o estágio como crucial, opção que confere à apreciação positiva uma gradação muito alta. Assim, parece que, como defende Lüdke (2009, p. 101), o estágio é um "ponto nevrálgico" no processo identitário de Elis: ele é descrito pela licencianda como 'quase um teste' para refletir sobre suas dúvidas para tornar-se docente (que, como ela lembra na linha 6, não eram apenas de ordem profissional, mas também pessoal).

Para ilustrar sua reformulação durante o período de pré-serviço, ela traz crenças-emoções-identidades que emergem nas avaliações por julgamento quanto à sua própria capacidade nas linhas 7 e 8 (em será que isso é uma coisa que eu consigo fazer? será que eu me VEjo no futuro fazendo isso daqui pra frente?). Elas mostram como Elis estava insegura no passado, o que contrasta com sua conclusão nas linhas 9 e 10, introduzida pela expressão 'é engraçado', que quebra a expectativa e sugere que ela já não se entende mais daquela forma. Ao contrário, suas escolhas para avaliar como se sente/entende naquele momento (agora, linha 9) estão no domínio do afeto positivo (em porque agora eu quero ser professora de IFE, eu quero vir pra cá), pelo qual ela se reconstrói como decidida a seguir a carreira $e$ aspirante a docente de IFE como integrante do IFRJ. 
No entanto, ela se entende como ainda não pronta para lecionar em uma escola técnica, o que é construído por meio de julgamento em ainda tenho que trabalhar muito para chegar aqui (linhas 10 e 11). Dessa avaliação, e da explicação que a segue, parecem emergir algumas crenças, como a de que a profissão docente exige a atuação em diferentes instituições (o que pode ser depreendido de o professor nunca fica em uma coisa só, linha 12); de que deve haver o acúmulo de outras experiências escolares antes de ingressar como docente em escolas como o instituto; e de que existe uma maior dificuldade para ser admitido como professor em escolas federais (que podem ser entendidas por escolhas como algum dia, vou tentar chegar aqui e até lá vou passar por outros caminhos na linha 15), concepções que poderiam ser melhor exploradas em discussões junto à nossa comunidade.

Por escolhas avaliativas de afeto positivo evocado (linhas 15 a 17), Elis se identifica como praticante de IFE, declarando querer manter essa identidade (por engajamento- contração dialógica e gradação, na repetição de 'quero que essa disciplina fique, permaneça em minha vida', nas linhas 15 e 17). De sua avaliação, também emerge a crença de que o IFE não se restringe a 'uma matéria escolar', mas que pode ser considerado como uma 'conduta', que parece refletir nossa concepção da abordagem como um conjunto de práticas, que envolve interesses, experiências, atividades, temas e preocupações que fazem parte de nossas identidades como comunidade.

Outro tópico que surgia recorrentemente em nossas conversas, algumas registradas nos dados, é a crença compartilhada por nós praticantes de IFE, de que a gramática não deve ser o foco do ensino de línguas. Essa crença é constantemente construída por Elis imbricada em emoções, por meio de afeto, a partir de experiências de antes e durante o estágio e parece estar fortemente conectada às suas identidades pessoais e profissionais - como pode ser depreendido do excerto 7 da Conversa 1 (em eu gostei mais do que ficar falando sobre gramática... não sou muito fã de gramática), do excerto 2 do Diário 1 em que ela chama a gramática de 'lugar comum', do qual ela se sente melhor em sair; e do início do excerto 4 da Conversa 1, transcrito a seguir.

Conversa 1 - Excerto 4 - “Fica uma coisa mais livre assim de se trabalhar"
\begin{tabular}{|r|l|l|l|}
\hline 56 & Elis & e eu também gostei de a gente não focar \\
\hline 57 & & muito na gramática... não ter um livro como tem no curso de \\
\hline 58 & & inglês... porque fica uma coisa mais livre assim de se trabalhar \\
\hline 59 & Carla & o que vocês acham de nós fazermos uma apostila pra seguir? \\
\hline 60 & & vocês acham que seria possível aqui? apostila? \\
\hline
\end{tabular}




\begin{tabular}{|l|l|l|}
\hline 61 & Elis & poderia até ser possível... mas não sei se seria a melhor opção \\
\hline 62 & & porque tem as notícias que a gente pode sempre estar utilizando \\
\hline 63 & & com um livro isso não seria tão possível \\
\hline 64 & Enzo & tem umas partes positivas e outras negativas né \\
\hline 65 & Carla & exatamente (.) às vezes é até poderia se dizer talvez um fardo muito \\
\hline 66 & & grande de ter que preparar tu: do \\
\hline 67 & Enzo & você se prende também (.) eu geralmente fico meu final de semana \\
\hline 68 & & inteirinho preparando aula... isso porque já passei a semana \\
\hline 69 & & inteirinha pensando na aula pra chegar sábado sentar e fazer... \\
\hline 70 & & mas agora tem a questão que o livro prende muito também né (.) \\
\hline 71 & & mas não é você que prende (.) às vezes você quer ir além e \\
\hline 72 & & substituir algo do livro e o aluno não quer...ele comprou o livro e \\
\hline 73 & & ele quer usar o livro \\
\hline 74 & Elis & tem isso também... eles aqui não são tão presos ao livro \\
\hline 75 & Carla & não... não aqui não tem livro... simplesmente não tem... \\
\hline 76 & & além do fato ... assim ... aqui é inglês para fins específicos... \\
\hline 77 & & que livro que vai dar conta de meiio ambiente alimentos \\
\hline 78 & & [biotecnologia farmácia química?] \\
\hline 79 & Elis & [teria que ser um livro pra cada curso] \\
\hline 80 & Enzo & lá na faetec tinha uma apostila pra cada série e cada curso \\
\hline 81 & & só que honestamente não funcionava muito não ... não era inglês \\
\hline 82 & & específico \\
\hline 83 & Carla & é complicado né (.) aqui por exemplo ... na química foram \\
\hline 84 & & admitidos novos elementos, né... então a gente não usa o mesmo \\
\hline 85 & & texto para a tabela periódica ... a gente prefere usar outro texto \\
\hline 86 & & todo período ... não digo nem todo ano ... todo PERíoDo o material \\
\hline 87 & & é renovado (.) não tanto quanto a gente gostaria porque é \\
\hline 88 & & impossível... humanamente impossível (.) mas é até as necessidades \\
\hline 89 & & deles mudam também... quando eu entrei aqui a necessidade não \\
\hline 90 & & era tão grande da modalidade oral ... hoje em dia pede-se bastante \\
\hline 91 & & pra eles fazerem entrevistas em outras instituições por exemplo e \\
\hline 92 & & a gente prepara eles pra entrevista em inglês (..) quer dizer mudou \\
\hline
\end{tabular}

Assim como em outros momentos, em nossa primeira conversa gravada, Elis discorre sobre suas afinidades com o IFE por meio de emoções (por afeto, felicidade) e se identifica como estagiária praticante da abordagem $e$ membro da comunidade de prática por adequação (cf. BUCHOLTZ; HALL, 2005) ao usar 'a gente' em eu também gostei de a gente não focar muito na gramática... não ter um livro como tem no curso de inglês ... fica uma coisa mais livre assim de se trabalhar (linhas 56 a 58). Podemos perceber que, desde o início do estágio, Elis já se identifica com vários de nossos preceitos, inclusive se mostrando favorável à autonomia docente, no sentido de ver como positivo o fato de poder elaborar e adaptar suas aulas e materiais com os outros professores e alunos, mas sem uma imposição institucional, que é um aspecto fundamental para o professor de IFE, como afirma Fontana (2008). Desse modo, suas escolhas sugerem que Elis já se sente integrada ao grupo a partir de perspectivas comuns, ou melhor, de identidadescrenças-emoções compartilhadas com a comunidade de prática de IFE do instituto. 
A questão do não uso de livros didáticos, trazida por Elis como um ponto positivo na conversa, é problematizada por mim a partir da posição de professora e membro mais experiente da comunidade de prática. Eu tinha a intenção de convidar Elis e Enzo a questionarem isso ao perguntar sobre a possibilidade de usarmos apostilas como material didático. Pelas respostas deles, parece que ambos creem que livros e apostilas podem ser considerados como se fossem sinônimos (talvez por acreditarem, como nós, que eles acabam sendo muito similares em sua concepção e no uso) e avaliam esses materiais como inadequados para o IFRJ, o que ecoa nossa crença como equipe no instituto.

Entretanto, diferente de Enzo, que é mais categórico, Elis é muito menos assertiva por utilizar muitas formas de modalização de probabilidade baixa, como em poderia até ser possível... mas não sei se seria a melhor opção porque tem as notícias que a gente pode sempre estar utilizando. A seleção de recursos de engajamento de expansão dialógica para mostrar seu posicionamento sugere a emergência da identidade de colaboradora com perfil integrador (que dá a sua opinião sem descartar outras). Entretanto, ao considerarmos o restante do Excerto 4, parece que Elis também está se coconstruindo como membro menos experiente na comunidade de prática enquanto eu e Enzo falamos como professores elaboradores de aulas e materiais didáticos (por exemplo, ao mencionarmos aspectos negativos, como o tempo gasto, nas linhas 67 a 69, e a dificuldade, como em 'fardo muito grande', linhas 65 e 66). Tal coconstrução pode ser percebida nas relações de poder e nos papeis dos participantes da interação (cf. princípio de posicionalidade, p. 40).

Primeiramente, a forma como eu e Enzo conduzimos o assunto nesse excerto, com exemplos de nossa prática, restringe a inserção de Elis, que não tem o mesmo tipo de experiência com elaboração de aulas e materiais. Ela participa endossando o que está sendo dito (como em tem isso também) e usando sua vivência no estágio (eles aqui não são tão presos ao livro, linha 74). Porém, minha fala com forte contração dialógica das linhas 75 a 78 (com uma pergunta retórica final e iniciando com quatro negativas em não... não aqui não tem livro... simplesmente não tem... que parecem tentar corrigir Elis), assevera minha posição de poder e identidade como professora/membro experiente da comunidade de prática, ao mesmo tempo que ajuda a construir Elis como estagiária/ membro menos experiente.

Nota-se ainda que, a partir da linha 74 e minha interferência, Elis tem apenas uma breve participação no restante do excerto 4 (Conversa 1) com fala sobreposta 
à minha (em teria que ser um livro pra cada curso na linha79). A isso se soma também a forma de Enzo discordar de Elis, novamente usando sua experiência prévia, mas agora como aluno de ensino médio. A partir daí, tomo o turno para 'ensinar' nossa visão na equipe de IFE quanto aos materiais, usando vocabulário e exemplos específicos do nosso contexto, ocupando a posição de professora regente e membro experiente.

Em resumo, pode-se interpretar que, em parte do Excerto 4 da Conversa 1, há alinhamento entre eu e Enzo e nosso afastamento (e até um certo ofuscamento) de Elis na construção de nossas crenças-identidades, principalmente devido ao posicionamento que nós três assumimos naquele momento. No entanto, em um ponto mais adiante no estágio (outro momento de sua caminhada identitária), quando Elis parece estar mais integrada e segura dentro da comunidade de prática, vemos como ela oferece seu apoio a uma outra colega, reconstruindo-se como estagiária e membro mais experiente.

\begin{tabular}{|c|c|c|}
\hline 1 & Carla & e aí... o que você tá achando até agora? \\
\hline 2 & Léa & estou sentindo muita diferença \\
\hline 3 & Carla & em quê? \\
\hline 4 & Léa & na verdade insegurança porque: : eu tenho a sensação de que \\
\hline 5 & & eles sabem mais do que eu da matéria e isso me deixa insegura \\
\hline 6 & Carla & é mais quanto ao vocabulário né? \\
\hline 7 & Léa & eu acho que talvez vocabulário a gente consiga dar conta... mas \\
\hline 8 & & aí...como funciona essa palavra específica? não sei \\
\hline 9 & Carla & [entendi] \\
\hline 10 & Enzo & [é é o uso] daquela palavra... eu sei que eles aqui são química \\
\hline 11 & & (.) eles sabem o contexto mas não estão entendendo ○ texto ... \\
\hline 12 & & quando me perguntam uma palavra por exemplo \\
\hline 13 & & eu digo "eu >não sei<... pode ser isso isso ou talvez isso....mas \\
\hline 14 & & pelo que entendi é isso ... tem isso no laboratório de vocês?" aí \\
\hline 15 & & eles "tem um negócio mais ou menos assim assim assim" "e eu \\
\hline 16 & & "a: então deve ser isso"... não tem problema nenhum \\
\hline 17 & Elis & é... NÃO TEM (.) eles nos ajudam \\
\hline 18 & Léa & mas e na prova de aula? \\
\hline 19 & Carla & calma... conversa com a gente... você pode tentar escolher \\
\hline 20 & & um tema que fique mais no meio do caminho (.) acho que você \\
\hline 21 & & está com mais experiência em fazer atividades, né elis? \\
\hline 22 & Elis & é... até tô preparando coisas pra sábado agora... mas é isso aí... \\
\hline 23 & Carla & é de que o material? \\
\hline 24 & Elis & farmácia \\
\hline 25 & Carla & eu adoro aquela turma de farmácia \\
\hline 26 & Elis & é eles são muito legais \\
\hline 27 & & a gente acha que porque é de humanas não vai gostar \\
\hline 28 & & de nada aqui, mas eu acabei me apaixonando \\
\hline 29 & & eu acho muito legal (.) é melhor também porque a gente não tem \\
\hline 30 & & que fazer prova ((rindo)) na escola tinha química e física e tinha \\
\hline 31 & & que fazer prova aí era chato... \\
\hline 32 & Enzo & é: ( (rindo) ) \\
\hline 33 & Elis & aqui não... aqui parece assim... curiosidade de uma revista \\
\hline 34 & Carla & hurrum \\
\hline 35 & Elis & não fica pesado \\
\hline
\end{tabular}




\begin{tabular}{|l|l|l|}
\hline 36 & Carla & conta da aula de sábado \\
\hline 37 & Elis & é de tipos de medicamento (.) fui pesquisando o assunto \\
\hline 38 & & escolhendo os textos... tô fazendo atividades e tentando ligar \\
\hline 39 & & tudo ainda... com a AJUdA da professora \\
\hline 40 & Carla & e ( (virando para léa) ) se precisar... pode contar com a \\
\hline 41 & & nossa ajuda também (.) pode perguntar... ligar... mandar \\
\hline 42 & & whatsapp ... é o que a gente faz normalmente mesmo \\
\hline 43 & Elis & é... a gente faz junto (.) e lembra léa ... \\
\hline 44 & & do que eu tava te falando... nesse sábado vai ter oficina \\
\hline 45 & & sobre materiais... acho que é legal você vir... \\
\hline 46 & Carla & i:sso... exatamente... tenho que até mandar esse e-mail pra vocês \\
\hline 47 & & é com um professor que trabalhou muito tempo aqui e \\
\hline 48 & & ele vai falar sobre a elaboração de materiais de inglês \\
\hline 49 & & para fins Específicos (.) muito bom se você puder vir \\
\hline 50 & Elis & e tem o minicurso também \\
\hline 51 & Léa & o que tem que fazer pra vir? \\
\hline 52 & Carla & vou mandar AGoRA para vocês as informações sobre a oficina \\
\hline 53 & & e como se inscrever no minicurso (.) foi muito bom lembrar isso \\
\hline
\end{tabular}

No excerto 1 da conversa 3, Léa está precisando de acolhimento e nós (eu, Enzo e Elis) procuramos reconfortá-la e construímos conjuntamente a identidade coletiva de membros da comunidade de prática de IFE, imbricada em crenças e emoções. Primeiramente, Léa traz à baila crenças de que o professor de IFE deve dominar as disciplinas específicas (que, no caso do IFRJ, são na área de química e biologia) e de que não pode mostrar saber menos do que seus alunos sobre algo. Tais crenças são depreendidas de eu tenho a sensação de que eles sabem mais do que eu da matéria e isso me deixa insegura (nas linhas 4 e 5) e emergem por meio de afeto - insegurança.

Nesse contexto, Léa tinha completado apenas cinco horas, enquanto Elis e Enzo já tinham passado da metade do estágio. A maior experiência dos últimos, tanto no estágio, como no IFE, pode ser percebida na forma como eles se posicionam (cf. princípio de posicionalidade) como conselheiros para Léa. Além disso, pode-se entender que, por autorização (cf. princípio de relacionalidade), também conferida por essa experiência como membros da comunidade, eles falam por todos nós (professores ou estagiários que estão em formação em inglês e são praticantes de IFE).

Desse 'lugar', eles parecem construir nossas identidades-crenças-emoções de comunidade prática de IFE como parceiros de nossos alunos nas linhas 10 a 17, das quais depreende-se: a) que entendemos nossas identidades em relação aos alunos de forma diferente da de Léa; b) a crença de que não sabemos, ou melhor, não temos que parecer saber tudo e podemos admitir isso para os alunos (como o próprio Enzo faz em seu exemplo quando diz 'eu não sei' e quando ambos afirmam que 'não tem problema'); e c) a crença de que os alunos sabem 
mais sobre o contexto específico, mas também precisam de nós e podemos construir os conhecimentos necessários com eles, o que nos torna parceiros na construção do saber, como exemplificado por Enzo e reforçado por Elis em eles nos ajudam.

Notam-se, ainda, avaliações muito positivas dos licenciandos (cf. Avaliatividade) com gradação muito alta com a repetição da negativa em 'não' e 'nenhum' e a ênfase na fala de Elis (transcrita em caixa alta na linha 17), que sugere que emoções de segurança são constituídas em conjunto com essas crenças e identidades. Assim, Elis e Enzo constroem as nossas crençasidentidades-emoções de parceria em nossas salas de aula de IFE, na qual os conhecimentos são compartilhados: ensinamos e aprendemos muito com nossos alunos em um ambiente em que buscamos o bem-estar de todos.

A pergunta de Léa na linha 18 sobre a prova de aula também parece manter sua construção como estagiária insegura por afeto evocado, fazendo com que Elis e eu nos empenhemos em acalmá-la. Na fala de Léa, também aparece uma crença na supervalorização do instrumento da universidade para a avaliação do estágio, tanto que ela já se mostra preocupada com ele nas primeiras horas cumpridas. Outra crença que emerge em sua pergunta é a de que esse instrumento, ao qual ela chama de 'prova de aula', implica a falta de ajuda, já que, logo depois de Elis confirmar o apoio recebido no estágio (ao dizer que não tem problema não saber tudo, pois eles nos ajudam, na linha 17), Léa parece apresentar a avaliação da regência do final do estágio como uma possível exceção a isso.

A partir daí eu e Elis nos coconstruímos como pares mais competentes $e$ como grupo de apoio por meio da exposição de crenças quanto à colaboração em todos os momentos (como se depreende, por exemplo, de 'conversa com a gente'; 'é isso aí', 'com a AJUDA da professora'; 'se precisar, pode contar com a nossa ajuda também, pode perguntar, ligar, mandar whatsapp, é o que a gente faz normalmente mesmo' e 'é, a gente faz junto', nas linhas 19, 22 e 39 a 43). Nessas orações, é possível também interpretar que há avaliação de julgamento positivo evocado, pelo qual emerge a identidade de companheiros solícitos, com a ideia de grupo reforçada pela repetição de 'nós', 'nossa' e 'a gente'. Essa identidade coletiva é marcada por indexicalidade, mas também por adequação (dentro de relacionalidade, cf. princípios propostos por BUCHOLTZ; HALL, 2005), já que nos construímos 
conjuntamente na crença de que podemos contar uns com os outros, até mesmo na preparação para a regência final.

Questiono se o fato de a regência final ser entendida apenas como uma avaliação é o que agrega a ela à crença de que o estagiário deve passar por esse processo sozinho ou se essa concepção está ligada ao fazer docente em si. A partir do meu posicionamento como praticante de IFE e professora regente em constante aprendizagem com meus pares, acredito que, em ambos os casos (na regência ou no dia-a-dia do docente), não é necessário e talvez nem benéfico, trabalhar de forma solitária.

Nas linhas 26 a 31, Elis retoma a questão das disciplinas específicas que preocupava Léa e se mostra muito mais segura ao assumir a posição de membro experiente na interação, restringindo o uso de modalização para a diminuir a polaridade da gradação e apresentando novas informações (ao invés de se restringir a endossar as dos outros). Seguindo o princípio de relacionalidade, podemos interpretar que Elis se identifica, por adequação, ao 'grupo de humanas', no qual inserem todos os seus interlocutores ali presentes (em a gente acha que porque é de humanas não vai gostar de nada aqui, mas eu acabei me apaixonando, nas linhas 27 e 28). Simultaneamente, ela se constrói como adaptada ao contexto de IFE (identificado como 'aqui') por meio de afeto positivo inscrito com gradação muito alta, de onde também parece emergir a desconstrução da crença que ela teria antes, a de que os profissionais de sua área não encontrariam afinidades com o ambiente do instituto.

Elis também avalia as experiências com as disciplinas específicas por apreciação positiva, se construindo novamente como membro da comunidade de prática e do 'grupo de humanas' a partir do contraste entre o interesse que desenvolveu pelas disciplinas escolares envolvidas no IFE no instituto e os/as sentimentos/crenças que tinha sobre elas na escola: "é melhor também porque a gente não tem que fazer prova, na escola tinha química e física e tinha que fazer prova, aí era chato' e 'parece assim... curiosidade de uma revista, não fica pesado'. Percebe-se que, por meio dessas avaliações, ela se diferencia dos alunos, identificando-se em sua posição naquele contexto como parte do grupo que 'não precisa mais fazer prova' das disciplinas específicas. Além disso, de sua avaliação do 'fazer prova' como chato e da escolha de 'não fica pesado' (que, mesmo na negação, confere, de forma evocada, gradação alta ao possível sofrimento advindo da 
exigência das disciplinas e da avaliação representada por provas), ambas por apreciação, emergem identidades como membro da comunidade de prática como praticante de IFE e não-aluna, embrenhadas em crenças-emoções quanto ao desconforto sobre a cobrança do saber em detrimento da curiosidade e entusiasmo que poderiam ser suscitadas por ele. Em seu vídeo final, ela comenta sua mudança de perspectiva quanto aos seus interesses e essas divisões que acreditava existir das áreas do saber, mostrando-se cada vez mais integrada à nossa comunidade.

Vídeo - Excerto 2 - “Está tudo muito mais ligado do que a gente pensa”
\begin{tabular}{|l|l|}
\hline 18 & a: pela interação com os alunos e com as professoras \\
\hline 19 & porque eu tinha certo receio de ... é: volTAR para o ambiente escolar \\
\hline 20 & mas foi tranquilo foi muito bom foi divertido e também muito enriquecedor \\
\hline 21 & é: : e também pela produção de material \\
\hline 22 & em que eu pude aplicar muita coisa que eu aprendi \\
\hline 23 & >durante a graduação< durante a VIda e também é: : onde eu pude aplicar \\
\hline 24 & a pedagogia crítica que é pra mim e também para os alunos né ... \\
\hline 25 & e: pela interdisciplinaridade que é uma coisa que eu não sei se eu poderia \\
\hline 26 & ter feito em outras escolas... e que ... quando a gente faz a graduação você \\
\hline 27 & acaba ficando um pouco preso na sua especialização ali (.) \\
\hline 28 & então eu acabei me fechando no mundo das letras que é um mundo muito grande \\
\hline 29 & (.) muito rico...mas eu acabei deixando as ciências um pouco de lado ... \\
\hline 30 & >porque eu também tava cansada de fazer escola você faz a vida toda e \\
\hline 31 & fica de saco cheio<(.) fiquei feliz de ter visto é:geografia de no:vo até \\
\hline 32 & química de novo... biologia (.) e:...e: eu percebi que eu não precisava \\
\hline 33 & ter deixado essas coisas de lado ...eu posso fazer letras e ainda não deixar \\
\hline 34 & as exatas de lado (.) está tudo muito mais ligado do que a gente pensa \\
\hline 35 & e é isso... foi um semestre Multo bom... gostei muito do estágio \\
\hline 36 & e: espero que seja uma boa experiência também pros que virão depois de mim. \\
\hline
\end{tabular}

Em sua construção como estagiária e membro da comunidade de prática de IFE, Elis destaca e avalia alguns aspectos do nosso contexto por meio dos quais ela afirma ter 'aprendido muita coisa que quer levar para o resto da vida' (conforme excerto 1 do vídeo): a interação com os alunos e com as professoras, a produção de material e a interdisciplinaridade. Faço minhas as palavras de Elis, quando diz que "está tudo mais ligado do que a gente pensa" e não me refiro somente às diferentes disciplinas escolares, como ela faz no contexto desse vídeo, mas às múltiplas experiências antes e durante o estágio. Por meio de suas avaliações, podemos interpretar que houve a reconstrução de identidadescrenças-emoções de Elis a partir de vivências em nossa comunidade de prática, principalmente quanto à sua percepção sobre como os conhecimentos estão interligados e quanto à valorização dos que ela já possuía. 
O primeiro aspecto analisado em sua fala é a interação com os alunos e com as professoras, que pode ser visto aqui como o acolhimento recebido no estágio, que parece tê-la ajudado a se sentir, se entender e se construir como mais segura do que antes. Tal interpretação tem por base suas escolhas atitudinais: Elis diminui a polaridade da gradação da insegurança que emerge por afeto com relação ao ambiente escolar no passado (pela escolha de 'certo' em porque eu tinha certo receio de ... é: volTAR para o ambiente escolar, na linha 19), para então desfazer a identidade-crença-emoção anteriormente construída pelo uso de recursos de engajamento de contraexpectativa (com o 'mas' seguido de uma perspectiva diferente da apresentada antes) e de apreciação positiva com gradação cada vez mais alta (em mas foi tranquilo foi muito bom foi divertido e também muito enriquecedor, na linha 20). Em outras palavras, o uso dessas marcas avaliativas parece sugerir uma mudança de identidades, crenças e emoções quanto ao contexto escolar a partir do estágio.

O segundo aspecto em voga é a produção de materiais, das linhas 21 a 24 . Aqui, Elis faz conexões entre a aprendizagem no estágio e outros conhecimentos que ela já trazia (em pude aplicar muita coisa que eu aprendi >durante a graduação< durante a VIda, linhas 22 e 23), o que contrasta com sua fala no início do estágio (ver a análise do Excerto 7 da Conversa 1 na seção 6.1.2), quando ela parecia ignorá-los ou não dar seu devido valor. Nas linhas 22 e 23, ela se avalia por julgamento positivo de capacidade construindo-se como colaboradora ativa em nossa comunidade de prática, ao mesmo tempo que se remete à aprendizagem no estágio mostrando-se em alinhamento com o nosso fazer. Desse seu discurso, talvez seja possível inferir a crença no estágio como momento de aplicação de ensinamentos anteriores sendo, nesse ínterim, a compatibilidade encontrada entre a escola e a graduação avaliadas de forma muito positiva (por exemplo em pude aplicar a pedagogia crítica que é pra mim e também para os alunos, na linha 24).

Finalmente, como terceiro aspecto, ela avalia a interdisciplinaridade, destacando-a como algo provavelmente diferenciador em nosso contexto no instituto. Ela se constrói no passado como restrita ao 'mundo das letras' por julgamento negativo (em você acaba ficando um pouco PREso na sua especialização ali, então eu acabei me EECHANDO no mundo das letras que é um mundo muito grande muito rico e mas eu acabei deixando 
as ciências um pouco de lado), sendo a ideia de restrição reforçada pelo uso de 'preso' e 'fechando', que têm a gradação intensificada tanto pelo aumento da entonação de Elis quanto por se tratarem de itens lexicais de mesmo campo semântico. Com vistas a se justificar por sua antiga perspectiva, ela traz a crençaemoção de enfadamento da vida escolar, o que é constituído por recursos avaliativos de afeto negativo (em >porque eu também tava cansada de fazer escola você faz a vida toda e fica de saco cheio<, falado bem rápido, o que pode ser subentendido como algo a ser malvisto por alguns, mas soa como uma espécie de confissão aos seus pares ${ }^{47}$ que talvez ela julgue que compartilhem da mesma crença-emoção), pelos quais emerge a identidade de aluna entediada. Portanto, vemos aqui novamente que ela resgata identidades, crenças e emoções negativas do passado ligadas a experiências escolares para contrastar com as suas perspectivas presentes, que sugerem sua reconstrução a partir das participações no estágio. Assim, ela se reformula como satisfeita $e$ integrada ao contexto escolar por meio do IFE, construindo-se por afeto positivo (em fiquei feliz de ter visto é: geografia de no:vo até química de novo... biologia). Já se mostrando adaptada como membro da comunidade de prática, Elis se renova ao refletir sobre o que acreditava/sentia sobre as diferentes disciplinas (antes vistas por ela como estanques) em alinhamento às nossas crenças, se mostrando mais receptiva ao se entender em diálogo com outros conhecimentos (em eu percebi que eu não precisava ter deixado essas coisas de lado ...eu posso fazer letras e ainda não deixar as exatas de lado, está tudo muito mais ligado do que a gente pensa, linhas 32 a 36).

Ela encerra o vídeo avaliando três vezes o estágio com gradação muito alta nas linhas 35 e 36: duas vezes com apreciação positiva, referindo-se ao tempo conosco como MUITO bom e depois como uma boa experiência que ela deseja para outros estagiários; e outra por afeto (em gostei muito do estágio), que assevera ainda mais essa perspectiva ao mostrar claramente o envolvimento emocional da estagiária. Nessas avaliações, emergem as identidades-emoções de estagiária experiente e satisfeita com o período de pré-serviço e talvez a crença de que ele é um dos alicerces de sua carreira docente. Essa possibilidade de leitura se explica pela conexão de Elis entre ter

\footnotetext{
${ }^{47}$ Lembro que o vídeo foi gravado para ser exibido a outros licenciandos.
} 
(ou não) 'uma boa experiência' e seu processo decisório de tornar-se professora, o que foi mencionado no diário 1 e é reconstruído no memorial (onde essas escolhas lexicogramaticais são repetidas três vezes).

Também na porção a ser analisada do memorial de Elis ${ }^{48}$, ela nos conduz por sua caminhada identitária durante sua vivência no estágio como membro da nossa comunidade de prática de IFE. Como explicado no capítulo 5 , após ter terminado o estágio, Elis produziu seu texto para ser entregue como um dos trabalhos finais da disciplina de Prática de Ensino na universidade e, a meu pedido, também me enviou uma cópia. Elis inicia seu memorial trazendo uma reflexão sobre o estágio como um todo, destacando a experiência conosco como essencial em suas reconstruções identitárias.

Memorial de estágio - Excerto 1
\begin{tabular}{|r|l|}
\hline 1 & Minha experiência no estágio foi a parte mais significativa \\
\hline 2 & da reta final da minha graduação. \\
\hline 3 & Amadureci muito nesses semestres \\
\hline 4 & e o estágio foi essencial nesse processo que, de forma geral, \\
\hline 5 & foi extremamente positivo, útil e recompensador. \\
\hline 6 & Estagiei em três escolas e acompanhei várias turmas e professoras, \\
\hline 7 & conhecendo pessoas que contribuíram para minha transição \\
\hline 8 & não só de estagiária para professora, \\
\hline 9 & mas também de adolescente para adulta. \\
\hline
\end{tabular}

Nesse excerto, o estágio é avaliado por apreciação positiva com gradação muito alta em todas as subcategorias ${ }^{49}$ (reação, composição e valoração em essencial, extremamente positivo, útil e recompensador, linhas 1 a 5) mostrando como sua perspectiva sobre o período se expandiu em relação à sua ideia inicial restrita de estágio como 'teste' (ver transcrição do vídeo e as respostas das questões iniciais). Ela também se refere a ele como 'parte da graduação' e não algo estanque (em a parte mais significativa da reta final da graduação), o que sugere que ela se constrói interligando conhecimentos da universidade e da escola. Além disso, Elis dá grande ênfase à noção de estágio como processo de reconstruções identitárias pessoais e profissionais, como transição (linha 7), a partir da qual ela se avalia por julgamento positivo (em Amadureci muito, linha 3). Todas essas escolhas a constroem como pessoa/profissional em processo tendo o estágio como uma das principais

\footnotetext{
48 Apenas a parte do memorial de Elis que concerne o estágio no IFRJ será contemplada neste estudo (ver mais detalhes no capítulo 5).

${ }^{49}$ Segundo Martin e White (2005), a apreciação se divide em composição (que são os sentimentos que dizem respeito à organização, à elaboração e à forma pela qual as coisas e objetos se mostram), reação (se refere às emoções que as coisas provocam nas pessoas) e valoração (que está ligada à significação social do item avaliado).
} 
estradas tomadas. Assim, por indexicalidade, ela se identifica, naquele momento da caminhada, já no final do estágio, como professora e adulta, relegando ao passado as identidades de estagiária e adolescente, pelas quais ela já não mais se reconhece. Logo depois, no Excerto 2, ela começa a recuperar alguns dos momentos mais marcantes dessa estrada que ela seguiu enquanto esteve conosco no IFRJ, trazendo também reflexões sobre como se entendia antes do início do período de pré-serviço.

Memorial de estágio - Excerto 2
\begin{tabular}{|r|l|}
\hline 10 & O primeiro estágio que fiz foi com as turmas de inglês no instituto. \\
\hline 11 & Por não ter tido uma boa experiência na minha formação escolar, \\
\hline 12 & evitei a disciplina Prática de Ensino por alguns semestres \\
\hline 13 & porque tinha medo de voltar a uma escola. \\
\hline 14 & Mas cheguei a um ponto da graduação \\
\hline 15 & em que iniciar essa disciplina era inevitável, então me inscrevi. \\
\hline 16 & Nos meses anteriores, tive muita ansiedade e cheguei a ter pesadelos. \\
\hline 17 & Tinha medo de como os alunos me tratariam. \\
\hline 18 & Assim, fui para o IFRJ sem saber o que aconteceria. \\
\hline 19 & O primeiro momento foi um pouco desconcertante \\
\hline 20 & porque nunca tinha ouvido falar sobre inglês pra fins específicos antes. \\
\hline 21 & Minha prioridade em sala de aula é conseguir ajudar os alunos \\
\hline 22 & e por isso fiquei preocupada de não poder fazê-lo \\
\hline 23 & por minha falta de conhecimento na área deles. As turmas que \\
\hline 24 & acompanhei foram de bioquímica, alimentos, farmácia e meio-ambiente. \\
\hline 25 & A ciência era algo tão distante da minha realidade \\
\hline 26 & que meu primeiro pensamento é que ficaria perdida \\
\hline 27 & em meio a tantos termos técnicos e assuntos que são difíceis pra mim. \\
\hline
\end{tabular}

No início do Excerto 2, Elis utiliza recursos avaliativos de afeto de insegurança inscrito e evocado com gradação alta das linhas 11 a 18 (como em por não ter tido uma boa experiência, muita ansiedade, medo, cheguei a ter pesadelos, fui para $\bigcirc$ IFRJ sem saber $\bigcirc$ que aconteceria), dos quais emergem identidades-crenças-emoções negativas quanto à docência e ao estágio antes de iniciá-lo, que a constroem como uma pessoa totalmente apavorada/insegura quanto ao ambiente escolar no passado. Ao que parece, nessas avaliações sobre aquela etapa de sua vida, emergem crenças (misturadas a emoções de temor) mais centrais, que, como afirma Rokeach (1968, apud BARCELOS, 2007), são mais interconectadas com outras e profundamente relacionadas com as identidades, pois derivam de nossa experiência direta. Sabendo que há uma resistência maior para desconstruir crenças/sentimentos como esses, que, como relata Elis, foram muito nocivos para sua qualidade de vida na escola e em sua trajetória para tornar-se professora, acredito ser necessário fomentar momentos para sua reflexão e possível reformulação. 
Podemos perceber que tal reformulação está presente na escrita de Elis enquanto ela nos encaminha por seus passos em nossa comunidade de prática. $\mathrm{Na}$ linha 19, lemos que o contato inaugural com o ensino de IFE é avaliado, por apreciação negativa, como desconcertante e Elis atribui esse impacto à falta total de qualquer menção à abordagem até aquele momento de sua formação (linha 20), questão discutida nesta tese na seção 2.1.4. Continuando sua explicação para a apreciação, Elis traz outras avaliações, das quais emergem identidades arraigadas às suas crenças e emoções negativas sobre si mesma e sobre o ensino de IFE.

Primeiramente, ela retoma as identidades de estagiária auxiliadora dos alunos, insegura e inexperiente, que emergem por afeto negativo (em fiquei preocupada de não poder fazê-lo, referindo-se a ajudar os alunos). A elas se soma a de ainda não pertencente ao nosso contexto, construída por julgamento negativo quanto à sua capacidade em atuar em nossas aulas (em por minha falta de conhecimento na área deles e meu primeiro pensamento é que ficaria perdida) e por apreciação negativa do IFE (em A ciência era algo tão distante da minha realidade e termos técnicos e assuntos que são difíceis pra mim). Notamos que, juntamente a essas identidades, que são atreladas a emoções negativas, principalmente de insegurança, parecem emergir também crenças quanto ao preparo do professor de IFE e a importância dada ao conhecimento das disciplinas específicas e do vocabulário técnico; quanto ao distanciamento das ciências para o profissional de Letras (também mencionada em outros momentos, como no vídeo, por exemplo); e também quanto ao possível isolamento e desamparo no contexto de ensino de IFE. No entanto, parece que tudo isso é citado por Elis como identidades-crençasemoções do passado, que são desconstruídas a partir de sua inserção em nossa comunidade de prática, como pode ser visto no excerto 3 de seu memorial:

Memorial de estágio - Excerto 3

\begin{tabular}{|l|l|}
\hline 28 & Mas rapidamente percebi que não seria assim. \\
\hline 29 & Conseguia entender o que se passava nas aulas \\
\hline 30 & e apesar de não ter muito contato com os alunos, \\
\hline 31 & pude ajudá-los quando precisavam. \\
\hline 32 & Aos poucos, fui me interessando mais e mais pelo IFE \\
\hline 33 & Como não aprendi inglês de uma forma tradicional, \\
\hline 34 & mas de forma bastante autônoma, \\
\hline 35 & me adaptei facilmente à abordagem porque \\
\hline 36 & envolve a pesquisa de temas interessantes \\
\hline 37 & (e, consequentemente, temas que incitam pensamento crítico); \\
\hline 38 & retrata a gramática de forma sutil, não sendo o foco principal da aula; \\
\hline 39 & valoriza o conhecimento dos alunos; \\
\hline 40 & torna o processo de ensino-aprendizagem mais dinâmico e colaborativo. \\
\hline
\end{tabular}


Nesse excerto do memorial, Elis desconstrói suas avaliações negativas usando recursos de engajamento de contra-expectativa (em Mas rapidamente percebi que não seria assim, linha 28) e se reformula como praticante de IFE, atenta e capaz avaliando a si mesma por meio de julgamento positivo (em rapidamente percebi, conseguia entender o que se passava nas aulas e pude ajudá-los quando precisavam). É possível que essa percepção tenha sido promovida pela inserção de Elis em nossa comunidade de prática, com a qual ela se identifica principalmente por adequação (cf. princípios propostos por BUCHOLTZ; HALL, 2005) nas linhas 32 a 40. Para tanto, ela se constrói como aprendiz autônoma também por julgamento positivo (em não aprendi inglês de uma forma tradicional, mas de forma bastante autônoma, linhas 33 e 34) e faz conexões entre a forma como ela aprendeu inglês e o fazer na abordagem.

Ao arrolar as razões para a sua 'fácil adaptação' (linha 35) ao IFE, além de mostrar como compartilha nossos preceitos, o que a identifica, por indexicalidade (cf. princípios propostos por BUCHOLTZ; HALL, 2005), como membro de nossa comunidade de prática, Elis põe muito de si, seus sentimentos e de suas crenças. Assim, podemos inferir que, para nós (incluindo Elis), o professor de inglês, deveria se envolver na pesquisa dos temas que despertam o interesse e incitem o pensamento crítico (linhas 36 e 37), tirar o foco da gramática (linha 38), fomentar a participação dos alunos e valorizar seu conhecimento para um ensinoaprendizagem mais dinâmico e colaborativo (linha 40). A questão da criação própria do material didático é o próximo tópico sob o escrutínio da licencianda, que o expande no Excerto 4.

Memorial de estágio - Excerto 4

\begin{tabular}{|l|l|}
\hline 41 & O primeiro estágio que fiz foi com as turmas de inglês no instituto. \\
\hline 42 & Aprendi, também, que nas aulas de IFE não se usa livro didático \\
\hline 43 & e sim um material criado pelas próprias professoras. \\
\hline 44 & Quando produzi materiais para minhas coparticipações, \\
\hline 45 & percebi que era um exercício muito criativo e complexo. \\
\hline 46 & Gostaria que houvesse um espaço maior \\
\hline 47 & pra produção de materiais na faculdade \\
\hline 48 & (poderia ser uma disciplina optativa) \\
\hline 49 & porque é algo essencial nessa profissão. \\
\hline 50 & Me diverti fazendo o material \\
\hline 51 & para minha coparticipação na aula sobre perfumes na turma de Farmácia \\
\hline 52 & e também fiquei feliz quando ajudei a professora \\
\hline 53 & a elaborar uma prova para a turma de Bioquímica. \\
\hline 54 & Acredito que todo material tenha seu valor, \\
\hline 55 & mas me identifiquei com esse tipo de material do IFE \\
\hline 56 & de uma forma que não aconteceu \\
\hline 57 & com nenhuma outra metodologia/abordagem até então. \\
\hline
\end{tabular}


Ao discorrer de forma categórica, por recursos de engajamento de contração dialógica, sobre a produção de materiais, Elis se posiciona como estagiária/ membro experiente de nossa comunidade, conhecedora de nossas práticas (linhas 41 e 45) e não mais cheia de dúvidas quanto à escolha pela docência como tinha se mostrado na Conversa 1. Dessa posição, Elis aponta o conhecimento sobre a elaboração de materiais didáticos como essencial para a profissão docente (linha 49), apreciação positiva com gradação muito alta da qual emerge a crença de nossa comunidade sobre a importância dessa habilidade, o que é expandido pela estagiária ao refletir sobre a necessidade de uma disciplina, mesmo que optativa, a ser contemplada na faculdade.

Elis também se mostra como participante ativa, usando várias escolhas que mostram avaliações de julgamento positivo de si (como, por exemplo, em produzi materiais para minhas coparticipações e ajudei a professora a elaborar uma prova e até mesmo na repetição da nominalização 'minha coparticipação' e 'minhas coparticipações', nas linhas 44 e 51). Pode-se também dizer que, de sua escolha em avaliar a produção de materiais como 'um exercício muito criativo e complexo' seguida de tantas menções à sua prática na elaboração dos mesmos no estágio também emergem identidades de praticante de IFE, capaz, criativa e útil. Além disso, sua participação, que ela parece fazer questão de citar, é construída com base em afeto explícito de felicidade e satisfação (linhas 50 a 57): Me diverti fazendo - material, fiquei feliz quando ajudei a professora e me identifiquei com esse tipo de material do IFE de uma forma que não aconteceu com nenhuma outra metodologia/abordagem até então. Dessas seleções avaliativas, surgem identidades-crenças-emoções de bem-estar que, dessa vez, não advêm de outras pessoas, mas de seu próprio processo de 'fazer' e 'ajudar a elaborar' e 'se identificar'. Em vista disso, ela se constitui, naquele momento de sua caminhada identitária, como profundamente conectada e adaptada à nossa comunidade de prática por adequação (cf. princípio de relacionalidade em BUCHOLTZ; HALL, 2005).

É possível perceber que Elis se mostra mais segura em suas asserções sobre a docência em comparação à forma que se expressou nas respostas às questões iniciais analisadas nesta tese, onde usava metáforas gramaticais interpessoais (como o uso de imagino que, nas linhas 2 e 6), o que sugere sua incerteza e até certa fragilidade então. No entanto, é imprescindível sublinhar que 
a identidade construída nesses exemplos, como alguém mais confiante $e$ assertiva, pode ser temporária e local, seguindo o princípio de posicionalidade (BUCHOLTZ; HALL, 2005). Desse modo, Elis pode se mostrar menos insegura nesse contexto situacional e não necessariamente se comportará da mesma forma em outra ocasião qualquer. Essas escolhas da estagiária podem ter sido feitas, dentre muitas outras razões, porque: 1. ela estava escrevendo seu memorial de estágio, em que deveria assumir uma postura crítica sobre suas experiências e exibir o que fez durante esse período, cumprindo o que se espera na produção desse gênero discursivo; 2. o assunto (o ensino de IFE) era de seu domínio naquele momento e, ao participar da nossa comunidade de prática, ela parece ter assumido a posição de membro do grupo e como tal, buscava apoiar a abordagem e, ao mesmo tempo, tinha as credenciais (cf. princípio de relacionalidade - autorização) para apontar a necessidade da disciplina na licenciatura; e 3. ela levou em consideração o que conhecia sobre sua leitora (a professora de Prática de Ensino), que também foi estagiária no instituto e poderia talvez compartilhar a mesma opinião. Portanto, as identidades que ela assume são dependentes desse contexto específico e suas peculiaridades. Observemos como ela reitera sua afinidade com nossa comunidade por meio da avaliação da sua relação com os participantes do estágio.

\section{Memorial de estágio - Excerto 5}

\begin{tabular}{|r|l|}
\hline 58 & Sobre as professoras, tive um relacionamento muito bom com elas. \\
\hline 59 & Acompanhava a prof. ${ }^{a}$ Carla nas quintas-feiras e a prof. ${ }^{a}$ Maria nos sábados. \\
\hline 60 & Ambas são profissionais muito competentes e humanas, \\
\hline 61 & o que foi importante presenciar \\
\hline 62 & já que foram minha primeira referência na atividade docente em si. \\
\hline 63 & Além de terem me ensinado bastante sobre o IFE \\
\hline 64 & e educação em geral, também me ofereceram apoio e carinho \\
\hline 65 & e fizeram eu me sentir acolhida. \\
\hline
\end{tabular}

A relação de Elis com suas professoras regentes (eu e Maria) é o tema do quinto excerto, que é desenvolvido com seleções avaliativas que a constroem como estagiária e aprendiz acolhida na comunidade de prática e das quais parecem emergir crenças e emoções sobre o trabalho dos professores da escola e a experiência do estágio. Inicialmente, é possível entender, pelos princípios de indexicalidade e posicionalidade, que Elis se insere em seu memorial como estagiária ao se descrever naquele contexto (acompanhando as professoras e sendo ensinada nas linhas 59 e 63, por exemplo), ao mesmo tempo que se refere a mim e a Maria como professoras, profissionais e uma referência para ela (linhas 58, 60 e 62), que marcam algumas das relações de poder entre nós. 
No entanto, ao invés de optar por construir sua perspectiva pelo nosso afastamento nas relações interpessoais, a licencianda frisa, por intermédio de julgamento positivo com graduação alta, não somente o conhecimento e as habilidade geralmente ligadas ao fazer docente, mas principalmente, a dimensão humana e a construção de laços. Sob o olhar de Elis, não só a competência (linha 60) e o 'ensinar sobre IFE e educação geral' (linhas 63 e 64) mereceram menção, mas também a 'humanidade' (linha 60) e o fato de termos oferecido apoio e carinho e feito com que se sentisse acolhida (linhas 64 e 65). Inegável é também a carga emocional nesse trecho, construída por meio de afeto, por vezes evocado, de satisfação e de segurança.

Desse modo, pode-se interpretar que emergem de seu discurso identidades de estagiária e aprendiz acolhida naquele contexto, entrelaçadas a crençasemoções de que 1. o suporte emocional e o acolhimento no estágio são muito importantes no processo de formação docente; 2. a forma como os professores conduzem as relações interpessoais não só com seus alunos, mas também com os estagiários, faz parte da aprendizagem no estágio; e 3. o professor regente não é apenas alguém a ser observado, analisado, criticado ou imitado, mas pode ser o par mais competente que 'oferece carinho e apoio'. Essa proximidade entre a estagiária e sua professora regente parece ser o foco no Excerto 2 da Conversa 3 , quando Elis e eu conversamos sobre como ela e Maria elaboravam materiais didáticos.

Conversa 3 - Excerto 2 - "a gente faz um pouquinho de tudo"

\begin{tabular}{|r|l|l|}
\hline 1 & Carla & mas como é que vocês fazem o material você e maria? vocês começam \\
\hline 2 & & do zero e aí escolhem... escolhem... \\
\hline 3 & Elis & a: a gente pesquisa textos na internet, baixa vídeos \\
\hline 4 & & às vezes a gente até tem uma ideia que muda tudo \\
\hline 5 & & tanto que na aula de meio-ambiente >tava falando pra ela< a gente \\
\hline 7 & & tava na dúvida pra fazer alguma coisa pra turma de meio-ambiente \\
\hline 8 & & e ela ia falar sobre outro assunto e aí ela me deixou trocar \\
\hline 9 & Carla & hurrum eu falei "porque que a gente não fala sobre outra coisa?" \\
\hline 10 & Elis & e aí virou uma aula completamente diferente muito mais voltada pra \\
\hline 11 & & nossa realidade praquela turma ... a especificidade \\
\hline 12 & Carla & si:m mas com os temas... lidando com os temas em si é: como é que \\
\hline 13 & & como é ... vocês... como é que vocês estão fazendo assim é: com \\
\hline 14 & & o foco? fica mais no vocabulário? ou mas em reading strategies o:u \\
\hline 15 & Elis & a gente faz um pouquinho de tudo assim ... procura não focar demais \\
\hline 16 & & em uma coisa em um aspecto (.)a gente tenta fazer é: aí tenta achar \\
\hline 17 & & algum motivo na internet com o tema e vocabulário que é importante \\
\hline 18 & & pra eles (.) algumas palavras novas \\
\hline 19 & Carla & e aí você faz atividade com vocabulário ou não? \\
\hline 20 & Elis & geralmente fica: (.) por exemplo eu fiz três atividades... aí uma \\
\hline 21 & & vai ser de discussão sobre o tema outra do gênero outra sobre o \\
\hline 22 & & vocabulário específico da área deles... perguntas diferentes assim \\
\hline 23 & & trabalha todos esses aspectos \\
\hline
\end{tabular}


No Excerto 2 da Conversa 3, Elis usa continuamente o 'a gente' (nas linhas $3,4,5,8,15$ e 16) para se referir a si mesma como parte de um grupo formado por ela, Maria e talvez outros estagiários, o que parece identificá-la, juntamente com todas as ações conjuntas dessas pessoas, a partir dos princípios de indexicalidade e relacionalidade - adequação, como elaboradora de materiais didáticos parte do grupo de estágio. As ações desse grupo são sempre avaliadas por julgamento positivo quanto à capacidade de preparar as aulas seguindo as premissas da nossa abordagem, atentos às necessidades da turma (linhas 4 a 11) e procurando não focalizar apenas um aspecto (como em a gente faz um pouquinho de tudo assim ... procura não focar demais em uma coisa em um aspecto e trabalha todos esses aspectos, linhas 15, 16 e 23). Dessas avaliações, permeadas por crenças sobre como proceder ao planejar aulas, emerge a identidade de membro da comunidade de prática de IFE. A identidade-crença-emoção de acolhida nessa comunidade também parece ser realçada nessas linhas, o que pode ser interpretado pelo uso de julgamento positivo do comportamento da regente (que está implícito em ela me deixou trocar porque eu falei "porque que a gente não fala sobre outra coisa?", nas linhas 7 e 8) e dos recursos de apreciação positiva com gradação muito alta sobre a aula, que foi fruto da ideia dada por Elis (em e aí virou uma aula completamente diferente muito mais voltada pra nossa realidade praquela turma ... a especificidade, linhas 10 e 11). Com essas escolhas, ela não só se constrói como colaboradora ativa da comunidade, mas também como estagiária, que precisa da permissão de sua professora regente para intervir.

De qualquer forma, Elis se mostra mais segura e integrada, o que emerge de todas as avaliações positivas de si (sozinha ou como parte do grupo), e acredito que atitudes como a receptividade de Maria às ideias dos estagiários e a abertura dada a eles para a participação em diferentes momentos, pode ter sido muito importante para essa reconstrução da licencianda. Essa visão se apoia também na referência ao momento que Elis narrou esse episódio entre ela e Maria para Léa na linha 5 (em >tava falando pra ela<), o que aconteceu um pouco antes do início da gravação, quando estávamos tentando tranquilizar a nova colega que estava chegando no IFRJ. Assim, a relação de parceria com sua regente parece ter sido usada como exemplo para confortar a colega em seus momentos iniciais de estágio, no qual os licenciandos ainda não sabem 'onde se encaixam', como 
Elis cita na Conversa 4. Em seguida, retorno ao memorial de estágio, no qual ela ainda se debruça sobre a criação de vínculos em nosso contexto, mas agora com foco nos alunos.

Memorial de estágio - Excerto 6

\begin{tabular}{|l|l|}
\hline 66 & Não tive um relacionamento tão próximo com os alunos \\
\hline 67 & quanto gostaria de ter tido, mas não acho que tenha sido um problema. \\
\hline 68 & Estava (e ainda estou) no começo da minha carreira \\
\hline 69 & e sei que tenho muito a melhorar. \\
\hline 70 & Ainda assim, os alunos foram simpáticos durante minhas coparticipações \\
\hline 71 & e fiquei emocionada com o apoio deles. \\
\hline
\end{tabular}

A preocupação de Elis quanto à sua conexão com os alunos é retomada no Excerto 6 e a sua insatisfação é marcada discursivamente com afeto nas linhas 66 e 67 (em Não tive um relacionamento tão próximo com os alunos quanto gostaria de ter tido). Contudo, ela faz uma ponderação, usando modalização para quebrar a intensidade de sua avaliação ao dizer 'não acho que tenha sido um problema' e dá uma espécie de justificativa para a não completude de suas expectativas e/ou crenças no que concerne a relação entre professores e alunos. De sua proposição, emerge a construção de sua identidade como professora iniciante e em processo-em Estava (e ainda estou) no começo da minha carreira e sei que tenho muito a melhorar. Percebemos, porém, que, apesar de se identificar como uma novata, ela se insere como seguidora da carreira docente e já não parece ter mais dúvidas quanto à continuação na profissão.

É notável como as crenças e emoções integram e dão sustentação à trajetória identitária de Elis, sendo que elas não vão simplesmente se acumulando: algumas surgiram, outras mudaram e/ou se enraizaram ainda mais no decorrer das interações e participações no contexto do estágio. Podemos interpretar, por exemplo, que algumas concepções negativas quanto à docência, realizadas no texto por meio de escolhas dentro do subsistema de atitude, foram trazidas no memorial para mostrar como a licencianda se reformulou durante a sua caminhada. Quanto a esse aspecto, destaco suas construções como professora em início de carreira e do próprio estágio como parte de seu processo de tornarse docente (linhas 8 e 68 do memorial) que se diferencia muito da forma que se referia a si mesma e ao período de pré-serviço nas respostas às questões iniciais.

Em contraste, outras crenças e emoções parecem ter se arraigado, como as encontradas em sua perspectiva de que é parte essencial da profissão docente e do estágio estabelecer um relacionamento de proximidade e confiança com 
alunos, como pode ser observado novamente nas linhas 66 e 67 do Excerto 6 do memorial. Uma interpretação complementar a essa seria a de que Elis constrói, nessas linhas, a identidade-crença-emoção de estagiária tomando como premissa que essa posição implica em ser uma pessoa 'de fora' em busca de integração e acolhimento, tentando 'se encaixar' em nosso contexto (como discutido na análise da Conversa 4). Essa leitura também pode ser proporcionada quando Elis lança mão de recursos de julgamento positivo para avaliar os alunos e se atém apenas ao comportamento deles em relação a ela (em foram simpáticos durante minhas coparticipações, na linha 70), sendo essas escolhas atreladas ao afeto em fiquei emocionada com o apoio deles (linha 71). Passemos agora aos trechos 8, 9 e 10, que versam sobre a regência, considerado o ápice do processo de estágio pelos licenciandos.

Memorial de estágio - Excerto 7
\begin{tabular}{|r|l|}
\hline 72 & Participei mais das aulas da turma de Farmácia, \\
\hline 73 & já que faria minha regência lá. \\
\hline 74 & Me esforcei bastante para fazer o material da regência \\
\hline 75 & porque fiz uma longa pesquisa, \\
\hline 76 & mas apesar de trabalhoso não foi um processo \\
\hline 77 & que fez com que eu me sentisse desconfortável ou nervosa. Como disse \\
\hline 79 & anteriormente, me identifiquei com a abordagem e as professoras, \\
\hline 80 & então apesar do nervosismo natural que a regência traz, \\
\hline
\end{tabular}

Nesse excerto, pode-se notar que Elis menciona aspectos essenciais das práticas de nossa comunidade na preparação de sua regência, como o contato com a turma (linhas 72 e 73), a elaboração do material e a pesquisa (linhas 74 a 76) e chama o IFE de 'abordagem' (linha 78), o que, seguindo o princípio de indexicalidade, a identificam, nesse contexto, como estagiária praticante de IFE. Soma-se a isso o destaque que Elis dá à sua dedicação apesar da dificuldade, que a constrói como esforçada, comprometida e resiliente, o que emerge por meio de julgamento positivo em me esforcei bastante porque fiz uma longa pesquisa e apesar do nervosismo natural que a regência traz, consegui compreender o que precisava fazer e como fazer (nas linhas $74,75,79$ e 80). A ideia de que ela trabalha arduamente, enfrenta seus temores, continua firme e não desiste apesar de tudo é asseverada pelas opções lexicogramaticais com gradação muito alta como 'esforcei bastante', 'longa' e da apreciação do processo como 'trabalhoso'. Nessas escolhas, notamos que Elis parece se construir como alguém mais seguro do que antes, identidadecrença-emoção, que também surge em sua avaliação por afeto positivo em não 
foi um processo que fez com que eu me sentisse desconfortável ou nervosa, na linha 77.

Percebemos que há uma mistura de emoções e identidades de segurança e insegurança nas construções de Elis no Excerto 7 do memorial, o que pode ser compreendido pelo princípio de parcialidade: o fato de ela se descrever como 'não nervosa' (linha 77) para depois admitir o nervosismo (linha 79) exemplifica como as constituições identitárias são extremamente complexas e oscilantes. No entanto, pode-se considerar também que a menção ao nervosismo da linha 79 serve como pano de fundo para sua construção como alguém capaz, pois faz parte do recurso de engajamento de contraexpectativa em apesar do nervosismo natural que a regência traz (oração na qual também há a 'naturalização' da insegurança), que é usado para introduzir seu julgamento positivo de si em consegui compreender.

Essas identidades-crenças-emoções (de estagiária capaz e mais segura) são desenvolvidas em seu texto como consequência de ter se identificado com a abordagem e as professoras (linhas 78 a 80), ou seja, emerge da sua construção como membro da nossa comunidade de prática. Esse senso de pertencimento (como mencionado por MURPHEY; PROBER; GONZALES, 2010) e a confiança de que encontraria em seus pares colaboração e o apoio emocional (defendidos por MAHN; JOHN-STEINER, 2002) parecem ter sido muito importantes na trajetória identitária de Elis, como exemplificado em seu diário sobre a regência, momento que ela nomeia como 'prova-aula'. Naquele texto, ela muitas vezes se constrói como estagiária insegura por meio de afeto (como em fiquei receosa porque tinha medo de não conseguir calcular o tempo adequado para cada passo e acabar passando do horário estipulado) e julgamento de capacidade (como em tenho dificuldade em nomear as coisas, achei que esse tema simplesmente não fosse pra mim e tenho dificuldade de falar em público) muito negativos, mas destaca como as relações com outras pessoas a ajudaram a seguir em frente.

Em seguida, ela desabafa, em seu diário, como foi longa sua jornada para se preparar para a etapa da regência e como ela interagiu com diferentes fontes, o que a caracteriza como praticante de IFE: além de sua pesquisa sobre as características da turma e sobre o tema específico na internet e em livros, ela conversou com uma amiga estudante de Saúde Pública sobre o tema da aula e possíveis textos a serem usados; aproveitou a oficina sobre materiais didáticos 
dada pelo professor convidado no IFRJ e depois debateu com ele sobre tipos de interação dos alunos e exercícios; e discutiu suas ideias comigo, com Maria e com a professora de Prática de Ensino, sempre buscando elaborar a aula de forma a promover a reflexão crítica dos alunos sobre o tema. Sua perspectiva sobre si mesma parece ter se transformado ao longo dessas interações e, apesar de se mostrar inicialmente insegura, vemos, na conclusão do segundo diário, como ela assume a posição de professora de IFE e membro de nossa comunidade, destacando vários aspectos que são caros para nós (como, por exemplo, a pesquisa, a elaboração do próprio material e o estudo do assunto sob diferentes pontos de vista, a atenção às peculiaridades e necessidades da turma, a reflexão crítica e a ética):

\section{Diário sobre a Regência - Excerto 3}

\begin{tabular}{|l|l|}
\hline 201 & Em relação ao item Planejamento escrito da aula, \\
\hline 202 & houve um esforço real da minha parte \\
\hline 203 & para trazer um material de qualidade para os alunos \\
\hline 204 & e estudar um assunto que antes era totalmente desconhecido pra mim \\
\hline 205 & com boa vontade e mente aberta. \\
\hline 206 & Hoje, teria começado minha pesquisa mais cedo \\
\hline 207 & e procuraria mais fontes; \\
\hline 208 & pretendo ser uma pessoa mais organizada nesse sentido daqui em diante. \\
\hline 210 & Também considerei minha nota justa em relação ao item Desenvolvimento. \\
\hline 211 & sem subestimá-los ou usar algo que estivesse fora de sua realidade \\
\hline 212 & e isso contribuiu para o funcionamento da aula. \\
\hline 213 & Também tentei estar presente entre os alunos e mostrar-me solícita. \\
\hline 214 & Durante o debate no final da aula, fiz o que pude para validar todas as \\
\hline 215 & vozes pois acredito que o importante não é necessariamente concordarmos \\
\hline 216 & mas sim refletir de forma crítica e respeitosa. \\
\hline 217 & Como futura professora, quero incentivar os alunos a fazerem isso \\
\hline 218 & como parte da minha prática docente. \\
\hline 219 & A prova-aula foi um momento muito bonito da minha formação. \\
\hline 220 & Considerando o fato de que foi a primeira aula que eu dei na vida, \\
\hline 221 & acho que as coisas foram até melhor do que eu esperava. \\
\hline 222 & Pensei que fosse ficar muito nervosa, mas na hora não fiquei. \\
\hline 223 & Foi uma aula agradável e acho que consegui fazer um trabalho \\
\hline 224 & que resumiu o estágio como um todo. \\
\hline
\end{tabular}

Na parte final do Diário sobre a Regência, vemos uma grande recorrência a escolhas avaliativas de julgamento, em sua maioria positivo (dois dos muitos exemplos são: houve um esforço real da minha parte para trazer um material de qualidade para os alunos e estudar um assunto que antes era totalmente desconhecido pra mim com boa vontade e mente aberta; e tentei estar presente entre os alunos e mostrar-me solícita nas linhas 202 a 205 e 213), para falar de si mesma. Essas avaliações a constroem como pesquisadora, elaboradora de materiais, colaboradora, 
dinâmica, atenta aos alunos, ética e preocupada em promover o pensamento crítico, dentre outras identidades-crenças-emoções compartilhadas pela nossa comunidade de prática (de forma similar ao que pode ser observado na análise do Excerto 3 do memorial).

Mesmo quando ela cogita mudanças em seu comportamento, como em Hoje, teria começado minha pesquisa mais cedo e procuraria mais fontes; pretendo ser uma pessoa mais organizada nesse sentido daqui em diante, suas avaliações, também dentro dos recursos de julgamento podem ser interpretadas como positivas visto que elas a constituem como estagiária/professora autocrítica, em processo, buscando melhorar. Também chama a atenção a recorrência da licencianda em citar seu posicionamento ético, inclusivo e reflexivo em diferentes momentos, tanto no relacionamento com os alunos (como no julgamento positivo em fiz o que pude para validar todas as vozes pois acredito que o importante não é necessariamente concordarmos, mas sim refletir de forma crítica e respeitosa), nas escolhas para a elaboração do material, como na menção à sua 'mente aberta' (na linha 205) e no Excerto 1 de seu segundo diário.

Diário sobre a Regência - Excerto 1

\begin{tabular}{|l|l|}
\hline 107 & Como estudantes de Farmácia, acredito que a visão dos alunos em relação \\
\hline 108 & a essas questões tenha um grande peso, seja para a legalização ou \\
\hline 109 & proibição do uso de qualquer substância de forma legal. \\
\hline 110 & Acredito, até, que essa discussão poderia ser feita em qualquer escola; \\
\hline 111 & talvez os alunos não teriam o mesmo nível de especificidade \\
\hline 112 & em seu conhecimento de mundo, mas a questão social do debate é algo \\
\hline 113 & que interessa à todos nós brasileiros. E, de forma geral, como cidadãos \\
\hline 114 & e alunos do ensino médio, é importante que eles saibam se posicionar \\
\hline 115 & em relação à temas delicados e a escola é um dos espaços \\
\hline 116 & em que eles podem exercitar isso. A verdade é que já o fazem \\
\hline 117 & nos intervalos, nos corredores...mas essa é uma discussão muito rica \\
\hline 118 & para ficar escondida nos bastidores e acho que a escola fazer uso disso \\
\hline 119 & seria de grande benefício pra formação dos alunos. \\
\hline
\end{tabular}

A discussão desenvolvida nesse excerto, somada às outras instâncias analisadas do excerto 4, mostra como a questão ética, inclusiva e reflexiva é significativa para Elis, construindo identidades-crenças-emoções de professora ética e preocupada em promover a reflexão crítica em suas aulas. No excerto 1 do segundo diário, elas emergem por avaliações de apreciação positiva com gradação muito elevada das linhas 107 a 119. Além disso, pelo uso de recursos de engajamento de contração dialógica (como em 'a questão social do debate é algo que interessa à todos nós brasileiros' 'é 
importante...' e 'a verdade é... .' nas linhas 112 a 114 e 116) ela parece se mostrar como conhecedora das necessidades dos alunos e nessas escolhas ela também pode estar se construindo como boa professora. Voltando ao memorial, percebemos como a experiência de preparação para a regência é retomada por Elis sob outras perspectivas, o que sugere que, ao lançar seu olhar sobre o que tinha acontecido, ela já está em outro momento de sua trajetória identitária.

\section{Memorial de estágio - Excerto 8}

\begin{tabular}{|l|l|}
\hline 81 & No começo, me senti um pouco insegura \\
\hline 82 & em relação ao tema da aula (medicina tradicional e alternativa) \\
\hline 83 & e cheguei a pensar em pedir pra trocá-lo. \\
\hline 84 & Mas achei que seria melhor para o meu desenvolvimento como professora \\
\hline 86 & encarar a situação como um desafio \\
\hline 87 & A regência em si me deixou muito contente. \\
\hline 88 & Foi a primeira vez que eu dei uma aula completa \\
\hline 89 & e, de forma geral, ela correu bem. \\
\hline 90 & Tenho certeza que ter uma boa experiência na minha primeira aula \\
\hline 91 & foi um fator decisivo na minha escolha de seguir na profissão e, por isso, \\
\hline 92 & sinto muita gratidão pelas professoras, pelos alunos e pela escola. \\
\hline
\end{tabular}

No Excerto 8 de seu memorial de estágio, Elis opta por recursos discursivos de afeto negativo (em me senti um pouco insegura em relação ao tema da aula (medicina tradicional e alternativa) e cheguei a pensar em pedir para trocá-lo, linhas 81 a 83) para se avaliar, mas diminui a intensidade da gradação (com o um pouco), de onde emerge a identidade de estagiária mais segura. Parece também haver uma mudança na forma como ela se refere a si mesma, assumindo-se como professora em desenvolvimento (cf. princípio de indexicalidade) na linha 84 , que se soma a uma postura de pessoa perseverante e capaz, construída por meio de avaliações de julgamento positivo: ela se posiciona como alguém que 'encara o que a aflige como desafio' (linha 85) e relata os frutos desse esforço novamente reiterando sua capacidade em assim consegui completar a preparação (linha 86).

Elis encerra a parte de seu memorial dedicada ao instituto externando felicidade com relação à regência, por gradação alta de afeto (em A regência em si me deixou muito contente, linha 87), mas, ao abordar a aula em si ela abranda a sua avaliação por apreciação positiva, modalizando-a (com de forma geral, ela correu bem, linha 89). Essa seleção pode estar ligada às relações de poder que existem entre ela e sua leitora (a professora de Prática de Ensino), 
que também foi sua avaliadora na regência. Sob essa interpretação, baseada no princípio de posicionalidade, é possível que Elis se mostre como aluna/avaliada, que compartilha com a sua interlocutora o conhecimento de que a regência apresentou alguns problemas. De qualquer forma, o aspecto emocional se sobressai (e parece ser considerado adequado dentro da relação entre escritora e leitora), mostrando-se essencial em suas (re)construções identitárias, como afirmado por Zembylas e Schutz (2009).

Cumpre ressaltar o uso das mesmas escolhas lexicogramaticais (uma boa experiência, na linha 35 do Diário 1 e nas linhas 11 e 90 do memorial) para descrever diferentes momentos em que Elis está decidindo sobre sua identidade como professora. No diário, ela se constrói como participante ativa do estágio na busca de torná-lo uma boa experiência, da qual se infere também que ela se via preocupada com isso. No início do memorial, ela revela o porquê dessa insegurança: não ter tido uma boa experiência na escola foi um dos motivos geradores de dúvidas quanto à docência e a sua construção como insegura quanto ao ambiente escolar. Já no Excerto 8, Elis retoma a mesma expressão para marcar sua reformulação como decidida pela carreira docente com grande assertividade, usando recursos de engajamento de contração dialógica: tenho certeza que ter uma boa experiência na minha primeira aula foi um fator decisivo na minha escolha de seguir na profissão e, por isso, sinto muita gratidão pelas professoras, pelos alunos e pela escola (linhas 90 a 92). No entanto, dessa vez, ela se reconstrói pela apreciação positiva da experiência, atrelando sua escolha pela docência à sua integração em nosso contexto com afeto inscrito com gradação alta, no campo da satisfação (em sinto muita gratidão), avaliações das quais também emerge a identidade-crença-emoção de estagiária acolhida em nossa comunidade de prática (pelas professoras, pelos alunos e pela escola). Assim, a licencianda finaliza seu texto da mesma forma que nos conduziu por toda essa jornada, destacando as relações interpessoais como essenciais em seu processo de tornar-se, tanto no nível profissional quanto no pessoal, ecoando o que fez na introdução ao seu memorial. A seguir, mais uma vez apresento alguns aspectos desenvolvidos nesta subseção de forma resumida no quadro 10. 
Quadro 10 - Resumo de algumas das (re)construções identitárias de Elis como membro da comunidade de prática de IFE

\begin{tabular}{|c|c|}
\hline DADOS & (RE)CONSTRUÇÕES IDENTITÁRIAS \\
\hline $\begin{array}{c}\text { Vídeo } \\
\text { Excerto } 1 \\
\text { "Agora eu quero } \\
\text { ser professora } \\
\text { de IFE" }\end{array}$ & $\begin{array}{l}\text { - Aluna de Letras e estagiária experiente } \\
\text { - Mudada, mostrando-se adaptada à nossa } \\
\text { comunidade, decidida a seguir a carreira } \\
\text { e aspirante a docente de IFE como } \\
\text { integrante do IFRJ (em "quero ser } \\
\text { professora de IFE, eu quero vir pra cá") } \\
\text { - Ainda não pronta para lecionar em uma } \\
\text { escola técnica } \\
\text { - Crenças de que a profissão docente exige a } \\
\text { atuação em diferentes instituições; de que } \\
\text { deve haver o acúmulo de outras } \\
\text { experiências escolares antes de ingressar } \\
\text { como docente em escolas como o instituto; } \\
\text { de que existe uma maior dificuldade para ser } \\
\text { admitido como professor em escolas } \\
\text { federais; de que o IFE não se restringe a } \\
\text { 'uma matéria escolar'; e de que a gramática } \\
\text { não deve ser a base do ensino de línguas. } \\
\text { - Praticante de IFE, membro da nossa } \\
\text { comunidade de prática }\end{array}$ \\
\hline
\end{tabular}

RECURSOS DISCURSIVOS

Princípios de emergência, de posicionalidade e indexicalidade

Apreciação positiva e engajamento de contraexpectativa ("engraçado")

Apreciação positiva com gradação muito alta do estágio

$$
\begin{gathered}
\text { Julgamento quanto à sua } \\
\text { capacidade }
\end{gathered}
$$

Afeto positivo para avaliar como se sente/entende quanto à docência naquele momento em contraste com a insegurança do passado

Afeto positivo evocado e gradação com polaridade alta, pela repetição (quando Elis declara, sobre o IFE, "quero que essa disciplina fique / permaneça em minha vida"

\section{Conversa 1 \\ Excerto 4}

"Fica uma coisa mais livre assim de se trabalhar"
- Colaboradora com perfil integrador

- Estagiária/ membro menos experiente
Princípio de relacionalidade (por adequação) e de posicionalidade Engajamento (expansão dialógica) para mostrar seu posicionamento com modalização de probabilidade baixa

\section{Conversa 3}

Excerto 1

"A gente faz
- Coconstrução de Elis, Enzo e eu como:

$\checkmark$ Membros da comunidade de prática de IFE e parceiros dos alunos

$\checkmark$ Pares mais competentes e grupo de apoio para os novos estagiários

$\checkmark$ Parte do 'grupo de humanas'

- Crenças-emoções-identidades sobre:

$\checkmark$ a relação entre professores, alunos e conhecimentos (de cooperação e parceria, de que todos ensinam e todos aprendem; e de que o fato de o professor não saber algumas coisas não é algo negativo)

$\checkmark$ a relação de colaboração entre professores

$\checkmark$ a cobrança do saber (representada pelo 'fazer prova' visto como gerador de insatisfação) em detrimento da curiosidade e entusiasmo que poderiam ser suscitadas.

- Construção de Elis como praticante de IFE e não-aluna
Princípio de relacionalidade (por autorização e por adequação), de indexicalidade (em 'nós', 'nossa' e 'a gente') e de posicionalidade

Julgamento positivo evocado quanto às ações dos membros da comunidade no apoio mútuo, com essa avaliação e as ideias de 'grupo'

e 'colaboração' reforçadas por gradação pela repetição

Afeto positivo inscrito com gradação muito alta para falar sobre suas afinidades com 0 instituto

Apreciação negativa do 'fazer prova' (como 'chato e pesado') e apreciação positiva evocada do trabalho como praticante de IFE 


\begin{tabular}{|c|c|c|}
\hline $\begin{array}{l}\text { Vídeo } \\
\text { Excerto } 2 \\
\text { "Está tudo muito } \\
\text { mais ligado do } \\
\text { que a gente } \\
\text { pensa" }\end{array}$ & $\begin{array}{l}\text { - Mais segura do que antes para voltar ao } \\
\text { ambiente escolar por reconhecer-se } \\
\text { acolhida pelos professores e alunos da } \\
\text { comunidade de prática de IFE. } \\
\text { - Colaboradora ativa em nossa } \\
\text { comunidade de prática } \\
\text { - Satisfeita e integrada ao contexto escolar } \\
\text { - Identidades-emoções de estagiária } \\
\text { experiente e satisfeita com o estágio e a } \\
\text { crença de que ele é um dos alicerces de sua } \\
\text { carreira docente }\end{array}$ & $\begin{array}{l}\text { Afeto (insegurança) quanto ao } \\
\text { ambiente escolar com gradação } \\
\text { baixa seguido de reformulação dessa } \\
\text { crença- emoção-identidade por meio } \\
\text { de apreciação positiva com } \\
\text { gradação cada vez mais alta } \\
\text { Julgamento positivo de si } \\
\text { (de capacidade) } \\
\text { Várias avaliações positivas ligadas } \\
\text { ao estágio por apreciação e por } \\
\text { afeto com gradação muito alta }\end{array}$ \\
\hline $\begin{array}{l}\text { Memorial de } \\
\text { estágio } \\
\text { Excerto } 1\end{array}$ & $\begin{array}{l}\text { - Pessoa/profissional em processo } \\
\text { - Pessoa que se transformou: não é mais } \\
\text { estagiária e adolescente. Agora é } \\
\text { professora e adulta } \\
\text { - Identidades-emoções de estagiária } \\
\text { experiente e satisfeita com o estágio }\end{array}$ & $\begin{array}{l}\text { Julgamento positivo de si mesma } \\
\text { O estágio é avaliado por apreciação } \\
\text { positiva (reação, composição e } \\
\text { valoração) com gradação alta }\end{array}$ \\
\hline $\begin{array}{l}\text { Memorial de } \\
\text { estágio } \\
\text { Excerto } 2\end{array}$ & $\begin{array}{l}\text { - Apavorada quanto à volta ao contexto } \\
\text { escolar por ter crenças/emoções muito } \\
\text { negativas sobre ele; } \\
\text { - Inexperiente na docência e preocupada } \\
\text { em ajudar os alunos e ser bem tratada por } \\
\text { eles; } \\
\text { - Crenças rememoradas do passado, que } \\
\text { parecem ter sido desconstruídas a partir das } \\
\text { interações no estágio: } \\
\checkmark \text { quanto ao preparo do professor de IFE e à } \\
\text { importância dada ao conhecimento das } \\
\text { disciplinas específicas e do vocabulário } \\
\text { técnico. } \\
\checkmark \text { quanto ao distanciamento das ciências para } \\
\text { o profissional de Letras; } \\
\checkmark \text { quanto ao possível isolamento e desamparo } \\
\text { no contexto de ensino de IFE. }\end{array}$ & $\begin{array}{c}\text { Afeto de insegurança inscrito e } \\
\text { evocado com gradação alta quanto } \\
\text { à docência e ao estágio antes de } \\
\text { iniciá-lo } \\
\text { Apreciação negativa dos primeiros } \\
\text { contatos com o IFE (como } \\
\text { "desconcertantes") } \\
\text { Julgamento negativo quanto à sua } \\
\text { capacidade em atuar em nossas } \\
\text { aulas }\end{array}$ \\
\hline $\begin{array}{c}\text { Memorial de } \\
\text { estágio } \\
\text { Excerto } 3\end{array}$ & $\begin{array}{l}\text { Em sua reformulação, Elis se constrói como } \\
\text { - Praticante de IFE, atenta e capaz } \\
\text { - Aprendiz autônoma e estagiária } \\
\text { proativa, mais confiante e assertiva } \\
\text { - Membro de nossa comunidade de } \\
\text { prática, compartilhando conosco alguns } \\
\text { sentimentos e crenças, como de que: } \\
\checkmark \text { O professor de inglês, deveria se envolver } \\
\text { na pesquisa dos temas que despertam o } \\
\text { interesse e incitem o pensamento crítico } \\
\checkmark \text { O foco não deve ser a gramática, } \\
\checkmark \text { A participação dos alunos deve ser } \\
\text { encorajada e seu conhecimento deve ser } \\
\text { valorizado para um ensino-aprendizagem } \\
\text { mais dinâmico e colaborativo }\end{array}$ & $\begin{array}{c}\text { Apreciação positiva e engajamento } \\
\text { de contraexpectativa (em Mas } \\
\text { rapidamente percebi que não seria } \\
\text { assim) } \\
\text { Muitas instâncias de julgamento } \\
\text { positivo de si mesma } \\
\text { Princípio de emergência e de } \\
\text { relacionalidade } \\
\text { (por adequação) }\end{array}$ \\
\hline
\end{tabular}




\begin{tabular}{|c|c|c|}
\hline $\begin{array}{l}\text { Memorial de } \\
\text { estágio } \\
\text { Excerto } 4\end{array}$ & $\begin{array}{l}\text { - Estagiária e membro experiente de } \\
\text { nossa comunidade, conhecedora de } \\
\text { nossas práticas e não mais cheia de } \\
\text { dúvidas quanto à escolha pela docência } \\
\text { - Participante ativa } \\
\text { - Das várias menções à sua prática na } \\
\text { elaboração dos materiais no estágio também } \\
\text { emergem identidades de praticante de IFE, } \\
\text { capaz, criativa e útil. } \\
\text { - Alguém mais confiante e assertiva }\end{array}$ & $\begin{array}{c}\text { Princípios de emergência, de } \\
\text { relacionalidade (por adequação e } \\
\text { por autorização) e de } \\
\text { posicionalidade } \\
\text { Apreciação positiva com gradação } \\
\text { muito alta } \\
\text { Julgamento positivo de si } \\
\text { Afeto explícito de felicidade e } \\
\text { satisfação }\end{array}$ \\
\hline $\begin{array}{l}\text { Memorial de } \\
\text { estágio } \\
\text { Excerto } 5\end{array}$ & $\begin{array}{l}\text { - Estagiária e aprendiz acolhida na } \\
\text { comunidade de prática } \\
\text { - Elaboradora de materiais didáticos e } \\
\text { parte do grupo de estágio } \\
\text { - Colaboradora ativa da comunidade, mas } \\
\text { também como estagiária, que precisa da } \\
\text { permissão de sua professora regente para } \\
\text { intervir. } \\
\text { - Mais segura e integrada, identidade- } \\
\text { crença-emoção que emerge de todas as } \\
\text { avaliações positivas de si (sozinha ou como } \\
\text { parte do grupo) }\end{array}$ & $\begin{array}{l}\text { Princípios de emergência, } \\
\text { relacionalidade (adequação) } \\
\text { posicionalidade e indexicalidade } \\
\text { Julgamento positivo com } \\
\text { graduação alta } \\
\text { Afeto, por vezes evocado, de } \\
\text { satisfação e segurança. } \\
\text { Julgamento positivo quanto à sua } \\
\text { capacidade } \\
\text { Julgamento positivo do } \\
\text { comportamento da regente } \\
\text { Apreciação positiva com gradação } \\
\text { muito alta sobre a aula }\end{array}$ \\
\hline $\begin{array}{c}\text { Memorial de } \\
\text { estágio } \\
\text { Excerto } 6\end{array}$ & $\begin{array}{l}\text { - Preocupada quanto à sua conexão com } \\
\text { os alunos (identidade imbricada em } \\
\text { crenças/emoções de que é parte essencial } \\
\text { da profissão docente e do estágio a relação } \\
\text { de proximidade e confiança com alunos) } \\
\text { - Estagiária como posição que implica em } \\
\text { ser uma pessoa 'de fora' em busca de } \\
\text { integração e acolhimento } \\
\text { - Professora iniciante e em processo, certa } \\
\text { de seguir a carreira docente }\end{array}$ & $\begin{array}{l}\text { Afeto (insatisfação - por não ter a } \\
\text { proximidade com os alunos que } \\
\text { gostaria), o que é abrandado por } \\
\text { ponderação (como um recurso de } \\
\text { engajamento) e modalização para } \\
\text { diminuir a intensidade dessa } \\
\text { avaliação (gradação) } \\
\text { Julgamento e afeto positivos para } \\
\text { avaliar os alunos e como se sentiu } \\
\text { com o apoio deles }\end{array}$ \\
\hline $\begin{array}{c}\text { Memorial de } \\
\text { estágio } \\
\text { Excerto } 7\end{array}$ & $\begin{array}{l}\text { - Estagiária praticante de IFE. } \\
\text { - Elis dá destaque à sua dedicação apesar da } \\
\text { dificuldade e se constrói como esforçada, } \\
\text { comprometida e resiliente } \\
\text { - Identidades-crenças-emoções (de } \\
\text { estagiária capaz e mais segura) são } \\
\text { desenvolvidas em seu texto como } \\
\text { consequência de ter se identificado com a } \\
\text { abordagem e as professoras, ou seja, } \\
\text { emerge da sua construção como membro } \\
\text { da nossa comunidade de prática }\end{array}$ & $\begin{array}{l}\text { Princípios de emergência, de } \\
\text { indexicalidade e de parcialidade } \\
\text { Várias instâncias de julgamento } \\
\text { positivo de si com gradação muito } \\
\text { alta } \\
\text { Afeto positivo }\end{array}$ \\
\hline $\begin{array}{l}\text { Conversa } 3 \\
\text { Excerto } 2 \\
\text { "a gente faz um } \\
\text { pouquinho de } \\
\text { tudo" }\end{array}$ & $\begin{array}{l}\text { - Elaboradora de materiais didáticos parte } \\
\text { do grupo de estágio. } \\
\text { - Membro da comunidade de prática de } \\
\text { IFE, muito mais segura e integrada } \\
\text { - Identidade-crença-emoção de acolhida } \\
\text { nessa comunidade } \\
\text { - Colaboradora ativa da comunidade, mas } \\
\text { também como estagiária, que precisa da } \\
\text { permissão de sua professora regente } \\
\text { para intervir. }\end{array}$ & $\begin{array}{l}\text { Princípios de emergência, de } \\
\text { indexicalidade e de relacionalidade } \\
\text { (adequação) } \\
\text { Julgamento positivo quanto à sua } \\
\text { capacidade de preparar as aulas } \\
\text { seguindo as premissas da nossa } \\
\text { abordagem. Recursos de } \\
\text { julgamento positivo do } \\
\text { comportamento da regente e de } \\
\text { apreciação positiva com gradação } \\
\text { muito alta da aula, que foi fruto da } \\
\text { ideia dada por Elis }\end{array}$ \\
\hline
\end{tabular}




\begin{tabular}{|c|c|c|}
\hline $\begin{array}{l}\text { Diário sobre a } \\
\text { Regência } \\
\text { Excerto } 3\end{array}$ & $\begin{array}{l}\text { - Pesquisadora, ética, elaboradora de } \\
\text { materiais, colaboradora, dinâmica, } \\
\text { atenta aos alunos e preocupada em } \\
\text { promover o pensamento crítico, dentre } \\
\text { outras identidades-crenças-emoções } \\
\text { compartilhadas pela comunidade de prática } \\
\text { - Estagiária/professora autocrítica, em } \\
\text { processo, buscando melhorar }\end{array}$ & $\begin{array}{l}\text { Grande recorrência de escolhas } \\
\text { avaliativas de julgamento, em sua } \\
\text { maioria positivo de si mesma }\end{array}$ \\
\hline $\begin{array}{l}\text { Diário sobre a } \\
\text { Regência } \\
\text { Excerto } 1\end{array}$ & $\begin{array}{l}\text { - Professora ética e preocupada em } \\
\text { promover a reflexão crítica em suas } \\
\text { aulas } \\
\text { - Conhecedora das necessidades dos } \\
\text { alunos } \\
\text { - Boa professora }\end{array}$ & $\begin{array}{c}\text { Apreciação positiva com gradação } \\
\text { muito elevada e engajamento de } \\
\text { contração dialógica }\end{array}$ \\
\hline $\begin{array}{l}\text { Memorial de } \\
\text { estágio } \\
\text { Excerto } 8\end{array}$ & $\begin{array}{l}\text { - Professora em desenvolvimento } \\
\text { - Alguém que 'encara o que a aflige como } \\
\text { desafio' } \\
\text { - Aluna avaliada } \\
\text { - Decidida pela carreira docente } \\
\text { - Identidade-crença-emoção de estagiária } \\
\text { acolhida em nossa comunidade de } \\
\text { prática }\end{array}$ & $\begin{array}{l}\text { Princípios de emergência, } \\
\text { indexicalidade e posicionalidade } \\
\text { Julgamento positivo de si pelo seu } \\
\text { esforço, reiterando sua capacidade. } \\
\text { Apreciação positiva da experiência, } \\
\text { atrelando sua escolha pela docência } \\
\text { à sua integração em nosso contexto } \\
\text { Várias instâncias de afeto inscrito } \\
\text { com gradação alta, no campo da } \\
\text { satisfação quanto às professoras, } \\
\text { aos alunos e à escola }\end{array}$ \\
\hline
\end{tabular}

Fonte: Análise dos dados da pesquisa

No quadro 10, vemos como Elis se reconstrói em sua caminhada por meio da ressignificação de suas identidades, crenças e emoções, promovida pelas novas experiências no período de pré-serviço. Novamente, as setas destacam alguns momentos em que as reformulações identitárias da licencianda ficam muito patentes. Nos dados, ela descreve muitas afinidades com nosso contexto (seguindo o princípio de relacionalidade - adequação) e como ela foi se integrando cada vez mais em nossa comunidade de prática de IFE à medida que se constituía como docente. Dentro de sua reformulação 'de estagiária e adolescente para professora e adulta', emergem outras identidades, principalmente por recursos avaliativos muito positivos de afeto e julgamento de si (o que contrasta sobremaneira com suas avaliações de como se entendia, sentia, acreditava em relação à docência e ao contexto escolar no passado). Assim, das instanciações quanto às vivências de Elis no estágio, emergem suas identidades-crenças-emoções de decidida a seguir a profissão; estagiária e professora mais experiente, mas ciente de que está sempre em processo de aprendizagem e crescimento pessoal e profissional; conhecedora das práticas de IFE; pesquisadora; professora ética e preocupada em promover a reflexão crítica; elaboradora de materiais; colaboradora e atenta às necessidades dos alunos; 
além de outras nuances (cf. princípio de parcialidade) como membro de nossa comunidade de prática, se aproximando cada vez do centro da mesma.

\section{2 \\ Retomando alguns dos entendimentos possíveis a partir das análises dos dados}

Nesta seção, busco recorrer a algumas das interpretações e fazer conexões entre diferentes pontos discutidos na análise que podem ajudar nos entendimentos das questões propostas para esta pesquisa. Entretanto, não escrevo sobre essas questões separadamente, mas trago minhas reflexões entretecidas ao longo do texto. Antes de prosseguir, relembro essas questões, que foram apresentadas na introdução desta tese:

(1) Que identidades emergem nas escolhas lexicogramaticais e semânticas de Elis sobre o estágio em si, o nosso contexto específico (especialmente a abordagem de IFE e a participação em nossa comunidade de prática) e a docência? Como as interpretações de Elis se relacionam às suas (re)construções identitárias, principalmente quanto a tornar-se professora?

(2) Como as crenças e emoções de Elis se relacionam às suas identidades nesse processo? É possível observar reconstruções ao longo de sua caminhada no estágio?

(3) Que entendimentos podem ser gerados a partir das reflexões sobre as discussões desenvolvidas e debatidas nesta pesquisa para nossa comunidade de prática?

Como explicado no capítulo 5, as identidades são o foco deste estudo, mas elas se mostram imbricadas em crenças e emoções, o que também foi possível observar ao longo de toda a discussão na análise dos dados. Nela, percebemos como as identidades de Elis são dinâmicas, fluidas e estão sempre em movimento, e isso também acontece em sua relação com os outros construtos, formando um complexo intricado e movediço de identidades-crenças-emoções, representado na figura 12 . 


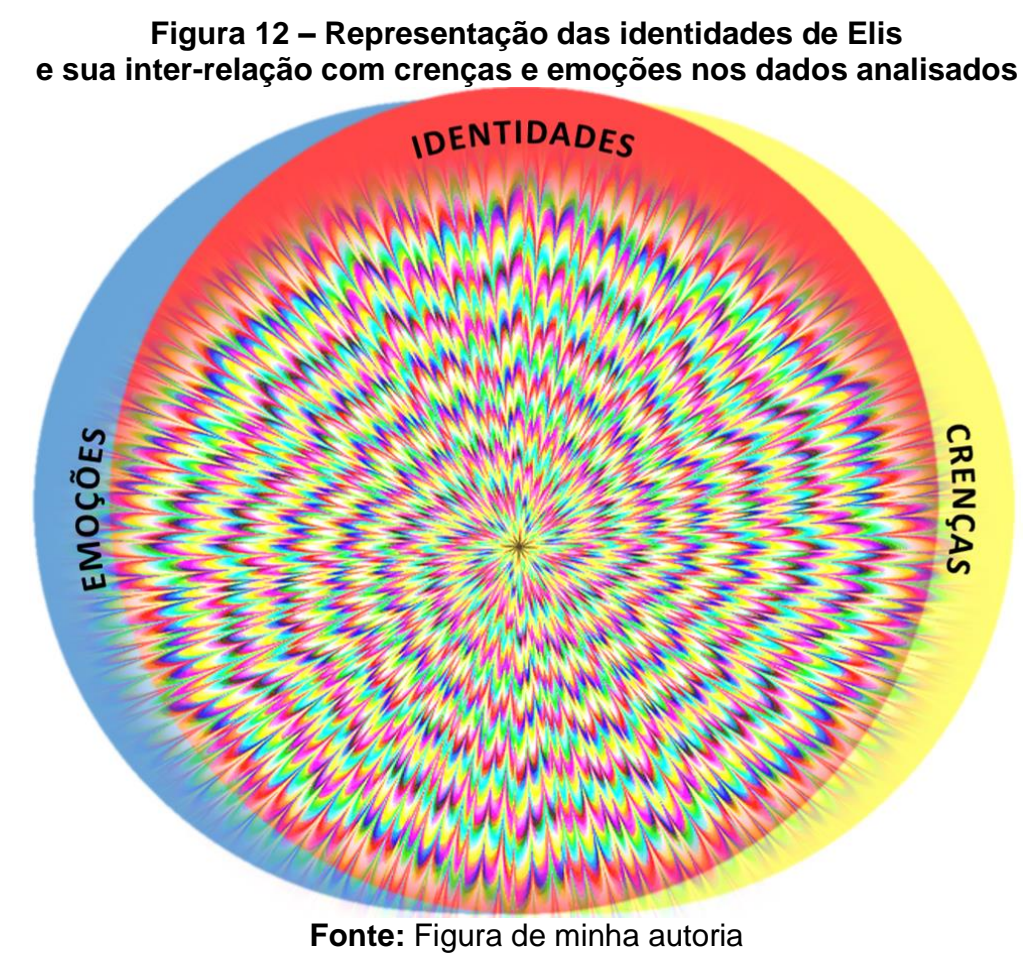

Com o objetivo de refletir sobre as questões de pesquisa, propus a organização da análise dos dados em três blocos temáticos (cada um em uma subseção), de forma que um reunisse algumas (re)construções de Elis como estagiária; outro como futura professora e não futura professora; e, um terceiro, como membro da comunidade de prática de IFE. As análises foram feitas à luz da Linguística Sistêmico-Funcional (especialmente do Sistema de Avaliatividade), como também de estudos socioconstrucionistas de identidades, dos quais destaquei a proposta de Bucholtz e Hall de 2005 para a abordagem desse construto. A partir das discussões na seção 6.1, depreende-se que existem vários entrelaçamentos entre os blocos sugeridos, sendo possível observar a emergência de algumas das múltiplas identidades de Elis durante o estágio, que são construídas na linguagem por recursos avaliativos de Atitude, dentro das categorias de afeto, julgamento e apreciação.

Na figura 13, agrupo as identidades que emergem dos dados selecionados de forma imagética, mostrando algumas das interconexões feitas por Elis e representando-as por meio de linhas tracejadas na cor laranja. Essas ligações são bilaterais, movediças e não rígidas, por isso a preferência por retratá-las como linhas não contínuas e a exclusão de setas. Lembro que as identidades estão em constante oscilação e, ao mesmo tempo, constituem e são constituídas por crenças e emoções, o que é representado pelo fundo que remete à ideia de movimento e difusão (como proposto na figura 12, que foi clareada aqui para 
melhor visualização da parte escrita). Além disso, as identidades escolhidas como pontos de partida para desenvolver e organizar a análise foram destacadas na imagem pelo uso das letras em caixa alta. Por fim, observa-se uma seta em cinza da esquerda para a direita, que busca simbolizar algumas das reconstruções identitárias observadas nos dados: na parte mais escura (à esquerda) estão aquelas que Elis relega ao passado ou que foram modificadas ao longo do estágio e a parte clara da seta inclui a sua reelaboração durante a caminhada identitária da licencianda.

Figura 13 - Algumas identidades de Elis que emergem dos dados

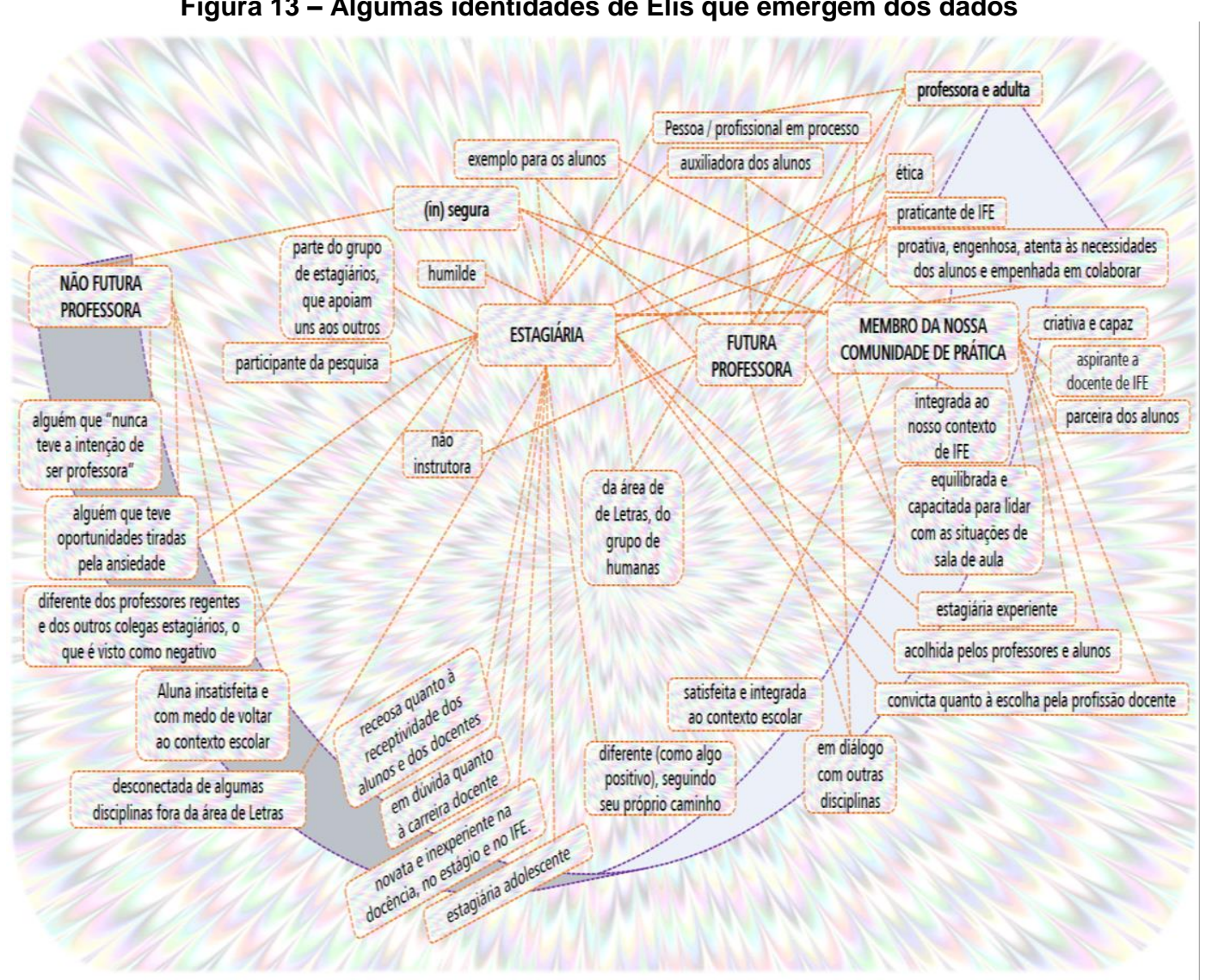

Fonte: Figura de minha autoria elaborada a partir da análise dos dados

A análise das identidades representadas na figura 13, que emergem das escolhas de Elis na linguagem (cf. LSF, principalmente o Sistema de Avaliatividade), sugere que há uma relação recíproca entre as mudanças em suas interpretações e as suas (re)construções ao longo do processo de tornar-se professora. Percebemos, por exemplo, que ao refletir sobre sua visão quanto à escola, à profissão docente e ao estágio antes de iniciá-lo, Elis avalia esses aspectos e, ao mesmo tempo, se constrói a partir de escolhas negativas, especialmente por afeto. De forma similar, ela se refere à sua inexperiência na docência, no estágio e no IFE nos seus primeiros momentos no instituto por 
recursos avaliativos negativos, mas suas interpretações vão se transformando à medida que sua relação com o contexto escolar por intermédio do estágio também se modificava. A seguir, no quadro 11, destaco alguns momentos da caminhada de Elis e suas perspectivas sobre a docência, o estágio e o IFE nos dados gerados para esta pesquisa.

Quadro 11 - Perspectivas sobre o estágio, o contexto de IFE e a escolha pela docência nos dados

\begin{tabular}{|c|c|c|c|}
\hline \multirow{2}{*}{$\begin{array}{c}\text { MOMENTOS } \\
\text { DA } \\
\text { CAMINHADA } \\
\text { DE ELIS }\end{array}$} & \multicolumn{3}{|c|}{ ALGUMAS INTERPRETAÇÕES SOBRE } \\
\hline & ESTÁGIO & IFE & DOCÊNCIA \\
\hline $\begin{array}{l}\text { Expectativas antes } \\
\text { do estágio }\end{array}$ & $\begin{array}{l}\text { 'Teste' para saber como é ser } \\
\text { professora e decidir se } \\
\text { seguiria a profissão. Medo de } \\
\text { voltar ao contexto escolar e de } \\
\text { como seria recebida. }\end{array}$ & $\begin{array}{l}\text { Falta de estudo sobre a área, } \\
\text { mas traz crenças/mitos como, } \\
\text { por exemplo, de que apenas } \\
\text { "envolve vocabulário e termos } \\
\text { técnicos" }\end{array}$ & $\begin{array}{c}\text { Alguém que "nunca teve a } \\
\text { intenção de ser } \\
\text { professora" e se avalia } \\
\text { como diferente como algo } \\
\text { negativo. }\end{array}$ \\
\hline $\begin{array}{l}\text { Reflexões após } \\
\text { algumas semanas } \\
\text { conosco }\end{array}$ & $\begin{array}{l}\text { Processo que a fez 'se sentir } \\
\text { melhor', experiência muito } \\
\text { produtiva e "melhor do que o } \\
\text { esperado". Momento do } \\
\text { processo de formaçã̃o docente } \\
\text { onde o licenciando } \\
\text { gradualmente se acostuma } \\
\text { com suas futuras funções com } \\
\text { o apoio de seus pares }\end{array}$ & $\begin{array}{l}\text { Considera IFE como ensino não } \\
\text { tradicional, que a faz sair do } \\
\text { lugar comum e "aprender coisas } \\
\text { interessantes", mas entende-se } \\
\text { como novata e inexperiente. }\end{array}$ & $\begin{array}{l}\text { Diferente dos outros } \\
\text { professores e colegas } \\
\text { como algo positivo. } \\
\text { Exemplo para os alunos, } \\
\text { pessoa e profissional em } \\
\text { processo. Decidida a } \\
\text { seguir a carreira docente. }\end{array}$ \\
\hline $\begin{array}{l}\text { Avaliações após o } \\
\text { término do estágio }\end{array}$ & $\begin{array}{l}\text { "Parte mais significativa da } \\
\text { reta final da graduação", } \\
\text { "extremamente positivo, útil e } \\
\text { recompensador" e "essencial" } \\
\text { em seu processo de } \\
\text { amadurecimento. Agradecida } \\
\text { pelo acolhimento recebido. }\end{array}$ & $\begin{array}{c}\text { Elis se descreve como praticante } \\
\text { de IFE, participando ativamente } \\
\text { e compartilhando dos preceitos } \\
\text { de nossa comunidade, } \\
\text { mostrando-se agora membro da } \\
\text { mesma. }\end{array}$ & $\begin{array}{l}\text { Pessoa integrada ao } \\
\text { contexto escolar e } \\
\text { capacitada para lidar com } \\
\text { as situações de sala de } \\
\text { aula. Parece muito mais } \\
\text { segura quanto à docência } \\
\text { e declara-se professora. }\end{array}$ \\
\hline
\end{tabular}

Fonte: Elaborado a partir da análise dos dados

Pelo quadro 11, notamos que as visões de Elis sobre o estágio, o ensino de IFE e a docência vão se transformando à medida que ela conhece cada vez mais o ambiente, interage com os professores e alunos do instituto e se insere em nossa comunidade de prática. Esse processo foi gradual e está diretamente ligado às (re)construções de suas identidades, principalmente no processo de tornar-se docente. Acredito que as novas experiências no estágio e o acolhimento pelos professores e alunos criaram um ambiente propício para o questionamento e reformulação de suas identidades-crenças-emoções. No entanto, entendo que aquelas que são deixadas pelo caminho (ilustradas na parte cinza escuro da seta da figura 13) não são substituídas, mas ressignificadas ao longo de processo pessoal e profissional de Elis de tornar-se.

Um aspecto que se mostra muito presente nesse processo é a oscilação nas construções da licencianda por diversos graus intermediários entre mais insegura e mais segura. Essas nuances de (in) segurança permeiam todos os dados, tendo 
sido discutidas, por exemplo, na análise da Conversa 2 (ver seção 6.1.2). A conclusão da licencianda nessa conversa (em Eles que dão segurança...você fica nervoso... ao mesmo tempo você se sente FELIZ né ... de você ter conseguido fazer) tenta traduzir como Elis se entendia, sentia, acreditava naquele momento - como feliz, capaz, dependente, segura e insegura ao mesmo tempo - em uma difusão de identidades-crençasemoções (considerando também os princípios de posicionalidade e parcialidade sugeridos por BUCHOLTZ e HALL, 2005), o que emerge por meio de afeto. Considero esse excerto muito representativo de como identidades, crenças e emoções se entrelaçam e emergem nos textos por recursos avaliativos, bem como da complexidade das nossas construções, mesclando aspectos que, à primeira vista, podem parecer opostos (como segurança e insegurança).

Chamo a atenção para a seleção do processo 'sentir', que não aparece apenas na Conversa 2, mas que é recorrente nos dados gerados, salientando como o afeto é manifesto e parece essencial nas construções identitárias de Elis. Em muitas ocorrências, grande parte desse 'sentir' parece vir de fora, ou seja, ele é continuamente atrelado às relações da licencianda com o contexto. No memorial, por exemplo, Elis diz que se sente melhor por estar em uma escola técnica, que sentia muita pressão porque os colegas tinham alguma experiência e ela não e que sentia que algumas turmas eram mais receptivas com ela. Nesses exemplos, vemos como a influência da criação ou não de vínculos com os outros e de seu desejo de inserção são muito proeminentes e relevantes nas avalições de Elis em seu processo identitário.

Parece haver uma dependência do suporte nas relações interpessoais e uma busca pela sensação de pertencimento, o que pode ser percebido em vários momentos. Observamos nos dados, por exemplo, como a relação com os alunos e professores é central nas (re)construções de Elis como estagiária, futura professora e membro da comunidade de prática (por vezes por adequação e outras por distinção, seguindo o princípio de relacionalidade proposto por BUCHOLTZ e HALL, 2005): ela cita repetidamente sua preocupação em ajudá-los e a necessidade de ser percebida como alguém que poderia fazer isso. Destaco, aqui, quatro desses momentos: quando menciona, 1. antes de começar o estágio, que esperava auxiliar; 2 . após seu término, que sua prioridade em sala de aula é conseguir ajudar os alunos; 3. que ficou feliz quando fizeram perguntas; e 4. quando fala da regência e descreve sua reformulação como uma pessoa que pensava que ficaria perdida, mas se percebeu preparada pois 'conseguia entender 
e pôde ajudar'. Concomitantemente, ela se constitui em sua caminhada na criação de laços de parceria, principalmente com os professores, o que parece ter amparado essa sua reformulação como estagiária e professora que se entende, sente e está cada vez menos insegura, chegando a um momento de sua jornada em que ela se declara "professora e adulta" (reconstrução ilustrada no final da seta na figura 13).

De tudo o que foi dito, depreende-se que a (in) segurança entretecida nos discursos aqui analisados parece ser desenvolvida e retroalimentada por identidades, crenças e emoções coconstruídas nas relações interpessoais. Concordo com Mahn e John-Steiner (2002) quando falam da importância de se promover o a confiança por meio do apoio emocional recíproco nas interações dos participantes da aprendizagem. Por isso, acredito que não basta lançar os estagiários nas salas e pedir que somente observem e/ou cumpram tarefas mecânicas, pois é imprescindível que haja envolvimento humano, o compartilhamento de experiências e o amparo mútuo. Enfatizo aqui a ideia de reciprocidade nas tentativas de entender nossas identidades, crenças e emoções pois creio que todos estamos em processo e que o estágio (que, a meu ver, é um momento muito profícuo para o crescimento de todos) precisa ser uma construção conjunta.

No próximo capítulo, trago algumas reflexões sobre o processo de pesquisa aqui desenvolvido, bem como sugiro possíveis encaminhamentos futuros deste estudo. Prossigamos, então, para as considerações, que não vejo como finais, mas como alguns passos que podem ser os primeiros para instigar novas pesquisas no contexto de estágio. 


\section{Algumas considerações e possíveis encaminhamentos}

[...] da discussão e da interação desponta a compreensão e desta a vontade de experimentar, para continuar a discutir e entender mais. E assim prosseguir em um processo sem fim.

(CELANI, 2010, p. 62)

A presente tese propôs-se a apresentar uma pesquisa que faz parte da busca de entendimentos sobre o estágio na comunidade de prática de IFE a qual pertenço e teve como objetivo a investigação das (re)construções das identidades de uma das participantes desse contexto, a licencianda Elis, em seu processo de tornar-se professora. Para tanto, o arcabouço teórico fundamenta-se em perspectivas socioconstrucionistas de identidades (MOITA LOPES, 2003; BUCHOLTZ; HALL, 2005; FABRÍCIO, 2011), bem como estudos sobre crenças (KUDIESS, 2005; BARCELOS; VIEIRA-ABRAHÃO, 2006), emoções (ZEMBYLAS, 2004; REZENDE; COELHO, 2010) e a relação entre esses três construtos (BARCELOS, 2013 e 2017). Além disso, a base teórico-metodológica da Linguística Sistêmico-Funcional (HALLIDAY; MATTHIESSEN, 2014) e, como parte desta, do Sistema de Avaliatividade (MARTIN; WHITE, 2005; VIAN JR.; SOUZA; ALMEIDA, 2011) ofereceu subsídios para investigar as identidades e outros significados construídos na linguagem, considerando a relação recíproca desta com o contexto.

Para esta pesquisa, que segue o paradigma qualitativo-interpretativista (ERICKSON, 1986; DENZIN; LINCOLN, 2006), foram analisados excertos transcritos de cinco conversas das quais Elis participou, quatro de suas produções escritas e um vídeo onde ela fala sobre o período de pré-serviço. Reafirmo que estou ciente de que outros excertos poderiam ter sido contemplados e que os dados poderiam ter sido interpretados à luz de outras escolhas teóricometodológicas, bem como a partir de perspectivas distintas. Uma possibilidade seria, por exemplo, propor a análise das narrativas (ABREU, 2018; BASTOS; BIAR, 2015) dos participantes, que é um dos encaminhamentos futuros que considero seguir.

Nos dados analisados, Elis mostra suas visões sobre diversos aspectos (dentre os quais estão seu comportamento no estágio, suas experiências escolares, a docência, o ato de avaliar, o IFE, a escola, os alunos, os professores, como ela foi recebida pelas pessoas, a regência, o papel do estágio e os espaços que cabiam a cada um naquele contexto) e ela os avalia por meio de diferentes recursos, construindo-se em seus textos orais e escritos principalmente por 
escolhas atitudinais de afeto, dentro do domínio semântico do Sistema de Avaliatividade. Por suas escolhas lexicogramaticais, foi possível observar, por exemplo, como são recorrentes as construções da licencianda como (in)segura, oscilando entre as diferentes nuances de polaridade de afeto positivo e negativo, o que faz parte do complexo intricado de suas identidades-crenças-emoções.

Ao analisar os dados em conjunto, pode-se interpretar também que Elis passa a se diferenciar (cf. princípio de relacionalidade) menos de seus colegas estagiários e professores, e a se posicionar de forma mais assertiva nas interações com o decorrer do período de pré-serviço, parecendo se identificar cada vez mais com o ambiente escolar e com a docência. Sua relação com o estágio em si também é modificada, posto que inicialmente ele era encarado como um elemento estanque do resto da licenciatura, que serviria como 'teste' sobre a carreira docente, mas, no decorrer do caminho, ele passa a ser visto como parte essencial de sua formação e integrado à graduação como um todo. Além disso, notamos que muitas das avaliações das experiências nesse contexto e sua relação com a profissão eram negativas quando se referiam ao passado ou a ela mesma no início do estágio. No entanto, parte dessa negatividade parece ter sido transformada por meio das oportunidades de reflexão e ressignificação de identidades, crenças e emoções em nossas interações na comunidade de prática. Esses são apenas alguns dos exemplos de (re)construções de identidades (imbricadas em crenças e emoções) da estagiária, que parecem ter sido muito significativas durante o período de pré-serviço.

Assim, somos levados a compartilhar a trajetória identitária de Elis, da qual destaco a sua relação com a docência: ela começa o estágio como alguém que diz que nunca quis ser docente; mas que, com as interações lá vividas, começou a considerar essa possibilidade e podia se ver como futura educadora; até ela chegar ao momento após o estágio, quando se define como professora. No entanto, é importante mencionar que esse processo não é linear e simples e que a licencianda encontrou muitos obstáculos (como, por exemplo, o medo quanto à sua inexperiência, a como seria tratada e ao desconhecimento sobre o IFE), que foram sendo superados aos poucos, tendo as interações em nossa comunidade de prática se mostrado como um dos fatores essenciais em seu desenvolvimento. Quanto a isso, as discussões sobre os dados também sugerem que a sensação de pertencimento dos licenciandos, o desenvolvimento da confiança e a real integração deles ao contexto do estágio precisam do empenho e dedicação de todos nós professores em formação, não só no compartilhamento de experiências, mas também com o apoio emocional recíproco e no envolvimento na busca de 
entendimentos sobre nossas práticas, bem como nossas (re)construções de identidades, crenças e emoções.

$\mathrm{Na}$ verdade, acredito que todo o nosso tempo juntos pode ser fonte de enriquecimento pessoal e profissional mútuos e esta tese também se mostra como um exemplo das tentativas de um grupo de pessoas buscando aproveitar esses momentos de ensino-aprendizagem conjuntos, trabalhando em parceria no estágio. Entretanto, é importante salientar que essa possível contribuição não se traduz em um caminho a seguir, apenas representam algumas de nossas experiências que podem suscitar reflexões, inquietações e novas pesquisas sobre o estágio docente, não somente para nós em nossa comunidade de prática. Assim, entendo que a pesquisa pode extrapolar os muros de nossa comunidade de prática, ser retomada a partir de outras perspectivas e seguir novos caminhos para a exploração do contexto amplo de formação de professores. Dessa maneira, espero que este trabalho seja uma colaboração para a área de Linguística Aplicada, especialmente no que concerne aos estudos sobre o estágio supervisionado na formação docente.

Além disso, acredito que o processo de questionamento, análise e reflexão das identidades de Elis e sua relação complexa com crenças e emoções não só trouxe contribuições para o desenvolvimento de entendimentos situados e locais para mim e para a licencianda, mas também promoveu oportunidades de aprendizagem para a formação de todos os professores envolvidos, serviu como motivação para nossa comunidade de prática continuar a pesquisa sobre o estágio no contexto de IFE de forma mais dinâmica e inclusiva, como também pode ser visto como um exemplo representativo de como o estágio pode ser um momento de formação para todos os docentes. Ou seja, na caminhada de construção e investigação sobre o estágio aqui abordada, percebemos como é necessário o engajamento de todos os participantes (alunos, professores da escola, estagiários e professores da universidade) nesse período de formação docente, que eu não chamaria de apenas 'inicial', mas 'inicial e continuada' por considerar que há o compartilhamento de conhecimentos conjunta e que a aprendizagem não é só dos estagiários.

É importante mencionar também que, como Jordão e Bührer (2013, p. 679), entendo que o estágio pode se apresentar como uma "arena de conflitos" e, como as autoras, considero que conflitos podem ser muito positivos se vistos como uma chamada para reflexão e como "espaços de crescimento pessoal e de construção profissional". Nesse sentido, esta pesquisa se mostrou muito relevante por gerar ainda mais questionamentos sobre o que nós (professores e estagiários) estamos 
fazendo e nossas (re)construções. Algumas das questões que foram mencionadas no decorrer das análises e que têm sido usadas como base para novas discussões são: a) Que visões nós (estagiários e professores) temos sobre 'experiências' e sua relação com a formação docente?; b) Que crenças, identidades e emoções emergem em nossos discursos quanto aos espaços (não só físicos) que os diferentes participantes ocupam no estágio?; c) Por que os estagiários custam a se perceber como acolhidos em nossa comunidade de prática?; d) Como podemos trabalhar juntos para melhor integração de todos?; e) Outros estagiários (e professores) tiveram experiências que os fazem questionar a opção pela docência?; f) Como podemos abordar essas identidades-crençasemoções de insegurança quanto à carreira no estágio?; g) Quais são as nossas concepções sobre o preparo para ser professor de IFE e da trajetória seguida para conseguir trabalhar em uma escola como o IFRJ?; h) Como nos sentimos e o que pensamos sobre a elaboração, adaptação e uso de materiais didáticos, levando em conta o uso de tecnologias e inovações pedagógicas?; i) Por que a preparação para a regência é comumente vista como uma tarefa solitária?; e j) Como isso se relaciona às nossas interpretações quanto às nossas identidades no contexto de estágio? Questionamentos como esses também podem ser geradores de reflexões para os leitores deste trabalho que estejam interessados em investigar a construção do estágio supervisionado docente de professores de línguas em outros contextos.

Além dessas perguntas aqui retomadas, ainda surgiram outras em meu processo de escrita, que considero poder se tornar base para encaminhamentos futuros. Dentre elas estão a minha preocupação em como engajar os diferentes participantes do estágio na pesquisa conjunta sobre nosso contexto; e, ainda considerando os dados gerados até o presente momento (não só os que foram aqui analisados, mas também os outros listados na p. 96 desta tese), a reflexão e discussão sobre os pontos de encontro entre as nossas (re)construções nos discursos dos professores em formação (professores de IFE, de Prática de Ensino e os estagiários, que são alunos-professores) no estágio em nossa comunidade de prática, bem como sobre as inquietações que surgiram (e outras que ainda vão ser construídas nesse processo).

Portanto, para prosseguir na investigação, um possível encaminhamento seria ampliar este estudo e investir no trabalho conjunto para pensar e discutir sobre nossas interações no contexto de estágio de forma a integrar outros participantes, nos coconstruindo tanto nos momentos de concordância como nos de divergência "de forma crítica e respeitosa", como afirma Elis em seu diário (ver 
Anexos, p. 205). Acredito que esse movimento de escuta, reflexão conjunta e das diferentes interpretações, pode proporcionar experiências que podem se tornar fontes de aprendizado para todos nós (estagiários, professores regentes e de Prática de Ensino), contribuindo para nossa formação crítica, ética e reflexiva.

Concordo com Celani (2009a, p. 21) quando diz que podemos fazer uso da incerteza, transformando-a em incentivo para o nosso desenvolvimento, "em uma junção de participação e antecipação" e que devemos valorizar o processo de investigação até mais do que as próprias respostas. Logo, acredito que, no processo de pesquisa, é muito produtivo o fato de muitas vezes surgirem mais perguntas e parece que isso foi exatamente o que aconteceu após a minha própria caminhada: propus algumas questões para analisar os dados e me deparei com muitas outras que surgiram ao longo do caminho. Assim, com esta tese, dou alguns passos na busca de entendimentos sobre o contexto em que atuo, não com o objetivo de achar respostas, mas de fomentar questionamentos, cujas discussões podem suscitar novos significados sobre o estágio não só para nós, participantes da pesquisa e da comunidade de prática de IFE, mas também para os leitores interessados. 


\section{8 \\ Referências bibliográficas}

ABREU, A. Desafios do magistério: a coconstrução de identidades em microcenas narrativas de professores da Educação Básica. 191p. Tese (Doutorado em Estudos da Linguagem) - Departamento de Letras, Pontifícia Universidade Católica do Rio de Janeiro, Rio de Janeiro, 2018.

ABREU, D. $O$ inglês à flor da pele: investigando a construção discursiva das experiências afetivas em trajetórias de aprendizagem de língua inglesa. 267p. Dissertação (Mestrado em Estudos da Linguagem) - Departamento de Letras, Pontifícia Universidade Católica do Rio de Janeiro, Rio de Janeiro, 2018.

ALLWRIGHT, D. Exploratory Practice: Re-thinking practitioner research in language teaching. Language Teaching Research, 7, 2, 2003, p.113-141.

; HANKS, J. The developing learner. Hampshire, United Kingdom: Palgrave Macmillan, 2009.

ALMEIDA FILHO, J. Conhecer e desenvolver a competência profissional dos professores de LE. In: Contexturas: Ensino Crítico de Língua Inglesa. São Paulo: APLIESP, n.9, 2006. p. 9-19.

ALMEIDA, F.; VIAN JR., O. Estudos em avaliatividade no Brasil: panorama 20052017. SIGNÓTICA , 2018, p. 273-295.

AMORIM, M. A linguística aplicada e os estudos brasileiros: (inter-) relações teórico-metodológicas. RBLA, Belo Horizonte, v. 17, n.1, 2017, p. 1-30.

ANDRÉ, M. Estudo de caso em pesquisa e avaliação educacional. Brasília: Liberlivros, 2005.

ARAGÃO, R. A Dimensão afetiva no ensino e na aprendizagem de L2. Múltiplas perspectivas em Linguística. Uberlândia: EDUFU, 2008, p. 2655-2662.

; CAJAZEIRA, R. Emoções, crenças e identidades na formação de professores de inglês. Revista Caminhos em Linguística Aplicada, v. 16, n.2, 2017. p. 109-133.

BARCELOS, A. "Eu não fiz cursinho de inglês": Reflexões acerca da crença no lugar ideal para aprender inglês no Brasil. In: (org.) Linguística

Aplicada: reflexões sobre ensino e aprendizagem de língua materna e língua estrangeira. Campinas, SP: Pontes, 2011.

Cognição de professores e alunos: tendências recentes na pesquisa de crenças sobre ensino e aprendizagem de línguas. In: BARCELOS, A.; VIEIRAABRAHÃO, M. (Orgs). Crenças e Ensino de Línguas: foco no professor, no aluno e na formação de professores. SP: Pontes, 2006, p.9-12.

Crenças sobre aprendizagem de línguas, Linguística Aplicada e ensino de línguas. Linguagem \& Ensino, Vol. 7, n. 1, 2004, p.123-156.

Desvelando a relação entre crenças sobre ensino e aprendizagem de línguas, emoções e identidades. In: GERHARDT, A.; AMORIN, M.; CARVALHO, A. (Org.). Linguística Aplicada e ensino: língua e literatura. Campinas: Pontes, 2013. p. 153-186.

Identities as emotioning and believing. In: Gary Barkhuizen. (Org.).

Reflections on Language Teacher Identity Research. 1ed., v. 1, New York: Routledge, 2017, p. 145-150. 
; RUOHOTIE-LYHTY, M. Teachers' Emotions and Beliefs in Second Language Teaching: Implications for Teacher Education. In: AGUDO, J. (Org.). Emotions in Second Language Teaching Theory, Research and Teacher Education. New York: Springer, 2018, v. 1, p. 109-124.

Reflexões acerca da mudança de crenças sobre ensino e aprendizagem de línguas. Revista Brasileira de Linguística Aplicada. Belo Horizonte, v. 7. n. 2., 2007, p. 109-38.

; VIEIRA-ABRAHÃO, M. (Orgs). Crenças e Ensino de Línguas: foco no professor, no aluno e na formação de professores. SP: Pontes, 2006.

BASTOS, L.C.; BIAR, L. de A. Análise de narrativa e práticas de entendimento da vida social. DELTA, v. 31, p. 4, 2015.

BASTURKMEN, H. LSP teacher education: Review of literature and suggestions for the research agenda. Ibérica, 28, 2014, p.17 - 33.

BAUMAN, Z. Identidade. Rio de Janeiro: Jorge Zahar, 2005.

BEDRAN, P. F. A formação inicial do professor de línguas no e para o contexto virtual e a construção de comunidades de prática. 306f. Tese (Doutorado em Estudos Linguísticos) - Instituto de Biociências, Letras e Ciências Exatas, Universidade Estadual Paulista Júlio de Mesquita Filho, São José do Rio Preto, 2012.

BEDRAN, P.; SALOMÃO, A. C. Interação de crenças em contexto colaborativo virtual de aprendizagem de línguas. Revista Brasileira de Linguística Aplicada, v. 13,2013 , p. $789-814$

BELMONTE J.; ROSSINI A. Panorama do ensino-aprendizagem de línguas para fins específicos: histórico, mitos e tendências. In: LIMA-LOPES, E.; FISCHER, C.R.; GAZOTTI-VALLIM, M.A. (Orgs.). Perspectivas em Línguas para Fins Específicos: festschrift para Rosinda Ramos. Campinas: Pontes, 2015.

BOMFIM, B.; CONCEIÇÃO, M. P. A formação de professores de línguas estrangeiras no Brasil. In: SILVA, K (Org.). A formação de professores de línguas estrangeiras no Brasil. 1ed. v. 3. Campinas: Pontes, p. 15-48, 2014.

BRASIL. Conselho Nacional de Educação. Resolução CNE/CP, no. 1 de 18 de fevereiro de 2002. Institui Diretrizes e Curriculares Nacionais para a formação de Professores de Educação Básica, em Nível Superior, curso de licenciatura de graduação plena. Diário Oficial da União, Brasília, DF, seção 1, n. 42, 4 de março de 2002.

BUCHOLTZ, M.; HALL, K. "Language and Identity". In: DURANTI, A. (Ed.). A Companion to Linguistic Anthropology. Oxford, Basil Blackwell, 2003.

"Identity and Interaction: A Sociocultural Linguistic Approach". Discourse Studies, v.7, n. 4-5, 2005, p. 585-614.

BUENO, L. A construção de representações sobre o trabalho docente: o papel do estágio. São Paulo: FAPESP, EDUC, 2009.

CANAGARAJAH, A. S. Prying into Safe Houses. In: Costa, P. (Org.). Ethics in Applied Linguistics Research. Abingdon: Routledge, 2015, p. 195-217

CASTRO, S. T. R. O projeto Aprendendo e Ensinando Línguas: Construindo a relação com a teoria na prática de futuros professores de línguas. In: TELLES, J. A. (Org.). Formação inicial e continuada de professores de línguas: Dimensões e ações na pesquisa e na prática. 1ed.Campinas: Pontes, v. 1, 2009, p. 155-165. 
CAVALCANTI, B. A pedagogia de gêneros da escola de Sydney em aulas de inglês para fins específicos: um voo sistêmico-funcional. 155f. Tese (Doutorado em Estudos da Linguagem) - Centro de Ciências Humanas, Letras e Artes, Universidade Federal do Rio Grande do Norte, Natal, 2016.

CAVALCANTI, M. Um olhar metateórico e metametodológico em pesquisa em linguística aplicada: implicações éticas e políticas. In: MOITA LOPES, L. P. (Org.). Por uma linguística aplicada INdisciplinar. São Paulo: Parábola, 2006. p. 233252.

CELANI et al. ESP in Brazil: 25 years of reflection and evolution. Campinas: Mercado de Letras, 2005.

CELANI et al. A abordagem instrumental no Brasil: um projeto, seus percursos e seus desdobramentos. São Paulo: EDUC, 2009.

CELANI, M. A. Revivendo a aventura: desafios, encontros e desencontros. In: CELANI, et al. (Org.). A abordagem instrumental no Brasil: um projeto, seus percursos e seus desdobramentos. São Paulo: EDUC, 2009a, p. 9-33.

Perguntas ainda sem resposta na formação de professores de línguas. In: GIMENEZ, T.; MONTEIRO, M. C. G. (Org.). Formação de professores de línguas na América Latina e transformação social. Campinas, SP: Pontes, 2010. p. 57-67.

Prefácio. In: TELLES, João A. (Org.). Formação inicial e continuada de professores de língua: dimensões e ações na pesquisa e na prática. Campinas, SP: Pontes Editores, 2009b, p. 9-12.

Transdisciplinaridade na Linguística Aplicada no Brasil. In: SIGNORINI, I.; CAVALCANTI, M. C. (Org.). Linguística Aplicada e transdisciplinaridade. Campinas: Mercado de Letras, 2004. p. 129-142.

Introduction. In: CELANI et al. ESP in Brazil: 25 Years of Evolution and Reflection. São Paulo: EDUC e Mercado das Letras, 2005, p.13-26.

COELHO, C; DURÃO, S. Introdução ou como fazer coisas com emoções. Interseções, v. 19, n. 1, Rio de Janeiro, 2017, p. 44-60.

COELHO, $H$. Experiências, emoções e transformações na educação continuada. Tese (Doutorado em Estudos Linguísticos) -Faculdade de Letras, Universidade Federal de Minas Gerais, Belo Horizonte, 2011. 175 f.

CONCEIÇÃO, M. P. Teachers' narratives: revealing experiences and conflicting identities. In: FIGUEREDO, C. J.; MASTRELA-DE-ANDRADE, M. R. (Org.). Ensino de línguas na contemporaneidade: práticas de construção de identidades. Campinas, SP: Pontes, 2013. p. 305-318.

COWIE, N. Emotions that experienced English as a Foreign Language (EFL) teachers feel about their students their colleagues and their work. Teaching and Teacher Education, v. 27, n. 1, p. 235-242, 2011.

CUDDAPAH, J.; CLAYTON, C. Using Wenger's Communities of Practice to Explore a New Teacher Cohort, Journal of Teacher Education, v. 62, n. 1, 2011, p. $62-75$.

CUNHA, T. Estágio de regência em língua inglesa: relato de dificuldades apresentadas por professores em formação inicial. In: NÓBREGA, D (org). Múltiplos Olhares para a Formação de Professores em Línguas Estrangeiras/Adicionais. 1ed. Campina Grande: EDUEPB, 2016, p. 187-227.

D'ANDREA, L. As emoções no processo de aprendizagem de língua inglesa: uma perspectiva sociocultural para ensino de línguas para fins específicos. $235 f$. 
Tese (Doutorado em Linguística Aplicada) - Universidade do Vale do Rio dos Sinos, São Leopoldo, RS, 2016.

DE FINA, A. Discourse and identity. In T.A. Van Dijk (ed.) Discourse studies: A multidisciplinary introduction. London: Sage, 2011. p.263-282.

DENZIN, N. K.; LINCOLN, Y. S. O planejamento da pesquisa qualitativa: Teorias e abordagens. Porto Alegre: Artmed, 2006.

DIAS, S. M. A. Histórias de formação (re)vividas e (re)contadas no estágio supervisionado em língua inglesa. In: NÓBREGA, D (org). Múltiplos Olhares para a Formação de Professores em Línguas Estrangeiras/Adicionais. 1ed. Campina Grande: EDUEPB, 2016, p. 124-155.

DUDLEY-EVANS, T.; ST. JOHN, M.J. Developments in English for specific purposes. A multidisciplinary approach. Cambridge: Cambridge University Press, 1998.

DUSZAK, A. Us and Others: An introduction. In: DUSZAK, A. (org.) Us and Others. Social Identities across languages, discourses and cultures. Amsterdam, Philadelphia: John Benjamins, 2002, p. 1-28.

EGGINS, S. An Introduction to Systemic Functional Linguistics. London: Continuum, 2004.

ERICKSON, F. Qualitative methods in research teaching. In: Wittrock, M. C. (ed.) Handbook or Research on Teaching. A Project of the American Educational Research Association. Third edition. New York: Macmillan, 1986, p. 119-161.

FABRICIO, B. Implementação de mudanças em contextos educacionais: processos de identidade e de negociação identitária. In: BARCELOS, A. (Org.). Linguística Aplicada: Reflexões sobre o ensino e aprendizagem de língua materna e língua estrangeira. Campinas: Pontes, 2011, p. 171-198.

. Linguística Aplicada como espaço de desaprendizagem. In: MOITA LOPES, L. P. (Org.). Por uma linguística aplicada INdisciplinar. São Paulo: Parábola, 2006, p. 45-65

; MOITA LOPES, L. P. Discursos e vertigens: identidades em xeque em narrativas contemporâneas, Veredas, Juiz de Fora, v. 6, n. 2, jul./dez. 2002.

FERRARINI-BIGARELI, M. O ensino de língua inglesa no ensino médio integrado ao técnico do Instituto Federal do Paraná: um contexto idiossincrático. 207 p. (Tese em Educação). Programa de Pós-Graduação da Faculdade de Educação da Universidade de São Paulo, São Paulo, 2016.

FERREIRA, F.; COELHO, H. Emoções e experiências nas escolhas futuras de estudantes do curso de licenciatura em letras. Contexturas, v. 22, 2014, p. 178196.

FERREIRA, T. 'Até hoje espero um feedback da minha professora formadora': representações de uma docente sobre a sua experiência na disciplina de estágio. In: NÓBREGA, D. (Org.). In: NÓBREGA, D (org). Múltiplos olhares para a formação de professores de línguas estrangeiras/adicionais. Campina Grande: EDUEPB, v. 1, 2016, p. 156-186.

FIGUEIREDO, C. A interface do projeto nacional ensino de inglês instrumental e a Universidade Federal de Uberlândia. In: CELANI, M.A.; FREIRE, M.M.; RAMOS, R. (Org.). A abordagem instrumental no Brasil: um projeto, seus percursos e seus desdobramentos. São Paulo: EDUC, 2009. 
FONTANA, N. Autonomia: requisito na formação do professor de línguas para fins específicos. The ESPecialist, v. 29, n. especial, 2008, p. 1-17.

FREIRE, M. Prefácio. In: CELANI, M.; FREIRE, M.; RAMOS, R. (Org.). A abordagem instrumental no Brasil: um projeto, seus percursos e seus desdobramentos. São Paulo: EDUC, 2009.

FUZER, C.; CABRAL, S. R. S. Introdução à gramática sistêmico-funcional em língua portuguesa. Campinas, SP: Mercado de Letras, 2014.

GIDDENS, A. Modernidade e Identidade. Rio de Janeiro: Jorge Zahar, 2002.

GIEVE, S.; MILLER, I.K. "What do we mean by quality of life?" In: GIEVE, S.; MILLER, I.K. (eds.). Understanding the language classroom. Hampshire, United Kingdom: Palgrave Macmillan, 2006.

GIMENEZ, T. (Org.). Trajetórias na formação de professores de línguas. Londrina: Editora UEL, 2002.

; PEREIRA, F. M. Relação universidade / escola na formação de professores de inglês: primeiras aproximações. In: GIMENEZ, T. (Org.). Tecendo as manhãs: pesquisa participativa e formação de professores de inglês. Londrina: Fundação Araucária, 2007. p.7-111.

GOUVEIA, C. Texto e gramática: uma introdução a Linguística SistêmicoFuncional. Matraga, v. 16, n. 24, 2009, p. 13-47.

HALL, S. A identidade cultural na pós-modernidade. Tradução de Tomaz Tadeu da Silva. Rio de Janeiro: DP e A Editora, 2005.

HALLIDAY, M. A. K.; HASAN, R. Language, context and text: aspects of language in a social-semiotic perspective. Oxford: Oxford University press, 1989.

An introduction to functional grammar. London, UK: Arnold, 1994. ; MATTHIESSEN, C. An Introduction to Functional Grammar. Fourth edition. London: Arnold, 2014.

HOLMES, J. L.; CELANI, M. A. Sustainability and local knowledge: the case of the Brazilian ESP Project 1980-2005. English for Specific Purposes, v. 25, 2006, p. 109-22.

HUTCHINSON, T.; WATERS, A. English for specific purposes: a learning centered approach. Cambridge: Cambridge University Press, 1987.

HYPPOLITO, Fernando. Ensino e aprendizagem de inglês para fins Específicos: um estudo de caso. 166f. Dissertação (Mestrado em Linguística e Língua Portuguesa) - Faculdade de Ciências e Letras -Unesp/ Araraquara, 2017

JOHNS, M.A. English for Specific Purposes: The state of the art. (An online interview with Ann M. Johns). International Journal of Language Studies 9, 2015, p. 113-20.

The history of English for Specific Purposes research. In: PALTRIDGE, B., STARFIELD, S. The Handbook of English for Specific Purposes. Chichester: Wiley - Blackwell, 2013, p. 22 - 49.

JOHNSON, K. e GOLOMBEK, S. Mindful L2 Teacher Education: A sociocultural perspective on cultivating teachers' professional development. New York: Routledge, 2016.

JORDÃO, C.; BÜHRER, E. A condição de aluno-professor de língua inglesa em discussão: estágio, identidade e agência. Educação e Realidade. Porto Alegre, v. 38, n. 2, 2013, p. 669-682. 
KIELY, R. English language teacher identity: a framework for teacher learning and professional development. In: EVANS, D. Language and identity. London: Bloomsbury Publishing. 2015, p. 207-228.

KLEIMAN, A. B. Influencing research and research design. In: BARBARA, L.; SCOTT, M. (Org.). Reflections on language learning. 1ed. London: Multilingual Matters, 1994, v. 1, p. 30-40.

KUDIESS, E. As crenças e os sistemas de crenças do professor de Inglês sobre o ensino e a aprendizagem da língua estrangeira no sul do Brasil: sistemas, origens e mudanças. Linguagem e Ensino, v. 8, n. 2, 2005, p.39-96.

KUMARAVADIVELU, B. Toward a postmethod pedagogy. TESOL Quarterly, v.35, n.4, 2001. p.537-60.

LAVE J.; WENGER, E. Situated learning: legitimate peripheral participation. Cambridge, UK: Cambridge University Press, 1991.

LEFFA, V. Aspectos políticos da formação do professor de línguas estrangeiras. In: LEFFA, V. (Org.). O professor de línguas estrangeiras: construindo a profissão. Pelotas: EDUCAT, 2001, p. 333-355.

LIBERALI, F. Atividade social nas aulas de língua estrangeira. São Paulo: Moderna, 2009. 63p.

Formação de professores de línguas: rumos para uma sociedade crítica sustentável. In: GIMENEZ, T.; MONTEIRO, M. C. G. (Org.). Formação de professores de línguas na América Latina e transformação social. Campinas, SP: Pontes, 2010b. p. 71-92.

; MAGALHÃES, M.; ROMERO, T. Autobiografia, diário e sessão reflexiva: atividades na formação crítico-reflexiva de professores. In: BÁRBARA, L.; RAMOS, R. (Org.). Reflexão e ações no ensino-aprendizagem de línguas. Campinas, São Paulo: Mercado de Letras, 2003, p. 131-165.

LIMA, M. Os desafios do ensino de inglês para fins específicos a distância: um estudo de caso. 125f. Dissertação (Mestrado Acadêmico em Letras) Fundação Universidade Federal de Rondônia, 2016.

LIMA-LOPES, E.; FISCHER, C.R.; GAZOTTI-VALLIM, M.A. (Orgs.). Perspectivas em Línguas para Fins Específicos: festschrift para Rosinda Ramos. Campinas: Pontes, 2015.

LÜDKE, M. O lugar do estágio na formação de professores. Educação em Perspectiva, Minas Gerais, v. 4, n. 1, 2013. p. 111-131.

Universidade, escola de educação básica e o problema do estágio na

formação de professores. Formação Docente, Belo Horizonte, v.1, n.1, 2009. p.95-108

; ANDRÉ, M. Pesquisa em educação: abordagens qualitativas. São Paulo: EPU, 2003. $99 \mathrm{p}$.

MAHN, H.; JOHN-STEINER, V. The gift of confidence: a Vygotskyan view of emotions. In: WELLS, G.; CLAXTON, G. Learning for life in the 21st century. Oxford: Blackwell, 2002. p. 46-58

MAKONI, S.; MEINHOF, U. Linguística Aplicada na África: desconstruindo a noção de língua. In: Por uma Linguística Aplicada INdisciplinar. São Paulo: Parábola, 2006, p.191-213.

MARCELO, C. Identidade docente: constantes e desafios. Formação docente, Belo Horizonte, v. 1, n. 1, 2009. p. 109-131. 
MARTIN, J. Beyond Exchange: Appraisal Systems in English. In HUNSTON, S.; THOMPSON, G. (eds.) Evaluation in Text. Oxford: Oxford University Press, 2000, p. 142-175.

.; WHITE, P. The Language of Evaluation: Appraisal in English. New York, Palgrave/Macmillan, 2005. 256 p.

.; ROSE, D. Working with discourse - Meaning beyond the clause.

2nd edition. London and New York: Continuum. 2007.

MATEUS, E. F. Por uma abordagem sócio-histórico-cultural da aprendizagem do professor. In: MACHADO, L.; CRISTOVÃO, V; FURTOSO, V. (Org.). Aspectos da Linguagem: considerações teórico-práticas. Londrina: Idealiza, 2006, p. 95113.

MATTHEWS, P. H. The concise Oxford dictionary of linguistics. Oxford: Oxford University Press, 2014.

MELLO, H. R. Formação cidadã: a formação de conhecimento via parceria universidade-escola. In: GIMENEZ T.; MONTEIRO M. (Org.). Formação de professores na América Latina e transformação social. 1ed. Campinas: Pontes, 2010, v. 1, p. 93-108.

MENEZES, V. et al. Sessenta anos de Linguística Aplicada: de onde viemos e para onde vamos. In: PEREIRA, R. C.; ROCA, P. (Org.). Linguística Aplicada: um caminho com diferentes acessos. São Paulo: Contexto, 2009.

MEURER, J. Gêneros textuais na Análise Crítica de Fairclough. In: MEURER, J. et al. Gêneros: teorias, métodos, debates. São Paulo: Parábola editorial, 2005, p. 81-106.

MEYER, D. Entering the emotional practices of teaching. In: SCHUTZ, P.; ZEMBYLAS, M. Advances in Teacher Emotion Research: The Impact on Teachers' Lives. Dordrecht: Springer, 2009. p. 73-91.

MILLER, I.K. Formação de professores de línguas: da eficiência à reflexão crítica e ética. In: MOITA LOPES, L. P. (Org.). Linguística aplicada na modernidade recente: festschrift para Antonieta Celani. São Paulo: Parábola, 2013, p. 99- 121.

MILLER, J. Teacher identity. In: BURNS, A.; RICHARDS, J. The Cambridge Guide to Second Language Teacher Education. Cambridge: Cambridge University Press, 2009. p. 172-181.

MOITA LOPES, L. P. Da aplicação da linguística à Linguística Aplicada indisciplinar. In: PEREIRA, R. C.; ROCCA, P. (Org.). Linguística aplicada: um caminho com diferentes acessos. São Paulo: Contexto, 2009, p. 11-24.

Linguística Aplicada e Vida Contemporânea: Problematização dos Construtos que têm orientado a pesquisa. In: MOITA LOPES, L. (Org.) Por uma Linguística Aplicada Indisciplinar. São Paulo: Parábola Editorial, 2006b. p. 85108.

Uma Linguística Aplicada Mestiça e Ideológica: interrogando o campo como linguista aplicado. In: MOITA LOPES, L. (Org.) Por uma Linguística Aplicada Indisciplinar. São Paulo: Parábola Editorial, 2006a. p. 13-44.

Fotografias da Linguística Aplicada brasileira na modernidade recente: contextos escolares. In: MOITA LOPES, L. (Org.) Linguística Aplicada na Modernidade Recente. São Paulo: Parábola Editorial, 2013b. p. 15-37.

Gênero, sexualidade, raça em contextos de letramentos escolares.

In: MOITA LOPES, L. P. (Org.) Linguística Aplicada na Modernidade Recente. São Paulo: Parábola Editorial, 2013. p.227-248. 
Socioconstrucionismo: Discurso e Identidades Sociais. In: MOITA

LOPES, L. P. (Org.). Discursos de identidades: discurso como espaço de construção de gênero, sexualidade, raça, idade e profissão na escola e na família. São Paulo: Mercado de Letras, 2003. p. 13-38

MONTEIRO, B.; FONSECA, L.; SOUZA, C.; RIBEIRO, E. Coconstrução das ementas e elaboração de materiais de línguas: um diálogo possível entre as exatas, as técnicas e as humanas. Anais. Apresentação de Trabalho. In: Semana de Química do campus Rio de Janeiro, Rio de Janeiro, 2015.

MONTEIRO, M. Representações de professores de inglês em serviço sobre a Abordagem Instrumental: um estudo de caso. 93 f. (Dissertação de Mestrado) Programa de Pós-Graduação em Linguística Aplicada e Estudos da Linguagem, Pontifícia Universidade Católica de São Paulo, São Paulo, 2009.

MORAES BEZERRA, I. C. Prática Exploratória e a formação inicial do professor reflexivo: "O que vai ficar para os alunos?" Revista Contemporânea de Educação, v. 7, n. 13, jan./jul. 2012, p. 59-76.

; MILLER, I.K. Formação de Professores de Línguas: práticas, teorias, diálogos. In: Soletras. Dossiê 35, 1, 2018, p. 1-10.

MORAES BEZERRA, I. Identidades coletivas: "Isso acaba estourando na mão de quem? De nós, professores". Revista Escrita (PUC-RJ. Online), v. 13, 2011a, p. $1-13$.

Prática de ensino de inglês: quando a teoria e a prática buscam o diálogo. In: Anais do I CLAFPL. Florianópolis: Universidade Federal de Santa Catarina, 2006, p. 729-741.

Prática Exploratória, espaços formativos e a educação crítica de professores de inglês: o olhar híbrido de uma professora formadora. Revista X, v. 2, 2011b, p. 76- 96.

MOURA FILHO, A.C.L. Basta de clamarmos inocência: a formação reflexiva do professor contemporâneo de línguas. In: DANIEL, F. G., et al. A Formação de Professores de Línguas: novos olhares. 11. ed. Campinas: Pontes Editores, v. 1, 2011, p. 49-72.

MURPHEY, T.; PROBER, J.; GONZALES, K. Emotional belonging precedes learning. In: BARCELOS, A.; COELHO, H. (Org.). Emoções, reflexões e (trans)form(ações) de alunos, professores e formadores de professores de línguas. Campinas: Pontes, 2010, p.43-56.

NASCIMENTO, K. A postura crítico-reflexiva de uma professora em formação frente aos desafios inerentes às experiências durante a disciplina de estágio Supervisionado: um estudo de caso. In: NÓBREGA, D. (Org.). In: NÓBREGA, D (org). Múltiplos Olhares para a Formação de Professores de Línguas Estrangeiras/Adicionais. 1. ed. Campina Grande: ADUEPB, 2016, p. 46 -70.

NÓBREGA, A. N. Narrativas e avaliação no processo de construção do conhecimento pedagógico: abordagem sociocultural e sociossemiótica. 244 p. Tese (Doutorado em Estudos da Linguagem) - Departamento de Letras, Pontifícia Universidade Católica do Rio de Janeiro, Rio de Janeiro, 2009.

OLIVEIRA, B.; BARCELOS, A. M. F. Identidade e motivação de professores préserviço de Inglês e suas crenças sobre ensino e aprendizagem de língua inglesa: um estudo longitudinal. Revista Contemporânea de Educação, v. 7, n.13, 2012, p. 127-153. 
OLIVEIRA, E. Formadores de professores de língua inglesa: uma experiência de colaboração e reflexão. 233 p.Tese (Doutorado em Linguística Aplicada) Universidade Federal de Minas Gerais, Belo Horizonte, 2008.

OLIVEIRA, H. Esculpindo a profissão professor: experiências, emoções e cognições na construção as identidades docentes de licenciandos em Letras. 301p. Tese (Doutorado em Letras e linguística) - Departamento de Letras, Universidade Federal de Goiás, Goiânia, 2013.

OLIVEIRA, P. Brazilian EFL teachers' experiences in public and private schools: different context with similar challenges. In: KALAJA, P.; MENEZES, V.; BARCELOS, A. M. F. (Org.). Narratives of learning and teaching EFL. London: Palgrave Macmillan, 2008. p. 64-79.

PAIVA, V. A formação do professor para uso da tecnologia. In: SILVA et al.(Org.). A formação de professores de línguas: Novos olhares- volume II. 1ed.: Pontes, 2012. p. 209-230.

PARKINSON, J. English for science and technology. In: PALTRIDGE, B., STARFIELD, S. The Handbook of English for Specific Purposes. Chichester: Wiley - Blackwell, 2013, p. 155 - 173.

PENNYCOOK, A. Uma Linguística Aplicada Transgressiva. In: MOITA LOPES, L. P. (Org.). Por uma linguística aplicada INdisciplinar. São Paulo: Parábola, 2006. p.67-84.

PERINE, C. M. "Inglês em Rede": crenças e motivação de aprendizes em um curso a distância. 233 p. Dissertação (Mestrado em Estudos Linguísticos) Universidade Federal de Uberlândia, Uberlândia, 2013.

PIMENTA, S. G. Professor reflexivo: construindo uma crítica. In: PIMENTA, S. G.; GHEDIN, E. (Org.). Professor reflexivo no Brasil: gênese e crítica de um conceito. São Paulo: Cortez, 2002. p. 12-52. .; LIMA, M. S. Estágio e docência. São Paulo: Cortez, 2012.

PRADO, G.; SOLIGO, R. Memorial de formação: quando as memórias narram a história da formação. In: PRADO, G.; SOLIGO, R. (Org.). Porque escrever é fazer história: revelações, subversões, superações. Campinas, SP: Graf, 2005, p.4762.

QUADROS-ZAMBONI, A. S. Apendicite formativa nos cursos de Letras: reflexões sobre a formação do professor de inglês. 1. ed. Campinas: Pontes Editora, 2015. v. 1. 139p.

RAJAGOPALAN, K. Política de ensino de línguas no Brasil: história e reflexões prospectivas. In: MOITA LOPES, L. P. (Org.). Linguística aplicada na modernidade recente: festschrift para Antonieta Celani. São Paulo: Parábola, 2013, p. 143-161.

Repensar o papel da linguística aplicada. In: MOITA LOPES, L. P. (Org.). Por uma linguística aplicada INdisciplinar. São Paulo: Parábola, 2006. p. 149-166.

RAMOS, R. A história da abordagem instrumental na PUCSP. In: CELANI, M.A.A.; FREIRE, M.M.; RAMOS, R. (Org.). A abordagem instrumental no Brasil: um projeto, seus percursos e seus desdobramentos. São Paulo: EDUC, 2009a. p. 3545.

ESP in Brazil: History, new trends and challenges. In: KRZANOWSKI, M. (ed.). English for Academic and Specific Purposes in Developing, 
Emerging and Least Developed Countries. Canterbury: IATEFL, 2008. p. 6884.

Gêneros textuais: uma proposta de aplicação em cursos de inglês para fins específicos. The ESPecialist, v. 25, n. 2, 2004, p. 107-129.

Uma experiência de formação on-line de professores de inglês para fins específicos. In: SILVA et al.(Org.). A formação de professores de línguas: Novos olhares- volume II. 1ed.: Pontes, 2012, p. 229-258.

Design de material didático online: reflexões. In: SOTO, U.; MAYRINK, M.F.; GREGOLIN, G.V. (Orgs.). Linguagem, educação e virtualidade. São Paulo: UNESP, 2009b, p. 93-115.

Instrumental no Brasil: a desconstrução de mitos e a construção do futuro. In: FREIRE, M.M.; ABRAHÃO, M.H.V.; BARCELOS, A.M.F. (Org.). Linguística Aplicada e Contemporaneidade. Campinas: Pontes, 2005, p. 109123.

; FREIRE, M. ESPTEC: Formação de Professores e Multiplicadores de Ensino-Aprendizagem de Inglês Instrumental para o Sistema de Educação Profissional de Nível Técnico. In: TELLES, J (Org.). Formação inicial e continuada de professores de línguas. Campinas, SP: Pontes Editores, 2009, p. 29-40.

REICHMANN, C. L. 'A professora regente disse que aprendeu muito': a voz do outro e o trabalho do professor iniciante no estágio. Raído (Online), v. 8, 2014. p. 33-44.

REIS, C.; SANTOS, W. Experiências marcantes no estágio supervisionado em uma narrativa de um estudante de Prática de Ensino de Português / Línguas estrangeiras da Faculdade de Educação da UFRJ. Anais do SILEL. V.3, N.1. Uberlândia, EDUFU, 2013.

Uma tessitura de relações: uma ponte entre o incidental do saber e a comunidade de prática. In: SANTOS, W.; REIS, C. (Org.). Formação de Professores de línguas em múltiplos contextos: construindo pontes de saberes e agenciamentos. 1 ed. Campinas - SP: Pontes, 2015, v. 1, p. 15-26.

RESENDE, V. M. Decolonizar os estudos críticos do discurso: por perspectivas latino-americanas. Conferência proferida no XII Congresso Internacional da Associação Latino-Americana de Estudos do Discurso - ALED. Aula Magna, Centro de Extensão, em 18 de outubro de 2017. Santiago: Universidad Católica de Chile, 2017.

REZENDE, C.; COELHO, M. Antropologia das Emoções. Rio de Janeiro: Editora Fundação Getúlio Vargas., 2010, 136 p.

ROCHA SILVEIRA, F. Ressignificando a ansiedade na aprendizagem e uso de línguas estrangeiras através das crenças: um estudo exploratório. 300 p. Tese (Doutorado em Estudos da Linguagem) - Departamento de Letras, Pontifícia Universidade Católica do Rio de Janeiro, 2012.

ROJO, R. Fazer Lingüística Aplicada em perspectiva sócio-histórica: privação sofrida e leveza de pensamento. In: MOITA LOPES, L. P. (Org.). Por uma linguística aplicada INdisciplinar. São Paulo: Parábola, 2006. p. 253-276.

SALIÉS, T. Prefácio. In: Formação de professores de línguas em múltiplos contextos: construindo pontes de saberes e agenciamentos, Pontes: 2015, p. 1114. 
SANTOS, L. Formação docente e prática pedagógica: o professor e o aluno de língua estrangeira em foco. Calidoscópio. v. 8. n.1, 2010. p. 49-64.

SCHLEE, M. B; NÓBREGA, A. N.; VIAN JR, O.; Linguística Sistêmico Funcional como ferramenta para a compreensão de diferentes práticas discursivas. No prelo.

SCHÖN, D. Educando o profissional reflexivo. Um novo design para o ensino e a aprendizagem. Porto Alegre: Artes Médicas Sul, 2000.

SCOTT, M. Critical reading needn't be left out. In: CELANI, M. et al (Orgs). ESP in Brazil: 25 years of evolution and reflection. Campinas: Mercado das Letras. 2005. p.123-142.

SERRÃO, M. Superando a racionalidade técnica na formação: sonho de uma noite de verão. In: PIMENTA, S. G.; GHEDIN, E. (Org.). Professor reflexivo no Brasil: gênese e crítica de um conceito. São Paulo: Cortez, 2002. p. 151-162.

SILVA, K.; SANTOS, L.; JUSIANA, O. Entrevista com Kanavillil Rajagopalan: ponderações sobre linguística aplicada, política linguística e ensinoaprendizagem. Revista de Letras Norte@mentos. Revista de Estudos Linguísticos e Literários., 2011.

SNOW, D. Collective Identity and Expressive Forms. eSchollarship Repository, University of California, http://repositories.cdlib.org/csd/01-7, 2001.

SOUZA, C. F. (Re) pensando o ensino de língua inglesa no Instituto Federal de Educação, Ciência e Tecnologia Fluminense: propostas para além do ensino de língua estrangeira instrumental. InterSciencePlace, n. 28, v.1, jan./mar. 2014.

SOUZA, C. Questionando textos multimodais: produção e uso de material didático para leitura crítica nas aulas de inglês. Pesquisas em Discurso Pedagógico (Online), v. 1, 2016.

.; RIBEIRO, E.; FONSECA, L.; MENEZES, R. A vez dos alunos na revisão das ementas de inglês para fins específicos no ensino médio e técnico. In: XI JIT - Jornada Interna de Iniciação, Tecnológica e Científica. Anais. Rio de Janeiro: IFRJ, 2017.

SOUZA, M. Avaliações e crenças em uma sala de aula de inglês para fins específicos sob o prisma sociocultural e sociossemiótico. 279p. Tese (Doutorado em Estudos da Linguagem) - Departamento de Letras, Pontifícia Universidade Católica do Rio de Janeiro, Rio de Janeiro, 2016.

SOUZA, S. Ressignificando o ensino de inglês instrumental em contexto profissional de nível médio: uma proposta baseada em sequência didática. $149 f$. Dissertação (Mestrado em Linguística Aplicada). Departamento de Línguas Estrangeiras e Tradução. Universidade de Brasília, Brasília, 2013.

STAKE, R. E. Case studies. In: DENZIN, N. K.; LINCOLN, Y.S. (Ed.). Handbook of qualitative research. Thousand Oaks, California: Sage, 2000. p. 435-454.

SWALES J. Envoi. In: BELCHER, D., JOHNS, A.; PALTRIDGE, B. (eds.). New Directions in English for Specific Purposes Research. Ann Arbor: University of Michigan Press, 2014. p. 271-274

Episodes in ESP: a source and reference book on the development of English for science and technology. Oxford: Pergamon Press, 1985.

THOMPSON, G. Introducing Functional Grammar. London: Arnold, 2014a.

Affect and emotion, target-value mismatches, and Russian dolls.

Refining the APPRAISAL model. In: THOMPSON, G.; ALBA-JUEZ, L. (eds).

Evaluation in context. Amsterdam/Philadelphia: John Benjamins, 2014b. 418 p. 
TROTMAN, W. Enacting exploratory practice principles: mentoring language teaching professionals. In: Dikilitaş K., Hanks J. (eds). Developing Language Teachers with Exploratory Practice. Cham: Palgrave Macmillan, 2018, p 39-59.

TUROLO-SILVA, A. O papel dos fatores contextuais na relação teoria-prática de ensino aprendizagem de línguas estrangeiras e na construção da interação em sala de aula. In: SILVA et al. (Org.). A Formação de Professores de Línguas: Novos Olhares, v. III. 1ed. Campinas: Pontes Editora, 2014, p. 195-222.

VALSECHI, M. Afinal, o que é o estágio supervisionado? De labirinto a entrelugar: o estágio proposto pela Universidade na visão dos estagiários. $298 f$. Tese (Doutorado em Linguística Aplicada) - Universidade Estadual de Campinas, Instituto de Estudos da Linguagem. Campinas, SP, 2016.

VIAN JR, O. A análise de necessidades no ensino de inglês em contextos profissionais. the ESPecialist, vol. 29, no 2, 2008, p. 39-158.

A Formação Inicial do Professor de Inglês para Fins Específicos. In: LIMA-LOPES, E.; FISCHER, C.R.; GAZOTTI-VALLIM, M.A. (Orgs.). Perspectivas em Línguas para Fins Específicos: festschrift para Rosinda Ramos. Campinas: Pontes, 2015, p. 187-208.

Avaliatividade, engajamento e valoração. D.E.L.T.A., v. 28, n.1, São Paulo, 2012. p. 105-128.

; SOUZA, A.; ALMEIDA, F. (org.). A linguagem da avaliação em língua portuguesa: estudos sistêmico-funcionais com base no Sistema da Avaliatividade. São Carlos, Pedro e João Editores, 2011.

; SOUZA, A. Linguística Sistêmico-Funcional e suas contribuições à pesquisa linguística no contexto brasileiro. Odisseia, Natal, RN, v. 2, n. esp., 2017, p. 185-203.

VIEIRA-ABRAHÃO, M.H. A formação inicial do professor de língua estrangeira: parceria universidade escola. In: ORTIZ, M.; SILVA, K. (Org.). Linguística Aplicada: Múltiplos Olhares. 1ed.Campinas: Pontes, 2007, v. 1, p. 155-166.

. Prefácio. In: NÓBREGA, D. (Org.). In: NÓBREGA, D (org). Múltiplos Olhares para a Formação de Professores de Línguas Estrangeiras/Adicionais. 1. ed. Campina Grande: ADUEPB, 2016. p. 8-13.

Teoria e prática na formação pré-serviço do professor de língua estrangeira. In: GIMENEZ, T. (Org.). Trajetórias na formação de professores de línguas. Londrina: Editora da UEL, 2002. p. 59-76.

VYGOTSKY, L. S. A formação da mente. São Paulo, SP: Martins Fontes., 1998.

WENGER, E. Communities of Practice. Learning, Meaning, and Identity. Cambridge: Cambridge University Press, 1998.

ZABALZA, Miguel. Diário de Aula: um instrumento de pesquisa e desenvolvimento profissional. Porto Alegre: Artmed, 2004.

ZEICHNER, K. M. Uma análise crítica sobre a "reflexão" como conceito estruturante na formação docente. Educação e Sociedade, Campinas, v. 29, n. 103, 2008. p. 535-554

ZEMBYLAS, M. Beyond teacher cognition and teacher beliefs: the value of the ethnography of emotions in teaching. International Journal of Qualitative Studies in Education, v. 18, n. 4, 2005, p. 465-487.

Emotions and teacher identity: a poststructural perspective. Teachers and Teaching: theory and practice. 9 (3), 2003, p. 213-238. 
The emotional characteristics of teaching: Teaching and Teacher Education, v. 20, 2004, p. 185-201.

The power and politics of emotions in teaching. In: SCHUTZ, P; PECKRUN, R. (eds). Emotions in education. New York: Academic, 2007, p. 293309.

; SCHUTZ, P.A. Advances in Teacher Emotion Research: The Impact on Teachers' Lives. New York: Springer, 2009, p. 3-73. 


\section{Anexos}

\section{Anexo 1 - Convenções de transcrição*}

\begin{tabular}{|c|c|}
\hline$\ldots$ & pausa não medida \\
\hline$(2.5)$ & pausa medida \\
\hline$()$. & Pausa de menos de dois décimos de segundo \\
\hline$\uparrow$ & entonação ascendente \\
\hline$\downarrow$ & entonação descendente \\
\hline$?$ & entonação ascendente para se construir uma pergunta \\
\hline , & entonação de continuidade \\
\hline- & parada súbita \\
\hline$=$ & elocuções contíguas, enunciadas sem pausa entre elas \\
\hline---- & silabação \\
\hline sublinhado & ênfase \\
\hline MAIÚSCULA & fala em voz alta ou muita ênfase \\
\hline$>$ palavra $<$ & fala mais rápida \\
\hline$<$ palavra $>$ & fala mais lenta \\
\hline${ }^{\circ}$ palavra ${ }^{\circ}$ & fala em voz baixa \\
\hline : ou :: & alongamentos \\
\hline[ & início de sobreposição de falas \\
\hline ] & final de sobreposição de falas \\
\hline() & fala não compreendida \\
\hline (palavra) & fala duvidosa \\
\hline$(())$ & comentário do analista, descrição de atividade não verbal \\
\hline “palavra” & fala relatada \\
\hline hh & aspiração ou riso \\
\hline
\end{tabular}

* Adaptadas dos estudos da Análise da Conversa (SACKS; SCHEGLOFF; JEFFERSON, 1974), com incorporações de Loder e Jung (2009). 


\section{Anexo 2 - Perguntas e respostas iniciais}

Nesse momento que você inicia o estágio de inglês no IFRJ, gostaríamos de saber o que você pensa sobre alguns pontos.

1. Como é desenvolvido o ensino de inglês no ensino médio técnico?

Imagino que o foco seja que os alunos aprendam termos relacionados a sua área de interesse e saibam lidar com situações em que a língua inglesa seja usada.

2. O que você entende por LinFE (Línguas para Fins Específicos)?

Por enquanto ainda não sei muito sobre o assunto, mas imagino que envolva vocabulário e termos técnicos voltados para uma área específica.

3. Quais são suas expectativas quanto ao estágio e a sua vivência no IFRJ? Espero aproveitar ao máximo a minha experiência, ter um bom convívio com os alunos e professores com os quais tiver contato e auxiliar os alunos no que precisarem.

4. Você acha que o estágio pode influenciar sua formação docente de alguma forma? Por que (não)?

Sim, porque este é meu primeiro estágio na área docente e gostaria de saber se é algo que me vejo fazendo no futuro. 


\section{Anexo 3 - Diário 1}

Minha experiência como estagiária no instituto até o momento tem sido melhor do que o esperado. Antes de entrar para a faculdade de Letras (e até mesmo durante a maior parte da minha graduação, mesmo fazendo licenciatura) nunca tive a intenção de ser professora porque achava que não daria conta de tanta responsabilidade e porque tinha medo de como os alunos me tratariam. Mas por enquanto todas as turmas nos trataram bem e os alunos que falaram comigo foram amistosos. Fiquei feliz quando me fizeram perguntas porque não pensei que poderia ensinar algo para alguém e agora vejo que isso é possível.

Também me sinto melhor por estar numa escola técnica porque assim saio do lugar comum (gramática) e vejo outra realidade. É uma experiência muito rica porque apesar de ter tido poucas aulas, já aprendi coisas interessantes (como fazer shampoo para cabelo). Acho que por causa disso tenho mais disposição para as aulas do que teria se fosse uma escola "tradicional" (por falta de palavra melhor).

A verdade é que tudo isso é novo para mim, por ser meu primeiro estágio. Por muito tempo a ansiedade me atrapalhou, inclusive me tirando algumas oportunidades de trabalho em cursos de inglês. Sentia muita pressão porque todos que conheço na faculdade já davam aula e eu não. Mas cada um tem seu próprio caminho e hoje em dia não me preocupo mais com isso (pelo menos não tanto quanto antes) porque acredito que para uma pessoa como eu é importante que as coisas aconteçam gradualmente, para que eu me acostume com minhas futuras funções, ao invés de ter que me "virar" sozinha.

Em relação as turmas em si, percebi que gostei bastante das turmas de Meio Ambiente, tanto a da quinta quanto a de sábado. Sinto que os alunos dessas turmas são mais receptivos em relação a mim, mas é muito cedo para dizer, já que ainda não tive muitas oportunidades de me enturmar com os alunos em geral.

Também gosto da localização da escola. Quando se mora longe, essas coisas fazem muita diferença no dia-a-dia. Só tenho que pegar um ônibus e ele para bem em frente à escola. Só gostaria que o elevador estivesse funcionando porque subir tantas escadas é um pouco doloroso.

No mais, tento fazer com que o estágio seja uma boa experiência para mim como pessoa, estudante de Letras e futura professora. Inclusive, quando a hora chegar e se eu conseguir, gostaria de lecionar em uma escola técnica (o que é engraçado agora porque na escola nunca fui fã de química ou biologia, por exemplo). 


\section{Anexo 4 - Diário sobre a regência}

Nesse semestre, eu acompanhei cinco turmas: BM 131 e MAM 241 (CT) às quintas-feiras com a professora Carla; FM 151, AM 241 e MAM 251 aos sábados com a professora Maria. Achei que seria melhor decidir em qual turma faria minha prova-aula depois de acompanhá-las por algumas semanas. Todas as especializações são interessantes e todas as turmas foram agradáveis, então minha escolha seria mais natural se fosse feita ao longo do estágio. Por fim, escolhi a turma FM 151. O principal motivo por trás dessa escolha foi eu ter feito duas coparticipações nessa turma antes da prova-aula. Por estarem mais familiarizados com a minha presença naquela posição, o fato de eu estar dando a aula naquele dia não causaria grande estranhamento para os alunos e assim eles poderiam se concentrar na aula em si. Com a turma escolhida, pude dar início ao processo de elaboração da prova-aula.

A primeira informação que recebi é que teria 50 minutos de aula e que o resto seria usado para que a professora da disciplina na faculdade (Flávia), a professora regente (Maria) e eu conversarmos sobre minha avaliação. Apesar de ser uma pessoa de poucas palavras, fiquei receosa porque tinha medo de não conseguir calcular o tempo adequado para cada passo e acabar passando do horário estipulado. A segunda informação que recebi é que o tema previsto para a aula do dia da regência era "Homeopahy, phytotherapy and allopathy" e que essa seria a última aula deles antes da última prova. Minha primeira atitude foi pesquisar sobre essas medicinas na internet porque não sabia exatamente do que elas se tratavam. O primeiro momento foi complicado. Não conseguia encontrar o significado de alopatia e não entendia a forma como a homeopatia funcionava. Pensei que talvez esse tema simplesmente não fosse pra mim e cogitei a possibilidade de pedir à professora pra mudá-lo, caso possível (já que fizemos algo semelhante uma vez na turma MAM 251). Decidi não fazer isso e ficar com o tema. Se depois eu achasse que não conseguiria, falaria com a professora, mas até lá, encararia a situação como um desafio. Fui, então, procurar textos acadêmicos em inglês sobre as medicinas. De novo, minha busca foi frustrada. Meu próximo passo foi contatar uma amiga estudante de Saúde Pública na Polônia. Ela não estuda a medicina alternativa em si na sua graduação, porém tinha mais acesso à textos sobre o assunto do que eu. Ela me enviou todos os artigos que pôde encontrar e isso me deu segurança para traçar um plano concreto do que eu faria a seguir.

Antes de voltar aos artigos, assisti a uma oficina sobre produção de material didático dada pelo professor Marcos Carnavale no IFRJ. Por ser algo que eu nunca fiz antes, a oficina foi muito esclarecedora e me ajudou a pensar em qual tipo de exercício eu poderia colocar nos textos que usaria na prova-aula. Depois, conversei com o professor Marcos sobre um dilema que estava enfrentando: como cobriria três assuntos diferentes em 50 minutos? Ele me deu, então, a ideia de dividir a turma em três grupos. Fazer uma atividade em grupo já estava nos meus planos; a turma era pequena e os alunos pareciam ter uma relação amistosa. Mas dividir os assuntos entre os grupos foi ideia dele e eu achei que seria uma boa experiência, visto que na hora em que os alunos dissessem suas respostas em voz alta, os outros teriam que prestar atenção no que eles diziam, já que não teriam lido os textos eles mesmos.

Chegando em casa, meu primeiro passo foi ler todos os artigos, um por um, a fim de encontrar algo que desse um bom panorama de cada uma das três medicinas. Nessa fase, a maior adversidade que tive foi não encontrar nenhum artigo que dissertasse sobre qualquer uma delas por mais de um curto parágrafo. Todos eles eram sobre a medicina em questão relacionada ao tratamento de alguma doença específica, geralmente em defesa da medicina alternativa, tentando comprovar sua eficácia. Isso, inclusive, foi outro problema. Tudo que 
encontrei na internet sobre alopatia rebaixava a homeopatia e tudo sobre homeopatia e fitoterapia rebaixava a alopatia. Inclusive, uma ideia que tive foi colocar uma charge no final da apresentação de PowerPoint ou de algum texto dos exercícios, mas por esse motivo não pude fazê-lo. Sei que nenhum texto é imparcial, mas os textos em geral eram exageradamente óbvios em seus posicionamentos e eu precisava de algo que simplesmente explicasse do que as medicinas se tratavam, mencionando os pontos positivos e negativos de cada uma sem desmerecer as outras. Esses pontos seriam relatados pelos alunos no exercício, em que haveria uma tabela para que eles completassem com essas informações. No fim, essa parte da aula ficou planejada assim: três textos, cada um sobre uma das medicinas que eram o tema da aula. Os textos seriam, na verdade, uma junção de dois ou três parágrafos de artigos diferentes. Eu dividiria a turma em três grupos e cada grupo seria responsável por um texto. O exercício seria uma tabela em que eles deveriam responder sobre o que se tratava a medicina de seu texto, assim como os pontos positivos e negativos dela. Depois, eles responderiam o que colocaram em voz alta, dividindo, assim, suas respostas com a turma toda.

A ideia para a parte seguinte também veio da leitura dos artigos que minha amiga mandou. Um deles era sobre o uso medicinal da marijuana e isso me deu a ideia de trazer essa discussão para a aula. Não usei o texto em si porque também falava sobre uma doença específica, mas não foi difícil encontrar um que fosse sobre a história dessa discussão no Brasil. O debate sobre a legalização da marijuana no Brasil é muito popular e acontece há muitos anos, por isso pareceu ser de grande relevância para os alunos. Achei que a discussão se encaixaria na proposta da pedagogia crítica e dos documentos oficiais sobre a educação no Brasil que estudamos em Didática Especial e ao longo da graduação em geral. Como estudantes de Farmácia, acredito que a visão dos alunos em relação a essas questões tenha um grande peso, seja para a legalização ou proibição do uso de qualquer substância de forma legal. Acredito, até, que essa discussão poderia ser feita em qualquer escola; talvez os alunos não teriam o mesmo nível de especificidade em seu conhecimento de mundo, mas a questão social do debate é algo que interessa à todos nós brasileiros. E, de forma geral, como cidadãos e alunos do ensino médio, é importante que eles saibam se posicionar em relação à temas delicados e a escola é um dos espaços em que eles podem exercitar isso. A verdade é que já o fazem nos intervalos, nos corredores...mas essa é uma discussão muito rica para ficar escondida nos bastidores e acho que a escola fazer uso disso seria de grande benefício pra formação dos alunos.

Então, como eu disse anteriormente, para essa parte da aula escolhi um texto que falava sobre a legalização/proibição da marijuana num contexto histórico. Achei que seria pertinente mostrar também um vídeo sobre o assunto. O único que encontrei que parecia sensato passar em uma aula como aquela falava apenas sobre os benefícios. Gostaria de algo que falasse sobre as possíveis consequências negativas também, mas não foi possível achá-lo. Mas, pelo menos, o vídeo em questão era todo legendado, fator decisivo para minha escolha.

Com essas duas partes preparadas, finalmente pude começar a apresentação de PowerPoint que daria no início da aula. Para a minha fala e o texto dos slides, quis usar algo simples e, por isso, deixei os textos de sites da internet pra essa parte. Gostaria de ter feito algo um pouco mais vivo, mais colorido, usado o recurso visual a meu favor. Mas acabei seguindo uma linha mais simples pois parecia mais apropriado pro tema da aula.

Para o warm up, minha primeira ideia foi perguntar aos alunos o que eles tomam quando estão doentes ou o que eles recomendariam à alguém que estivesse. Falaria, talvez, das minhas próprias experiências. Mas a professora Maria me deu outra ideia, que seria mostrar aos alunos medicações pertencentes 
a cada uma das três medicinas e pedir que eles as separassem em três grupos, dizendo depois quais grupos seriam. Para o debate que aconteceria na última parte da aula, sobre a legalização da marijuana, a professora Flávia me deu a ideia de dividir o quadro em duas colunas como "sim/não", para que eu anotasse os argumentos dos alunos e assim eles ficassem mais claros.

Escrever o plano de aula foi uma das últimas coisas que eu fiz. Queria me sentir livre pra planejar a aula criativamente e achei que se escrevesse o plano antes de começar, acabaria me prendendo demais à ele ou modificando ele demais, me confundindo no final. Pareceu mais sensato tratar o plano como uma espécie de guia do que eu faria na aula depois de planejada. Pra mim, a maior função e o maior desafio do plano é justificar o porquê de estarmos fazendo aquilo que estamos fazendo. Creio que as coisas precisam ter uma motivação clara por trás delas para que os alunos possam se engajar nas atividades. Também tenho dificuldade em nomear as coisas e a professora Carla me ajudou nesse sentido, revisando o plano de aula comigo.

Por fim, escrevi um script com as minhas falas. É algo que sempre faço para minhas apresentações orais porque tenho dificuldade de falar em público e não conseguiria falar naturalmente na hora ou improvisar caso esquecesse algo. É uma medida de segurança; no final sempre consigo falar sem ler, porém, me sinto mais segura sabendo que o script está perto de mim.

Minha prova-aula foi, em geral, de acordo com o planejado. Deveria ter dedicado mais tempo ao planejamento do $1^{\circ}$ passo, o warm-up, porque ele levou mais tempo do que o previsto, o que me levou a passar do tempo determinado pro encerramento da aula. Mas depois disso, a aula seguiu sem grandes problemas. O 2ำ passo foi a apresentação de PowerPoint e a parte da aula em que eu mais falaria. Li o texto dos slides e também fiz comentários sobre o assunto da aula. Tentei comunicar minha explicação de forma clara e simples e acredito que tenha conseguido. Nos $3^{\circ}$ e $4^{\circ}$ passos, me atrapalhei um pouco na hora de distribuir os textos entre os alunos. Como cada um teria três textos nessa atividade, me confundi e para dois ou três alunos entreguei apenas dois. Como acontece durante exercícios, às vezes os alunos começaram a conversar sobre outros assuntos. Apesar de ter de controlar o tempo, não me opus a isso porque considero algo natural e benéfico pra interação social entre os alunos. Fora isso, a atividade também correu dentro do previsto, com a exceção de que eu esperava que eles fossem responder em português, mas responderam em inglês. O $5^{\circ} \mathrm{e}$ último passo poderia ter sido mais desenvolvido no plano de aula. Mas a execução em si também correu muito bem. A participação da turma foi excelente em todos os passos e nesse foi fundamental.

Uma coisa que valorizo muito é a auto avaliação e a autorreflexão em geral. É importante que o aluno reflita sobre seu próprio desempenho, levando em conta as atitudes positivas que teve e também as que pode melhorar no futuro. Apesar de não fazer parte da avaliação oficial, achei muito válido que as professoras tenham me perguntado que nota me daria. Também considero positivo termos mais de uma professora nos avaliando, para que assim a nota não seja centralizada em uma única perspectiva. Em relação ao item Planejamento escrito da aula, houve um esforço real da minha parte para trazer um material de qualidade para os alunos e estudar um assunto que antes era totalmente desconhecido pra mim com boa vontade e mente aberta. Hoje, teria começado minha pesquisa mais cedo e procuraria mais fontes; pretendo ser uma pessoa mais organizada nesse sentido daqui em diante. Também considerei minha nota justa em relação ao item Desenvolvimento da aula. Tentei levar algo adequado ao nível cognitivo dos alunos, sem subestimá-los ou usar algo que estivesse fora de sua realidade e isso contribuiu para o funcionamento da aula. Também tentei estar presente entre os alunos e mostrar-me solícita. Durante o debate no final da aula, fiz o que pude para validar todas as vozes pois acredito que o importante não é 
necessariamente concordarmos, mas sim refletir de forma crítica e respeitosa. Como futura professora, quero incentivar os alunos a fazerem isso como parte da minha prática docente. Minha avaliação foi feita pelas professoras Flávia e Carla; Maria, minha regente, não pôde comparecer no dia.

A prova-aula foi um momento muito bonito da minha formação. Considerando o fato de que foi a primeira aula que eu dei na vida, acho que as coisas foram até melhor do que eu esperava. Pensei que fosse ficar muito nervosa, mas na hora não fiquei. Foi uma aula agradável e acho que consegui fazer um trabalho que resumiu o estágio como um todo. 


\section{Anexo 5 - Memorial de Estágio}

Minha experiência no estágio foi a parte mais significativa da reta final da minha graduação. Amadureci muito nesses semestres e o estágio foi essencial nesse processo que, de forma geral, foi extremamente positivo, útil e recompensador.

Estagiei em três escolas e acompanhei várias turmas e professoras, conhecendo pessoas que contribuíram para minha transição não só de estagiária para professora, mas também de adolescente para adulta.

O primeiro estágio que fiz foi com as turmas de inglês no instituto. Por não ter tido uma boa experiência na minha formação escolar, evitei a disciplina Prática de Ensino por alguns semestres porque tinha medo de voltar a uma escola. Mas cheguei a um ponto da graduação em que iniciar essa disciplina era inevitável, então me inscrevi. Nos meses anteriores, tive muita ansiedade e cheguei a ter pesadelos.

Tinha medo de como os alunos me tratariam. Assim, fui para o instituto sem saber o que aconteceria. O primeiro momento foi um pouco desconcertante porque nunca tinha ouvido falar sobre inglês para fins específicos antes. Minha prioridade em sala de aula é conseguir ajudar os alunos e por isso fiquei preocupada de não poder fazê-lo por minha falta de conhecimento na área deles. As turmas que acompanhei foram de bioquímica, alimentos, farmácia e meioambiente. A ciência era algo tão distante da minha realidade que meu primeiro pensamento é que ficaria perdida em meio a tantos termos técnicos e assuntos que são difíceis para mim. Mas rapidamente percebi que não seria assim. Conseguia entender o que se passava nas aulas e apesar de não ter muito contato com os alunos, pude ajudá-los quando precisavam. Aos poucos, fui me interessando mais e mais pelo IFE. Como não aprendi inglês de uma forma tradicional, e de forma bastante autônoma, me adaptei facilmente à abordagem porque: envolve a pesquisa de temas interessantes (e, consequentemente, temas que incitam pensamento crítico); retrata a gramática de forma sútil, não sendo o foco principal da aula; valoriza o conhecimento dos alunos; torna o processo de ensino-aprendizagem mais dinâmico e colaborativo.

Aprendi, também, que nas aulas de IFE não se usa livro didático e sim um material criado pelas próprias professoras. Quando produzi materiais para minhas coparticipações, percebi que era um exercício muito criativo e complexo. Gostaria que houvesse um espaço maior para a produção de materiais na faculdade (poderia ser uma disciplina optativa) porque é algo essencial nessa profissão. Me diverti fazendo o material para minha coparticipação na aula sobre perfumes na turma de Farmácia e também fiquei feliz quando ajudei a professora a elaborar uma prova para a turma de Bioquímica. Acredito que todo material tenha seu valor, mas me identifiquei com esse tipo de material do IFE de uma forma que não aconteceu com nenhuma outra metodologia/abordagem até então. Sobre as professoras, tive um relacionamento muito bom com elas.

Acompanhava a professora Carla nas quintas-feiras e a professora Maria nos sábados. Ambas são profissionais muito competentes e humanas, o que foi importante presenciar. Além de terem me ensinado bastante sobre o IFE e educação em geral, também me ofereceram apoio e carinho e fizeram eu me sentir acolhida.

Não tive um relacionamento tão próximo com os alunos quanto gostaria de ter tido, mas não acho que tenha sido um problema. Estava (e ainda estou) no começo da minha carreira e sei que tenho muito a melhorar. Ainda assim, os alunos foram simpáticos durante minhas coparticipações e fiquei emocionada com o apoio deles. 
Participei mais das aulas da turma de Farmácia, já que faria minha regência lá. Me esforcei bastante para fazer o material da regência porque fiz uma longa pesquisa, mas apesar de trabalhoso não foi um processo que fez com que eu me sentisse desconfortável ou nervosa. Como disse anteriormente, me identifiquei com a abordagem e as professoras, então apesar do nervosismo natural que a regência traz, consegui compreender o que precisava fazer e como fazer. No começo, me senti um pouco insegura em relação ao tema da aula (medicina tradicional e alternativa) e cheguei a pensar em pedir para trocá-lo. Mas achei que seria melhor para o meu desenvolvimento como professora encarar a situação como um desafio e assim consegui completar a preparação. A regência em si me deixou muito contente. Foi a primeira vez que eu dei uma aula completa e, de forma geral, ela correu bem. Tenho certeza que ter uma boa experiência na minha primeira aula foi um fator decisivo na minha escolha de seguir na profissão e, por isso, sinto muita gratidão pelas professoras, pelos alunos e pela escola. 


\section{Anexo 6-Conversas}

\section{Conversa 1}

\begin{tabular}{|c|c|c|}
\hline 1 & Carla & e aí gente...queria saber assim as primeiras impressões \\
\hline 2 & & que vocês tiveram... assim do estágio desde u: (.) a reunião que \\
\hline 3 & & nós fizemos né? para receber os estagiários (.) o que \\
\hline 4 & & vocês estão achando da escola...? \\
\hline 5 & Enzo & pode falar, elis. ((elis ri)) não tem problema não... sempre eu \\
\hline 6 & & que começo ... ela vai editar isso depois no áudio (.) \\
\hline 7 & & ( (enzo e elis rindo)) melhores momentos \\
\hline 8 & Carla & tanto faz, gente \\
\hline 9 & Enzo & eu gostei... achei bem legal (.) o que mais me chamou a atenção \\
\hline 10 & & foi a questão do uso de inglês na sala de aula porque... é (.) foi \\
\hline 11 & & até uma discussão que eu tive com a professora sobre a profissão \\
\hline 12 & & docente (.) que no Brasil o aluno só aprende inglês em curso de \\
\hline 13 & & inglês (.) infelizmente nós temos essa concepção né (.) parece que \\
\hline 14 & & o professor de inglês ... ele não está capacitado dentro da escola \\
\hline 15 & & de ensinar inglês para o aluno (.) se você quiser ensinar $e$ \\
\hline 16 & & aprender inglês você vai pro curso de inglês porque no curso de \\
\hline 17 & & inglês que tem profissionais suficientemente capacitados para \\
\hline 18 & & ensinar só que o mec não reconhece o curso de inglês como uma \\
\hline 19 & & escola então o curso de inglês não precisa contratar um professor \\
\hline 20 & & de inglês... apenas um instrutor de inglês (.) então como é que é? \\
\hline 21 & & tipo a gente estuda na faculdade ... fica quatro cinco seis anos... \\
\hline 22 & & deus sabe quanto tempo a gente fica estudando...para um simples \\
\hline 23 & & instrutor (.) não desmerecendo....mas não tem a questão \\
\hline 24 & & pedagógica (.) não tem a questão de língua que nós temos... um \\
\hline 25 & & instrutor que fez cinco anos de curso de inglês... chegar e dar \\
\hline 26 & & aula e ter o título pela sociedade de professor de inglês \\
\hline 27 & Elis & hurrum aquele [que ensina $\circ$ inglês] \\
\hline 28 & Enzo & [aquele que tem realmente a formação] \\
\hline 29 & & para ensinar inglês com conhecimento de inglês (.) quando tá na \\
\hline 30 & & escola tipo não ensina inglês na escola ...parece que é uma matéria \\
\hline 31 & & pra constar (.)mas quando eu cheguei aqui eu vi que não \\
\hline 32 & & o aluno ele pode aprender inglês sim na escola... porque aqui eles \\
\hline 33 & & aprendem inglês na escola (.) para fins específicos \\
\hline 34 & & e: é bem difícil o fins específicos também (.) achei isso BEM legal \\
\hline 35 & & só o ambiente de língua inglesa dentro de uma sala de aula \\
\hline 36 & & numa ESCOLA (.) pra mim foi um choque (.) eu não tava acostumado \\
\hline 37 & & porque eu estudei na faetec... e lá era inglês específico também \\
\hline 38 & & e a aula tinha um material em inglês... um material específico \\
\hline 39 & & para cada área... mas a aula não era em inglês \\
\hline 40 & & a aula era em português... pra mim também isso já foi um choque \\
\hline 41 & & com perspectiva positiva \\
\hline 42 & Elis & $\operatorname{sim}$ \\
\hline 43 & Carla & é legal porque assim (.) acredito que eles sentem \\
\hline 44 & Elis & que é uma aula de inglês mesmo né \\
\hline 45 & Carla & eles não ficam com medo porque tem um momento \\
\hline 46 & & de conscientização (.) e eu também falo português com eles \\
\hline 47 & Enzo & mas aí tem a questão do nível também... né? \\
\hline 48 & Carla & mas o português é uma ferramenta (.) não só aqui no básico \\
\hline 49 & Carla & e você? ((viro para Elis)) quais são suas impressões? \\
\hline 50 & Elis & foi bom ele ter falado do curso de inglês porque eu não fiz curso... \\
\hline 51 & & e eu acho que muitos deles aqui talvez não tenham feito... então \\
\hline 52 & & achei que poderia ser uma forma em que eu poderia me \\
\hline 53 & & relacionar com eles ... mostrar pra eles que é possível você \\
\hline 54 & & aprender inglês sem ir pro curso (.) não não é uma... eles podem \\
\hline 55 & & também... né fazer i:sso (.) \\
\hline 56 & Elis & e eu também gostei de a gente não focar \\
\hline 57 & & muito na gramática... não ter um livro como tem no curso de \\
\hline 58 & & inglês... porque fica uma coisa mais livre assim de se trabalhar \\
\hline
\end{tabular}




\begin{tabular}{|c|c|c|}
\hline 59 & Carla & o que vocês acham de nós fazermos uma apostila pra seguir? \\
\hline 60 & & vocês acham que seria possível aqui? apostila? \\
\hline 61 & Elis & poderia até ser possível... mas não sei se seria a melhor opção \\
\hline 62 & & porque tem as notícias que a gente pode sempre estar utilizando \\
\hline 63 & & com um livro isso não seria tão possível \\
\hline 64 & Enzo & tem umas partes positivas e outras negativas né \\
\hline 65 & Carla & exatamente (.) às vezes é até poderia se dizer talvez um fardo muito \\
\hline 66 & & grande de ter que preparar tu:do \\
\hline 67 & Enzo & você se prende também (.) eu geralmente fico meu final de semana \\
\hline 68 & & inteirinho preparando aula... isso porque já passei a semana \\
\hline 69 & & inteirinha pensando na aula pra chegar sábado sentar e fazer... \\
\hline 70 & & mas agora tem a questão que o livro prende muito também né (.) \\
\hline 71 & & mas não é VoCÊ que prende (.) às vezes você quer ir além e \\
\hline 72 & & substituir algo do livro e o aluno não quer...ele comprou o livro e \\
\hline 73 & & ele quer usar o livro \\
\hline 74 & Elis & tem isso também... eles aqui não são tão presos ao livro \\
\hline 75 & Carla & não... não aqui não tem livro... simplesmente não tem... \\
\hline 76 & & além do fato ... assim ... aqui é inglês para fins específicos... \\
\hline 77 & & que livro que vai dar conta de meio ambiente alimentos \\
\hline 78 & & [biotecnologia farmácia química?] \\
\hline 79 & Elis & [teria que ser um livro pra cada curso] \\
\hline 80 & Enzo & lá na faetec tinha uma apostila pra cada série e cada curso \\
\hline 81 & & só que honestamente não funcionava muito não ... não era inglês \\
\hline 82 & & específico \\
\hline 83 & Carla & é complicado né (.) aqui por exemplo ... na química foram \\
\hline 84 & & admitidos novos elementos, né... então a gente não usa o mesmo \\
\hline 85 & & texto para a tabela periódica ... a gente prefere usar outro texto \\
\hline 86 & & todo período ... não digo nem todo ano ... todo PERÍODO o material \\
\hline 87 & & é renovado (.) não tanto quanto a gente gostaria porque é \\
\hline 88 & & impossível... humanamente impossível (.) mas é até as necessidades \\
\hline 89 & & deles mudam também... quando eu entrei aqui a necessidade não \\
\hline 90 & & era tão grande da modalidade oral ... hoje em dia pede-se bastante \\
\hline 91 & & pra eles fazerem entrevistas em outras instituições por exemplo e \\
\hline 92 & & a gente prepara eles pra entrevista em inglês (.) quer dizer mudou \\
\hline 93 & Carla & quando a gente se conheceu, perguntei sobre suas expectativas \\
\hline 94 & & vocês lembram? \\
\hline 95 & Enzo & ((rindo)) já sumi com isso na minha vida (.) tento não criar \\
\hline 96 & & expectativas né (.) mas se eu comparar com o outro estágio em \\
\hline 97 & & inglês na rede estadual por exemplo (.) estou gostando \\
\hline 98 & Carla & o negócio é assim ... a minha... porque você já trabalha \\
\hline 99 & & né? ( (me dirigindo ao Enzo, que confirma gestualmente que sim)) \\
\hline 100 & & você também já trabalha? ( (minha pergunta direcionada a Elis)) \\
\hline 101 & Elis & eu não (.) pra mim pra mim é TUDO diferente... pra mim é tudo \\
\hline 102 & & novo... tudo eu estou fazendo isso aqui pela primeira vez (.) e eu \\
\hline 103 & & não sabia que fazer estágio em uma escola técnica era uma \\
\hline 104 & & possibilidade ... assim eu achava que eu ia pra uma escola: \\
\hline 105 & & comu:m... aí é tudo muito novo (.) essa questão de produzir o \\
\hline 106 & & material... não ter que seguir um livro \\
\hline 107 & Carla & você está fazendo português aqui também, não? \\
\hline 108 & Elis & não... só estou fazendo inglês \\
\hline 109 & Carla & e português você vai fazer depois \\
\hline 110 & Elis & pretendo... pretendo não... tem que fazer ( (Elis e Enzo riem) ) \\
\hline 111 & Enzo & é...tem que fazer ( (Elis e Enzo riem))... tem minha vaga lá... só \\
\hline 112 & & esqueceram de avisar ao coordenador ( (Elis e Enzo rindo muito)) \\
\hline 113 & Carla & porque pra mim vocês estavam tentando [fazer em outra escola] \\
\hline 114 & Elis & [a gente] \\
\hline 115 & Carla & então tem que conversar com o professor daqui depois \\
\hline 116 & Elis & a gente tá tentando mas não tá conseguindo não (.) \\
\hline 117 & & mas então o: o estágio aqui eu estou achando que está sendo bom \\
\hline 118 & & ... assim (.) você e a Maria são bem simpá:ticas... são... \\
\hline 119 & & as turmas são recepti:vas né... [os alunos eles] \\
\hline 120 & Carla & [é eles são] \\
\hline
\end{tabular}




\begin{tabular}{|c|c|c|c|}
\hline \multirow{2}{*}{\multicolumn{4}{|c|}{$\begin{array}{l}\text { é ... os alunos eles FA:lam com você assim... eles não ficam (.) } \\
\text { distan:tes... então é bom }\end{array}$}} \\
\hline & & & \\
\hline & 123 & Carla & é legal ... também é assim o grupo de estagiários que a gente tem \\
\hline & 124 & & aqui nesses últimos semestres também é um grupo... são muito \\
\hline & 125 & & interessados ... acho muito rico pra gente (.) mesmo você dizendo \\
\hline & 126 & & ((virando para Elis)) "não tenho experiência de sala de aula... " \\
\hline & 127 & & mas você traz outras experiências ... ( (virando para Enzo) ) você faz \\
\hline & 128 & & outras coisas na sua sala de aula e a gente pode compartilhar ... \\
\hline & 129 & & para os alunos também o fato de ter mais professores dentro da \\
\hline & 130 & & sala (.) apesar de ficarem com vergonha né é: com o tempo passa \\
\hline & 131 & & a ser mais normal (.) essa turma específica ... que é a bm $131 . .$. \\
\hline & 132 & & eles não tiveram estagiários na sala ainda... Outros estagiários ... \\
\hline & 133 & & nos períodos passados ... mas se vocês repararem... tem algumas \\
\hline & 134 & & turmas que já estão mais [acostumadas] \\
\hline & 135 & Elis & {$[\mathrm{sim}]$} \\
\hline & 136 & & $\left(5^{\prime \prime}\right)$ \\
\hline & 137 & Carla & de qualquer forma (.) o que eu realmente sinto é que o estágio \\
\hline & 138 & & em si pode ser proveitoso pra gente conversar sobre o que nós \\
\hline & 139 & & estamos fazendo também... o estágio é nosso... então eu queria \\
\hline & 140 & & que vocês falassem mais o que acham... dessem suas sugestõ:es \\
\hline & 141 & & sobre o que a gente pode fazer pra (.) igual a gente tava \\
\hline & 142 & & conversando hoje né... como está hoje (.) o material é esse... mas \\
\hline & 143 & & o que a gente pode fazer pra melhorar... renovar... a adequar à \\
\hline & 144 & & turma (.) pra gente pensar junto ... estou oferecendo a turma ... \\
\hline & 145 & & ela é de vocês também (.) as turmas são nossas ... o que vamos \\
\hline & 146 & & fazer JUNtos com elas? (.) as turmas da Maria também no sábado \\
\hline & 147 & Elis & eu acho bom que vocês dão esse espaço pra gente pra gente \\
\hline$\sum_{\alpha}$ & 148 & & dar sugestõ:es também... pra falar lá na frente e tal ... pra \\
\hline ֻ & 149 & & que não tenho experiência é: : : : \\
\hline 4 & 150 & Carla & mas daqui a pouco você está tirando isso de letra \\
\hline & 151 & Enzo & está mesmo... a minha primeira aula foi assim ó... \\
\hline 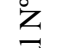 & 152 & & ( (Enzo se treme todo e nós três rimos) ) estou falando sério... \\
\hline. & 153 & & ((rindo) ) minha primeira aula foi terrível terrível terrível \\
\hline$\stackrel{10}{a}$ & 154 & Elis & é um alívio que... quando eu chegar em uma esco:la eu já vou ter \\
\hline (2) & 155 & & essa experiência (.) e como eu falei na outra aula eu espero \\
\hline ฮु & 156 & & conseguir dar aula assim numa escola assim... em uma escola \\
\hline$\stackrel{g}{g}$ & 157 & & técnica (.) eu gostei mais do que ficar falando sobre gramática (.) \\
\hline & 158 & & não sou muito fã de gramática \\
\hline
\end{tabular}

\section{Conversa 2}

\begin{tabular}{|r|c|l|}
\hline 1 & Carla & como é que você se sentiu da primeira vez? du: \\
\hline 2 & Elis & >é que da primeira vez eu não tava tão nervosa< eu fiz o material mas \\
\hline 3 & & eu não sabia que eu ia... conduzir \\
\hline 4 & Carla & Hurrum \\
\hline 5 & Elis & acho que acho que era é: foi sexta feira que ela me avisou \\
\hline 6 & & tipo "amanhã você vai conduzir a atividade tá bem?" aí eu é \\
\hline 7 & & que da minha... nem deu muito tempo de me desesperar muito \\
\hline 8 & & [fui fazendo] ( (fala rindo) ) . \\
\hline 9 & Ana & [dá um pânico, né] \\
\hline 10 & Enzo & é... é muito: \\
\hline 11 & Carla & deu nervoso no início... mas depois foi né... ou não? \\
\hline 12 & Elis & é: : eu não sei... eu sempre tinha a impressão assi:m "fui tão mal \\
\hline 13 & Elis & mas os alunos gostaram" (.) E ELES GOSTARAM \\
\hline 14 & Carla & hurrum \\
\hline 15 & Elis & então... . são eles que dão segurança... você fica nervoso... ao mesmo \\
\hline 16 & & tempo você se sente EELIZ né ... de você ter conseguido fazer \\
\hline
\end{tabular}

\section{Conversa 3}

1 Carla 1 e aí... o que você tá achando até agora? 


\begin{tabular}{|c|c|c|}
\hline 2 & Léa & estou sentindo muita diferença \\
\hline 3 & Carla & em quê? \\
\hline 4 & Léa & na verdade insegurança porque: : : eu tenho a sensação de que \\
\hline 5 & & eles sabem mais do que eu da matéria e isso me deixa insegura \\
\hline 6 & Carla & é mais quanto ao vocabulário né? \\
\hline 7 & Léa & eu acho que talvez vocabulário a gente consiga dar conta... mas \\
\hline 8 & & aí...como funciona essa palavra específica? não sei \\
\hline 9 & Carla & [entendi] \\
\hline 10 & Enzo & [é é o uso] daquela palavra... eu sei que eles aqui são química \\
\hline 11 & & (.) eles sabem o contexto mas não estão entendendo $\circ$ texto ... \\
\hline 12 & & quando me perguntam uma palavra por exemplo \\
\hline 13 & & eu digo "eu >não sei<... pode ser isso isso ou talvez isso...mas \\
\hline 14 & & pelo que entendi é isso ... tem isso no laboratório de vocês?" aí \\
\hline 15 & & eles "tem um negócio mais ou menos assim assim assim" "e eu \\
\hline 16 & & "a: então deve ser isso"... não tem problema nenhum \\
\hline 17 & Elis & é... NÃO TEM (.) eles nos ajudam \\
\hline 18 & Léa & mas e na prova de aula? \\
\hline 19 & Carla & calma... conversa com a gente... você pode tentar escolher \\
\hline 20 & & um tema que fique mais no meio do caminho (.) acho que você \\
\hline 21 & & está com mais experiência em fazer atividades, né elis? \\
\hline 22 & Elis & é... até tô preparando coisas pra sábado agora... mas é isso aí... \\
\hline 23 & Carla & é de que o material? \\
\hline 24 & Elis & farmácia \\
\hline 25 & Carla & eu adoro aquela turma de farmácia \\
\hline 26 & Elis & é eles são muito legais \\
\hline 27 & & a gente acha que porque é de humanas não vai gostar \\
\hline 28 & & de nada aqui, mas eu acabei me apaixonando \\
\hline 29 & & eu acho muito legal (.) é melhor também porque a gente não tem \\
\hline 30 & & que fazer prova ( (rindo)) na escola tinha química e física e tinha \\
\hline 31 & & que fazer prova aí era chato... \\
\hline 32 & Enzo & é: $($ (rindo) $)$ \\
\hline 33 & Elis & aqui não... aqui parece assim... curiosidade de uma revista \\
\hline 34 & Carla & hurrum \\
\hline 35 & Elis & não fica pesado \\
\hline 36 & Carla & conta da aula de sábado \\
\hline 37 & Elis & é de tipos de medicamento (.) fui pesquisando o assunto \\
\hline 38 & & escolhendo os textos...tô fazendo atividades e tentando ligar \\
\hline 39 & & tudo ainda... com a AJUDA da professora \\
\hline 40 & Carla & e ((virando para léa)) se precisar... pode contar com a \\
\hline 41 & & nossa ajuda também (.) pode perguntar... ligar... mandar \\
\hline 42 & & whatsapp ... é o que a gente faz normalmente mesmo \\
\hline 43 & Elis & é... a gente faz junto (.) e lembra Léa ... \\
\hline 44 & & do que eu tava te falando... nesse sábado vai ter oficina \\
\hline 45 & & sobre materiais... acho que é legal você vir... \\
\hline 46 & Carla & i:sso... exatamente... tenho que até mandar esse e-mail pra vocês \\
\hline 47 & & é com um professor que trabalhou muito tempo aqui e \\
\hline 48 & & ele vai falar sobre a elaboração de materiais de inglês \\
\hline 49 & & para fins Específicos (.) muito bom se você puder vir \\
\hline 50 & Elis & e tem o minicurso também \\
\hline 51 & Léa & o que tem que fazer pra vir? \\
\hline 52 & Carla & vou mandar AGORA para vocês as informações sobre a oficina \\
\hline 53 & & e como se inscrever no minicurso (.) foi muito bom lembrar isso \\
\hline
\end{tabular}

\begin{tabular}{|l|l|l|}
\hline 1 & Carla & mas como é que vocês fazem o material você e maria? vocês começam \\
\hline 2 & & do zero e aí escolhem... escolhem... \\
\hline 3 & Elis & a: a gente pesquisa textos na internet, baixa vídeos \\
\hline 4 & & às vezes a gente até tem uma ideia que muda tudo \\
\hline 5 & & tanto que na aula de meio-ambiente >tava falando pra ela< a gente \\
\hline 6 & & tava na dúvida pra fazer alguma coisa pra turma de meio-ambiente \\
\hline 8 & & e ela ia falar sobre outro assunto e aí ela me deixou trocar \\
\hline 8 & & porque eu falei "porque que a gente não fala sobre outra coisa?" \\
\hline
\end{tabular}




\begin{tabular}{|r|l|l|}
\hline 9 & Carla & hurrum \\
\hline 10 & Elis & e aí virou uma aula completamente diferente muito mais voltada pra \\
\hline 11 & & nossa realidade praquela turma ... a especificidade \\
\hline 12 & Carla & si:m mas com os temas... lidando com os temas em si é: como é que \\
\hline 13 & & como é ...vocês... como é que vocês estão fazendo assim é: com \\
\hline 14 & & o foco? fica mais no vocabulário? ou mas em reading strategies o:u \\
\hline 15 & Elis & a gente faz um pouquinho de tudo assim ... procura não focar demais \\
\hline 16 & & em uma coisa em um aspecto (.) a gente tenta fazer é: aí tenta achar \\
\hline 17 & & algum motivo na internet com o tema e vocabulário que é importante \\
\hline 18 & & pra eles (.) algumas palavras novas \\
\hline 19 & Carla & e aí você faz atividade com vocabulário ou não? \\
\hline 20 & Elis & geralmente fica: (.) por exemplo eu fiz três atividades... aí uma \\
\hline 21 & & vai ser de discussão sobre o tema outra do gênero outra sobre o \\
\hline 22 & & vocabulário específico da área deles... perguntas diferentes assim \\
\hline 23 & & trabalha todos esses aspectos \\
\hline
\end{tabular}

\section{Conversa 4}

\begin{tabular}{|c|c|c|}
\hline 1 & Elis & porque eu botei tudo ... o que eu imaqinava.... o que eu esperava... \\
\hline 2 & & as expectativas... no sentido do que eu queria que acontecesse (.) \\
\hline 3 & & não do que eu achei que ia acontecer ... aí eu botei por exemplo \\
\hline 4 & & "espero aproveitar ao máximo a minha experiência e ter um bom \\
\hline 5 & & convívio com os alunos e professores com os quais eu tiver contato \\
\hline 6 & & e auxiliar os alunos no que precisarem" ((lendo)) aí eu achava que \\
\hline 7 & & eu ia ter muito contato com os alunos e não tanto com vocês ... \\
\hline 8 & & e eu acho que no final das contas eu acabei me envolvendo \\
\hline 9 & & mais com vocês do que com os alunos \\
\hline 10 & Maria & é verdade \\
\hline 11 & Elis & e assim... eu acho que no sábado eu até consegui um pouquinho mais \\
\hline 12 & & mas na quinta feira eu não consegui me enturmar tanto \\
\hline 13 & & com a turma ... eu queria MAIS... \\
\hline 14 & Carla & hurrum \\
\hline 15 & Elis & [principalmente] a de meio-ambiente... [a última] \\
\hline 16 & Fábio & [eu também] [eles são muito legais] \\
\hline 17 & Elis & eles são muito legais (.) então... mas eu eu não sei assim de quais \\
\hline 18 & & formas ... porque a gente fica meio sem jeito de se meter \\
\hline 19 & Lara & é mesmo \\
\hline 20 & Elis & até também pra não tirar ...espaço... o espaço de vocês como \\
\hline 21 & & professores (.) ficar... "a: ... eu que sou a professora agora"... \\
\hline 22 & & não vou fazer isso né? então... a gente fica ali num... parece que a \\
\hline 23 & & gente fica meio sem lugar eu acho \\
\hline 24 & & a gente não é aluno e também não é professor... entã:o \\
\hline 25 & Fábio & não tem lugar \\
\hline 26 & Elis & onde que a gente se encaixa aqui? \\
\hline 28 & Hugo & acho que assim, no início também é uma coisa que eu não sei \\
\hline 30 & & porque ... o que eu percebi dentro do estágio \\
\hline 31 & & é que vocês fazem sim um esforço pra trazer a gente pra a sala \\
\hline 32 & & de aula ... pra fazer a gente participar mas eu acho que \\
\hline 33 & & no início a gente se sente um pouco assim... INCAPAZ \\
\hline 34 & Lara & [é: ] \\
\hline 35 & Elis & {$[\mathrm{si}: \mathrm{m}]$} \\
\hline 36 & Hugo & eu me senti um pouco incapaz assim de realmente assim é \\
\hline 37 & & porque eu cheguei aqui com uma visão bem geral que coloquei \\
\hline 38 & & das respostas do esp ... peguei inglês para fins específicos \\
\hline 39 & & e desenvolvi numa frase... foi uma coisa bem geral mesmo... tava \\
\hline 40 & & com o entusiasmo de aprender realmente assim como que era o esp \\
\hline 41 & & eu lembro que não sabia... coloquei aqui como o professor utiliza \\
\hline 42 & & o material né? ((todos riem)) minha expectativa pra material aí \\
\hline
\end{tabular}




\begin{tabular}{|l|l|l|}
\hline 43 & & eu coloquei livro didático e material extra ( (todos rindo muito) ) \\
\hline 44 & & ou seja eu achava que tinha livro didático né? \\
\hline 45 & & então eu não tinha noção ainda das coisas \\
\hline
\end{tabular}

\begin{tabular}{|r|l|l|}
\hline 1 & Carla & uma coisa que eu queria fazer era chamar os estagiários \\
\hline 2 & & de lá de trás (.) isso me incomoda um pouco .. o o que vocês \\
\hline 3 & & acham assim? vocês acham que isso atrapalharia vocês? \\
\hline 4 & Elis & eu acho que, dependendo da turma fica melhor >porque eu acho \\
\hline 6 & & que depende da turma< naquela turma por exemplo \\
\hline 7 & & de quinta-feira a primeira que é muito cheia \\
\hline 8 & & a gente ficar ali atrás é muito bom porque eu acho que \\
\hline 9 & & os alunos tem muito aluno inseguro ali atrás, entendeu? \\
\hline 10 & & "a: não sei inglês ... assim" \\
\hline 11 & & que é estagiário ... porque ficam com medo \\
\hline 12 & & eu tô falando no sentido de que eu acho que \\
\hline 13 & & a gente sentar ali atrás pode ajudar... é estratégico \\
\hline 14 & & sábado por exemplo... isso já não é bom ... é mais fácil \\
\hline 15 & & fazer uma roda e ficar no meio deles mas em uma turma grande \\
\hline 16 & & a bml31 tem dezoito alunos naquela sala alí né? \\
\hline 17 & & aí fica assim né ... fica be:m \\
\hline 18 & Carla & é fica bem apertado ... eu não tinha pensado nisso não porque eu \\
\hline 19 & & ficava assim "gente... será que eu posso pedir pra vir aqui \\
\hline 20 & & pra frente?" talvez se vocês não sentarem JuNtos \\
\hline 21 & Elis & é bom espalhar que fica melhor \\
\hline 22 & Carla & [isso espalhar um pouco né?] \\
\hline 23 & Maria & [é espalhar... eu também não gostava] de todos juntos não \\
\hline 24 & Carla & não me incomodo ( (inaudível) ) \\
\hline 25 & Maria & não... porque tinha dia que tinha muitos estagiários \\
\hline 26 & & se não espalhar fica uma turma de estagiários e outra de alunos \\
\hline
\end{tabular}

\section{Conversa 5}

\begin{tabular}{|r|l|l|}
\hline 1 & Carla & demorou muito? \\
\hline 2 & Fábio & puxa... tamos tensos... \\
\hline 3 & Carla & ( (todos rindo) ) podem entrar (.) eu vou continuar gravando tá? como eu \\
\hline 4 & & falei para vocês antes... tô vendo que tão com o olho assim... que foi? \\
\hline 6 & Elis & ( (rindo) ) a gente >ficou com medo< \\
\hline 7 & Carla & mas por quê? \\
\hline 8 & Carla & é então é: vamos começar com a elis... pode ser? o que vocês preferem? \\
\hline 9 & Elis & [pode ser] \\
\hline 10 & Fábio & [pode ser] \\
\hline 11 & Carla & ou pelo último que tá mais fresco na mente? \\
\hline 12 & Flávia & acho que pode começar por ela \\
\hline 13 & Carla & é? então elis ... o que você achou da sua aula? \\
\hline 14 & Elis & eu achei que foi boa assim eu achei que eles gostaram e: eu achei que \\
\hline 15 & & eu consegui passar o: : >passar não< (4) não sei o verbo que eu \\
\hline 16 & & uso ( (rindo) )... que verbo eu uso? >acho que ficou claro< eles acho que \\
\hline 17 & & já sabiam (.) o que que é fitoterapia alopatia homeopatia e tal... \\
\hline 18 & & achei que a discussão no final que foi bem (.) foi boa... teve alguns \\
\hline 19 & & erros ali na hora que eu esqueci de distribuir o texto os textos pra \\
\hline 20 & & todo mundo ficou um pouco confuso ali na hora... é: também na hora do \\
\hline 21 & & exercício... >no texto da marijuana< eu esqueci de trocar a ordem da \\
\hline 22 & & das informações no texto >mas acho até que foi<... Bom assim >eles \\
\hline 23 & & acharem que tinha pegadinha< aí ficaram meio assim ( (rindo) ) \\
\hline 24 & Carla & é: \\
\hline
\end{tabular}

\begin{tabular}{|l|l|l|}
\hline 1 & Flávia & quanto que você se daria? \\
\hline 2 & Elis & a: >tô com medo de me dar uma nota mais alta do que eu mereço< (9) \\
\hline 3 & Fabio & 'foi muito bom elis ${ }^{\circ}$ \\
\hline
\end{tabular}




\begin{tabular}{|r|l|l|}
\hline 4 & Elis & não sei...ai ai ai \\
\hline 5 & & eu acho que não seria dez... mas acho que abaixo dos nove também \\
\hline 6 & & num... não seria... alguma coisa por aí (6) \\
\hline 7 & & falando sobre essa aula ou sobre o estágio todo? \\
\hline 8 & Carla & não... só sobre a aula (8) \\
\hline 9 & Flávia & bom... eu queria [fazer uns comentários] \\
\hline 10 & Elis & \multicolumn{1}{c|}{ [A QUESTÃO] do tempo... não DEU muito pra eu seguir } \\
\hline 11 & & exatamente o que tava aí porque >não dá para a gente prever como eles \\
\hline 12 & & vão reagir e o primeiro passo demorou mais tempo do que eu pensei que \\
\hline 13 & & fosse demorar< \\
\hline 14 & Flávia & então ... posso pegar esse gancho? \\
\hline 15 & Elis & hurrum \\
\hline
\end{tabular}

\begin{tabular}{|r|l|l|}
\hline 1 & Elis & eu ia se-parar mais mas depois eu pensei pra mim "eu vou acabar me \\
\hline 2 & & enrolando mais" eu não sei \\
\hline 3 & Flávia & eu acho que [podia ajudar] \\
\hline 4 & Elis & [porque como eu disse pra você o objetivo seria o mesmo] \\
\hline 5 & Flávia & pois é... eu não sei ... não sei mesmo porque... você tá lidando com \\
\hline 6 & & vídeo e você tá lidando com texto... são dois tipos de materiais \\
\hline 7 & & diferentes ... vamos botar nos termos que a gente vê na nossa aula \\
\hline 8 & & são dois textos situados sociohistoricamente e isso faltou aqui tá \\
\hline 9 & & ... que fazem circular ideologias ... que ideologias são essas... você \\
\hline 10 & & vamo botar isso aí... e acho que você subestimou o quão interessante \\
\hline 11 & & poderia ser a temática \\
\hline
\end{tabular}

\begin{tabular}{|c|c|c|}
\hline 1 & Carla & você se saiu muito bem... você tava nervosa lá fora mas \\
\hline 2 & Elis & mas eu ... foi mais tranquilo do que eu pensei que ia ser ... assim \\
\hline 3 & & do que eu imaginava \\
\hline 4 & Carla & você tava esperando [ter mais o que] \\
\hline 5 & Elis & [assim... eu não] fiquei gagueja:ndo= \\
\hline 6 & Carla & nã::o \\
\hline 7 & Flávia & não mesmo \\
\hline 8 & Elis & =eu não esqueci o que eu ia fala:r... é: eu até poderia ter feito \\
\hline 9 & & uma instrução melhorzinha mas assim \\
\hline 10 & Carla & teve coisa que você apontou quando você foi analisar a aula que eu \\
\hline 11 & & não percebi (.) você disse "eu errei não sei o quê" não vi \\
\hline 12 & & ( (todos riem) ) não chamou a atenção= \\
\hline 13 & Flávia & {$\left[{ }^{\circ}\right.$ não....não $]$} \\
\hline 14 & Carla & talvez você tenha se preocupado com algumas coisas enquanto você tava \\
\hline 15 & & lá fora esperando pensando que talvez a gente fosse falar disso \\
\hline 16 & & a: e outra co:isa que eu não sei se e acho que a flavia concorda mas \\
\hline 17 & & não sei se ela já comentou... acho que não... é que o planejamento \\
\hline 18 & & tá ali como base pra vocês mas é a tua turma que vai dar o tom \\
\hline 19 & & na verdade ... eles vão falar coisas que não estavam planejadas né \\
\hline 20 & & como ela tava dizendo a garota falou earth né \\
\hline 21 & Fábio & é: aí você conseguiu aproveitar aquela informação e foi \\
\hline 22 & Elis & É mesmo... tomei um outro caminho \\
\hline
\end{tabular}




\section{Anexo 7 - Vídeo}

1 meu nome é Elis e eu sou (.) aluna da faculdade de letras UFRJ

2 faço português inglês licenciatura... e fiz o meu estágio

3 supervisionado na escola técnica ... no IFRJ e bom

4 pra mim a experiência do estágio foi crucial para a minha formação

5 porque: foi o meu primeiro estágio na área du: na área da docência

6 então pra mim foi quase que um teste pessoal e profissional assim

7 será que isso é uma coisa que eu consigo fazer?

8 será que eu me VEjo no futuro fazendo isso daqui pra frente?

9 e: é engraçado ... porque agora eu quero ser professora de IFE ( (rindo))

10 eu quero vir pra cá (.) claro que algum dia... ainda tenho que

11 trabalhar muito para chegar aqui porque também eu sei

12 que o professor nunca fica em uma coisa só >ele dá aula

13 em muitas escolas... em cursos... dá aula em universidades< então (.) vou

14 tentar chegar aqui... mas até lá né eu vou passar por outros caminhos

15 e:: : eu quero que essa disciplina ela fique na minha vida ... disciplina

16 eu digo tanto no sentido de conduta quanto no sentido da matéria da escola

17 que ela permaneça na minha vida porque é: eu aprendi muita coisa aqui

18 a: pela interação com os alunos e com as professoras

19 porque eu tinha certo receio de ... é: volTAR para o ambiente escolar

20 mas foi tranquilo foi muito bom foi divertido e também muito enriquecedor

21 é: : e também pela produção de material

22 em que eu pude aplicar muita coisa que eu aprendi

23 >durante a graduação< durante a VIda e também é: : onde eu pude aplicar

24 a pedagogia crítica que é pra mim e também para os alunos né ...

25 e: pela interdisciplinaridade que é uma coisa que eu não sei se eu poderia

26 ter feito em outras escolas... e que ...quando a gente faz a graduação você

27 acaba ficando um pouco preso na sua especialização ali (.)

28 então eu acabei me fechando no mundo das letras que é um mundo muito grande

29 (.) muito rico... mas eu acabei deixando as ciências um pouco de lado ...

30 >porque eu também tava cansada de fazer escola você faz a vida toda e

31 fica de saco cheio<(.) fiquei feliz de ter visto é:geografia de no:vo até

32 química de novo... biologia (.) e:...e: eu percebi que eu não precisava

33 ter deixado essas coisas de lado ...eu posso fazer letras e ainda não deixar

34 as exatas de lado (.) está tudo muito mais ligado do que a gente pensa

35 e é isso... foi um semestre MUITO bom... gostei muito do estágio

36 e: espero que seja uma boa experiência também pros que virão depois de mim. 


\title{
Anexo 8 - Autorização do Comitê de Ética em Pesquisa
}

\author{
Pontifícia Universidade Católica $_{\text {a }}$ \\ DO RIO DE JANEIRO
}

Câmara de Ética em Pesquisa da PUC - Rio

PARECER DA COMISSÃO DE ÉTICA EM PESQUISA DA PUC-RIO (2016-49)

A Câmara de Ética em Pesquisa da PUC-Rio foi constituída como uma Câmara específica do Conselho de Ensino e Pesquisa conforme decisão deste órgão colegiado com atribuição de avaliar projetos de pesquisa do ponto de vista de suas implicações éticas.

Identificação:

Título: Crenças sobre a Formação Docente: Avaliações do Estágio sob a Perspectiva da Linguística Sistêmico-Funcional (Departamento de Letras da PUC-Rio)

Autora: Carla Cristina de Souza (Doutoranda do Departamento de Letras da PUC-Rio)

Orientadora: Adriana Nogueira Accioly Nóbrega (Professora do Departamento de Letras da PUC-Rio)

Apresentação: Pesquisa qualitativa que visa analisar as crenças que informam as práticas dos professores envolvidos no estágio supervisionado de inglês, os papéis que tomam e os elementos avaliativos que constituem seus discursos sobre a formação docente e sobre o estágio. A pesquisa será realizada em um instituto de educação federal (ensino médio e técnico) e contará com a participação de professores-regentes de inglês, estagiários (licenciandos de Letras com dupla habilitação - Português e Inglês) e professores de Prática de Ensino. Serão utilizados no estudo memoriais de estágio, gravações em áudio, anotações em diários, avaliações de provas de aula e grupo de discussão com estagiários e professores.

A análise dos dados será baseada no entrelaçamento de teorias sociossemióticas, a Linguística Sistêmico Funcional e o Sistema de Avaliatividade, juntamente com pressupostos teóricos dos estudos de identidade e de crenças.

Aspectos éticos: $O$ projeto e o Termo de Consentimento Livre e Esclarecido apresentados estão de acordo com os princípios e valores do Marco Referencial, Estatuto e Regimento da Universidade no que se refere às responsabilidades de seu corpo docente e discente. $O$ Termo de Consentimento Livre e Esclarecido expõe com clareza os objetivos da pesquisa, os procedimentos a serem seguidos e a garantia do sigilo e da confidencialidade dos dados coletados e da identidade dos participantes. Informa sobre a possibilidade de interrupção na pesquisa sem aplicação de qualquer penalidade ou constrangimento.

Parecer: Considerando os elementos expostos acima somos de parecer Favorável à aprovação do projeto quanto aos princípios e critérios estabelecidos pela Comissão de Ética em Pesquisa da PUC-Rio.

Prof. José Ricarardo Bergmann

Presidente do Conselho de Ensino e Pesquisa da PUC-Rio

Rio de Janeiro, 28 de setembro de 2016.

Vice-Reitoria para Assuntos Acadêmicos Rua Marquês de São Vicente, 225 - Gávea - 22453-900. Rio de Janeiro - RJ - Tel. (021) 3527 1619 FAX (021) 35271132. 


\title{
Anexo 9 - Termo de Consentimento Livre e Esclarecido
}

\author{
Pontificia U Universidade C $_{\text {atólica }}$ \\ DO RIO DE JANEIRO \\ TERMO DE CONSENTIMENTO LIVRE E ESCLARECIDO

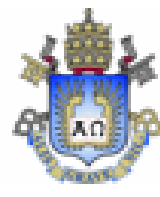

Este Termo tem por objetivo obter autorização para sua participação na pesquiga "Crenças sobre a formação docente: avaliações do estágio sob a perspectiva da Linguistica Sistêmico-Funcional", com pleno conhecimento dos procedimentos aos quais a mesma será submetida, com livre arbitrio e sem coação. O estudo está sendo realizado pela Pontificia Universidade Católica do Rio de Janeiro - PUC-Rio, pelo Programa de Pós-graduação em Estudos da Linguagem, e as informações contidas neste Termo são formecidas por Carla Cristina de Souza, pesquisadora principal, e por sua orientadora, Professora Doutora Adriana Nogueira Accioly Nóbrega (adriamanobrega@puc-rio.br - telefone: (21) 3527-1447).

OBJETIVO DO ESTUDO: O objetivo principal deste projeto é a busca de entendimentos sobre as crenças e práticas no estágio supervisionado no ensino de Inglês para Fins Especificos, com vistas a: (1) identificar algumas das crenças dos estagiários, professores-regentes, professora da prática de ensino e professora-pesquisadora sobre o estágio e sobre sua prática; (2) observar e analisar como os elementos avaliativos constroem as crenças e as identidades dos professores envolvidos no estágio; (3) investigar como as crenças sobre o estágio podem influenciar a coconstrução do conhecimento sobre a formação docente e as ações dos participantes; (4) analisar se e como as crenças e identidades são reelaboradas nas discussões em grupo a partir da análise dos elementos avaliativos.

JUSTIFICATIVA: Estudar o discurso dos professores no contexto educacional do estágio de forma reflexiva e coletiva pode contribuir para compreender melhor nossas crenças, práticas e contextos.

ALTERNATIVA PARA PARTICIPAÇÄO NO ESTUDO: Você tem o direito de não participar deste estudo. Estamos gerando informaçốes para compor o conpus de análise da tese de doutorado da pesquisadora responsável. A não participação do estudo não acarretará em prejuizo para sua vida profissional e/ou particular.

PROCEDIMENTO DO ESTUDO: Caso decida integrar este estudo, você participará de encontros com a pesquisadora responeável a fim de discutir sobre o tema proposto. Utilizaremos os dados gerados (gravaçōes em áudio, diários, memoriais e questionários elaborados pela pesquisadora) como parte do objeto de pesquisa.

GRAVAÇẢO EM ÄUDIO: Todos os encontros serão gravados em áudio, mas seu nome não será utilizado. As gravaçôes serão ouvidas por mim e pela pesquisadora orientadora e serão utilizadas somente para geração de dados. Se você não quiser ser gravado em áudio, você não poderá participar deste estudo.

RISCOS: Você pode achar que determinadas perguntas incomodam você, uma vez que as informações que geramos são sobre suas experiências e práticas profissionais. Assim sendo, você pode escolher não responder quaisquer perguntas e/ou temas propostos que o façam sentir incomodado. Você não correrá riscos diferentes dos que eventualmente podem vir a acontecer no seu cotidiano, visto que você não gerá exposto a situaçốes diferentes das que vivencia regularmente.

BENEFICIOS: Sua participação contribuirá para a reflexão sobre o estágio supervisionado na formação docente. Fazendo parte deste estudo, você fomecerá mais informaçōes sobre esta temática para, assim, contribuir para os estudos dentro da área de Formação de Professores de Línguas.

CONFIDENCIALIDADE: Os resultados da pesquiga serão apenas divulgados em eventos e publicações cientificas, e seu nome, ou de quaisquer participantes da pesquiga, não aparecerá nos dados gerados, bem como em nenhuma outra parte do trabalho ou em nenhuma publicação ou divulgação do estudo.

DÜVIDAS E RECLAMAÇÖES: As pesquisadoras estão disponiveis para responder a qualquer dúvida que você tenha. Caso seja necessário, contacte a pesquisadora responsável pelo telefone (21) _ _ _ ou pelo e-mail em qualquer fạe deste estudo. E importante dizer que você terá uma via deste consentimento è que você formecerá nome, endereço e telefone de contato apenas para que a equipe do estudo possa the contactar em caso de necessidade.

CONSENTIMENTO: Acredito ter sido suficientemente informado a respeito do estudo acima citado e que li, ou foram lidas para mim, todas as direções a serem seguidas para o desenvolvimento do trabalho proposto. Eu discuti com a pesquisadora Carla Cristina de Souza sobre a minha decisão em participar desta pesquisa e ficaram claros para mim os seus propósitos, o procedimento metodológico a ser realizado, as garantias de confidencialidade e os esclarecimentos permanentes. Também ficou claro que minha participação é isenta de despesas ou remuneração. Concordo voluntariamente em participar deste estudo e poderei retirar meu consentimento a qualquer momento, sem penalidades, prejuizo ou perda de qualquer beneficio que eu possa ter adquirido.

Rio de Janeiro, de de 